UNIVERSIDADE DE SÃO PAULO

INSTITUTO DE PSICOLOGIA

LUISA GUIRADO CARAMICOLI

O TRATAMENTO DE CRIANÇAS COM AUTISMO NA PERSPECTIVA DA ANÁLISE INSTITUCIONAL DO DISCURSO 


\section{O TRATAMENTO DE CRIANÇAS COM AUTISMO NA PERSPECTIVA DA ANÁLISE INSTITUCIONAL DO DISCURSO}

Texto apresentado ao Instituto de Psicologia da Universidade de São Paulo, como parte dos requisitos para obtenção do título de Doutora em Psicologia.

Área de Concentração: Psicologia Escolar e do Desenvolvimento Humano

Orientador: Prof. Dr. Livre Docente Rogério Lerner 
AUTORIZO A REPRODUÇÃO E DIVULGAÇÃO TOTAL OU PARCIAL DESTE TRABALHO, POR QUALQUER MEIO CONVENCIONAL OU ELETRÔNICO,

PARA FINS DE ESTUDO E PESQUISA, DESDE QUE CITADA A FONTE.

Catalogação na publicação

Biblioteca Dante Moreira Leite

Instituto de Psicologia da Universidade de São Paulo

Dados fornecidos pelo(a) autor(a)

\section{Guirado Caramicoli, Luisa}

O tratamento de crianças com autismo na perspectiva da Análise Institucional do Discurso / Luisa Guirado Caramicoli; orientador Rogério Lerner. -- São Paulo, 2021.

$169 \mathrm{f}$.

Tese (Doutorado - Programa de Pós-Graduação em Psicologia Escolar e do Desenvolvimento Humano) -- Instituto de Psicologia, Universidade de São Paulo, 2021.

1. Transtorno do espectro autista. 2. Análise Institucional do Discurso. 3. Analítica da Subjetividade. 4. Desenvolvimento Infantil. I. Lerner, Rogério, orient. II. Título. 
Nome: Luisa Guirado Caramicoli

Título: O tratamento de crianças com autismo na perspectiva da Análise Institucional do Discurso

Tese apresentada ao Programa de Pós-Graduação em Psicologia Escolar e do Desenvolvimento Humano do Instituto de Psicologia da Universidade de São Paulo para obtenção do título de Doutora em Psicologia.

Aprovado em:

\section{Banca Examinadora}

Orientador: Prof. Dr.

Instituição: Assinatura:

Prof. Dr. Instituição:

Julgamento: Assinatura:

Prof. Dr. Instituição:

Julgamento: Assinatura:

Prof. Dr. Instituição:

Julgamento: Assinatura:

Prof. Dr. Instituição:

Julgamento: Assinatura:

Prof. Dr. Instituição:

Julgamento: Assinatura: 
À Marlene Guirado,

por quem sou.

À Lis,

para quem sou. 


\section{AGRADECIMENTOS}

À Universidade de São Paulo e ao Instituto de Psicologia.

Ao professor livre docente e pesquisador Rogério Lerner, pela interlocução, atenção, disponibilidade e orientação de sempre.

Ao professor Lino de Macedo pelas conversas e trocas sempre muito instigadoras em busca de novos conhecimentos, e pela participação na banca de qualificação.

À professora Ana Paula Ramos, pela participação na banca de qualificação.

À banca examinadora pela leitura, atenção, participação e discussão sobre meu trabalho.

À Marlene Guirado, professora livre-docente, criadora do método da Análise Institucional do Discurso, pelas inúmeras conversas e discussões sobre esta Tese, pela disponibilidade acadêmica e afetiva em me orientar, supervisionar e guiar na clínica e na vida. Pelo seu pensamento livre, pela sua força de dizer, sustentar e argumentar, e pela coragem de ser quem é.

Aos meus colegas do grupo de orientação do doutorado, pela leitura atenciosa e pelas discussões tão enriquecedoras, em especial Lucas Bullara, Marco Aurélio, Felipe MartinsAfonso, Yuri Ferreira.

Aos meus companheiros de trabalho, da (minha) Equipe Novo Olhar, pelas incansáveis discussões, pela disponibilidade e abertura para pensar, repensar, e criar junto. A vontade de encontrar soluções, outras possibilidades, e diferentes formas de manejar as mais específicas situações, é, sem dúvida, o que nos une.

À Lilian Ana Faversani, minha sempre professora, por me convidar e inserir no contexto escolar. Pela interlocução e por seu modo singular de ver, pensar e falar sobre e com as crianças, e sobre as relações.

À Tina, Maria Cristina Oliveira, pela parceria, confiança e disponibilidade para conversar e pensar em estratégias para que os pequenos vivam melhor.

À Simone Pires, pela confiança em meu trabalho e pela parceria nos atendimentos.

Às escolas nas quais acompanhei as crianças, que permitiram que eu fizesse meu trabalho junto aos pequenos, que confiaram e deram suporte para que as transformações todas fossem possíveis. E aos professores com quem muito aprendi no convívio, sobre infância, escola e desenvolvimento. 
Às crianças atendidas por mim e aqui contempladas, que construíram junto comigo os encontros terapêuticos, nos mais diferentes ambientes, mas sempre certos da nossa parceria, por quem tenho um carinho e uma gratidão sem fim.

Aos pais das crianças atendidas por mim e aqui contempladas, pela confiança, dedicação e atenção, pelo carinho dispendidos a mim e ao contexto terapêutico, e, sobretudo, pela parceria. Não fosse a parceria, nada disso seria.

À Karina Pires Pecora, pela confiança, aposta, persistência, parceria, cumplicidade e amizade. Por permitir um cuidado e envolvimento único com seus filhos que já são, também, um pouco meus.

À Regiane e à Fernanda Sazuki, pelas conversas e aprendizagens mútuas a respeito do autismo e da vida.

Aos meus amigos de vida, parceiros de sempre, pela disponibilidade, carinho e afeto sem tempo: Nanci Bührer, Fabiana Marchiori, Gabriela Roecker, Patrícia Morati, Felipe Martins, Lucas George.

Ao meus pais, Roy e Izildinha, por serem parte da minha história e de quem sou.

À minha avó Iolanda, em memória, que tanto me ensinou sobre a vida, as relações humanas e sobre o que nem sei. As lembranças resistem ao tempo. Elas moram em mim.

Ao Daniel Tosto Bogomolow, que talvez mesmo sem saber, foi quem me desafiou e fez com que eu fosse além; buscasse entender, explicar, sentir, construir junto, pensar, organizar e apostar numa clínica para o bem de quem demanda, tomando quem demanda por inteiro. Uma clínica que vive em mim, da qual não me diferencio mais.

Ao Rafael Rodrigues, meu companheiro de vida, de partilhas, por todo seu amor, carinho e apoio. Por sua incansável aposta em mim e parceria contínua.

À Lis, nossa filha, que esteve presente nas últimas linhas desta Tese, e é com quem construo, cotidianamente e em ato, uma relação pautada no respeito, na ética, e no carinho. Estas e todas as outras linhas que estão por vir, não são mais só minhas. 


\section{RESUMO}

Verifica o método da Análise Institucional do Discurso (AID) como uma forma de tratamento para crianças com o diagnóstico de transtorno do espectro autista (TEA). Trata-se de uma pesquisa que apresenta a partir da análise do atendimento dessas crianças pela AID, como é conferido a elas um lugar de enunciação na cena discursiva do tratamento clínico, ainda que, em alguns casos, não falem. São apresentadas análises de 6 atendimentos, em situação de acompanhamento escolar ou atendimento clínico em consultório, com foco no resgate dos diferentes caminhos trilhados pelas crianças como efeito de suas terapias, tendo em vista a ideia básica do brincar como discurso e de seu caráter terapêutico. Também, como essa abordagem contribuiu com a redução dos sintomas associados ao TEA, mensurados pela escala diagnóstica Autistic Diagnostic Observation Schedule (ADOS-2). Tais atendimentos receberam supervisão sob orientação da AID, e foram registrados na ocasião em que ocorreram. Foi observado o protagonismo da criança na cena analítica, em sua história como ponto de partida para sua terapia, bem como os efeitos na terapêutica.

Palavras-chave: autismo; análise institucional do discurso; brincar como terapia. 


\begin{abstract}
It verifies the Institutional Discourse Analysis (IDA) method as a form of treatment for children diagnosed with autism spectrum disorder (ASD). This research presents, based on the analysis of the assistance provided to these children by AID, how they are given a place of enunciation in the discursive scene of clinical treatment, even though, in some cases, they do not speak. Analyzes of 6 appointments are presented, in a situation of school monitoring or clinical assistance in the office, with a focus on recovering the different paths taken by children as an effect of their therapies, bearing in mind the basic idea of playing as discourse and its therapeutic character. Also, how this approach contributed to the reduction of symptoms associated with ASD, measured by the Autistic Diagnostic Observation Schedule (ADOS-2) diagnostic scale. Such assistance received supervision under the guidance of the AID, and were recorded at the time they occurred. The child's protagonism in the analytic scene was observed, in its history as a starting point for its therapy, as well as the effects in the therapy.
\end{abstract}

Keywords: autism spectrum disorder; institutional discourse analysis, play as therapy 


\section{SUMÁRIO}

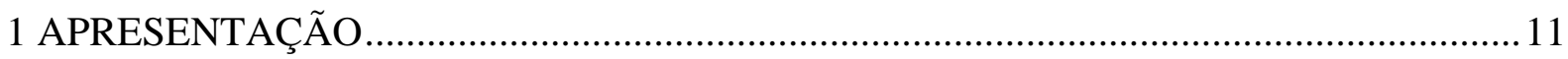

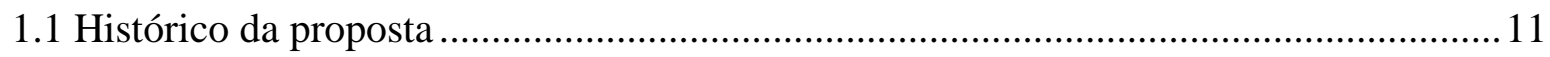

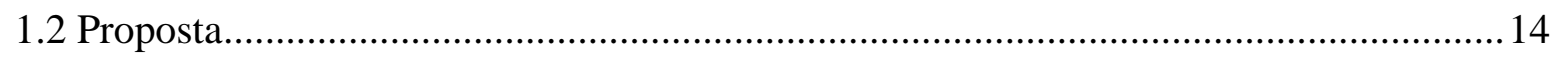

2. NOTAS SOBRE O BRINCAR E O DESENVOLVIMENTO INFANTIL .........................18

2.1 A criança e o desenvolvimento do brincar.................................................................. 19

2.2 Bruner, a interação do bebê com o adulto como precursora da brincadeira ...................20

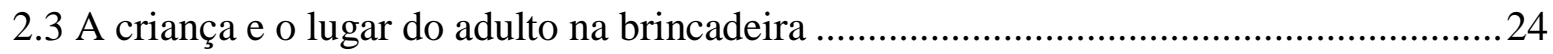

2.4 A criança e a brincadeira imaginativa: decorrências em diferentes dimensões ..............25

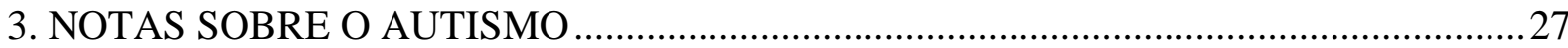

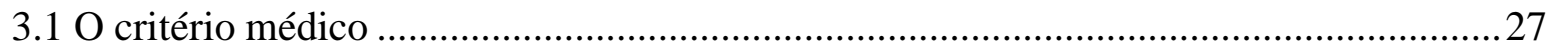

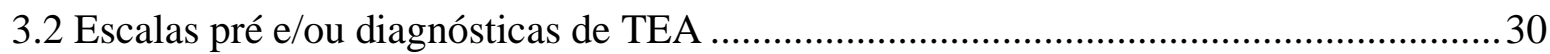

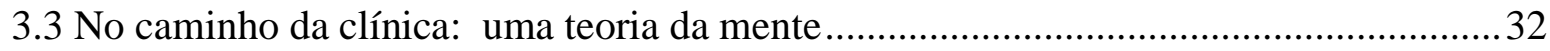

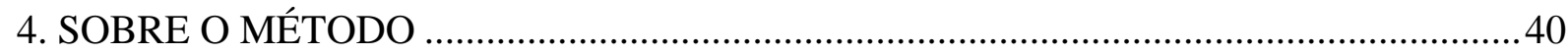

$4.1 \mathrm{O}$ método como estratégia de pensamento.................................................................44

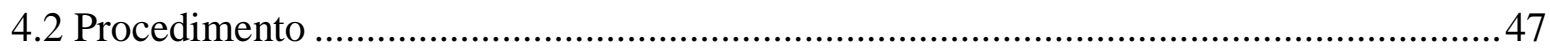

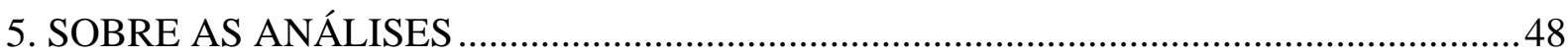

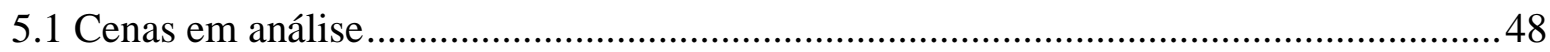

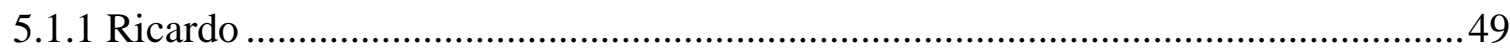

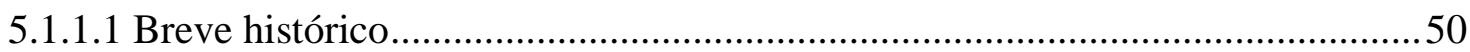

5.1.1.2 Sobre o desenvolvimento de Ricardo durante o atendimento ...........................51

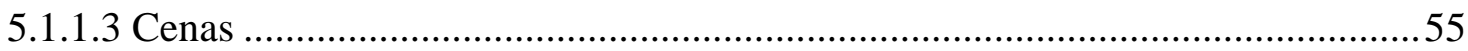

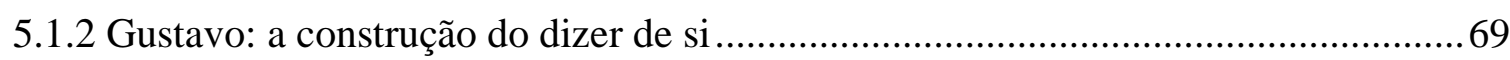

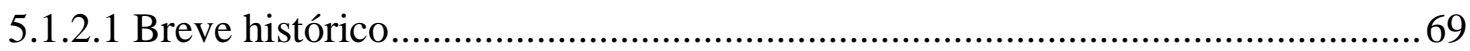

5.1.2.2 Sobre o desenvolvimento de Gustavo durante o atendimento...........................72

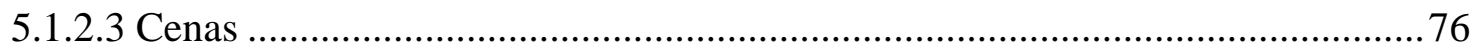

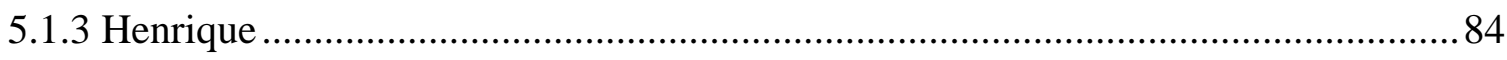

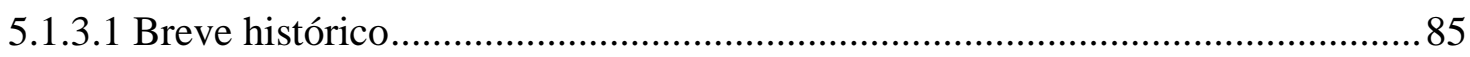

5.1.3.2 Sobre o desenvolvimento de Henrique durante o atendimento ........................86

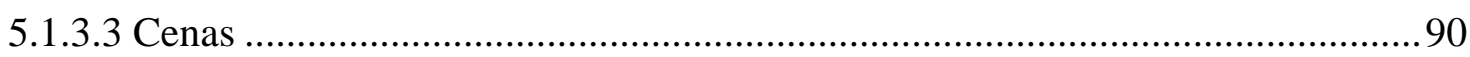

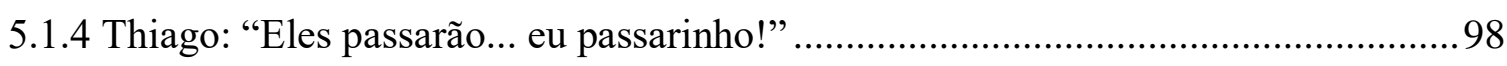

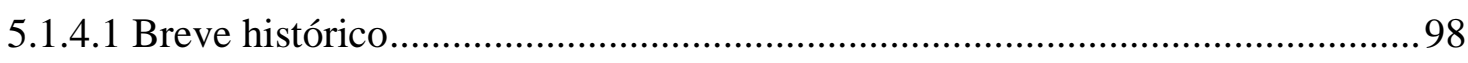

5.1.4.2 Sobre o desenvolvimento de Thiago durante o atendimento ............................ 100

5.1.4.3 Cenas - "Luisa, conta a história do bebê, do Thi e da Luisa!"......................... 104 
5.1.5 Lola: acaso e acontecimento como discurso ....................................................... 120

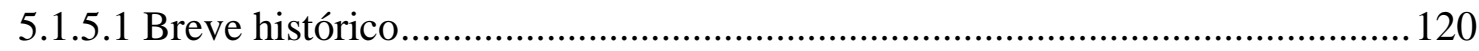

5.1.5.2 Sobre o desenvolvimento de Lola durante o atendimento................................... 123

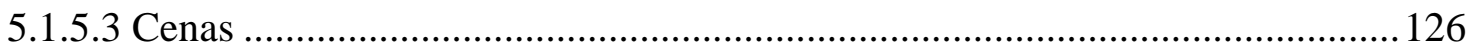

5.1.6 Otávio: atenção e curiosidade no ingresso ao mundo da imaginação e da brincadeira

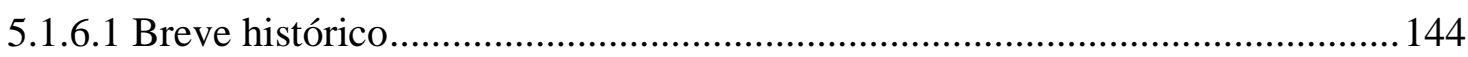

5.1.6.2 Sobre o desenvolvimento de Otávio durante o atendimento .............................146

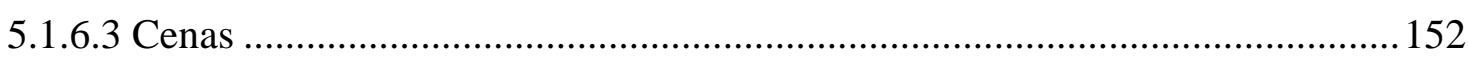

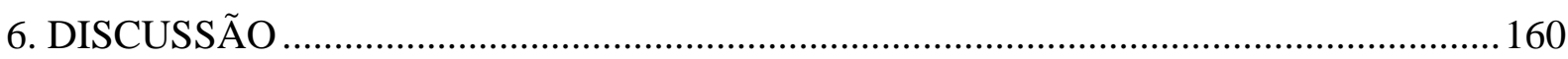

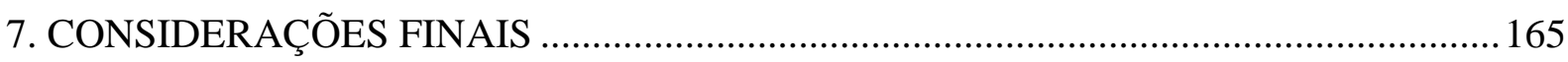

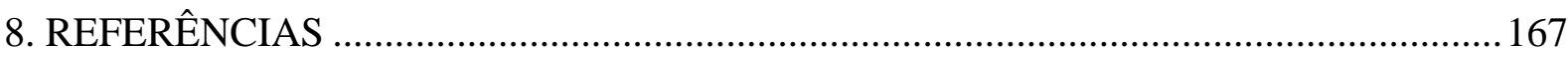




\section{APRESENTAÇÃO}

\subsection{Histórico da proposta}

A presente pesquisa visa a dar prosseguimento às discussões dos resultados de análise feitas em minha dissertação de mestrado. Defendida em 2013, sob orientação de Marlene Guirado, foi publicada em co-autoria com a orientadora em $2014^{1}$, após algumas modificações, sob o título Tratamentos do autismo: a direção do olhar - Uma análise institucional do discurso da psicanálise e da análise do comportamento aplicada, e republicada em $2018^{2}$, após mais algumas modificações, sob o título A direção do olhar nos tratamentos do autismo.

Partimos, então, de uma pesquisa que abordou a psicanálise e a análise do comportamento como formas de tratamento para crianças com o diagnóstico de Transtorno do Espectro do Autismo (TEA), tendo como método de análise a Análise Institucional do Discurso (AID), de Marlene Guirado. Lá, o objetivo foi o de confrontar essas duas abordagens de tratamento para o autismo, tendo em vista que são as mais recorrentes na Psicologia, e que, por teoria e técnica, têm se colocado em polos opostos, não só em relação ao autismo, mas em diversos domínios do saber/fazer.

A análise foi feita a partir de entrevistas abertas com os profissionais dessas duas abordagens, possibilitando que o entrevistado contasse "sobre seu trabalho, suas dificuldades e suas facilidades, sobre casos exemplares de atendimento frustrado ou bem-sucedido, sobre seu cotidiano profissional e sua clientela" (Guirado; Guirado, 2018, p.20). Esse modo de entrevista, já na perspectiva da AID, aliado aos procedimentos de análise do mesmo método, nos permitiu configurar o lugar da criança e dos outros personagens nas cenas de cuidado e tratamento desta, e o lugar da teoria ou dos pressupostos sobre o autismo como doença, incluindo as expectativas de progresso com o tratamento.

Os resultados apontaram em duas direções: de um lado, as diferenças, esperadas, até certo ponto, por conta do embate histórico; e, de outro lado, as semelhanças, surpreendentes, principalmente no que diz respeito ao lugar da criança com autismo. Iremos explicitá-las aqui, para que possamos prosseguir e alcançar o objetivo desta tese.

\footnotetext{
${ }^{1}$ GUIRADO, L.; GUIRADO, M. Tratamentos do autismo: a direção do olhar - Uma análise institucional do discurso da psicanálise e da análise do comportamento aplicada. Saarbrücken: Verlag/Novas Edições Acadêmicas, 2014.

${ }^{2}$ GUIRADO, L. GUIRADO, M. A direção do olhar nos tratamentos do autismo. Curitiba: Appris Editora, 2018.
} 
As diferenças aparecem logo no começo do trabalho, nas entrevistas das psicólogas à pesquisadora:

(...) as psicanalistas mostraram ter em mim uma interlocutora; faziam-me perguntas, queriam saber se estavam respondendo ao que fora perguntado, se estavam sendo claras. Das entrevistadas da análise do comportamento, apenas uma, Elis, teve a mesma atenção e mostrou diretamente que notava minha presença. (...) Uma hipótese, apoiada nessa variação apresentada pela análise do discurso de Elis, é de que o discurso do método é imperioso na determinação da atenção do terapeuta, inclusive quando ele está na condição de entrevistado. (Guirado; Guirado, 2018, p.98)

E seguem, discurso afora: as psicanalistas fundamentam a psicanálise e os procedimentos desta em autores de referência e casos desses autores e delas mesmas. As analistas do comportamento, não. Têm a análise do comportamento determinada e seus procedimentos garantidos conforme uma "recomendação internacional", conferindo, assim, ao método um lugar de extrema potência, e a elas um lugar de porta-voz deste.

As psicanalistas

(...) observam o autismo da teoria aprendida e apreendida - o qual assume formas visíveis que se desenham - menos no comportamento e mais no pressuposto. O que não acontece com as analistas do comportamento, que falam mais de criança e comportamento do que de autismo, prevalecendo a potência da ação planejada, do procedimento metodológico, que age sobre os comportamentos, de maneira geral. (Guirado; Guirado, 2018, p.100)

Dessa forma, em uma abordagem a criança fica encoberta pelo autismo e seus pressupostos, na outra, o autismo e a criança (que aparece sempre como genérica frente aos procedimentos) ficam encobertos pelos procedimentos e registro. Partindo dessa diferença entre a psicanálise e a análise do comportamento, chegamos, em 2013, a uma conclusão importante e relevante para a elaboração desta tese: na psicanálise o autismo é a instituição da criança, e na análise do comportamento, a instituição é o próprio registro/procedimento.

Como foi possível chegar a esta conclusão e o que ela implica?

Explicamos: a AID parte do conceito de instituição, de J.A. Guilhon Albuquerque, em uma perspectiva sociológica específica, de instituição como práticas sociais que se repetem e que, nessa repetição, se naturalizam; são reconhecidas como legítimas, desconhecendo-se sua condição de instituídas. A relação entre agentes e clientela é que define o objeto institucional, ou seja, aquilo em nome de que a instituição se faz (Guilhon-Albuquerque, 1978). Isto posto, dizer que, na psicanálise, o autismo é a instituição da criança, significa dizer que a direção do olhar é para o autismo da teoria, e é a partir dele que se poderá olhar para a criança e reconhecer 
nela os traços e as características do autismo. E na análise do comportamento, a direção do olhar é para o registro e o procedimento e como eles provocarão as mudanças esperadas pelos terapeutas na criança com autismo.

Atente o leitor para um acontecimento discursivo para o qual aponta nossa análise, organizada que está por um campo conceitual que supõe um determinado conceito de instituição. A ele retornaremos mais tarde destacando os efeitos de desconhecimento que, contra-face dos reconhecimentos, acabam por definir/mostrar um inesperado ponto de semelhança entre os discursos de tratamento que se põem tão díspares...

Continuemos por enquanto com as diferenças: na análise do comportamento, a individualidade da criança aparece no que é reforçador para ela, e é a analista que produz o limite desta individualidade, ao poder olhar para o evento chamado reforço. Já na psicanálise, a individualidade da criança e seus limites, supostamente, surgiriam na relação com a analista.

Em relação à observação da criança, ambas as abordagens a fazem, mas em diferentes modalidades: as analistas do comportamento buscam verificar a mobilidade do reforçador para a modificação do comportamento, e

\begin{abstract}
as psicanalistas observam para se posicionar diante da criança, fazer interpretações, constituir vínculo, fazer contato (assim o dizem, sem se dizer da determinação que os pressupostos teóricos exercem na definição de cada um desses termos: interpretação, vínculo, contato). (Guirado; Guirado, 2018, p.100,101)
\end{abstract}

Os limites que as profissionais apontam na forma de tratamento com que trabalham também diferem.

\begin{abstract}
Os limites da psicanálise aparecem sempre instrumentados pelas exigências dos pais em relação à frequência e à duração do tratamento, o que faz com que essa abordagem fique, de acordo com as psicanalistas, em constante risco de ataque em relação ao método da análise do comportamento aplicada. Em compensação, as analistas do comportamento não apresentam limites para o método, dando a entender que fora do método não há potência possível. O que dificulta o método, segundo elas, é algo que está fora dele, como a criança com idade avançada para o início do tratamento; o erro devido a algum mau planejamento de procedimentos e/ou registros, por exemplo. (Guirado; Guirado, 2018, p.101)
\end{abstract}

Sobre os pais, as duas abordagens os consideram como parte no atendimento da criança, e colocam para si a tarefa de educá-los. Entretanto, a psicanálise lida com a oposição dos pais com um genérico "manejo da transferência", e a análise do comportamento lida, dispondo-se

\footnotetext{
${ }^{3}$ Genérico no sentido de não ter maiores explicações sobre o que seria isso ou como se faria isso.
} 
a ensiná-los com os mesmos recursos com que ensinam as crianças (generalizando o trabalho do terapeuta).

Vamos, agora, às semelhanças. São em menor quantidade do que as diferenças, mas tão ou mais importantes.

As entrevistadas das duas abordagens relataram dificuldade em trabalhar com "crianças mais velhas", sem especificar a idade. Também se referiram a uma mudança em seus comportamentos quando a criança apresenta algum tipo de oposição ou resistência.

A semelhança mostrada pela análise das entrevistas e que se tornou a chave para a extensão do mestrado em um doutorado, no entanto, é a que sinalizamos alguns parágrafos acima e que segue, agora, na íntegra, tal como se apresenta no livro:

\begin{abstract}
A analista do comportamento (Elis) que fala sobre um acompanhamento terapêutico descreve um olho que observa e registra, e a psicanalista (Lídia) descreve-se como um radar para o que a criança sente e diz, que lhe agrada compreender o contato e o vínculo estabelecido com ela. Aparentemente fazem coisas distintas, entretanto, é na situação descrita pela analista do comportamento que algumas águas se turvam e algumas semelhanças parecem se destacar: ela se cansa de repetir instruções, se cansa de ter de evocar seu paciente para cumprir as exigências, e ela se surpreende quando, com muita facilidade, a criança atende ao chamado de um colega. Provavelmente, para que isso tudo ocorra, Elis tenha tido de deslocar o olhar do procedimento para a criança e para a relação desta com o contexto. Isso pode nos levar a pensar que as diferenças entre o lugar atribuído à criança na análise do comportamento e na psicanálise não sejam assim tão radicais quanto aparentam ser. Tanto em uma quanto na outra, é sempre em uma linha direta, imediata, que se admite uma transparência naturalizada do sentir (radar para sentir) até o avaliar (registrar e avaliar). Um reconhecimento que faz desconhecer, no mesmo ato, a teoria ou o método como ocasião dessa "transparência". De qualquer forma, tanto em uma forma de tratamento quanto em outra, a criança pode passar sem discurso. Ou melhor, seja na psicanálise ou na análise do comportamento aplicada, a criança com autismo, tudo indica, não ocupa um lugar de enunciação. (Guirado; Guirado, 2018, p.102,103)
\end{abstract}

\title{
Retomemos.
}

\subsection{Proposta}

Tal semelhança é chave para a produção de uma tese de doutorado, uma vez que foi a partir dela que conseguimos configurar: a) essa curiosa produção de relação entre o terapeuta e a criança, que se orienta menos pelo que a criança enuncia como desafios e resistências, e mais pelo que o terapeuta já sabe fazer ou já pressupõe sobre o seu sentir e seus sentidos; b) nas tensões entre a psicanálise e a análise do comportamento pela apropriação do autismo como objeto institucional, o autismo se torna público (pais, psicólogos, médicos, professores e outros profissionais passam a referendar e dar visibilidade à abordagem que fala sua língua, que chega 
mais perto de sua demanda, com alvos mais tangíveis para o tratamento, que lhes atribui algum lugar como interlocutor), mas a criança continua ocultada pela não conferência de seu lugar na cena enunciativa. Isto é, a criança não tem sua ação reconhecida como produtora de discurso em seu próprio atendimento; os lugares de enunciação, que são os lugares que legitimam o saber/fazer/agir/mudar, são reservados, como visto anteriormente, às teorias, aos métodos e procedimentos sobre o autismo.

Nossa proposta para a presente tese é demonstrar que o psicólogo pode fazer a terapêutica do autismo numa direção diferente: tomando a relação da criança com ele e com o brincar como discurso em análise.

Para que essa demonstração seja possível, algumas considerações se fazem necessárias. Como todas elas decorrem da estratégia conceitual da análise institucional do discurso, dedicamo-nos, nesta Apresentação a declará-las, ou melhor, enumerá-las, desde a questão que orientará a pesquisa até os procedimentos de análise, passando pela escolha do material discursivo que será trabalhado e que organiza o pensamento e o quadro final dos resultados a que se puder chegar. Vamos chamar de Regras de Prudência ${ }^{4}$ para a análise e/ou pontos conceituais estratégicos:

(a) Tomaremos discurso, por conceito e método, não necessariamente como fala, mas como ato, conforme sustentamos pela estratégia de pensamento da AID, na dissertação, e manteremos como condição imprescindível para conduzir a presente pesquisa.

(b) É assim que poderemos produzir um desdobramento importante: o brincar pode ser tomado como discurso. E, assim, ele será o organizador concreto da cena de tratamento (Guirado M. , Uma analista do discurso no espectro de tratamentos do autismo, 2018). Nesta cena, a criança, como parceira do jogo/brincar terá lugar garantido de voz, de enunciação, mesmo que sua comunicação não seja precipuamente verbal. Também terá lugar o terapeuta, e a sessão será a ocasião dessa especial interlocução.

(c) Muitas vezes, quando uma criança com o diagnóstico de autismo chega ao consultório, costuma-se dizer que ela não consegue ainda brincar. Nem sozinha, nem acompanhada. Para nós, no entanto, logo no início de um processo terapêutico, a cena discursiva ${ }^{5}$ do brincar está colocada, com as tensões e acomodações de e nos lugares da

\footnotetext{
${ }^{4}$ Foucault, A ordem do discurso, 1971/1996

${ }^{5}$ Cena discursiva é o termo que na análise pragmática do discurso dá conta de tratar do modo como se articulam cenografia e cena genérica, ou seja, o contexto concreto da relação (cenografia) e a definição genérica de papéis ("cena genérica").

Cenografia como "o nível da relação, do tipo de relação que cada discurso estabelece, a relação na qual estamos implicados”. (Guirado, 2010, p.109)
} 
criança e do terapeuta. E essa é a hipótese fundamental da presente pesquisa, que terá o brincar como modalidade de atendimento (Guirado M. , Uma analista do discurso no espectro de tratamentos do autismo, 2018).

(d) Sabemos que a literatura sobre o brincar e o brinquedo se estende em várias direções e supõe vários outros conceitos. Esperamos, no entanto, ter fundamentado com suficiência que, ao tratar o contexto de uma sessão terapêutica como ocasião de uma relação em que lugares institucionais de adulto-terapeuta e criança-paciente são marcados, apontem para a especificidade do brincar entendido agora como discurso, e o discurso como ato. Mesmo assim, abrimos espaço, logo no capítulo seguinte (2), para trazer alguns trabalhos sobre o brincar, inserindo-os na perspectiva dessa tese.

(e) Como se pode notar, até agora, referimo-nos ao brincar-ato-terapêutico no atendimento a crianças com autismo. Esta tese também apresentará um capítulo (3) que resumirá estudos e trabalhos sobre o diagnóstico de autismo. Isto será feito na perspectiva de situar o campo atual das concepções, pesquisas e expectativas em torno dessa que é a proposta básica de nosso doutorado: operar uma modalidade de tratamento que parte da consideração dos discursos em jogo no cenário geral e naquele específico do atendimento dessa clientela, dando destaque, sobretudo, ao lugar de enunciação da criança.

(f) Finalmente, por decorrência das discussões que se puderem delinear a partir dessas considerações, pode-se também apontar para um âmbito de ação possível aos tratamentos. A bem da verdade isto não é sequer privilégio dos discursos de profissionais, uma vez que, no caso do autismo, sobretudo pais e famílias têm se preocupado muito com a questão das modalidades de atendimento. Expliquemos melhor. Comumente, quando se pergunta a um psicólogo como ele trabalha, tem-se como expectativa de resposta: psicanálise ou análise do comportamento. Como se essas fossem as únicas opções. Então, alguém como esta pesquisadora que não trabalha com nenhuma das alternativas anteriores, encontra dificuldade de se fazer situar. E se reforça o objetivo do presente estudo: demonstrar que o psicólogo pode fazer a terapêutica do autismo tomando a relação da criança com ele e com o brincar como discurso em análise. E a análise de discurso, ainda que possa soar estranho ao senso comum, poderá ser uma modalidade de tratamento de crianças nessas condições.

(g) Apresentaremos, então, como quinto capítulo da tese, alguns atendimentos realizados (por mim) com e na perspectiva da análise institucional do discurso a crianças com

Cena genérica como "o nível de análise que se atém ao quadro geral que define os papéis ativados numa relação”. (Guirado, 2010, p.109) 
diagnóstico de autismo (conforme laudo médico via DSM-56 (2014) ou CID-10 ${ }^{7}$ (1997), e confirmação diagnóstica pela escala ADOS (2012) - Autistic Diagnostic Observation Schedule) por mim aplicada. A ideia é de resgatar os diferentes caminhos trilhados por elas como efeito de suas terapias, tendo em vista que partimos dos princípios metodológico-conceituais aqui apresentados. Alguns desses atendimentos ocorreram em situação de acompanhamento escolar e outros de atendimento clínico em consultório, sendo que ambos receberam supervisão na orientação da AID e foram registrados (registros pessoais escritos de todos os casos, e algumas fotos e vídeos) na ocasião em que ocorreram.

Será, assim, por meio dessas situações de análise de discurso em ato, que explicitaremos essa forma de tratamento que tem por meio e fim colocar as crianças atendidas como interlocutores com lugar de enunciação na cena discursiva do tratamento clínico, ainda que, como dissemos, em alguns casos, elas não falem.

\footnotetext{
${ }^{6}$ Diagnostic and Statistical Manual of Mental Disorder - 5a edição revisada, 2014.

${ }^{7}$ Classificação Estatística Internacional de Doenças e Problemas Relacionados à Saúde, 10ª revisão, 1997.
} 


\section{NOTAS SOBRE O BRINCAR E O DESENVOLVIMENTO INFANTIL}

Neste capítulo iremos apresentar algumas notas sobre o brincar e o desenvolvimento infantil a partir de autores da área da educação e da psicologia que trabalham com descrição de cenas.

É preciso fazer uma ressalva neste ponto da tese: a AID, como estratégia de pensamento, como método, não parte de uma teoria prévia para com e através dela observar determinado objeto de estudo. Por conta disso, esse capítulo tem como objetivo apenas mostrar ao leitor, de forma breve, como algumas teorias sobre o brincar instrumentalizam a nossa posição, o nosso lugar. Isso significa dizer que essas teorias ficam em um plano de fundo, como descrições de aspectos do desenvolvimento; nós sabemos que elas existem, mas o norte da análise, o horizonte que está no recorte, é a ética analítica da AID: garantir que a criança possa brincar porque é no brincar que ela vai tomar um assento, e o analista também, para terem enunciação.

Seguimos.

Costuma-se dizer que o brincar é uma forma de expressão e comunicação. Conforme Sutton-Smith (1986), "é a linguagem primeira, aquela em que o componente expressivo é mais importante do que o componente instrumental. É também uma linguagem porque leva a pessoa que brinca a uma comunidade mútua de expressão" (Sutton-Smith, 1986, p.12).

Isso se processaria, desde que a criança ainda é um bebê, com a exploração sensóriomotora de seu próprio corpo e dos objetos do mundo ao seu redor. Essa curiosidade e exploração do ambiente, aliado ao sorriso do bebê na percepção do rosto de outras pessoas, promoveria as primeiras interações entre o bebê e o cuidador. E, embora neste primeiro momento o cuidador desenvolva um papel mais ativo de falar, acariciar, tocar e sorrir de volta ao sorriso do bebê, como dizem Singer e Singer (2007), são essas interações que possibilitam, inclusive, que conduza à dimensão imaginativa na brincadeira.

A criança começaria a reconhecer as características de um jogo e a se colocar de forma mais ativa na interação:

A seguir, ela vai poder tornar-se um parceiro, assumindo o papel da mãe, ainda que de forma desajeitada, p. ex. nas brincadeiras de esconder uma parte do corpo. A criança aprende assim a reconhecer certas características essenciais do jogo: o aspecto fictício, pois o corpo não aparece de verdade, trata-se de um faz-de-conta; a inversão dos papéis; a repetição que mostra que a brincadeira não modifica a realidade, já que se pode sempre voltar ao início; a necessidade de um acordo entre parceiros, mesmo que a criança não consiga aceitar uma recusa do parceiro em continuar brincando. (Brougère, 2015, p.22) 


\subsection{A criança e o desenvolvimento do brincar}

Consideramos o brincar como o fazer primordial da criança, e ele se desenvolve e se diferencia com o desenvolvimento global dela, de suas percepções do mundo ao redor, do aprimoramento de suas competências cognitivas.

Conforme Singer e Singer (2007), entre 1 e 3 anos de idade, a criança é capaz de envolver-se em jogos lúdicos simples envolvendo ela própria e/ou objetos, que são repetições/imitações de ações que ela mesma faz ou vê outros fazendo. Alguns exemplos: dar comidinha com uma colher para o bicho de pelúcia; escovar o dente da boneca com uma escova de dente; trocar a fralda da boneca; entre outros. Além disso, após uma brincadeira com pares e/ou adultos, ela, sozinha, também pode copiar algumas das atividades da brincadeira feita em conjunto.

Para estes autores, por volta dos 3 anos é quando a criança tem mais competências para fazer um jogo lúdico cooperativo. Isto é, em uma brincadeira imaginativa "as crianças podem assumir diferentes papéis, inverter papéis e seguir um script ou roteiro simples. (...) estabelecem regras quando desenvolvem seus scripts para uma determinada brincadeira. Elas aderem rapidamente a essas regras e a criança que não segue o script é eliminada do jogo" (Singer; Singer, 2007, p.43).

Durante a pré-escola e os anos iniciais do ensino fundamental, teríamos a evolução do jogo lúdico cooperativo para o lúdico social, em que haveria "muitas transformações de materiais, linguagem mais avançada, scripts mais elaborados e inúmeras regras societárias" (Singer; Singer, 2007, p.44). E, segundo os mesmos autores, a partir dos 6 anos, uma outra forma de brincar também se apresenta como primordial: o jogo de regras de tabuleiro e/ou cartas.

Outro autor que também constrói uma compreensão do desenvolvimento do brincar, é Daniil B. Elkonin. Ele apresenta quatro níveis de desenvolvimento do jogo na idade pré-escolar, mas, diferentemente de Singer e Singer (2007), não associa esses níveis a idade, e sim a fases de desenvolvimento, sendo que crianças de uma mesma faixa etária poderiam se encontrar em diferentes níveis e entre dois níveis ao mesmo tempo.

De qualquer maneira, o primeiro nível de desenvolvimento do jogo, nesse sentido, vai ao encontro da ideia dos Singer sobre a brincadeira a partir do terceiro ano de vida: 
representação desses papéis é dar de comer a alguém. (...) Os papéis são determinados pelo caráter das ações, e não são eles que a determinam. (...) As ações são monótonas e constam de uma série de operações que se repetem. (Elkonin, 2009, p.295-295)

No segundo nível, o conteúdo fundamental do jogo seria a ação com o objeto. Nele os papéis são denominados pelas crianças, assim como as funções entre elas; a lógica das ações ocorreria conforme elas acontecem na vida real; o tema de dar comida sofre expansão e passa a contemplar a ação de cozinhar, servir à mesa, e comer; e as crianças começam a estranhar a alternação na continuidade das ações.

No terceiro, o conteúdo fundamental seria a interpretação e apropriação das crianças por seus papéis. Neste momento, “As crianças mencionam os seus papéis antes de o jogo começar. Os papéis determinam e encaminham o comportamento da criança” (ELKONIN, 2009, p.297). As ações são mais variadas, e vão além de um tema central, como dar comida; e as crianças percebem melhor o contexto, enredo da história que estão criando, e protestam quando a lógica das ações é infringida.

Por fim, no quarto nível: "O conteúdo fundamental do jogo é a execução de ações relacionadas com a atitude adotada em face de outras pessoas cujos papéis são interpretados por outras crianças" (Elkonin, 2009, p.298). Nele, as crianças apropriam-se de seu papel de forma até a modificar sua fala para adequar-se ao seu papel. Além da lógica pautada pela realidade, têm-se também um destaque para a racionalidade das regras.

Estes seriam os desdobramentos de um brincar que teve seu início nas primeiras interações do bebê com o adulto, como um componente expressivo.

E, com isso, pelos discursos outros, o das teorias sobre desenvolvimento da criança, podemos ampliar nossa compreensão sobre o pequeno interlocutor e suas competências na cena do brincar. Prossigamos, porque este parece ser um caminho intrigante onde um autor, Bruner, contribui de forma bastante especial.

\subsection{Bruner, a interação do bebê com o adulto como precursora da brincadeira}

Jerome Bruner (1983), em seu livro Child's talk - Learning to use language, faz uma descrição e análise da evolução de uma brincadeira - peekaboo - entre uma mãe e seu bebê, com inicialmente 5 meses, que nos mostra o quão fundamental é o jogo na constituição do lugar de enunciação de uma pessoa, ainda que muito pequena.

Bruner (1983) não usa o termo "lugar de enunciação", que aqui estamos nos propondo a trabalhar. Entretanto, é possível depreender de suas palavras, que essas interações na primeira 
infância já fazem, "naturalmente", com que o bebê ocupe um lugar de potência e enunciação. Isto é, seja reconhecido como alguém que pode responder, que entende, que pode se comunicar mesmo que não fale, que pode explorar o ambiente e a relação com a pessoa que brinca com ele, que pode entrar e compartilhar de regras simples. ${ }^{8}$

Para que fique mais claro para o leitor, iremos colocar aqui trechos do caso descrito por este autor, e daremos destaque ao que nos permitiu fazer tal aproximação desta interação inicial como precursora do lugar de enunciação.

A criança chama-se Jonathan, e desde os 3 meses a mãe brincava com ele de esconder seu próprio rosto, ou o dele, e aparecer, e ele demonstrava interesse pela brincadeira. $\mathrm{O}$ autor propôs um estudo longitudinal a esta família (que consiste de mais um irmão), e fez observações regulares de Jonathan dos 5 aos 14 meses envolvendo uma brincadeira de base com o desaparecimento e reaparecimento de um objeto: peekaboo (cadê-achou), com um palhaço que aparecia e se escondia em um cone.

Bruner coloca que aos 5 meses Jonathan era um sorridente espectador, e que logo começou a antecipar o que aconteceria em seguida e a entrar na brincadeira. A mãe dele alterava seu papel conforme o desenvolvimento da brincadeira e interação com ele:

Para onde ele foi? Ela usa essa pergunta padrão quarenta e três vezes entre o quinto e nono mês de Jonathan. Em 0;7 ela adiciona a essa frase padrão, Cadê ele?; em 0;8, Ele está aqui?; Dá pra ver ele?; e, em 0;9, Cadê o palhaço? (introduzindo o nome) - são todas formas suplementares. Era evidente que à medida que esses novos elementos se tornavam "previsíveis", Jonathan poderia esperar que sua mãe os utilizasse, olhando-a por meio do palhaço e do cone e sorrindo em antecipação ou depois de sua fala. A rica linguagem da mãe foi se tornando parte do jogo. Cada vez mais, ele, também, poderia vocalizar durante esses momentos entre as frases dela. A omissão de frases da mãe de Jonathan nos momentos em que estas eram esperadas por ele aconteceu de forma muito interessante. (...) expressões que por sua natureza seriam muito mais próximas à ação da criança e suas intenções presumidas e muito menos ritualizadas. As supressões foram estimuladas de maneira que coincidiam com o domínio/aprendizado de Jonathan no jogo. Quando uma fala, de fato podia ser pressuposta, a vocalização da mãe não aparecia. Isso era uma maneira marcante de estabelecer a convenção da pressuposição. (Bruner, 1983, p.52, nossa tradução ${ }^{9}$ )

\footnotetext{
${ }^{8}$ Essa perspectiva de potencialização da criança, suas razões e seus afetos na história de desevolvimento, encontrase, ainda, na produção científica voltada sobretudo para a pesquisa neurológica e etiológica, bem como a relação entre o que é inato e que se desenvolve a partir do nascimento. Os atributos que descrevemos, nesse âmbito de estudo, estariam presentes desde o nascimento como disposições inatas, como garantia de sobrevivência. O brincar se inclui entre esses atributos universais da infância (Nagy; Molnar, 2004, p.54-63).

${ }^{9}$ Where's he gone? (...) She used this standard question forty-three times beetwen Jonathan's fifth and ninth month. At 0;7, she added to this standard frase Where is he?; at 0;8, Is he in there? Can you see him?; and at 0;9, Where is the clown? (introducing the nominal) - all suplemental forms. It was evident that as these new features became "expectable", Jonathan would wait for his mother to utter them - looking up at her from the clown-and-cone and smiling either in anticipation or after she spoke. Her richer language was becoming a part of the game. Increasingly, he, too, would vocalize during these junctures between the constituents.
} 
Este trecho nos mostra um pouco sobre o modo como a mãe de Jonathan se relacionava com ele: ela fazia perguntas; supunha que ele entendia alguma coisa do que ela estava dizendo; modificava suas perguntas com o tempo em decorrência de sua observação de que determinada pergunta já estava sendo pressuposta por ele.

Em que pese o caráter experimental e repetitivo dos exercícios (quase um treino), podese detacar aí uma cena básica em que há uma atenção e observação desta mãe em relação ao seu filho, que favorece que ele cresça reconhecendo-lhe um lugar e ocupando ela própria outro lugar na relação com ele. Seu olhar atento às respostas dele e também atento às suas propostas possibilita isso; ela o trata como alguém que é capaz de compreender, responder, pressupor, e, principalmente, de mostrar tudo isso para ela em ato.

Bruner nos descreve, também, as ações e reações de Jonathan nesta brincadeira, conforme os meses. Podemos acompanhar, desta forma, como Jonathan foi conseguindo ampliar sua participação, e até mesmo passar de espectador para agente-condutor. Isto é, a atenção compartilhada exercida por uma pessoa atenta aos movimentos e interesses da criança foi suficiente para que se estabelecesse uma troca de turnos de ação e de expectativa sobre a resposta do outro. Tanto ela quanto ele modificavam suas ações conforme o que percebiam do/no outro.

Nas palavras do autor:

Em 0;5 a tentativa de agarrar o palhaço ganha a cena. Em 0;6 ele acompanha suas tentativas de alcançar ou agarrar o palhaço de vocalizações indiferenciadas. (...) Em $0 ; 7$, começa a responder ao ritmo previsível do jogo. Ele perde interesse em agarrar e agora reage a pontos apropriados, sorrindo e dando risadas. (...) seu sorriso e vocalizações eram "compartilhados" com a mãe quando estabeleciam contato visual enquanto ela falava, colocando o palhaço novamente em cena.

Em seguida, Jonathan toma um papel mais ativo, tentando desajeitadamente criar ele mesmo o aparecimento e reaparecimento. Não mais satisfeito em ficar meramente surpreso com o palhaço, em 0;8 ele está pronto para tirar o palhaço do cone sozinho. Quando sua mãe limita seus esforços ele perde atenção. Em 0;9 lhe é permitido tocar e segurar o palhaço durante alguns momentos em quase todas rodadas. Então, ele vocaliza com sua mãe pelo menos por um momento de todo jogo. (Bruner, 1982, p.5253, tradução nossa ${ }^{10}$.)

The omission of expected utterances was handled in an interesting way by Jonathan's mother. (...) utterances that by their nature were much more closely tied to the child's action and presumed intentions and far less ritualized in character. The deletions were paced in such a way that they coincided with Jonathan's mastery of the game. When a constituent, in effect, could be presupposed, the mother's vocalization was deleted. It was a striking way of estabilishing a convention of presupposition. (Bruner, 1983, p.52)

${ }^{10}$ At $0 ; 5$, attempting to grab the clown dominated the scene. By $0 ; 6$, he accompanied his attempts to reach or gradb the clown with undifferentiated vocalizations. (...) by $0 ; 7$, Jonathan began responding to the game's predictable rhythm. He lost interest in grabbing and now reated at appropriate points by smiling and laughter. (...) his smiling and vocalizations were "shared" with the mother as they established eye contact while she talked the clown back into REAPPEARANCE. 
Bruner continua sua descrição do caso. Jonathan, ao final dos 9 meses, perde um pouco o interesse pela brincadeira e passa a explorar o palhaço e o cone manualmente. Conforme seu desenvolvimento sensório-motor transcorria, ele passou a preferir objetos que dessem a ele maior possibilidade de exploração no espaço.

A estrutura da brincadeira do cadê-achou permaneceu, mas ganhou novos desdobramentos, contemplando a atual fase do menino: a mãe passou a esconder um animal de brinquedo atrás de si e a surpreender Jonathan fazendo o brinquedo reaparecer e dizendo “Boo!"’. Nesta ocasião, pela primeira vez, Jonathan fez uma tentativa de fazer um som em consonância ao de sua mãe.

Com 10 meses esta nova versão ganhou uma outra: a mãe de Jonathan passou a esconder-se atrás de uma cadeira enquanto ele aguardava que ela reaparecesse. Aos 12 meses ele passou a se esconder atrás da mesma cadeira e, aí, ele não determinava apenas quando iria esconder, mas também quando iria reaparecer. E, por fim, aos 14 meses, a brincadeira com o palhaço e cone voltou, mas agora com certa negociação para ver quem iria ser o agente do jogo! Sem dúvida, Jonathan preferia exercer o papel mais ativo, mas não chegava a monopolizá-lo, segundo o autor.

Bruner nos diz, então, que a partir deste ponto da brincadeira, mãe e filho passaram a exclamar "Boo" quando o palhaço aparecia, em uníssono, não importando quem estava fazendo o palhaço aparecer. E vai além: faz uso de todo o desenrolar e desenvolvimento desta interação e brincadeira para nos mostrar que Jonathan, não só desenvolveu a linguagem performática, como também aprendeu a manejar a interação (Bruner, 1982, p.55).

Pensando sobre essa análise de Bruner, talvez possamos dizer, que foi esta brincadeira entre o menino e sua mãe o suporte concreto para que marcassem lugares enunciativos na relação que também estavam, ali, constituindo juntos. Jonathan claramente dava direções, ainda que não falasse, e a mãe observava e seguia, ainda que falasse.

No entanto, essa modalidade de relação (e acrescentamos, mediada pelos afetos) destacada, para fins de demonstração de suas hipóteses e teses sobre a importância do encadeamento de comportamentos específicos para o estabelecimento de respostas também específicas, deixa em aberto que, em outras situações, a mesma estrutura observada no brincar

Soon after, Jonathan began taking a more agentlike role, trying clumsily to produce the disappearance and reappearance himself. No longer pleased to be merely surprised by the clown, by $0 ; 8$ he was ready to get the clown up out of the cone by himself. When his mother limited his efforts, his attention lagged. (...) by $0 ; 9$, he was permited to touch and hold the clown during some constituents of nearly every round. By then, he was vocalizing along with his mother on at least one constituent of every game. (Bruner, 1982, p.52-53) 
também deva ter ocorrido. A exemplo: alimentação, troca de fraldas, cuidados de higiene, adormecimento.

\subsection{A criança e o lugar do adulto na brincadeira}

Pelo que acima consideramos sobre o desenvolvimento infantil, os adultos têm um lugar importante. Não só pelo cuidado, pela satisfação das necessidades básicas, e responsividade aos sinais desde o bebê, mas também e, principalmente, pela qualidade do contexto da relação, que seria a condição desse desenvolvimento.

No que diz respeito à brincadeira com a criança pequena, conforme Bodrova e Leong (2006, p.170), é fundamental que o adulto busque situações imaginárias potenciais, os papéis e as regras implícitas, os usos da linguagem para descrever as ações, e encontre formas de facilitar a interação social entre pares ou a inclusão de uma criança no grupo (caso se aplique à situação, isto é, se for mais de uma criança e um adulto).

Seguem esses autores afirmando que com a criança pré-escolar, cabe ao adulto fazer sugestões e/ou ajudar a organizar a brincadeira de forma a expandir e encorajar sua imaginação. E, por fim, com a criança do ensino fundamental, o papel do adulto fica reduzido a esclarecer as regras dos jogos; elas têm mais habilidades já desenvolvidas e precisam menos de intervenção e/ou mediação (Bodrova; Leong, 2006, p.171,172).

Trazendo para a perspectiva e referência metodológica com que trabalhamos nesta tese (o brincar como ato-dispositivo com assentos de adulto e criança no contexto terapêutico), a atenção do terapeuta é importante fator para que a brincadeira aconteça.

No meu trabalho como terapeuta de crianças com autismo, que, em sua grande maioria, apresentam um brincar repetitivo, inflexível e restrito a determinados objetos e/ou materiais, busco colocar-me exatamente no lugar desse adulto que dá suporte, ora mais, ora menos; que propicia oportunidades de a criança expandir sua brincadeira; que imagina a partir da brincadeira dela possíveis desenrolares para o enredo; que é responsivo aos sinais que a criança dá de interação, por menores que possam ser; que interage com ela dentro do que ela traz para a sessão e/ou escolhe entre os materiais disponíveis; que leva para a sessão objetos que possam, de alguma forma, estar relacionados com o que ela se interessa e possibilitam uma expansão de tema/cena/interesse/enredo. E, a partir de posturas como estas e uma atenção constante, creio, possibilito que ela ocupe um lugar discursivo, na singularidade de sua história e na trama afetiva que ela nos permitir. 


\subsection{A criança e a brincadeira imaginativa: decorrências em diferentes dimensões}

Em uma das muitas reuniões que tive com o pai de Henrique, atendimento que será descrito com maior cuidado e informações no capítulo de análise, eu contei para ele que algo muito importante estava acontecendo nas sessões com seu filho: Henrique, além de brincar de fazer uma corrida com os carros (brincadeira repetida à exaustão), estava permitindo que eu introduzisse novos cenários, personagens e situações imaginárias. Contei para ele que em determinada sessão, após o filho jogar um dos carros no chão algumas vezes, eu comecei a fazer a voz do carro reclamando "Ai! Ai! Eu estou me machucando!!! Estou ficando todo amassado!", e propus que um outro carro fosse ao encontro deste para prestar ajuda, e levasse uma maleta de ferramentas de brinquedo. Henrique achou graça e me observou montando e fazendo a cena, e nas semanas que se sucederam, ele começou a pedir por essa nova brincadeira, esse novo enredo, jogando o carro no chão, dizendo "Ai! Ai!" e olhando para mim e para o carro que iria auxiliar como que solicitando a continuação da cena. Compartilhei com o pai essa pequena mudança na brincadeira de Henrique (permitiu minha participação, aceitou minha sugestão, quis repetir a brincadeira), que envolvia certa compreensão dele a respeito da situação e, principalmente, entusiasmo. Pareceu gostar da notícia na hora que contei; ele sorriu, mas em seguida me perguntou "mas por que é importante imaginar?".

Comecemos pelo auxílio que a psicologia do desenvolvimento pode nos dar, articulada às questões de posturas e princípios de ordem institucional discursiva. A brincadeira simbólica, imaginativa, possibilitaria que a criança distinguisse entre o que é real e o que é fantasia, o que não é real (Aronson; Golomb, 1999; Golomb; Kuersten, 1996). Permitiria que o pensamento do outro fosse reconhecido como igual ou diferente ao seu, conforme a brincadeira acontece (SCHWEBEL et al;1999); faria com que elas aprendessem habilidades sociais como dividir, compartilhar, esperar sua vez, cooperar, fazer acordos e confiar; "oferece oportunidades de atuar emoções negativas com o propósito da auto-regulação" (Singer; Singer, 2007, p.47); possibilitaria que elas expressassem seus sentimentos; ampliassem o vocabulário; fossem flexíveis, usando um objeto para substituir outro; aprendessem que há uma determinada sequência lógica na história que está inventando; favoreceria a "busca de alternativas não usuais, integrando o pensamento intuitivo" (Kishimoto, 2015, p.151); aguçaria os sentidos 
à medida que elas andam em seus triciclos ou puxam seus carrinhos, fingindo que esses são automóveis ou caminhões de entrega (Singer; Singer, 2007, p.48).

A brincadeira imaginativa é, então, parte fundamental no desenvolvimento de uma criança, pois ela amplia as possibilidades de interação com o outro e de entendimento deste outro, e auxilia no desenvolvimento motor e cognitivo. Além, é claro, de permitir organizar sentidos para as (e nas) brincadeiras. Isso nos interessa muito de perto, nas terapias que fazemos.

Num outro discurso, traremos a importância do brincar na terapia, e do imaginar em particular, no decorrer do capítulo 5. Antes, porém, faremos mais um percurso para tratar do assunto, agora, mais especificamente, sobre o tema do autismo. Assim, poderemos acompanhar como a área médica e as escalas diagnósticas caracterizam o TEA e o que dizem a respeito do desenvolvimento do brincar e da imaginação dentro deste quadro clínico. 


\section{NOTAS SOBRE O AUTISMO}

Neste capítulo apresentaremos algumas breves informações, notas, sobre o que caracteriza um quadro de autismo pelo critério médico (DSM-V, 2014), e algumas escalas mais utilizadas para corroborar o diagnóstico médico de TEA. Faremos isso nesta parte do trabalho para que o leitor se familiarize com eventuais termos que apareçam nas análises, e com o discurso médico e científico que permeia a fala de pais e profissionais quando se atende uma criança com esse diagnóstico.

E, muito além disso, para que o leitor possa, também, ter o contraponto com a perspectiva que aqui defendemos: a de que mesmo que repetida à exaustão, a experiência do brincar de uma criança com o diagnóstico de autismo é uma oportunidade de instituir com ela uma cena discursiva à qual ela reage, com consequências importantes para o seu desenvolvimento e para a transformação de seu quadro clínico.

\subsection{0 critério médico}

Para falarmos sobre o critério médico, faremos uso da descrição do Transtorno do Espectro Autista publicada pela $5^{\mathrm{a}}$ versão do Diagnostic and statistical manual of mental disorders (DSM-V $\left.\mathrm{V}^{11}, 2014\right)$, por ser o manual mais recente, e também por ser um recorte que já faz parte, muitas vezes, do discurso dos pais ao apresentarem seus filhos para profissionais da área da saúde.

Conforme o DSM-V (2014), o Transtorno do Espectro Autista faz parte dos Transtornos do Neurodesenvolvimento. Os critérios diagnósticos implicam "Déficits persistentes na comunicação social e na interação social em múltiplus contextos, (...) atualmente ou por história prévia” (AMERICAN PSYCHIATRIC ASSOCIATION, 2014, p.50), e

\footnotetext{
Padrões restritos e repetitivos de comportamento, interesses ou atividades, conforme manifestado por pelo menos dois dos seguintes, atualmente ou por história prévia (os exemplos são apenas ilustrativos, e não exaustivos; ver o texto): 1. Movimentos motores, uso de objetos ou fala estereotipados ou repetitivos (...). 2. Insistência nas mesmas coisas, adesão inflexível a rotinas ou padrões ritualizados de comportamento verbal ou não verbal (...). 3. Interesses fixos e altamente restritos que são anormais em intensidade ou foco (...). 4. Hiper ou hiporreatividade a estímulos sensoriais ou interesse incomum por aspectos sensoriais do ambiente (AMERICAN PSYCHIATRIC ASSOCIATION, 2014, p.50)
}

\footnotetext{
${ }^{11}$ Esta última versão tem recebido diversas críticas, mas não entraremos nesta discussão (MCPARTLAND, J.C. et al., 2012; HUERTA, M. et al., 2012)
} 
Esses sintomas teriam que aparecer de forma precoce no desenvolvimento da pessoa e deveriam gerar prejuízo significativo no funcionamento social, profissional, ou em outras áreas importantes da vida da pessoa. Além disso, eles não poderiam ser melhor explicados por deficiência intelectual ou atraso global do desenvolvimento.

Neste DSM $5^{\text {a }}$ edição revisada (2014), solicita-se que seja verificada a gravidade dos prejuízos na comunicação e nos padrões restritos e repetitivos de comportamento para que seja possível concluir o nível de gravidade do transtorno do espectro autista do paciente.

Os níveis de gravidade são: Nível 3, em que a pessoa necessitaria de "apoio muito substancial"; Nível 2, em que a pessoa necessitaria de "apoio substancial"; Nível 1, em que a pessoa necessitaria de "apoio" (AMERICAN PSYCHIATRIC ASSOCIATION, 2014, p.52).

Além disso, o médico deveria especificar se há ou não comprometimento intelectual concomitante; se há ou não comprometimento da linguagem concomitante; se o diagnóstico está associado a alguma condição médica ou genética conhecida ou a fator ambiental; se está associado a outro transtorno do neurodesenvolvimento, mental ou comportamental; se há catatonia. (AMERICAN PSYCHIATRIC ASSOCIATION, 2014, p.51).

O DSM V revisado (2014), ainda, traz algumas características diagnósticas que, como veremos a seguir, aparecem em algumas escalas utilizadas por pediatras, psiquiatras infantis, neuropediatras, e/ou psicólogos, como as características relacionadas à comunicação (que no DSM V são apresentadas como déficits) sendo: linguagem, reciprocidade emocional, comportamentos não verbais sociais; e as características relacionadas aos padrões restritos e repetitivos de comportamento (estereotipias).

Segue a descrição do manual quanto aos déficits de linguagem:

(...) variam de ausência total da fala, passando por atrasos na linguagem, compreensão reduzida da fala, fala em eco até linguagem explicitamente literal ou afetada. Mesmo quando habilidades linguísticas formais (p. ex., vocabulário, gramática) estão intactas, o uso da linguagem para comunicação social recíproca está prejudicado no transtorno do espectro autista. (AMERICAN PSYCHIATRIC ASSOCIATION, 2014, p.53)

Sobre os déficits de reciprocidade emocional,

Déficits na reciprocidade socioemocional (i.e., capacidade de envolvimento com outros e compartilhamento de ideias e sentimentos) estão claramente evidentes em crianças pequenas com o transtorno, que podem apresentar pequena ou nenhuma capacidade de iniciar interações sociais e de compartilhar emoções, além da imitação reduzida ou ausente do comportamento de outros. Havendo linguagem, costuma ser unilateral, sem reciprocidade social, usada mais para solicitar ou rotular do que para comentar, compartilhar sentimentos ou conversar. (AMERICAN PSYCHIATRIC ASSOCIATION, 2014, p.53) 


\section{Déficits em comportamentos de comunicação não verbal,}

(...) são expressos por uso reduzido, ausente ou atípico de contato visual (relativo as normas culturais), gestos, expressões faciais, orientação corporal ou entonação da fala. Um aspecto precoce do transtorno do espectro autista é a atenção compartilhada prejudicada, conforme manifestado por falta do gesto de apontar, mostrar ou trazer objetos para compartilhar o interesse com outros ou dificuldade para seguir o gesto de apontar ou o olhar indicador de outras pessoas. Os indivíduos podem aprender alguns poucos gestos funcionais, mas seu repertório é menor do que o de outros e costumam fracassar no uso de gestos expressivos com espontaneidade na comunicação. (AMERICAN PSYCHIATRIC ASSOCIATION, 2014, p.53,54)

\section{Déficits nas interações sociais:}

Pode haver interesse social ausente, reduzido ou atípico, manifestado por rejeição de outros, passividade ou abordagens inadequadas que pareçam pequenas, em quem costuma existir uma falta de jogo social e imaginação compartilhados (p. ex, brincar de fingir de forma flexível e adequada à idade) e, posteriormente, insistência em brincar seguindo regras muito fixas. (...) Pode existir aparente preferência por atividades solitárias ou por interações com pessoas muito mais jovens ou mais velhas. Com frequência, há desejo de estabelecer amizades sem uma ideia completa ou realista do que isso significa (p. ex., amizades unilaterais ou baseadas unicamente em interesses especiais compartilhados). (AMERICAN PSYCHIATRIC ASSOCIATION, 2014, p.54)

Sobre os comportamentos estereotipados ou repetitivos:

(...) incluem estereotipias motoras simples (p. ex., abanar as mãos, estalar os dedos), uso repetitivo de objetos (p. ex., girar moedas, enfileirar objetos) e fala repetitiva (p. ex., ecolalia, repetição atrasada ou imediata de palavras ouvidas, uso de "tu" ao referir-se a si mesmo, uso estereotipado de palavras, frases ou padrões de prosódia). Adesão excessiva a rotinas e padrões restritos de comportamento podem ser manifestados por resistência a mudanças (p. ex., sofrimento relativo a mudanças aparentemente pequenas, como embalagem de um alimento favorito; insistência em aderir regras, rigidez de pensamento) ou por padrões ritualizados de comportamento verbal ou não verbal (p. ex., perguntas repetitivas, percorrer um perímetro). Interesses altamente limitados e fixos, no transtorno do espectro autista, tendem a ser anormais em intensidade ou foco (AMERICAN PSYCHIATRIC ASSOCIATION, 2014, p.54)

Sobre as alterações sensoriais: Alguns encantamentos e rotinas podem estar relacionados a uma aparente hiper ou
hiporreatividade a estímulos sensoriais, manifestada por meio de respostas
extremadas a sons e texturas específicos, cheirar ou tocar objetos de forma excessiva,
encantamento por luzes ou objetos giratórios e, algumas vezes, aparente indiferença a
dor, calor ou frio. Reações extremas ou rituais envolvendo gosto, cheiro, textura ou
aparência de comida ou excesso de retrições alimentares são comuns, podendo
constituir a forma de apresentação do transtorno do espectro autista. (AMERICAN
PSYCHIATRIC ASSOCIATION, 2014, p.54) 
Para que todas essas características sejam devidamente investigadas e seja concluído o diagnóstico, a criança deve ser avaliada de forma clínica com relação à comunicação e linguagem, interação social, cognição, interesses restritos e comportamentos repetitivos. Com relação à forma orgânica-fisiológica de avaliação, ainda não há marcadores biológicos e exames específicos únicos para o autismo (MAGYAR; PANDOLFI, 2007), então, recorre-se a um dignóstico por exclusão, em que são feitos exames como eletroencefalograma (EEG), ressonância magnética (RNM), teste para Síndrome do X Frágil, erros inatos do metabolismo, teste do pezinho, sorologia para sífilis, rubéola e toxoplasmose, audiometria (Amorim, 2011) e exames genéticos como Array-AUT e MLPA-AUT (Instituto de Biologia, 2018).

\subsection{Escalas pré e/ou diagnósticas de TEA}

Algumas das escalas e dos protocolos mais utilizados para dar suporte ao pediatra quanto aos riscos e sinais de autismo em crianças, no modelo de rastreamento (screening), no Brasil, são: a M-CHAT (Losapio; Pondé, 2008); a Autism Behavior Checklist - ABC/ICA (Marteleto; Pedromônico, 2005); a Escala de avaliação de traços autísticos - ATA (Assumpção, Kuczynski, Gabriel, \& Rocca, 1999). Essas são escalas no formato de "check list", e possibilitam que o responsável pela saúde, juntamente aos pais, preencha de forma rápida, e auxilie, assim, a fazer uma hipótese diagnóstica e um encaminhamento ao neurologista e/ou psiquiatra infantil, caso seja necessário. Elas servem também para monitorar, posteriormente, o desenvolvimento da criança em relação aos sinais e sintomas relacionados ao autismo.

Quando a criança já foi encaminhada para o neuropediatra ou psiquiatra infantil, além dos exames laboratoriais solicitados para compor o diagnóstico, o médico costuma solicitar avaliações de profissionais clínicos, principalmente da área de neuropsicologia, psicologia e fonoaudiologia, sendo os testes e escalas mais conhecidos e utilizados (LINHARES, 2012; BORGES et al, 2008; MELLO, MIRANDA, MUZSKAT, 2006): Bayley III - escala de desenvolvimento para crianças entre 1 e 42 meses; Wisconsin Card Sorting Test - avaliação cognitiva (GRANT, BERG, 1948); NEPSY-II - desenvolvimento neuropsicológico (BROOKS et al, 2009); Autistic Diagnostic Observation Schedule II (LORD et al; 2012) - avaliação diagnóstica de autismo; Prova de Consciência Sintática (PCS) adaptada - linguagem (CAPOVILLA,A.G.; CAPOVILLA, F.C.,2006); Subteste Cubos da Escala Weschler - funções complexas ligadas a funções executivas (WESCHLER, 2002; FIGUEIREDO, 2002). 
A escala utilizada em nosso trabalho é a Autistic Diagnostic Observation Schedule II ADOS II (LORD et al; 2012) . Fizemos esta escolha pois além de ser uma escala considerada padrão ouro, isto é, tem validações em muitos países, é mundialmente utilizada e reconhecida pelo alto grau de confiabilidade (MOLLOY et al; 2011). Trata-se de uma escala de observação que permite que sejam avaliados os principais critérios apresentados no DSM-V: comunicação e linguagem, interação social, interesses restritos e comportamentos repetitivos.

Esta escala requer a aplicação por um profissional treinado e certificado que irá observar e propor algumas atividades lúdicas para a criança por, aproximadamente, uma hora, em um ambiente distinto do consultório médico com materiais padronizados.

Este instrumento é dividido em 5 módulos, sendo eles: Toddler Module, que abrange crianças de 18 a 31 meses; Module 1, que avalia crianças pré-verbais ou com palavras únicas; Module 2, que avalia crianças que falam frases curtas; Module 3, que avalia crianças e adolescentes fluentes na comunicação verbal; Module 4, destinado a adolescentes e adultos. A partir da observação na situação, revisão do vídeo e pontuação, é possível verificar, por comparação de idade e nível de linguagem, se a pessoa apresenta características nas áreas referidas acima (comunicação, linguagem...) em um grau que ela seja diagnosticada com TEA e, caso seja, em qual nível (níveis conforme o DSM-V: nível 1, sintomas leves associados ao autismo; nível 2, sintomas moderados associados ao autismo; nível 3, sintomas graves associados ao autismo).

O uso desta escala por nós não tem o objetivo de diagnosticar para, ou reafirmar e/ou refutar a hipótese médica. Por conta de ser um instrumento bastante criterioso e que abrange marcos importantes do desenvolvimento, principalmente em relação à interação social e comunicação, serve-nos como plano de fundo sobre como estava aquela criança em relação àqueles aspectos quando chegou ao consultório, e nos auxilia a pensar em estratégias de como ajudá-la a desenvolver-se melhor em relação a eles. Isto é, vamos buscar no que foi visto na situação de avaliação o que ela consegue fazer e, a partir daí, trabalhar com ela. Esse nosso olhar para avaliação favorece o contexto clínico porque nos ajuda a pensar por onde começar, e também a pensar a evolução clínica (uma vez que pode ser reaplicada com um intervalo mínimo de seis meses, uma vez que a criança esteja em tratamento), a bem de quem demanda.

Mais adiante será possível acompanhar com maior clareza o percurso terapêutico dessas crianças, e, a partir daí, compreender o uso da escala no ambiente clínico, terapêutico, onde o brincar é discurso prevalente. 


\subsection{No caminho da clínica: uma teoria da mente}

Em meio a aplicações de ADOS, sessões de terapia de crianças com diagnóstico de TEA, observações do desenvolvimento dessas crianças com o passar do tempo, e contato com médicos e outros profissionais da saúde que as atendem, iniciei uma busca paralela ao meu trabalho clínico e a esta pesquisa: o de tentar entender como foram feitos esses critérios médicos para este diagnóstico, e como foi feita a escala ADOS; quem pensou sobre essas características?; quais pesquisas foram feitas?; quando tudo isso aconteceu? Comecei pesquisando, então, as referências bibliográficas do DSM e da ADOS. Fui atrás de diversos estudos, e também me debrucei sobre as referências utilizadas por estes. Deparei-me, então, com certa frequência, com as pesquisas do psicólogo e pesquisador da University of Cambridge, Simon Baron-Cohen e seu grupo de trabalho.

Revisando a bibliografia deste autor ${ }^{12}$, verificamos que as pesquisas de Baron-Cohen e colegas descreveram os sinais e sintomas clínicos associados ao autismo tais como são utilizados tanto no DSM-V (2014) como na ADOS-2 (2012). E também conseguimos, a partir desses nossos estudos, levantar a hipótese de que as pesquisas do grupo de Baron-Cohen é que levaram a uma mudança da descrição no DSM sobre o autismo. No mínimo, "flagramos", aqui, a recorrência nos campos de pesquisa e da normatização psiquiátrica, o nascimento de um organizador do discurso sobre o autismo.

Veja, em 1985, Baron-Cohen, Uta Frith e Alan Leslie propuseram um conjunto de sintomas que estariam na origem, na caracterização primeira do autismo: anormalidades no desenvolvimento social, no desenvolvimento da comunicação e na brincadeira imaginativa (BARON-COHEN, LESLIE, FRITH, 1985). Naquela época os autores já supunham que tais sintomas poderiam estar relacionados a uma possível falha nos mecanismos da Teoria da Mente.

Conforme verificamos, tais características não apareciam ainda descritas no DSM da época, o DSM-III, de 1980. Estas mesmas não vieram a fazer parte na descrição da terceira edição revisada, DSM-III-R, de 1987. Passaram a caracterizar o quadro de autismo apenas no DSM-IV, de 1994, e continuam a caracterizar no atual DSM-V.

Esse histórico sobre a configuração de uma sintomatologia própria do autismo se faz importante, pela nossa análise, pelo seguinte: em algum momento da história, o autismo apareceu com características próprias, não mais associado ou em conjunto com descrições sobre

\footnotetext{
${ }^{12}$ Cabe destacar que, mesmo esta revisão bibliográfica, se visarmos em retrospectiva, percebemos nela as pegadas do pensar analiticamente: o lugar institucional desse tipo de estudo, nesse momento e contexto histórico da pesquisa sobre autismo.
} 
a esquizofrenia, e o momento em que isso aconteceu foi justamente após essa proposição de sintomas de Baron-Cohen, Frith e Leslie, e permanece até o presente.

Além disso, se verificarmos as datas das escalas e dos protocolos, todas, curiosamente, são posteriores à descrição desses autores. Isso nos leva a pensar que foi, então, a partir da publicação de 1985 de Baron-Cohen, Leslie e Frith, que passaram a ser produzidas escalas e testes que buscavam verificar essas características para concluir um diagnóstico de autismo (vide data das principais escalas citadas no item anterior, 3.2).

Saber disso poderia soar apenas uma curiosidade sobre o surgimento do diagnóstico. Mas não é. Saber disso é, também, o que nos possibilita adentrar o pensamento deste pesquisador e sua equipe, e entender melhor, talvez, os motivos dos critérios para TEA e, com isso, poder pensar na criança que chega ao consultório com esse diagnóstico, com mais liberdade. Possibilita-nos, na situação concreta caracterizada descritivamente, levantar hipóteses no nosso trabalho cotidiano e acalmar nossa vontade de saber.

Conforme Baron-Cohen, a preocupação dos adultos com os olhos e com o olhar datam de longo tempo; uma das primeiras brincadeiras que os adultos fazem com as crianças pequenas é de cobrir e descobrir a região dos olhos e a criança sorrir quando os olhos do adulto reaparecem (cadê-achou), como bem demonstrado por Bruner (1983) e exposto no capítulo anterior.

Baron-Cohen acrescenta, para além da preocupação dos adultos, a fascinação que os olhos e o olhar provocam nas crianças, uma vez que carregam expressões faciais em conjunto:

\begin{abstract}
Meu palpite é que nós adultos estamos conscientes, em algum nível, não apenas do quão importantes são os olhos para nós, mas também o quanto os bebês parecem atraídos por eles. Eles nos vêem piscando, e imitam isso (Meltzoff, 1990), eles seguem a direção do nosso olhar (próximo dos 9 meses). Nossos olhos dão a eles uma pista da nossa interpretação dos eventos, ao nosso olhar é comumente carregado de uma expressão emocional facial (de interesse, prazer, medo, surpresa, desgosto, raiva, etc). (BARON-COHEN, 1997, p.119, tradução nossa ${ }^{13}$ )
\end{abstract}

Sabemos, porém, por tudo o que já foi dito anteriormente, que crianças com autismo apresentam certa dificuldade em acompanhar o olhar adulto, e que com 18 meses já é possível

\footnotetext{
${ }^{13}$ My guess is that we adults are aware, at some level, not only of how important the eyes are to us but also of how infants seem attracted to them. They watch us blinking, they imitate this (Meltzoff, 1990), and they turn to follow our Direction gaze (from 9 months or so). Our eyes give them a clue to our interpretation of events, since our gaze is usually embedded within an emotional facial expression (of interest, pleasure, fear, surprise, disgust, anger, etc). (BARON-COHEN, 1997, p.119)
} 
observar um déficit generalizado na atenção compartilhada (BARON-COHEN, ALLEN, GILLBERG, 1992).

Confome Baron-Cohen (1997), isso aconteceria por conta de o transtorno do espectro autista envolver um déficit central em relação ao que ele chama de "mindreading", e possível co-existência de outros déficits (p.137). Dentro da formulação de sua teoria da mente, que discorreremos com mais detalhes, a seguir, esse déficit ocorre devido a um comprometimento consistente do mecanismo de atenção compartilhada (Shared-Attention Mechanism - SAM). (p.139).

Antes de nos aprofundarmos na descrição sobre a teoria da mente, faz-se necessário aqui um esclarecimento: nosso trabalho, conforme a AID, não buscará aplicar ou justificar nenhuma relação ou comportamento (seja por parte da criança ou por parte do adulto) por esta ou qualquer outra teoria. No caso, a teoria da mente de Baron-Cohen está sendo aqui apresentada como uma forma de mostrar ao leitor uma teoria que instrumentaliza a posição desta pesquisadora e terapeuta, o meu lugar, e que aparece de forma indireta, por meio de algumas das características avaliadas pela Autism Diagnostic Observation Schedule (ADOS).

Baron-Cohen começa seu trabalho intitulado de Mindblindness - An essay on autism and theory of mind (1997), definindo mindreading como a capacidade de imaginar e/ou representar estados mentais que nós ou outras pessoas possam ter. Isto é, nossa capacidade de ver uma cena, por exemplo, de alguém entrando em um quarto, dando uma volta e saindo, e imaginar/inferir/supor/atribuir os motivos e as intenções dessa pessoa para essa sequência de ações. Nas palavras do autor, "It is our natural way of understanding the social environment" (p.04).

Mindreading pode assumir diversas funções, como compreensão do contexto social, predizer comportamentos, interação social e comunicação. Nesse ponto, o autor faz uma distinção entre a produção de fala, que não envolve mindreading, e o diálogo:

Compreendido desta maneira, o diálogo se torna muito mais que uma produção de fala: revela-se como algo intrinsecamente ligado ao uso de habilidades de mindreading. (...) E em termos evolutivos, o valor de mindreading na comunicação, está relacionado a habilidade de ir além das palavras e ouvir a intenção do falante, o que pode permitir àquele que ouve, julgar se o falante está sendo enganoso ou genuíno. (BARON-COHEN, 1997, p.29, tradução nossa ${ }^{14}$.)

\footnotetext{
${ }^{14}$ Dialogue understood in this way becomes much more than the production of speech: it is revealed as intrinsically linked to the use of mindreading skills. (...) And in terms of the evolutionary "fitness" value of mindreading in communication, it is clear that an ability to go beyond the words hear to the speaker's intention would allow the listener to judge whether the speaker was being deceitful or genuine. (BARON-COHEN, 1997, p.29)
} 
Apesar de mindreading ser descrito como natural, algumas pessoas prescindem dessa capacidade. Por conta disso, Baron-Cohen irá apresentar um modelo de desenvolvimento neuropsicológico de mindreading, e levantará hipóteses sobre em quais partes esse modelo pode apresentar falhas e, com isso, produzir mindblindess.

Conforme o autor, teríamos 4 mecanismos inatos, biológicos e modulares (p.12) que, juntos, fundamentariam essa capacidade de compreender e predizer o comportamento de outra pessoa, por menos pistas de comportamento que tenhamos dela (p.26). Não seriam os únicos mecanismos, mas talvez os mais diretamente relacionados a mindblindness.

O primeiro seria o Intentionally Detector (ID); o mecanismo mais básico para a capacidade de mindreading, e teria início na infância. A ele estaria atribuída a função de percepção, que interpretaria estímulos de movimento em termos de estados mentais de vontade e desejo. Esse mecanismo seria ativado quando qualquer entrada de percepção (visão, tato, audição) identificasse algo como agente do movimento.

Por exemplo:

Se você vê um animal se mexendo, pode ser uma ameba, um rato ou o primeiro ministro britânico, tudo a que você precisa se referir para começar a interpretar seus movimentos são esses dois estados mentais básicos. Eles permitem que você interprete seus movimentos em termos de: se seu objetivo é ir até lá, ou, se ele quer pegar o queijo, ou, se ele quer se distanciar disso, ou se ele quer ter poder. (BARONCOHEN, 1997, p.33, tradução nossa ${ }^{15}$.)

O segundo mecanismo seria o Eye-Direction Detector (EDD); mecanismo especializado do sistema visual humano que possuiria 3 funções: 1) detectar a presença de olhos e/ou estímulos oculares; 2) avaliar se os olhos de outro organismo estão direcionados para a pessoa ou para outra coisa; 3 ) interpretar o olhar como ver, isso é, codificar o contato ocular mútuo como "ele me vê, eu vejo ele".

O autor cita Stern (1985) para dizer que esse mecanismo está presente na criança de forma precocemente matura, e é o que permite que ela faça ou interrompa o contato visual, bem como que ela regule a quantidade de contato visual que lhe é confortável por determinado tempo. Cita, também, a descrição de Bruner (1983) sobre a brincadeira "cadê-achou" para dizer sobre sua importância, também, em exercitar o mecanismo EDD da criança.

Sobre esses dois mecanismos, Baron-Cohen conclui:

\footnotetext{
${ }^{15}$ If you see an animal moving, be it an amoeba, a mouse or a British prime minister, all you need to refer to in order to begin to interpret its movement are these two basic mental states. They allow you to interpret its movement in such terms as: Her goal is to go over there, or, It wants to get the cheese, or, It wants to get away from his, or He wants power. (BARON-COHEN, 1997, p.33)
} 
Ambos os mecanismos estão disponíveis desde muito cedo na infância. Isso significa que nós temos um bebê que lê o comportamento em termos de um pequeno conjunto de estados mentais (objetivo, desejo, e aquilo que ele vê). Embora isso possa te levar muito longe, esses mecanismos não permitem que você represente que você e mais alguém(...) estão respondendo ao mesmo objeto ou evento. E ainda, isso é exatamente aquilo que alguém poderia precisar para poder comunicar sobre uma realidade compartilhada, e sentir que você e a outra pessoa estão focadas e pensando sobre a mesma coisa. (BARON-COHEN, 1997, p.43-44, tradução nossa ${ }^{16}$.)

O terceiro mecanismo seria Shared-Attention Mechanism (SAM), e teria a função de criar representações em tríade (agente, própria pessoa e objeto). Seria, por exemplo, você olhar para um objeto e ao olhar para uma outra pessoa, vê-la olhando para o mesmo objeto. Tendo em vista que SAM recebeu a informação através do monitoramento da direção do olhar de outra pessoa, pode-se dizer que SAM recebe informação de EDD. E, se considerarmos que EDD leu o olhar de outra pessoa como vontade/objetivo, é porque ID serviu como saída para EDD.

Baron-Cohen nos dá três exemplos de como SAM funciona em crianças pequenas, por meio de estudos de colegas pesquisadores. O primeiro é sobre a representação em tríade, e o segundo sobre como essa representação permite o desenvolvimento do apontar e mostrar:

\begin{abstract}
Primeiro, o monitoramento do olhar (Scaife and Bruner, 1975; Butterworth, 1991) é visto em bebês por volta dos 9 meses. Neste fenômeno, o bebê se vira para a mesma direção que outra pessoa está olhando, e então mostra uma alternância no olhar, verificando algumas vezes para ter certeza (ao que parece) de que a outra pessoa e ela, estão ambas olhando para a mesma coisa, estabelecendo então uma atenção visual compartilhada sobre o mesmo objeto.

Segundo, por volta da mesma época, os bebês começam a produzir o tão conhecido gesto protodeclarativo de apontar (Bates et al. 1979) - que é apontar com o dedo indicador esticado para algo adiante, para ter certeza (ao que parece), que a outra pessoa se virou para a mesma coisa que o bebê está olhando para. (...) O bebê também traz objetos para a linha de visão de outra pessoa. (Lempers et al. 1977). (BARONCOHEN, 1997, p.48, tradução nossa ${ }^{17}$.)
\end{abstract}

\footnotetext{
${ }^{16}$ Both of these mechanisms are available very early in infancy. This means that we have an infant that, so far, can read behavior in terms of a small set of mental states (goal, desire and seeing). (...) Though that gets you pretty far, these mecanisms do not allow you to represent that you and someone else (...) are both attending to the same object or event. And yet that is exactly what one would need in order to be able to communicate about a shared reality and to feel that you and the other person are focusing on and thinking about the same thing. (BARON-COHEN, 1997, p.43-44)

${ }^{17}$ First, gaze monitoring (Scaife and Bruner, 1975; Butterworth, 1991) is seen in infants from around 9 months or so. In this phenomenon, the infant turns in the same direction that another person is looking at and then shows gaze alternation, checking back and forth a few times to make sure (as it appears) that it and the other person are both looking at the samething, thus establishing shared visual attention on the same object.

Second, around the same time, toddlers begin to produce the so called protodeclarative pointing gesture (Bates et al. 1979) - that is, pointing with an outstretched index finger at and forth a few time to make sure (as it appears) that the other person has turned to look at the same thing the toddler is looking at. (...) A toddler also brings objects into another person's line of regard (Lempers et al. 1977). (BARON-COHEN, 1997, p.48)
} 
O terceiro exemplo é sobre como as crianças inferem estados mentais a partir do direcionamento do olhar do outro. Ele fala sobre um estudo feito com Wendy Phillips e Mike Rutter em 1992 com crianças de 9 a 18 meses, em que eram apresentadas ações ambíguas (segurar uma de suas mãos enquanto a criança estava envolvida em uma atividade manual, e oferecer-lhe um objeto e retirá-lo de seu alcance quando a criança estava indo pegá-lo) e não ambíguas (dar o objeto mostrado para a criança), e a maioria das crianças, após a ação ambígua, olhavam para o rosto do adulto, demonstrando, assim, que quando o objetivo da ação era incerto, elas buscavam informação nos olhos das pessoas (PHILIPPS, BARON-COHEN, RUTTER, 1992).

O quarto e último mecanismo seria Theory-of-Mind Mechanism (ToMM), que teria dupla função: representar os estados mentais epistemológicos (fingir, pensar, saber, imaginar, sonhar, adivinhar, decidir) e agrupar o conhecimento mental (de volição, percepção e epistemológico) em uma teoria aplicável.

Este último mecanismo recebe informações do ID e EDD, integrando as informações em uma teoria aplicável, e também recebe as representações tríades do SAM e as transforma em representações mentais.

Conforme Baron-Cohen (1997), este modelo de desenvolvimento pela teoria da mente supõe 3 fases, sendo a primeira do nascimento aos 9 meses, que todos os bebês têm o ID e as funções básicas do EDD e a única forma de representação é díaca. A segunda fase iria dos 9 aos 18 meses, e é quando SAM começa a ser desenvolvido. Nesta fase é possível estabelecer representações em tríade que produzem atenção compartilhada, e é possível que a direção do olhar seja lida nos termos dos estados mentais básicos. A terceira fase é quando ToMM aparece, e ela é marcada pelo surgimento da brincadeira imaginativa. A criança começa a apreciar os estados mentais epistemológicos dela e do outro, "começando com o estado mental de 'fingir' e progredindo nos próximos dois anos para os importantes estados mentais de 'saber' e 'acreditar'. A criança faz isso por meio da construção das representações mentais" (BARONCOHEN, 1997, p.56, tradução nossa $\left.{ }^{18}\right)$.

Até aqui, completamos nossa descrição de sua teoria para que a partir de agora possamos adentrar ao modo como Baron-Cohen enxerga o autismo e os pontos relacionados a esta.

Seguimos.

\footnotetext{
18 "starting with the mental state 'pretend' and progressing over the next two years to the importante mental states of 'knowing' and 'believing'. The child does this by building M-Representations" (BARON-COHEN, 1997, p.56).
} 
O que acontece com as crianças com autismo em relação aos mecanismos da Teoria da Mente?

Conforme o autor, essas crianças apresentam ID intacto, isto é, apresentam estados mentais volitivos inalterados: elas usam a palavra "quero" espontaneamente em seu discurso, identificam desejos e ações de outras pessoas; distinguem animação; e entendem que desejos provocam emoções (p.63).

Elas também apresentam EDD intacto, pois são capazes de detectar em uma fotografia quando a pessoa está olhando para ela; de interpretar a direção do olhar de outra pessoa no sentido da direção e o foco/objeto para o qual a pessoa está olhando; e elas usam o termo "ver" em seu discurso espontâneo (p.64).

Já em relação a principal função de SAM, que é de construir uma representação em tríade (especificar e verificar se ela mesma e o outro estão atentos ao mesmo objeto), a maioria das crianças com autismo não consegue responder (p.64/65). Isto é, elas não conseguem apresentar as principais formas de atenção compartilhada: não monitoram o olhar de outra pessoa, não usam gestos "protodeclarativos" (como o apontar com o dedo, por exemplo) para dirigir a atenção do outro para algo de interesse em comum, e não mostram objetos com a intenção de compartilhar interesse (p.66;68).

Em relação ao mecanismo da teoria da mente (ToMM), nessas crianças, ele também aparece como alterado. Conforme Baron-Cohen, as crianças com autismo conseguem sequenciar histórias que envolvam uma relação física causal, mas não conseguem entender e sequenciar histórias que envolvam estados mentais e crenças diferentes das delas. Elas apresentam dificuldade em entender fingimentos; e isto estaria diretamente ligado à dificuldade em brincar espontaneamente de faz-de-conta, afinal, "para entender o fingimento você precisa entender que fingir é diferente de não fingir" ${ }^{\prime 19}$ (p.76).

Com o modo de funcionamento do mecanismo da teoria da mente (ToMM) alterado, alguns pontos-chave da compreensão dessas crianças sobre as demais pessoas e o mundo à sua volta também ficam alterados, gerando algumas dificuldades. Por exemplo: (a) a entender que, ao verem algo, elas sabem alguma coisa sobre esse algo (ao verem que alguém escondeu uma moeda, elas sabem que a moeda está escondida) (BARON-COHEN, GOODHART, 1994); (b) a reconhecer expressões faciais além de "triste" e "feliz", como, por exemplo, surpreso e/ou assustado (BARON-COHEN, SPITZ, CROSS, 1993); (c) a compreender que determinada situação provoca determinada emoção, apesar de não conseguirem prever a emoção, tendo em

${ }^{19}$ Tradução livre. "in order to pretend, one must understand how pretending is diferente from not pretending" 
vista o que pensam sobre a situação (BARON-COHEN, 1991); (d) a diferenciar entre o que é mental do que é físico (BARON-COHEN, 1989). A maioria das crianças parece ser dominada pela percepção, sem possibilidade de utilizar os recursos do conhecimento sobre o objeto (por exemplo, se uma pedra parece um ovo, então é um ovo), e, por conta de conseguir considerar apenas as próprias percepções e sensações, e não também a dos demais, o mundo parece pouco previsível e muito assustador.

Em resumo, essas crianças são capazes de fazer registros sobre os outros e sobre si, mas não conseguem relacionar esses registros, fazer com que se comuniquem, e usá-los em favor de estabelecer uma relação tal qual conhecemos com as demais pessoas.

Se Baron-Cohen, com isso, descreve os sintomas do autismo ou os explica, não é o que importa para nós. Não iremos justificar ou explicar as ações e reações dos pequenos atendidos por essa óptica. Apenas guardaremos na cabeça, como mais um registro sobre o autismo que poderá nos ajudar a levantar hipóses no trabalho cotidiano, dependendo da situação, e seguiremos em direção ao atendimento. 


\section{SOBRE O MÉTODO}

“E, nisso tudo, brincar é preciso. Falar não é, necessariamente, preciso. Até porque, por suposto, pelo modo como o apresentamos, o brincar é discurso-ato." (Guirado, 2018, p.138).

Henrique tem 7 anos. Um menino alto e magro, com bastante energia. Bate palmas, sorri, fala alto. Ele chegou com essa idade ao meu consultório, após uma série de intervenções pelo método ABA. Segundo a mãe, Henrique não aguentava mais fazer "aquelas atividades de cor”, já estava entediado.

Ela o apresenta como tendo o diagnóstico de autismo e sendo verbal. Sua fala é bastante pautada em repetições de falas de desenhos animados e, vez ou outra, adequa-se ao contexto imediato.

Desde as primeiras sessões, Henrique chegava na sala de atendimento, agachava-se de frente para a prateleira de carrinhos, elegia um e o observava minuciosamente, em silêncio absoluto. Ele fazia uma espécie de perícia com o carro: aproximava dos olhos, afastava, verificava as rodas girando-as rapidamente e devagar com as mãos, passava a mão no capô, demonstrando muita atenção a todos os detalhes. Depois, fazia o mesmo com um segundo carrinho, e só então começava a brincar.

Muitas das vezes em que vi Henrique fazendo isso, tentei conversar com ele sobre o que estava vendo, tocando, avaliando. Henrique, via de regra, não respondia para mim quando lhe perguntava algo neste momento, nem comentava o que estava pensando enquanto fazia isso.

Em uma das primeiras conversas com os pais, quando comentei sobre esse comportamento de Henrique, eles disseram que era algo corriqueiro, cotidiano, que o menino fazia isso em casa também, com vários carros.

Após seis meses de atendimento, sem nenhuma pista concreta sobre o que seria aquela observação tão atenta e precisa dos carros, o pai de Henrique pediu para que eu fosse observálo na casa da avó, com quem ele ficava no período da manhã, antes de ir para a escola. A demanda do pai era a de que eu a auxiliasse nas dificuldades que ela pudesse ter com o neto.

A observação foi feita, e quando voltei, em outro dia, para dar uma devolutiva à avó de Henrique, notei que no quarto em que ele ficava brincando havia um iPad ligado, para o qual ora ele olhava, e que ora deixava em algum canto, indo brincar com os carrinhos. Dei uma olhada na tela, e vi que estava passando um vídeo sobre um carro que ele adora, do filme Carros (Disney/Pixar). Não era um vídeo qualquer. Era um vídeo em que aparecia somente uma mão 
movendo o carro com lentidão e delicadeza, explicando, em inglês, cada parte do carro, o tipo de pintura, as formas, o modelo, etc.

No mesmo dia, mais tarde, Henrique veio ao consultório e, como sempre, agachou-se em frente à estante e pegou um carro para observar atentamente. Nesse momento, eu sentei ao lado dele e disse "Henrique, eu acho que descobri. Eu acho que descobri porque você fica assim olhando os carros, todos os detalhes...”. Ele parou, olhou para mim, e eu continuei “... hoje na sua avó você estava vendo um vídeo de uma mulher falando sobre um carrinho. Ela mostrava todas as partes dele, ia comentando sobre a roda, a cor, o modelo." E ele voltou a observar o carro. Então eu prossegui dizendo "Eu acho que na sua cabeça, você deve ficar comentando coisas iguais às que ela comenta quando você vê um carrinho desse jeito. Deve ter uma voz aí dizendo sobre a roda, o capô, a pintura..” Mal tinha terminado de completar a frase, Henrique deu uma gargalhada deliciosa olhando para o carro. Virou-se para mim e disse "Descobriu! Descobriu!" e continuou rindo. Em seguida, deitou com a cabeça nas minhas pernas. Olhou para o teto, olhou para mim, gargalhou novamente e me disse "Descobriu!".

Temos aí um contexto e uma cena. Dentro desta cena, temos um menino, literalmente paciente, que fazia uma brincadeira que era incompreensível para a terapeuta, até que ela pôde observá-lo, em outro ambiente ver ao que assistia; imaginar que ele poderia estar reproduzindo a cena, assim como ele reproduz as falas de desenhos, e dizer isso para ele. Dizer isso para ele foi a pedra de toque: foi reconhecer que havia uma fala dele que, para ele, movia a sessão. Ao dizer de sua descoberta, a terapeuta apostou na capacidade de Henrique para ouvi-la e para responder de algum jeito à hipótese que ela tinha criado; e qualquer que fosse sua resposta, seria legítima. Ainda, a terapeuta apostou que o que aparentava isolamento na comunicação poderia ser, naquele exato momento, uma comunicação com suas lembranças e com a parceira de atividade, que deveria adivinhar, descobrir a sua parte na conversa, já que o simples fato de poder exercer o diálogo íntimo, tinha sua suficiência. No fundo, ele também concedeu um espaço para que sua terapeuta-parceira achasse seu lugar. E, vibrou com isso! Preferiu, até, essa companhia real, que tinha um colo, àquela virtual, que tinha uma voz. Por quanto tempo não se pode dizer. Por quais razões também não. Mas isso pouco importa para o momento. Importa mais que algo se rompeu e se moveu. Os sentidos e direções, naquele momento, ficaram por se configurar.

Não se buscou, em nenhum momento, categorizar seu comportamento/sua brincadeira, e/ou classificá-lo. Menos ainda interpretá-lo. O foco não era no nome que eu viesse a dar para o comportamento do paciente, nem o sentido que eu desse a uma colocação do paciente. $\mathrm{O}$ foco 
era, sim, a possibilidade de ele responder a uma hipótese ao modo de uma "construção a dois" de um sentido para a sua ação, um ato analítico, que difere de interpretação ${ }^{20}$. Mais adiante trataremos dessa diferença.

Desse modo, como afirmamos acima, Henrique tinha um lugar reconhecido em cena. Ele mesmo o assumiu ao dizer "Descobriu!", mas poderia apenas ter gargalhado. O sentido da resposta seria entendido do mesmo jeito que foi com a palavra-falada. E, num mesmo ato, configurou-se um lugar de parceria a esta terapeuta no jogo imaginário, e solitário, onde só Henrique e seu carro e sua voz pareciam compor a cena. Assim se foi possível concretizar a interlocução, o prazer e a brincadeira partilhada, em cena aberta e a olhos vistos...

Henrique, ao brincar de ver os carros minuciosamente, conta, silenciosamente, de uma experiência que tem e vive (a de ver, e gostar de ver, demonstração de carrinhos em vídeos). Seu ato, portanto, é um discurso. E um brincar assim acompanhado por mim, teve um efeito surpreendente para nós dois.

Marlene Guirado (2016), em um texto em que trata particularmente do acolhimento de crianças e adolescentes em abrigos, nos apresenta um respaldo metodológico importante ao dizer que é a narrativa da própria história que constitui um lugar discursivo para a criança. Isso porque, conforme a autora,

(...) o âmbito da estratégia de pensamento da AID nos permite afirmar, exatamente pelas interfaces que o constitui, que a singularidade afetivo-imaginária das crianças, ao ingressarem nas casas de acolhimento, organiza-se como uma espécie de registros em rede. Algo à moda do que Freud chamou de Bloco Mágico, que não fixa fatos tal como são isoladamente vividos, mas em composições que modificam sempre as novas experiências, em função das anteriores, dispondo assim o terreno flexível e móvel para novos registros... (GUIRADO, M., 2016, p.167-168)

E, como ela bem coloca,

As narrativas livres, aquelas em que (as crianças) emprestam, aos personagens e aos enredos, suas próprias cenas e lugares, são de longe, os recursos mais produtivos e os jogos mais imaginativos concretos de que poderiam dispor para reconstruir suas próprias histórias.

$\mathrm{O}$ adulto? É aquele que, na cena viva com a criança, é o acompanhante e o provocador dessa voz que diz de si. É, sem dúvida, um interlocutor privilegiado. (GUIRADO, M., 2016, p.169)

\footnotetext{
${ }^{20}$ Conforme Guirado (2018), o diferenciador entre análise e interpretação "é a consideração do contexto para a produção do sentido. (...) como a condição de enunciação, constituinte de qualquer ato de fala, que responde pela geração de sentimentos, conflitos e expectativas nos interlocutores. (...) há um 'enlaçamento texto/contexto', nos dispositivos sociais discursivos (gêneros de discurso) que produzem e acomodam expectativas entre atores numa determinada prática institucional.” (GUIRADO, 2018, p.154)
} 
Como se pode observar, iniciamos este capítulo "Sobre o Método" por um relato sobre um atendimento em meu consultório e dele evoluímos para um comentário sobre o artigo de Guirado, que tangenciava o relato clinico, mas que tratava de outro contexto: o de crianças em condição de acolhimento institucional. $\mathrm{O}$ fio condutor foi a demonstração de um conceito fundamental para a estratégia de pensamento que instrumenta esta Tese de Doutorado: o de discurso.

Com lugar privilegiado e articulado a outros, como o de instituição, análise e subjetividade, o termo discurso é um importante organizador do modo de pensar/fazer uma pesquisa como a nossa. De todos, trataremos no item que se segue, no entanto, por ora, deve-se proceder a uma espécie de "desencapamento" de tal fio.

Entendemos discurso como ato; e, ato, não é, aqui, necessariamente um comportamento conforme se define na psicologia. É, sim, um conjunto de procedimentos institucionais que dispõem lugares, nas relações que estabelecemos, nós, atores de uma determinada prática social. Por decorrência, o discurso é prática institucional, que se exerce. Como tal, está aquém e além do uso da palavra falada. Pode envolvê-la na relação de clientela, por exemplo, como parte constitutiva dos rituais característicos de uma comunidade discursiva, a gerar expectativas mútuas de respostas entre os parceiros numa interlocução. Veja-se, mais à frente, quando apresentarmos o conceito de Gênero de Discurso. Entretanto, o próprio falar é tomado, neste âmbito conceitual, como ato (ato de fala), o que, de certa forma, embora não definitivamente, põe em suspenso os conteúdos específicos da fala, para garantir os efeitos do falar na cena discursiva, na direção dos procedimentos.

Ora, é surpreendente acompanhar o que acontece quando funcionamos com essa compreensão de discurso: o inesperado reorienta os próximos passos e entendimentos no fazer/falar. Aqui está o caráter exemplar do relato clínico com que iniciei este item. Ele mostra, no mesmo ato, o efeito do recorte conceitual-metodológico que nos permitia entender, pela organização de certas atenções, a cena concreta que se configurava. Mas, sobretudo, mostra que, ao assim agir, não acionamos, de primeira, interpretações com base em teorias (como as psicanalíticas, a título de exemplo) sobre objetos, mesmo que estes sejam tão impalpáveis como o inconsciente e a sobredeterminação do psiquismo que o caracteriza e, mesmo que aquelas tenham uma coerência indiscutível em sua trama. A questão que se coloca aqui é a de que pode ocorrer uma antecipação de sentidos que, ao invés de singularizar, generaliza o que acontece numa sessão, para além da criança e seus "motivos". 
O caráter casual do discurso se impõe, ou melhor, é constituinte, do levantamento de hipóteses contextuais que abarcam o caráter analítico do trabalho. Ainda que faça parte desse casual uma observação que a terapeuta tenha feito fora do setting clínico, como foi o caso do atendimento de Henrique.

E isto se coloca, a rigor, como uma ética da intervenção concreta e da pesquisa. Vejase, na citação de Guirado, sobre o direito à narrativa da própria história das crianças que sofrem um corte na vida cotidiana, com seus parceiros habituais, e é acolhida num abrigo. A possibilidade de ela contar suas experiências até então, bem como as expectativas que a mudança gerou, no limite da consciência e da imaginação, é ocasião de apropriação, em algum nível, dessa sua história. A decisão de assim proceder, por parte do profissional/adulto em cena, abre esse campo de possibilidades na relação básica das instituições de acolhimento. Supõe a compreensão de discurso como ato, dispositivo, acontecimento.

Sigamos agora com uma abordagem aos outros termos e à relação entre eles, numa análise assim institucional do discurso.

\subsection{O método como estratégia de pensamento}

A Análise Institucional do Discurso é uma estratégia de pensamento desenvolvida na fronteira com a sociologia da Análise de Instituições Concretas de Guilhon-Albuquerque, a linguística da Análise Pragmática do Discurso de Dominique Maingueneau e as ideias de Michel Foucault (Guirado, 2010), para a produção de pesquisas e outros trabalhos em psicologia. Ela é constituída a partir do estabelecimento de conceitos que são "exteriores” a ela, sendo os mais importantes: instituição, discurso, análise e sujeito/subjetividade.

Antes de entrarmos em cada um desses conceitos para elucidá-los ao leitor, é necessário esclarecer que método, pela AID, refere-se ao como nós pensamos, formado pelo nosso campo conceitual. É o que nos orienta desde quando pensamos a pesquisa até sua realização e finalização. E por campo conceitual, referimo-nos ao que Foucault chama de "necessidades conceituais", que é diferente de teoria.

(...) Uma vez que uma teoria assume uma objetivação prévia, ela não pode ser afirmada como uma base para um trabalho analítico. Porém, esse trabalho analítico não pode proceder sem uma conceituação dos problemas tratados, conceituação esta que implica um pensamento crítico - uma verificação constante.

A primeira coisa a verificar é o que eu deveria chamar de "necessidades conceituais". Eu compreendo que a conceituação não deveria estar fundada numa teoria do objeto - o objeto conceituado não é o único critério de uma boa conceituação. Temos que 
conhecer as condições históricas que motivavam nossa conceituação. Necessitamos de uma consciência histórica da situação presente. (FOUCAULT, 1995, p.232)

Essa diferenciação é fundamental para a estratégia de pensamento da análise institucional do discurso quando instrumenta, como fizemos aqui, recursos que vêm da psicologia do desenvolvimento e outros, de modo descritivo, não como objetos previamente definidos, prontos à disposição do terapeuta, mas como ocasião de análise em contexto (estes sim, carecendo de constantes definições para que se possa levantar qualquer hipótese analítica).

Feitos esses esclarecimentos, podemos prosseguir.

O conceito de instituição na AID é o que explicitamos, na apresentação desta tese, de Guilhon-Albuquerque. São práticas sociais que se repetem e, nessa repetição, legitimam-se e se naturalizam, desconhecendo-se sua condição de instituídas.

\begin{abstract}
O mais importante nessa compreensão de instituição é que ela nos coloca, na qualidade de agente ou clientela, como atores da cena. É a nossa ação que faz a instituição. Inclusive, no que diz respeito aos efeitos de reconhecimento e desconhecimento. (...) Além disso, toda instituição constitui um objeto (imaterial, impalpável): é aquilo (ou a relação básica) em nome de que ela se faz, e cujo monopólio é reivindicado numa delimitação de âmbito de ação com outras instituições. (...) Uma relação de poder, portanto, um jogo de forças poder/resistência, que não se dá senão no e pelo discurso. (Guirado, 2018, p.19)
\end{abstract}

Com este conceito consideraremos a relação terapêutica como relação entre atores que, no exercício de seus lugares, garantem posições de enunciação e, com isso, criam e recriam cenas, na sombra do discurso e do interdiscurso de um determinado contexto social.

Mas, o que é discurso para AID? Discurso, aqui, não é sinônimo da palavra que é dita por alguém; discurso é entendido como o modo como alguém enuncia algo "e, até certo ponto, como cena enunciativa, que posiciona personagens, que distribui lugares e expectativas em torno desses lugares, como diria o linguista e analista de discurso, Dominique Maingueneau" (Guirado, 2018, p.20)

Esse modo de enunciar faz parte do que Maingueneau chama de gênero discursivo (GD). Isto é, “(...) a condição de possibilidade para que a comunicação aconteça, com determinadas ações que possam, então, ser desencadeadas em função da expectativa em relação ao outro (...) O gênero discursivo é o que, em linhas gerais, responde pelo contexto" (Guirado, 2015, p.113).

E, na perspectiva do gênero do discurso, há um nível de análise chamado cenografia, que "é o plano mais imediato da relação que caracteriza o GD. É seu nível mais concreto e complexo, porque é o nível da relação face-a-face que reconstrói o GD” (Guirado, 2015, p.113). 
A cenografia é esse contexto que se constrói no interior de um contexto mais amplo, o GD. E, bem, o discurso está no (e constrói) o contexto...

\begin{abstract}
(...) não é uma realidade objetiva, é algo que os parceiros de fala têm na cabeça. Cada um define, por intermédio de sua fala, o contexto no qual está falando. Os falantes cooperam ou brigam para definir o contexto no qual estão falando.

O discurso não está somente no contexto, mas está sempre construindo esse contexto. O contexto é uma realidade dinâmica. (...) é uma realidade negociada. Não é uma coisa dada. (Maingueneau, 2000, p.30)
\end{abstract}

O contexto, assim, está intimamente relacionado ao discurso dos enunciadores, e este, por sua vez, é o próprio lugar do enunciador na relação com seu co-enunciador.

É fundamentalmente reflexiva: o sujeito que fala está sempre em seu enunciado, tomando certa atitude em relação ao que está dizendo: não tem, na linguagem, uma separação entre a atitude do falante e o conteúdo. Não se pode separar o que se diz da posição do sujeito que fala com respeito a seu enunciado e a seu co-enunciador. (Maingueneau, 2000, p.31)

Discurso, então, é esse modo de enunciar que: (a) não separa o sujeito que fala do que ele fala; (b) constitui-se por sujeitos que ocupam seus lugares na cena enunciativa e, assim, ao mesmo tempo que constroem juntos um contexto, já são parte dele. Discurso, assim, vai de encontro ao que Foucault chama de dispositivo-ato, em Arqueologia do Saber (1997).

Em suas palavras, podemos entender que discurso é prática discursiva, "(por)que supõem, para seu exercício, uma posição, um lugar, que é um lugar na enunciação; isto é, um lugar prenhe de palavras para ouvir e para falar; com os efeitos que isto pode ter sobre a ação de um e outro em relação, num determinado contexto" (Guirado, 2018, p.20).

A AID, ao considerar os lugares exercidos nessa relação como lugares de enunciação no discurso, aponta, assim, para a necessidade de a análise dizer das cenas enunciativas e resgatar, desse modo, a dimensão discursiva das práticas e a concepção pragmática de discurso que dá destaque ao que o ato de dizer mostra, para além do dito, da posição de quem fala, de sua ação em cena (Guirado, 2000).

A análise, por fim, é esse trabalho pragmático que aponta para o que o discurso mostra, pela configuração das cenas enunciativas, das posições dos personagens/interlocutores nelas, de um sentido que se pode construir pela consideração de todo o contexto, e não pelos sentidos das palavras, nem pela posição do significante na estrutura discursiva (Guirado, 2010).

Em seu texto sobre a AID nos atendimentos de crianças com autismo, Guirado (2018) apresenta uma síntese sobre como atender na perspectiva desse método. Citaremos um estrato 
que vem em nosso auxílio, para explicitar ao leitor o que tentamos aqui demonstrar, agora, estabelecendo as relações mais diretas com o contexto clínico dos atendimentos.

\begin{abstract}
Assim, o setting, mais do que poderia pensar um psicoterapeuta, é uma cenografia e, como tal, uma ocasião concreta em que a instituição clínica repõe seus lugares em exercício, faz das falas e dos procedimentos discursos-ato. Compreender dessa forma a relação criança/terapeuta implica operar na suspensão das teorias e dos métodos habituais de tratamento intencionalmente por procedimento e método, por admitir que há uma função enunciativa em jogo a se (re)criar, a partir dos lugres institucionais de criança/paciente e adulto/terapeuta, parcerias particulares, em grande medida, pelo gesto, pela direção do olhar e pela palavra (quando houver). Os brinquedos, os materiais expressivos gráficos ou plásticos bem como aqueles mais imediatamente imaginativos (roupagens de teatro, livros de história) e a presença atenta e interessada do adulto são o contraponto, a provocação constante para que algo aconteça, para que os pequenos se movam no cenário discursivo, indicando a orientação a seguir.

Não deixa de ser um trabalho intenso, o desses atores - nada amadores, no ato de brincar e, com isso, produzir o discurso da sessão a várias vozes e vários corpos, organizando múltiplos sentidos que o contexto permitir reinventar e fazer avançar. (Guirado, 2018, p.138)
\end{abstract}

Aqui estão os princípios da estratégia de pensar/fazer da AID, instrumentando uma clínica da analítica da subjetividade. Aqui estão os princípios que norteiam essa clínica que fazemos com as crianças com diagnóstico de autismo. Aqui estão os princípios que justificam podermos dizer que o que fazemos tem efeito terapêutico.

As crianças que terão suas histórias clínicas comentadas no Capítulo 5 mostram essa clínica que defendemos pelo conjunto desta tese de doutorado.

\title{
4.2 Procedimento
}

Como dito anteriormente, tomaremos como base para a discussão proposta nesta Tese, atendimentos clínicos já realizados pela autora da mesma, e, para que pudessem figurar na qualidade de situações exemplares para um texto acadêmico, eles foram escritos de tal forma a mostrar a articulação de todos os contextos em que as cenas clínicas foram trabalhadas: criança/terapeuta, terapeuta/supervisora. Ou seja, o que se apresentará como texto de tese já é um discurso analítico sobre as cenas discursivas da clínica.

Como apresentamos acima, neste capítulo sobre Método, a visada é essa de uma clínica da analítica da subjetividade, que, no caso de crianças com autismo, logra efeitos terapêuticos, tomando o brincar como o discurso-ato dos parceiros em cena. 


\section{SOBRE AS ANÁLISES}

Como pude demonstrar em minha dissertação de mestrado, em outras formas de tratamento bastante conhecidas, há um problema: o da legitimação do lugar específico de voz/enunciação às crianças nas sessões concretas. Buscarei mostrar, a partir de agora, como se pode agir de um modo diferente quando se pensa com a análise institucional do discurso. É um desafio que me propus enfrontar e que me levou a destacar seis atendimentos, em que em todos, como disse Guirado (2018),

(...) o brincar é o fazer, é o trabalho, é o exercício do lugar de paciente na sessãodiscurso-ato. O prazer que pode ter enquanto brinca é, inegavelmente, a ocasião de exercer seu lugar confortavelmente, explorando no limite suas possibilidades de movimento, comunicação, criação e sua autonomia. Reequilibram-se as relações de poder na prática clínica. As tensões que se criam, se consideradas parte de todo esse trabalho (da criança e do adulto), são produtivas. Prestam-se a desafiar, inclusive, o pensamento e o conhecimento do terapeuta: (a) afinal, o que teria sido motor de tais ou quais mudanças de cenas, de posições de seus protagonistas (das crianças e seus personagens imaginários); (b) como entender certos acontecimentos considerando os procedimentos discursivos em jogo?; (c) como contribuir para o entendimento sobre a instituição do autismo e de seus tratamentos?; (d) como a psicologia do desenvolvimento e outras áreas do conhecimento como a neurologia, a fonoaudiologia e a oftalmologia, por exemplo, por meio de suas intervenções e diagnósticos, podem contribuir? As respostas não estão prontas numa ou noutra teoria ou método. (Guirado, 2018, p.138,139)

\subsection{Cenas em análise}

Agora iremos apresentar ao leitor um breve histórico de algumas das crianças atendidas por nós, bem como algumas cenas exemplares ${ }^{21}$ que ocorreram em terapia, com esse objetivo, o de resgatar os caminhos trilhados por elas como efeitos dos atendimentos, e explicitar, por meio das situações de AID em ato, a ideia básica do brincar como discurso e seu caráter terapêutico, uma vez que pela AID a criança ocupa um lugar de enunciação na cena discursiva do tratamento clínico.

É impotante lembrarmos, aqui, que

(...) quando inicia a terapia, ainda que não consiga expressar-se com clareza, ou pela idade ou por algum tipo de comprometimento, a criança, ao que nos conduzem pensar nossos pressupostos (AID), tem registros de uma história que não cabe, com justeza e transparência, nas previsões ou nos nomes e categorias que se lhes confere o discurso psicológico e/ou psicanalítico. Para além do diagnóstico que porta ou da queixa apresentada por aqueles que procuram o atendimento por ela, partimos do pressuposto de que tenha uma versão, um registro pessoal-afetivo-imaginário, uma memória de

\footnotetext{
${ }^{21}$ As cenas foram escolhidas de modo que pudessem melhor caracterizar o modo como é o trabalho com a AID.
} 
seu vivido real ou fantástico; e que isso a constitui subjetivamente. Ou seja, até o exato momento do seu encontro com o terapeuta, sob o império das relações familiares, construiu um complexo de experiências e, a partir dos lugares que nelas ocupavam, é que se faziam os registros dessas relações, de sua força e intensidade, do seu significado; faziam-se também registros de uma imagem de si e dos outros, de suas valias, de suas competências e limites, de seu lugar no mundo.

Cabe acrescentar que esses registros são cenas, marcas ora mais e ora menos claras e conscientes, ora mais e ora menos aproximadas da realidade vivida, mas sempre fruto do arranjo imaginário possível. (Guirado, 2018, p.140)

\subsubsection{Ricardo}

$\mathrm{O}$ atendimento de Ricardo é diferente dos demais que serão aqui apresentados, por alguns fatores: o primeiro deles é que ele foi atendido por nós, no início (primeiros 8 meses ${ }^{22}$ ), pelo modelo Son-Rise ${ }^{23}$, e o segundo é que na época nós não tínhamos ainda certificação para aplicação da ADOS-2 (e, portanto, ela não foi aplicada).

Por que escolhemos Ricardo, então? Um dos motivos de o colocarmos aqui, como exemplo de análise, é que sua escritura nos permitiu demarcar, pela conduta da terapeuta, o momento em que as discussões e estudos avançaram, fora do contexto específico das sessões. Esse foi um ponto de virada em nossa clínica de crianças com autismo; foi quando apostamos de modo mais definido na AID. Com isso, no que diz respeito ao Ricardo, detivemos nossa atenção às cenas concreta e imaginariamente construídas, por ele e com ele, em brincadeiras e jogos; detivemos nossa atenção aos discursos e seus lugares nessas situações, aos desafios à fala e criação e assim por diante.

Nessa tese, vamos marcar como um período inicial, esse em que o Son Rise era dominante. Até porque, foram as sessões em que ocorriam menos verbalizações e mais gestos e espelhamentos de conduta, conforme supõe o método.

O que notamos, ao acompanhar todo o histórico terapêutico de Ricardo para reconstruílo no presente trabalho, é que, em pouco tempo, parecia lermos sobre um outro garoto na relação com sua terapeuta (esta, diga-se, também diferente: brincando junto, conversando e fazendo propostas, sempre!).

\footnotetext{
${ }^{22}$ Após este tempo, e de muitos questionamentos que nos fizemos ao longo dos atendimentos com o Son-Rise, reconhecemos e admitimos que alguns dos conceitos que o norteavam não faziam mais sentido em nossa prática, por conta, talvez, até da própria origem deste método: uma experiência singular em que os pais da criança com autismo encontraram caminhos de se relacionar com ela. E nós, psicólogas que eramos, tínhamos ali recursos importantes da psicologia do desenvolvimento e da análise institucional do discurso que não estavam sendo contemplados, e que, cada vez mais, se faziam necessários nas sessões.

${ }^{23}$ Son-Rise é um método de tratamento para crianças com autismo de base relacional, emocional e motivacional, criado por Neil Kaufman e Samahria Lyte Kaufman em 1983, em decorrência do diagnóstico de seu filho Raun. A proposta é de um trabalho feito pelos pais e profissionais na casa da criança, em um ambiente preparado para tal. (The Option Institute, 1998-2018)
} 


\subsubsection{Breve histórico}

Ricardo tinha um ano e cinco meses quando sua tia notou que havia algo diferente com ele, relacionado à comunicação. Seus pais contam que inicialmente ficaram bravos com ela, pois para eles Ricardo era perfeito, e não tinha nada. Mesmo assim, um mês depois, levaram o filho a um neuropsiquiatra para avaliá-lo. Ricardo fez exames de imagem (eletroencefalograma e ressonância magnética) que não detectaram nenhuma anormalidade, e recebeu o diagnóstico de Transtorno Global do Desenvolvimento (que viria a ser o TEA, no DSM-V).

Seus pais pediram uma segunda indicação ao pediatra e o levaram a um outro neurologista, que confirmou o diagnóstico do primeiro médico, e, recomendou que ele ingressasse na escola e desse início à terapia de fonoaudiologia voltada para o autismo, uma vez que sua maior dificuldade naquele momento parecia estar relacionada à fala e à interação social.

Naquele momento Ricardo entrou em uma escola regular, que ficava próxima à sua residência e, seis meses depois, começou a terapia de fonoaudiologia (aos dois anos e um mês).

Seus pais continuaram buscando informações sobre tratamento e prognóstico pela internet; foi quando souberam de um workshop sobre o método Son-Rise. Eles fizeram o workshop, e tiveram assessoria da pessoa responsável pelo curso para montar na casa deles um “quarto de brincar ${ }^{24 "}$, local previsto no método em que a terapia deve ocorrer.

Esta pessoa que deu a assessoria para os pais foi quem fez a indicação de que os pais buscassem a equipe que eu faço parte para atender o garoto (um ano após o início da fono). Após três meses de atendimento pelo Son-Rise, ele passou a se consultar com uma nutróloga que prescreveu uma dieta com restrição de glúten, caseína e lactose. Ele seguiu nesta dieta até não apresentar mais alergia a esses componentes no exame de sangue.

Conhecemos Ricardo quando ele tinha exatos 3 anos e 4 meses. Um menino gordinho de cabelos castanhos cacheados e de bochechas rosadas. Tinha um olhar rápido e fugaz, mas acatava com prontidão a solicitação da mãe de dar beijo e abraço ao encontrar com as pessoas. Nós (eu e outras três psicólogas da equipe) estávamos conversando com sua mãe quando ele subiu do parquinho do prédio com a babá. Deu um beijo e um abraço em cada uma de nós e, ao chegar onde eu estava sentada, pegou a caneta que eu estava usando para anotar a conversa com

\footnotetext{
${ }^{24} \mathrm{O}$ "quarto de brincar" é um quarto da casa em que o piso é de um material lavável, há um espelho em uma parede, e estantes fora do alcance da criança com brinquedos que ela goste, de forma a estimulá-la a solicitar o que quer para brincar. A ideia é que seja um ambiente confortável, em que criança e terapeuta, e criança e pais, possam passar um tempo juntos sem se preocuparem se vai sujar algo, se tem algo perigoso para a criança, de forma que a atenção fique integralmente para a criança (Inspirados pelo Autismo, 2016).
} 
sua mãe, e ficou olhando atentamente. Fez alguns riscos no meu caderno, e deu um leve sorriso. A mãe solicitou que a babá o levasse para brincar; com um pouco de resistência dele e insistência da mãe, ele me devolveu a caneta, e foi.

A mãe nos contou que aos dois anos e sete meses ele começou a falar algumas sílabas de algumas palavras, e a ficar bravo quando não era entendido! Também nos contou que, no mês anterior, havia feito a retirada da fralda para o xixi, mas que ainda precisava da fralda para conseguir evacuar.

Ela solicitou que ele tivesse sessões de psicoterapia três vezes na semana, no quarto de brincar, e nos outros dois dias manteria a fono. Poucos meses após este combinado, Ricardo passou a ter sessão cinco vezes na semana no quarto de brincar, e permaneceu com as duas sessões de fono.

Esse ritmo de atendimento estendeu-se por 3 anos e meio (quando Ricardo estava com sete anos, aproximadamente), quando, então, fizemos uma nova proposta de trabalho para o pequeno, já não tão pequeno assim, que foi a de reduzir as sessões para duas por semana, e acrescentar uma sessão com técnicas de teatro que incluisse uma professora de teatro, de modo a dar conta das novas necessidades que passou a apresentar como demanda de trabalho. Aos poucos as sessões regulares, no quarto de brincar, foram se mostrando menos produtivas e necessárias, razão pela qual mantivemos apenas a sessão com técnicas de teatro, por mais 3 anos (até seus dez anos de idade, aproximadamente).

Coincidentemente, neste segundo momento do acompanhamento, a família mudou-se de prédio e Ricardo mudou de escola, tanto por conta da localização, como devido ao fato de a escola anterior ter apenas a educação infantil. Ele continuou (e continua) frequentando uma escola regular e fazendo as sessões de fono, agora com frequência também reduzida.

Após esses outros 3 anos, isto é, após os 6 anos e meio desde o primeiro contato, nosso trabalho com Ricardo chegou ao fim. Não pelo fato de ele não precisar mais, e/ou não ter mais nada a ser trabalhado, mas por uma aposta nossa, em conjunto com os pais, de que era o momento de ele seguir; com as atividades extra-curriculares na escola, com as crianças de sua idade, acompanhando regras comuns e as entendendo, participando de acampamento, enfim...

\subsubsection{Sobre o desenvolvimento de Ricardo durante o atendimento}

Antes de entrarmos nas cenas e análises propriamente ditas, é importante destacarmos o percurso de alguns vetores do desenvolvimento de Ricardo durante o tempo de atendimento. 
Foram longos anos, e ele mudou bastante, principalmente nas áreas costumeiramente associadas ao transtorno do espectro autista: comunicação e linguagem, interação social, brincadeiras e imaginação, interesses restritos e comportamentos repetitivos.

Faremos agora um breve panorama; uma breve descrição, por meio dessas áreas sobre como ele estava e como foi se desenvolvendo. Tais dados foram retirados de relatórios nossos de acompanhamento e de relatórios escolares.

Inicialmente Ricardo fazia contato visual, mas não o sustentava. Comunicava-se apontando, guiando nossa mão para o que ele gostaria que fosse feito, e por sílabas de palavras. Ele aceitava a presença de outras pessoas e permitia o contato físico breve. Interagia por período curto, não tinha jogo simbólico mas conseguia fazer algumas imitações com objetos. Ele ficava muito bravo, chorava e gritava quando algum limite era posto em sua brincadeira e não permitia nenhuma alteração de outra pessoa ao que estava fazendo. Em relação à parte motora, Ricardo demonstrava preferência por atividades em que permanecia sentado e apresentava excelente coordenação motora fina. Quando ficava ansioso ou muito animado, apresentava um movimento repetitivo - dar pequenos pulos em pé, com o tronco inclinado para frente, os braços flexionados e balançando as mãos para cima e para baixo (flapping). Conforme relato da escola, "seu cognitivo" aparentava estar preservado, uma vez que acompanhava sua turma na parte pedagógica de forma exemplar.

Após 3 meses de atendimento, o contato visual começou a se manter, ser sustentado por um pouco mais de tempo. Ricardo começou a tentar falar mais de uma palavra, mesmo que a nossa escuta se guiasse mais pelo som geral semelhante à palavra do que propriamente pela dicção e pronúncia, e passou a responder perguntas simples.

Após 6 meses as palavras começaram a ter mais sílabas, embora elas ainda não fossem muito claras. Conforme o relatório da fono, sua fala espontânea era composta predominantemente por ecolalia imediata. Ricardo começou a usar brinquedos para representar animais e pessoas, como fantoches, e passou a permitir sugestões de variações periféricas em sua brincadeira.

Em um ano de atendimento, Ricardo, com então quatro anos e meio, ainda não falava de forma clara, mas era possível entender o que ele dizia. Sua fala era bastante colada ao que ouvia, fosse o que dizíamos para ele, fosse o que ouvia na televisão, mas, era contextualizada. Ele começou a fazer comentários simples (“que legal!") e a responder perguntas sobre "o que" e "qual o nome". Na maioria das vezes que queria algo começou a fazer contato visual, e 
começou a usar o olhar para dirigir o olhar de outra pessoa (olha para a pessoa, olha para o objeto e volta a olhar para a pessoa).

Em um ano e meio, Ricardo, com cinco anos, já estava falando pequenas frases com verbos, e começou a nos fazer perguntas (“esse é o...?”). Estava interagindo e sustentando a interação e o o olhar por um período de tempo maior; estava aceitando melhor os limites que por vezes colocávamos pedindo ajuda ou dizendo que era difícil de cumpri-los; e estava permitindo parcialmente que o outro o auxiliasse em uma atividade escolhida por ele. Passou a compreender o que era seu e o que era do outro, embora ainda, na fala, invertesse os pronomes. Começou a representar papéis simples em brincadeira imaginativa, e a imitar expressões faciais.

Passado mais um tempo, já aos três anos de atendimento e seis anos de idade, sua fala apresentava apenas algumas dificuldades quanto à pronúncia do /l/ e /r/, sendo a fala, a forma majoritária de comunicação com os outros. Por conta da idade e da crescente interação social que esta supõe, outros pontos de trabalho específicos do convívio social começaram a se fazer presentes, como por exemplo: olhar para o outro enquanto o escuta, olhar para o outro para manter a atenção deste enquanto ele fala, pedir permissão ao mexer em pertences que não eram dele, usar mais elementos ao contar uma situação de forma a contextualizar sua fala e se fazer entender, ajudar o outro sem que isso necessariamente traga um benefício para si, compreender expressões faciais alheias, entender figuras de linguagem e metáforas, dizer sobre sentimentos.

A partir deste momento iniciamos as sessões com a professora de teatro, as técnicas e os jogos de imaginação e socialização. Nela participavam: Ricardo, uma psicóloga da equipe (Fabiana dos Reis Marchiori), a professora (Erica Martinelli), e eu. Essa composição foi estabelecida desta forma para que tivéssemos um número mínimo de pessoas para compor cenas e fazer uma brincadeira de grupo, mesmo que inicialmente o grupo tivesse apenas Ricardo de criança.

Nos primeiros meses, Ricardo apresentava uma dificuldade básica de prontidão para a atividade. Pelo fato de a sessão não ser em seu apartamento, e sim na área externa do prédio, precisávamos que ele descesse quando nós chegávamos. Notamos que, para ele, o sair de casa muitas vezes era difícil, pois requeria certa organização (colocar o tênis, pegar um casaco se estivesse frio, levar uma garrafinha de água). Sem dúvida a babá poderia deixar tudo pronto para ele e inclusive colocar seus sapatos, como chegou a ocorrer, mas nós esperávamos mais dele; esperávamos que como uma criança de sua idade, ele conseguisse colocar sozinho sua meia e seu tênis, conseguisse ir ao armário pegar um agasalho, e pegar a garrafa de água de que tanto gostava. 
Nas atividades de aquecimento, que normalmente envolviam jogos com movimentos dinâmicos, Ricardo muitas vezes ficava sem saber o que e como fazer; como movimentar aquele corpo todo? Na dúvida, esparramava-se no chão!

Logo nas primeiras brincadeiras de imitar e representar cenas simples, nos deparamos com outro ponto importante do desenvolvimento dele: o repertório de histórias e sua dificuldade em recontá-las.

Fomos trabalhando tudo isso aos poucos, sessão por sessão. E outros aspectos importantes para o desenvolvimento dele foram sendo agregados, como a identificação de imagens e em nós mesmas de expressões faciais relacionadas a sentimentos; a construção de narrativas simples; o reconhecimento de pistas corporais que damos ao outro ao conversarmos; sua consciência corporal; formas de expressar suas dificuldades sem precisar se desorganizar e chorar.

Essas sessões seguiram por 3 anos, sendo que no meio do caminho Ricardo fez uma amiga no prédio que participou de alguns encontros nossos, e ainda fez sessões com uma outra menina, também atendida por nós, em nosso consultório.

Ricardo cresceu muito, em todos os aspectos. O trabalho com ele foi intenso, por vezes tenso, e sempre voltado para o que ele já conseguia fazer, e no que poderíamos ajudá-lo a expandir.

Deixo, aqui, o final do penúltimo relatório das sessões com técnicas de teatro:

Foram muitas as mudanças e muitos os avanços pelos quais o $\mathrm{Ri}^{25}$ passou. Tanto em sua vida psíquica, como em relação ao seu corpo, postura, e posicionamento. Sem dúvida, temos hoje um Ri muito diferente, um Ri que consegue manter uma conversa, se interessar genuinamente pelos outros, expressar seus sentimentos e até mesmo criar e fantasiar algumas histórias! Um Ri atento, colaborador, divertido, um moleque! Um garoto que apesar de toda essa grandeza, ainda se vê em muitos momentos como pequenininho, como um bebê, como um serzinho que precisa de muita ajuda para tudo. Que tenta persistentemente nos convencer de que ele não consegue fazer as coisas sozinho, porque ele simplesmente não faz a menor idéia de tudo que já vimos ele conquistar e conseguir fazer.

O Ri cresceu. O Ri está crescendo. Sempre. E se tem algo que todos podem fazer por ele é tratá-lo como um garoto, de quase 9 anos, muito competente e capaz, que é o que ele é. Desde as coisas mais cotidianas e pequenas, como colocar a meia e o tênis, até coisas maiores como criar um personagem e dar vida a ele. O Ri consegue, e ele precisa de que quem está ao redor dele afirme isso para ele e lhe inspire coragem.

E o trabalho continua, e precisa continuar.26

\footnotetext{
${ }^{25}$ Por questões de sigilo, apenas seu nome foi alterado neste registro.

${ }^{26}$ Relatório de acompanhamento da terapia enviado aos pais de Ricardo em dezembro de 2014, escrito por Erica Martinelli, Fabiana dos Reis Marchiori e Luisa Guirado.
} 
Seguiremos, agora, para as cenas analíticas, em que nosso trabalho se mostrará de forma explicita.

\subsubsection{Cenas}

As cenas que serão descritas estão organizadas de acordo com a cronologia temporal do atendimento com Ricardo. Em sua maioria são antecedidas por uma breve contextualização para o leitor, e seguidas por uma explicação.

\section{Cena 1}

Ricardo, como descrito acima, tinha muita dificuldade em fazer cocô fora da fralda, o que fazia com que, muitas vezes, ele segurasse as fezes e ficasse com muita dor na barriga. Ele não sabia pedir para colocar a fralda, dependia da observação dos adultos sobre a contração de seu corpo para que estes colocassem nele a fralda. Entretanto, havia sido decidido pela família que ele não usasse mais a fralda; nem para evacuar! O procedimento era dirigi-lo, então, ao banheiro quando notássemos essa contração. Nós estávamos, ainda, no terceiro mês de atendimento, e Ricardo tinha certo pavor, por assim dizer, em entrar no banheiro e cogitar evacuar ali.

(...) Ele contou os meus dedos das mãos e foi ao teclado (do computador que ficava disponível no quarto de brincar) ver a escrita dos números. Depois disso, ele pegou o cesto, tirou todas as bolinhas, e ao colocar de volta para guardar, começou a dizer os números. Notei que ele começou a se contrair, perguntei se ele queria fazer cocô e ele não respondeu. Como eu achei que ele queria, comecei a empurrar as bolinhas para dentro do banheiro (o quarto de brincar era uma suíte), ora dizendo que elas queriam ir para lá, ora dizendo que elas estavam se escondendo de mim, e pedi sua ajuda para levarmos todas as bolinhas ao banheiro. Quando todas já estavam lá, eu falei para ele que havia chegado a nossa vez de ir, e nós fomos. Ele levantou a tampa da privada e deu descarga, e eu comecei a fazer o gesto de tchau com as mãos para a água. Ele deu a descarga novamente, mas como eu não fiz o gesto, ele moveu minha mão para fazêlo, e eu continuei o movimento. Na terceira vez que ele iria apertar a descarga, eu o impedi colocando a mão na frente do botão, e ele começou a puxar minha mão para que eu tirasse. Eu expliquei para ele que nós dávamos a descarga quando havia xixi ou cocô na água, e que ali não tinha nenhum dos dois... e sugeri que ele fizesse. Ele ficou me olhando por um tempo e depois começou a choramingar. Eu expliquei que não ia adiantar choramingar, e ele começou a gritar. Imitei seus gritos e choramingos, e ele parou imediatamente. Quando eu o olhei, ele estava fazendo cocô na cueca. Fiquei em silêncio, e ele disse "cocô". Esperei mais um pouquinho e tirei sua cueca. Com um papel, joguei o cocô na privada e pedi que ele desse a descarga. Ele deu, e quando quis dar novamente, eu terminei de limpar sua cueca com outro papel e dei para ele jogar e dar a descarga, explicando que seria o último. Ele deu a descarga e nós fomos ao encontro de sua babá para lavá-lo no outro banheiro. Nesse momento ele começou a chorar, e só se acalmou quando a babá falou que eu não iria embora, e eu sentei para esperá-lo no vaso do outro banheiro. (Anotações pessoais, três meses de atendimento, Ricardo com três anos e sete meses) 
Nesta cena fica claro que nos limites entre a imaginação e a realidade (bolinhas que correm para o banheiro e lá se escondem e de outras que não saem de seu corpo para rolar água abaixo, por alguma sorte de impedimento real e imaginário), Ricardo e eu contracenamos, a meio do caminho, uma negociação que pôs alguma coisa em movimento... Talvez, algum sentido bem concreto... Talvez, expectativas e gestos de um em relação ao outro que pudessem se complementar...

\title{
Cena 2
}

Ricardo apresentou por muito tempo certa rigidez ao executar atividades e brincadeiras. Ele imaginava um jeito e fazia várias vezes da mesma forma, ficando muito incomodado quando alguém não entendia ou propunha uma maneira diferente de fazer. Foi um longo percurso para que ele aceitasse pequenas mudanças, até entender que havia mais de uma forma de fazer uma mesma atividade.

$\mathrm{Na}$ cena a seguir, Ri ainda não conseguia usar a fala para explicar o motivo de certas insistências a fazer tudo sempre do mesmo jeito; sequer para me dizer o que o estava irritando tanto. Coube a mim observar, levantar uma hipótese, e dar esse retorno para ele, em palavras.

\begin{abstract}
Após irmos ao banheiro, voltamos para o quarto de brincar e ele quis continuar desenhando. Novamente fez o desenho do círculo dividido em quatro partes com um sinal de soma, e me deu o papel para que eu pintasse os quadrantes. Eu pintei um quadrante da mesma cor que ele havia feito o desenho (contorno) e, enquanto eu pintava ele ficou irritado, colocou as mãos nas orelhas, gritou e virou a folha que eu estava pintando com a face para baixo. Fez, então, o mesmo desenho, e eu repeti a pintura. Novamente ele ficou irritado, e aí me dei conta de que talvez ele não estivesse gostando que as cores dos quadrantes e do contorno se repetissem. Falei para ele essa minha hipótese. Ele fez um novo desenho e apontou para a cor que eu deveria pintar (a mesma do contorno); eu o alertei que ele poderia ficar bravo, caso eu estivesse certa, pois repetiríamos a cor do contorno, e ele, então, escolheu uma outra cor para eu pintar o quadrante. Desta vez, ele não se irritou. (Anotações pessoais, seis meses de atendimento, Ricardo com três anos e dez meses)
\end{abstract}

É importante ressaltar, aqui, a atenção constante e voltada para o que estava sendo feito com ele e para ele, que foi o que possibilitou que eu levantasse uma hipótese para a sua irritação, testasse essa hipótese após ter dito para ele sobre ela, e recebesse a confirmação dela pela nãoirritação dele.

O principal era que estávamos fazendo juntos; o fato de ele querer que eu participasse de sua brincadeira, mesmo que ele não conseguisse me dizer com palavras como era e o que eu deveria fazer. O desenho, a figura, em si, provavelmente fosse indiferente naquele momento.

Nesta cena fica claro que o que foi valorizado foi a vontade dele em me incluir na brincadeira. O como eu iria dar conta dessa tarefa sem irritá-lo e sem que ele quisesse me excluir 
dela, era o que eu teria que construir. Se Ricardo estava me concedendo esse lugar - fosse pelo nosso breve histórico até então, vínculo já constituído, e confiança em mim - eu também estava ali para garantir o lugar dele em cena. Como eu fiz isso? Contando para ele minha hipótese e testando. Eramos, ali, uma dupla, parceiros. Ocupávamos lugares equivalentes no discurso, de igual para igual.

Cabe destacar que esta atenção dada aos parceiros de jogo não exclui, muito pelo contrário, constitui uma experiência emocional de peso (de confiança) para a relação com ele. É o reconhecimento dele na parceria, e isso é afetivo.

Cena 3

Essa nossa parceria, por algum tempo com palavras únicas da parte dele, e poucas palavras da minha, parecia caminhar... Ricardo gostava muito de aprender, e eu aprendi a ensiná-lo.

Hoje eu trouxe para ler com o Ri o livro "Aniversário do Buba", em que em cada página tem um espelho para fazermos o que o Buba propõe: dar um sorriso, fazer cara de surpresa, enfim. Ao final, ele agradece os amigos da história e tem um espelho para agradecer também a criança. Quando o Ri apareceu no espelho, eu disse "É o Ri!", e então ele posicionou livro de modo que eu também aparecia no espelho e disse "O Ri e a Luisa!" (Anotações pessoais, nove meses de atendimento, Ricardo com quatro anos e um mês)

Nesta cena, quem me coloca na situação é o Ri; somos nós dois que estamos ali e, para ele, isso é muito claro.

\section{Cena 4}

Quando Ri começou a se comunicar melhor com a fala, passou também a gritar quando queria algo e não fazíamos imediatamente, ou quando era contrariado, ou quando ficava irritado por conta de uma ação do outro. Fizemos um trabalho intenso para que ele entendesse que não precisava gritar para ser ouvido, bastava falar.

Os aspectos cognitivos de Ri sempre foram muito preservados. Em alguns momentos, inclusive, suspeitamos de hiperlexia. Apesar do atraso na fala, ele tinha um vocabulário extenso e entendia o significado das palavras. Apresentava interesse pela língua inglesa, e gostava de músicas neste idioma.

Eu comecei a cantar uma música dos números em inglês, e ele gritou "não!", e em seguida repetiu bem baixinho para si "não precisa gritar para eu escutar". (Anotações pessoais, um ano de atendimento, Ricardo com quatro anos e quatro meses) 
Esta cena nos mostra que ele estava usando a minha voz, a minha fala para se conter. Mas, na ocasião, foi ele mesmo que ativamente a acionou. É como se ele tivesse já um registro interno da minha fala para se organizar.

Se esta fala era uma "ecolalia tardia", ou uma frase pronta que ele estava repetindo no contexto adequado, não importa. Ali a fala dele que ecoava a minha tinha uma função.

\section{Cena 5}

Teve um momento no processo de terapia de Ricardo em que ele passou a não querer mais brincar só no "quarto de brincar". Queria explorar sua casa; brincar na varanda, na sala de estar e sala de televisão. A impressão que dava era de que queria ter suas possibilidades de interação ampliadas; queria também ocupar outros espaços. Mas, para que pudéssemos trabalhar com ele mais atento e focado, tentávamos sempre voltar para o quarto de brinquedos, na medida do possível.

Fomos pegar o lanchinho dele na cozinha, ele comeu banana e depois quis comer mais, e a babá deu um salgadinho. Quando estavamos indo para o quarto fazer o piquenique (que ele mesmo havia sugerido), ele parou no quarto de tv, entrou e falou que queria comer lá. Eu sugeri comermos na mesa do quarto de brincar, ou mesmo na toalha do piquenique, e ele disse que não, e falou "Luisa no quarto de brincar" e foi me empurrando para fora do quarto de tv. Eu fingi que estava indo e ele fechou a porta do quarto de tv. Então, eu só bati na porta (toc toc toc) e ele veio abrir com o maior sorriso! Eu falei “Oiii Ri!!!” (como costumo falar ao chegar), ele me deu oi e me puxou pela mão para entrar na sala de tv. Comeu o salgadinho, quis mais, pegamos mais, ele comeu tudo e enquanto comia quis ver as fotos dos porta-retratos. Vi com ele um por um, e eu ia fazendo perguntas e ele respondia bastante animado (onde estava, quem era, que roupa era, se estava feliz ou triste, se era bebê ou não). Em uma foto perguntei quem estava de vermelho e quem estava de azul. No começo ele se confundiu, mostrou apenas 1 pessoa, depois que eu mostrei a outra, ele entendeu a brincadeira e respondeu corretamente. (Anotações pessoais, um ano e quatro meses de atendimento, Ricardo com quatro anos e oito meses)

Nesta cena, há dois pontos a serem destacados: o primeiro deles é essa brincadeira que eu inicio ao ir embora quando ele me coloca para fora, por eu estar propondo que ele lanche em um espaço em que ele não quer, e volto batendo na porta, como nos desenhos animados, e nas histórias de lobo mau e porquinhos (e o faço intencionalmente). Eu coloco em cena o jogo, a imaginação. Ele aceita!

Depois, e segundo ponto, é quando Ricardo me leva para ver as fotos, colocando-me em cena e brincadeira, e eu introduzo uma outra parte, uma narrativa (quem era, o que faziam, onde). O que ele faz é muito mais do que uma mera descrição de imagens, é uma narrativa de sua vida, de sua história, pela fotos

Como dissemos nas justificativas introdutórias desse modo de trabalhar clinicamente (capítulos anteriores da tese), e ainda discutiremos no conjunto dos atendimentos aqui 
comentados, narrativas como as da presente sessão são momentos privilegiados das terapias. Muito embora não se possa dizer que sejam somente "narrativas de si" que tenham esse efeito.

Cena 6

Ricardo não gostava muito de se fantasiar e/ou usar chapéus diferentes para brincar. A imaginação era difícil para ele ainda naquele momento, e representar parecia não fazer muito sentido. Mesmo assim, no quarto de brincar havia alguns adereços e uma fantasia de uma apresentação na escola, do ano anterior ao que começamos a atendê-lo.

\begin{abstract}
Após montarmos o quebra-cabeça do mapa do mundo da Disney, Ri pediu "o chapéu". Tirei um por um da estante, e ele não quis colocar nenhum, apenas ficou vendo os que tinha ali. Pediu, então, o chapéu de papai noel. Não havia esse chapéu, então, tirei da estante a última coisa que havia restado, a fantasia de leão! Expliquei para ele que não tinha o chapéu de papai noel, mas que tinha uma fantasia de leão. Expliquei que a fantasia era diferente do chapéu, dava para vestir, e ele quis colocar! $\mathrm{Eu}$ o ajudei a colocar e tirar algumas vezes. Sugeri que andássemos pelo quarto igual ao leão, mas ele não quis, estava mesmo encantado em tirar e pôr, em ser leão e ser Ri. Como a sessão tinha chegado ao fim, sugeri irmos mostrar para a babá ele de leão, e ele quis! Enquanto eu andava no corredor, fui falando "Corre! Estamos na floresta!" e ele veio vindo atrás de mim rindo... e ao ver a babá fez o rugido do leão! (Anotações pessoais, um ano e seis meses de atendimento, Ricardo com quatro anos e dez meses)
\end{abstract}

Essa cena mostra uma construção de brincadeira imaginativa na e pela relação com o outro, em que Ri conseguiu ver um sentido e ela se tornou significativa para ele. Outro, esse, que não um qualquer... Um outro aceita e assume um lugar de enunciação, e que também concede e valida o lugar de enunciação do interlocutor. Um outro que, além disso tudo, já é conhecido e com quem se tem uma relação de confiança.

\title{
Cena 7
}

Ricardo gostava bastante de histórias e de livros, de maneira geral. Em algumas sessões eu levei livros para vermos juntos, normalmente relacionados a algo de seu interesse naquele momento. Aos poucos, com o avanço da fala, ele passou a conseguir nos reportar o que estava pensando e como estava vendo, identificando ou decifrando as imagens.

(...) ele quis ver o livro que eu havia levado, Meu Primeiro Larrousse das Descobertas. É um livro extenso, com várias figuras, e explica muitas coisas: o processo da borboleta, animais ovíparos e mamíferos, os planetas, as estações do ano, o clima, mostra os continentes e tipos de vegetação, alguns comparativos (grande/pequeno), números e palavras. Eu havia levado para vermos juntos uma ou outra parte, pois tem muitas páginas, mas o Ri quis vê-lo inteirinho!

Enquanto víamos o livro, eu fazia perguntas sobre as figuras, sobre o que tinha sido explicado, e ele respondia com alegria! Ele pedia para eu ler, e algumas vezes eu disse "vamos ver essa parte?" e ele repetiu. Um momento muito bacana foi quando chegamos na parte das palavras e tinham várias fotinhos de pessoas e coisas, e então ele começou a contar as fotos " $1,2,3,4$ ”, então eu falei "Ei, Ri! A parte dos números já foi! Agora estamos nas das palavras!" e ele automaticamente começou a apontar as 
figuras e falar "a,b,c,d"! Muito inteligente esse menino! Ao final do livro, ele disse "Que livro legal!!!". (Anotações pessoais, um ano e oito meses de atendimento, Ricardo com cinco anos)

Nesta cena temos o registro de uma criança que na relação com a terapeuta assume um lugar próprio de enunciação, entendendo e aceitando o comentário de sua parceira, e respondendo à ela de forma espontânea, mostrando o quão dentro estava na brincadeira e validando o raciocínio do comentário dela ao refazer o seu.

\section{Cena 8}

Aqui, na cena que se segue, temos um exemplo de uma pequena flexibilidade de $\mathrm{Ri}$ quanto a um jogo. Em muitas sessões ele pedia para ficar com o que eu havia levado até a próxima semana. No caso desta cena foi o jogo Treme Blocos, em que cada pessoa tem um tempo para colocar sua peça (há alguns tipos de peças e cada tipo é de uma cor) de modo a formar uma torre e, caso não consiga colocar naquele tempo, a base do jogo treme desmontando a torre. Ele ficou com o meu jogo, e entre uma sessão e outra, uma peça foi perdida.

Ricardo tinha verdadeiras crises quando perdia qualquer peça de qualquer jogo; ele ficava extremamente bravo e frustrado, e nós acabávamos, na maioria das vezes, encerrando a partida dado o estado em que ele ficava.

As modificações nas brincadeiras, fosse por perda de peça ou por alteração proposital de alguém, o desestabilizavam. Aos poucos, ele foi conseguindo entender que às vezes algo se perde, mas a gente consegue procurar e encontrar depois. Foi um pouco mais difícil entender que as pessoas são diferentes e têm jogadas e formas de jogar diferentes...

\footnotetext{
Brincamos algumas vezes com o Treme Blocos, e ele me contou que perdeu uma das peças da cor laranja. De fato, a peça não estava lá, e falei que nós a procuraríamos depois. Ele aceitou brincar sem. Certo momento ele quis trocar uma peça do lugar que eu havia colocado, e eu disse para que não, pois tinha sido a minha vez e eu queria a peça ali. Ele insistiu dizendo que ele sabia o lugar certo e não era onde eu tinha posto, e eu insisti dizendo que o lugar certo era o que eu tinha escolhido, pelo simples fato de estar na minha vez. Ele começou a falar que não, e fez aquela cara de "eu vou chorar se você continuar insistindo", e então eu falei para ele que tudo bem, que ele poderia colocar a minha peça onde ele queria, mas que nós dois sabíamos que não era porque havia um lugar certo para colocar. Ele ficou me olhando em silêncio por um tempo, trocou a peça de lugar, e continuamos brincando normalmente por mais um tempo. (Anotações pessoais, um ano e dez meses de atendimento, Ricardo com cinco anos e dois meses)
}

Nesta cena eu o elejo como um interlocutor que entende meus argumentos, e ele age como tal. Há um ar de parceria que não importa muito o que é dito ou feito, mas essa seriedade em que um considera o outro um parceiro de peso. 


\title{
Cena 9
}

Uma das maiores qualidades de Ricardo era a vontade de aprender e o fato de aceitar os desafios que eu colocava para ele a cada sessão.

\begin{abstract}
A sessão de hoje com o Ri foi muito interessante! Eu levei um jogo para ele em que a gente tinha que pegar umas cartas com figuras e o nome da figura, e dar dicas para a outra pessoa adivinhar o que é. Foi muito legal ver a evolução das descrições que ele fazia para me dizer o que era! Primeiro via a figura e me contava o que era, depois, eu falei para ele começar dizendo "É uma coisa/animal/roupa/sapato/objeto..." e contar o que ele via na figura, como cores e formas. Ele pegou a figura de uma laranja e disse "é uma fruta... eu gosto mais do suco de laranja do que da fruta", risos. Depois entendeu que não podia entrar o nome da figura, e me deu dicas ótimas como: ao ver uma régua ele disse "é uma coisa que mede as coisas, mede parede, chão"; ao ver um vestido, disse "é uma coisa que se veste em casamento". Eu pedi mais dicas, perguntei se era roupa ou sapato e ele respondeu que era roupa. Perguntei se era uma roupa que homem e mulher poderiam vestir, ou só mulher, ou só homem, e ele respondeu que só mulher!

Ao ver um óculos ele disse que era uma coisa que a gente usava quando estava sol. Eu perguntei se era na cabeça ou no rosto e ele disse no rosto!

Enfim, foram muitas figuras! No começo percebi que era difícil para ele descrever, e que às vezes não sabia como fazer, mas logo entendeu e foi muito bacana vê-lo tentando se expressar! (Anotações pessoais, dois anos e dois meses de atendimento, Ricardo com cinco anos e quatro meses)
\end{abstract}

Esse registro nos ajuda a ver como que a partir do momento em que eu o qualifico como interlocutor (isto é, considero que ele pode sim jogar o jogo e desenvolver um modo mais elaborado de participar, e dou modelos para que ele consiga se orientar e formular as próprias falas) ele assume com muita propriedade e naturalidade, conforme vai entendendo o jogo. E tudo isso é feito assim, como uma brincadeira.

\section{Cena 10}

Segue agora um pequeno relato feito sobre uma abertura para o terreno da imaginação que Ri nos concedeu, ao escolher para brincar o circo, e que eu pude ampliar para uma narrativa, criando cenas divertidas, que permitiram que ele entrasse um pouco nesse universo da fantasia.

Ele escolheu o Playmobil do Circo para brincarmos. Montamos e então eu comecei a fazer uma narrativa sobre o que ia acontecer, como o domador falando com o respeitável público, dizendo qual animal ia fazer qual acrobacia, enfim. Ele adorou! Brincamos 3 vezes seguidas desse modo, e eu ia fazendo variações na fala, no conteúdo, e ele ficava me olhando, prestando atenção e dando risada. Ao final da terceira vez, ele colocou o leão indo embora passando por cima das grades, e então eu fiz o domador falando "Volta pro circo, leão!", e ele se divertiu, começou a correr com o leão pelo quarto para eu pegá-lo, e quando eu o pegava fazia cócegas e ele trocava o personagem que fugia do circo. (Anotações pessoais, dois anos e dois meses de atendimento, Ricardo com cinco anos e quatro meses) 
Nesta situação alguns pontos merecem destaque. O primeiro deles é o como a minha narrativa sobre a cena que ambos estavam vendo, o circo montado, e a brincadeira imaginativa que eu estabeleço com aqueles objetos, captam a atenção de Ricardo. O segundo é o como, ao longo das três narrativas que fiz, ele encontra um modo de fazer parte da brincadeira como agente, não só como espectador. O terceiro é o como essa forma de ele entrar na brincadeira coloca-o em cena também, continuando uma narrativa que eu havia iniciado, fazendo, agora, parte dela. E o quarto é sobre o como conseguimos, nós dois, representar a cena com objetos (boneco do domador e boneco dos animais) e, naturalmente, fazer a passagem para a representação de papéis ( $\mathrm{Ri}$ era o animal que fugia do circo, e ele saia correndo pelo quarto, e eu era a domadora que corria atrás dele pelo quarto e fazia cócegas nele, não no boneco do animal).

É uma cena com muitas passagens, e passagens importantes, que nos dizem de um desenvolvimento da brincadeira entre parceiros com lugares de interlocução assegurados na e pela relação já consitituída.

\section{Cena 11}

As próximas duas cenas ocorreram na mesma sessão e serão apresentadas juntas, como apareceram no registro.

(...) falei para ele que havia levado, também, dois jogos, o Jogo do Rabisco e o do Fazedor de Histórias. Ele quis começar pelo do rabisco, e então eu expliquei para ele como era: eu ia fazer um rabisco e ele teria que transformar aquele rabisco em uma figura, e depois ele iria fazer um rabisco para mim e eu teria que transformar em uma figura. Ele ficou super animado e começamos a brincar. Embora eu tenha falado para ele que ele poderia fazer um rabisco para mim diferente do que eu havia feito para ele, ele fez todos iguais. Foi muito bacana vê-lo curioso para saber o que eu iria desenhar, e também muito criativo quanto ao que ele iria desenhar. Um dos desenhos que mais me chamou a atenção foi que eu fiz essa forma ^ , e então ele fechou o triângulo, fez um risco no meio e disse que era um diamante!

Quando fomos brincar com o Fazedor de Histórias, Ri ainda estava com a dinâmica do Jogo do Rabisco na cabeça, e quis escrever e desenhar o que eu desenhava e escrevia. Isso se manteve quase até o fim, quando ele aceitou que a nossa história seria a mesma, ficaria junta! Eu contei para ele que para uma história ser feita, nós precisamos de alguns elementos, o primeiro são os personagens (pedi para ele desenhar um, ele desenhou uma abelha, e eu desenhei um girassol), depois vem o lugar em que a história irá acontecer (a nossa seria em um jardim), as ações dos personagens (eu fiz a abelha indo pegar o pólen do girassol, e ele fez as maçãs caindo da macieira que eu havia desenhado no jardim), e por fim o enredo, que é a história completa, com todas as partes. Depois dos desenhos, começamos a escrever o enredo, e foi muito interessante ver o Gui criando uma história, me dizendo as características dos personagens quando eu perguntava, enfim. Foi uma sessão muito surpreendente! (Anotações pessoais, dois anos e seis meses de atendimento, Ricardo com cinco anos e oito meses) 
É interessante notar que Ricardo persistiu no jogo do Fazedor de Histórias no mesmo modo em que brincou com Jogo do Rabisco, mas depois aceitou a proposta de mudança, entendeu, e interagiu de acordo: ora ele era ele, ora ele era eu, ora ele deixava seu personagem nas minhas mãos, ora pegava-o de volta.

E na história que criamos juntos, o sentido que tem ele ter feito uma abelha e eu um girassol, é difícil de dizer, pois estávamos ali criando juntos; o mais importante era ele aceitar e entrar na tarefa como co-laborador.

Com o Fazedor de Histórias consegui mostrar para ele o processo de criação de uma narrativa, que era o que ele tinha dificuldade de entender e criar por si só. É como se nessa sessão, com esse jogo, tivesse conseguido lhe oferecer ferramentas para que pudesse fazer escolher e fazer diferente.

Acima de tudo exercemos uma flexibilidade na mudança de assentos com a criação dessas cenas. Os efeitos disso, na esfera afetiva, difíceis de se apreciar neste momento, talvez possamos verificar em conversas difíceis que tive que ter com ele, no decorrer de todo o atendimento. Sobretudo aquelas que diziam respeito ao seu modo de abordar as pessoas e se apresentar no grupo de iguais. Mais adiante, quando ele convida uma menina do prédio para brincar, ela "foge" dele. Quando lhe falei que o comportamento dela talvez tivesse a ver com o modo como ele se apresentou, iniciamos um diálogo envolveu esses fatores afetivos e de autoimagem, complexos, delicados, de dizer. Lá, a tarefa afetiva se beneficiou desta outra, de se ver em retrospectiva em seus gestos, de se colocar no lugar da menina e se ver com os olhos dela, e depois, ainda, apostar em mim que seria possível fazer diferente (vide cena 5.1.3.13).

\section{Cena 12}

O leitor entrará em contato agora com o registro da sessão que nos impulsionou a pensar nas sessões com técnicas de teatro, tendo em vista as dificuldades ali apresentadas por Ricardo. Neste relato há a descrição de cenas importantes que dizem do desenvolvimento de Ri até então. Ele caminhou bastante? Sem dúvida! Ainda há mais chão para caminhar? Sempre!

\footnotetext{
A sessão de hoje foi muito interessante. Eu levei para brincar com o Ri um jogo de cubos para inventar histórias, e um giz que desenha em espelhos e vidros. Quando cheguei ele logo quis ver o que eu havia trazido, e como estava um dia bonito eu sugeri de brincarmos lá embaixo e ele aceitou, falou até para levarmos uma bola de futebol! Quando chegamos lá embaixo, ele disse que queria primeiro brincar com o jogo dos cubos, e então eu sugeri de brincarmos no jardim, mas ele não quis, disse que queria ir na brinquedoteca. Fomos pegar a chave, mas a chave não estava na portaria, depois voltou, aí fomos de novo pegar. Durante esse tempo, ficamos conversando e foi muito bacana! Ri respondeu minhas perguntas e comentou coisas comigo espontaneamente (falou sobre o aniversário dele, a festa, e eu fiz perguntas sobre a escola e se ele tinha matado a saudade dos pais), ele estava querendo conversar, interessado.
} 
Já no elevador, ao descermos, ele conversou com uma faxineira que estava limpando. Ele perguntou para qual andar ela ia, se ela limpava sempre o elevador, se ela estava todo os dias no prédio. Muito legal. A faxineira respondeu tudo, foi um barato!

Entramos na brinquedoteca e começamos a jogar o jogo dos cubos. São 9 cubos e em cada face há figuras. A brincadeira é rolar os 9 cubos e inventar uma história com as imagens que aparecem. Ri entendeu com muita facilidade o que era para ser feito, e após eu dar um exemplo ele logo quis inventar sua própria história e foi o máximo!!! Ele contava encadeando as imagens, fazendo sentido, e quando eu perguntava algo (o nome do personagem, porque ele tinha feito aquilo) ele respondia com prontidão. Ele gostou bastante! Eu inventei mais uma história, e quando ele ia inventar outra chegaram 3 babás com 3 meninas pequenas, de 1 e 2 anos.

Quando Ricardo as viu, ele ficou tímido, se aproximou de mim e começou a contar a história dele bem baixinho. Quando terminou, eu perguntei se ele queria continuar brincando, pois parecia ter ficado tímido com as pessoas que chegaram. Ele disse que não queria, e eu propus de brincarmos de outra coisa ali mesmo. Nisso, chegaram uns meninos que deviam ter por volta de 7 anos, e chegaram fazendo barulho, pulando nos carrinhos, e tal. Ri ficou olhando, parado, e só quis brincar quando eles saíram da brinquedoteca (eles ficaram bem pouco tempo, acho que só foram lá para olhar).

Ele mexeu nos carrinhos que os meninos tinham subido em cima (aqueles que são tipo motoca), e aí eu sugeri de levarmos no posto para colocar gasolina (tinha um posto de brinquedo lá). Ele gostou da idéia, calibramos pneu, colocamos gasolina, falei quanto era, se era caro ou barato, pedi para ele pagar, e ele adorou. Brincamos disso umas 4 vezes, com todos os carros que estavam lá.

Depois disso, Ri ficou olhando para fora e eu perguntei se ele queria jogar bola, e ele disse que não. Perguntei se queria ir ao banheiro pois vi que tinha um pouco de xixi em sua calça e ele disse que não. Fui com ele mesmo assim ver onde era o banheiro, e então ele parou na porta do elevador e disse que queria subir. Falei para ele que precisávamos pegar as coisas na brinquedoteca e devolver a chave antes de subir, e pedi para ele me ajudar. Ele foi comigo, e enquanto pegávamos as coisas as babás foram embora. Eu perguntei para ele, então, se agora que não tinha mais ninguém lá, se ele queria ficar mais ou se queria subir, e ele disse que queria ficar mais.

Nós desenhamos na lousa, fizemos uma praia com o papai surfando, e depois brincamos de andar de cavalo pela areia (sentamos no cavalinho que tem lá e imaginamos todo o resto).

Como estava sol, sugeri brincarmos no parquinho, e com um pouco de receio Ricardo aceitou. Fomos no gira-gira e depois propus de irmos na balança. Ri logo falou "Não dá, tem criança lá", mas não tinha nenhuma. Pedi para ele olhar, pois eu não estava vendo nenhuma, ele olhou e disse que então tudo bem. Na balança, eu supus que Ri sabia balançar, mas ele pediu para que eu o empurrasse, e depois de tentar ensiná-lo a balançar sozinho eu o empurrei e então ele falou "por que vc está empurrando tão alto? Eu quero parar." Eu parei para ele, e nós fomos no brinquedão. Ele disse que queria subir pela escada para passar na ponte, e nós fomos. Na casinha, ele falou todas as formas que tínhamos para descer, e quando eu disse que ia descer pelo cano ele ficou olhando com cara de susto. Eu perguntei se ele sabia descer por ali e ele disse que não. Eu o ensinei como fazer, disse que tínhamos que sentar e tal, e desci. Ele desceu pelo escorregador. Na segunda vez, ele foi para perto do cano, falei que poderia ajudá-lo, ele segurou e então ficou com uma cara de medo, e aí eu falei "Ri, vc ta com medo de descer por aí? Se vc tiver, não tem problema, você pode descer por outro lugar." E ele "Eu to com medo, eu vou descer pelo escorregador", e foi.

Ele viu a casinha de madeira e perguntou quem morava lá. Eu disse que lá poderia morar quem a gente imaginasse, quem a gente quisesse, pois era de brincadeira. Ele quis ir até lá e perguntou se poderia entrar. Eu falei que se tivesse alguma criança dentro da casinha, a gente tinha que perguntar pra ela se poderíamos entrar, mas que se não tivesse ninguém, nós poderíamos entrar direto. Quando chegamos, não havia ninguém e ele perguntou pra mim se poderia entrar. Eu disse que sim, e ele entrou, e depois eu entrei. Ele novamente perguntou quem morava lá, e eu dei a mesma resposta, e completei dizendo que nós podíamos brincar que ele morava lá, mas ele logo me respondeu que não, pois ele mora no andar 15 !

Depois disso, subimos pois já estava no horário de encerrar a sessão. Essa sessão foi muito interessante por vários motivos. Primeiro porque Ri conversou bastante, fez e 
respondeu perguntas, estava atento e interessado. Depois porque eu nunca o tinha visto no meio de outras crianças, e me chamou muito a atenção o receio que ele tem de ficar com outras crianças no mesmo espaço, e mais ainda de tentar qualquer aproximação. Vejo que precisamos trabalhar bastante isso; ir mais vezes ao parquinho, promover encontros com outras crianças, convidar amigos para participar da sessão, enfim. Também achei muito curioso o Ri não saber se balançar, ter achado que estava muito alto, e ter tanto receio de descer pelo cano no parquinho (ele era quase do tamanho do cano, seria até sem graça descer por ali, sabe?). Precisamos trabalhar mais essa parte corporal/física, pensei que talvez fosse muito importante fazermos atividades com ele na quadra de correr ou jogar algo. (Anotações pessoais, três anos de atendimento, Ricardo com seis anos e seis meses)

A cena do jogo com os dados de inventar histórias mostra a competência e o prazer de Ricardo em inventar histórias. E isto, agora, já como definitivo; a partir do momento em que apresentei as ferramentas, ele passou a dominá-las e ter prazer em usá-las. Mas, como era de suspeitar, esse saber e prazer ele só conseguia viver em uma relação de confiança comigo e com adultos em posição equivalente à minha.

Na cena seguinte, de outras pessoas e, sobretudo, dos meninos de sua idade, entrando na brinquedoteca, a situação foi de medo e paralização, sinalizando que a interlocução comigo não era possível de se manter porque havia outros reais em cena (as outras crianças: as pequenas, acompanhadas de suas babás, e os meninos como ele, acompanhados de sua ação sobre o objetos com força).

Já na cena da balança e no cano do brinquedão foi possível ver todos os outros medos que ele tinha em relação a usar o próprio corpo como instrumento de brincadeira, e dele com os objetos em ambiente aberto. Minha atuação foi a de respeitar e conversar com ele sobre o medo; e como, nas atividades e nos ambientes protegidos, dar a minha ação como modelo. Mas, na medida em que ele não conseguiu seguir, propus uma saída mais viável, que era que ele fizesse o que se sentisse mais confortável (escorregador).

Como o relato da sessão mostra, naquele momento pensei o quão fundamental era estender as situações e condições de aprendizado para ele, de tal maneira a incluir personagens da vida real como parceiros, e não como sinalizadores de perigo.

Foi aí que as sessões com técnicas de teatro, uma professora de teatro e uma outra psicóloga tiveram seu início.

\section{Cena 13}

Nós começamos fazendo as "sessões de teatro" em uma área externa do prédio de Ricardo. Por ser um condomínio de prédios, havia um andar com uma extensa área verde, com bancos e alguns espaços semiabertos, apenas cobertos com madeira. A princípio elegemos um desses locais semiabertos para darmos início as sessões, primeiro por conta do calor que fazia 
na época, e depois porque de certa forma ficaríamos visíveis e poderíamos ver também outras crianças e, quem sabe, incluí-las em nosso grupo.

Segue o relato de uma cena que ocorreu nesse espaço:

\begin{abstract}
Nós estávamos fazendo uma brincadeira inicial, de aquecimento, quando percebemos que uma menina da idade do Ri estava nos observando à distância. Ele a viu e comentou que ela estava nos vendo. Eu perguntei se ele estava incomodado, e ele disse que não, que queria que ela brincasse também. Sugeri que ele fosse até ela perguntar se ela gostaria de brincar com a gente. Ele fez uma expressão de timidez, e disse para eu ir. Eu o incentivei a ir, dizendo que seria bacana ele falar com ela, e que talvez ela quisesse brincar com ele, que também era criança. Ele insistiu para eu ir, e então eu propus de ir junto com ele, mas que ele falasse com ela. Ele aceitou, e no curto caminho até a menina, eu disse para ele perguntar se ela queria brincar com a gente. Então, Ri chegou bem perto da menina, aproximou bastante seu rosto ao rosto dela, abriu bem os olhos, iniciou seu movimento de inclinar o tronco para frente, dar pulinhos, dobrar os braços e balançar as mãos, e falou "Você quer brincar com a gente?". A menina pareceu assustar-se e se afastou. Ele insistiu do mesmo modo, e ela saiu correndo dizendo que não. Ri foi correndo atrás dela. Eu pedi que ele parasse de correr, e caminhei até ele. A menina entrou na sua torre e pegou o elevador.

Ri não entendeu porque a menina havia saído correndo. Ele me perguntou porque ela não quis brincar, e eu respondi para ele que talvez ela tenha ficado um pouco assustada, e preferiu ir para um lugar seguro, a casa dela. Ele perguntou porque ela tinha ficado assustada, e eu expliquei para ele que tinha sido muito bacana ele perguntar se ela queria brincar, mas que talvez ela tivesse se assustado com o jeito como ele perguntou. Ele perguntou "como?", e eu perguntei se ele percebeu que logo que ele perguntou pela primeira vez, ela se afastou dele. Ele respondeu que sim, e aí eu disse que ela se afastou porque ele chegou muito perto do rosto dela para falar com ela, e que talvez ela tivesse estranhado ele dar os pulinhos, porque as outras pessoas não costumam conversar com ela assim. Ele falou "é". Eu falei pra ele que tudo bem, que nós íamos conversar melhor e pensar juntos em outro jeito, de ele se aproximar das pessoas. Ele respondeu "é", e nós voltamos para o espaço do teatro, e ele pediu para continuar a brincadeira.

Eu fiquei muito apreensiva pelo contato com outra criança ter se dado desta forma, mas Ricardo pareceu entender minhas explicações. Precisamos, agora, trabalhar esses "ajustes sociais"; o olhar mais espontâneo, uma distância mais adequada do outro e sem pulinhos, se possível... (Anotações pessoais, três anos e nove meses de atendimento, Ricardo com seis anos e nove meses)
\end{abstract}

Nesta cena, fica clara a dificuldade de Ricardo em perceber o outro e as regras sociais, mas também fica claro seu receio de ir para essa interação. $O$ álibi dele é a confiança da relação estabelecida comigo como possibilidade de se arriscar.

\title{
Cena 14
}

Algumas semanas após a primeira tentativa de aproximação de uma criança do prédio, estávamos no mesmo local do prédio, em outra brincadeira de aquecimento, quando uma outra menina, da idade de Ricardo, e seu irmão de 3 anos, se aproximaram de nós, e ficaram nos observando.

Perguntei pro Ri se ele queria chamar a menina para brincar com a gente. Ele disse que sim. Eu disse que iria com ele, como fizemos da outra vez, mas que dessa vez 
faríamos diferente duas coisas: a primeira é que ele ia dizer "Oi", dizer seu nome e perguntar o nome da menina, e depois perguntar se ela queria brincar junto. A segunda é que ele iria tentar não se aproximar tanto do rosto dela, respeitando o espaço entre as pessoas (que trabalhamos com os desenhos e encenações das bolhas e "kinesfera"). Ele topou na hora e fomos! Foi surpreendente! Ele seguiu todo o combinado, e a menina não só não se assutou como aceitou a proposta! Ela teve dificuldade de entender o nome dele, por conta da pronúncia do /r/, mas eu o ajudei um pouco, e ela nos contou o nome dela, Alice.

Ri perguntou, espontaneamente, em seguida, em qual torre ela morava e em qual andar. Falou em qual torre e andar ele morava, e disse "Ah, não! Você mora em um andar mais alto que o meu!".

Explicamos o jogo para a Alice, pedindo para o Ri dar as coordenadas, e ele aceitou. Explicou com um pouco de dificuldade, mas estava visivelmente feliz. Alice notou sua dificuldade, e em alguns momentos disse "não entendi, o que o Ri falou?" e "Ah, então é pra correr até ali?". Não respondemos por ele em nenhum momento. Pedimos que ela perguntasse para ele, e ele explicou novamente. Ela brincou quase a sessão inteira com a gente, e só parou quando o avô chegou com o irmão dizendo que eles precisavam subir para almoçar e ir para a escola. Ela disse que tinha gostado muito de brincar com a gente, e o Ri perguntou se ela viria na próxima "aula", e ela disse que sim! (Anotações pessoais, quatro anos de atendimento, Ricardo com sete anos)

Alice voltou, mesmo, em outras sessões. Em algumas, trouxe também o seu irmão, e foi muito interessante ver que o Ricardo ficava irritado por não entender o que o irmão dela falava, ou quando ele demorava para entender ou participar de um jogo, exatamente como ele, Ri, fazia.

Em outros momentos, também, pudemos observar a diferença de processamento de informação e ação de Ricardo e Alice, o que nos ajudou a aprimorar ainda mais nosso trabalho com ele, uma vez que podíamos observar in loco tanto as dificuldade de Ri na interação com crianças, como na dificuldade das outras crianças em relação ao Ri.

Os pulinhos, ele continuou dando, e por vezes tivemos que explicar que ele fazia isso quando estava muito feliz. Mas, de resto, Ricardo abraçou a oportunidade de ter uma criança de sua idade para brincar, e conseguiu entender e organizar seu corpo frente ao outro.

\section{Cena 15}

Em algumas sessões de teatro notávamos Ricardo bastante ansioso: ele não conseguia focar e prestar atenção e movimentava-se bastante. Mas também percebíamos, ora pelo que nos contava sobre a semana, ora pelos comentários que fazia, que outros sentimentos habitavam seus pensamentos e sensações, como a saudade, o medo e a raiva, e que pouco sabia nos dizer sobre eles.

Começamos, então, a composição de um "Livro dos Sentimentos", em que

(...) nós escolhíamos qual seria o sentimento em uma sessão e, para a próxima, cada um deveria levar um objeto e uma situação sobre aquele sentimento. Também valia levar livros que tivessem a ver com o sentimento que estávamos estudando no momento, com alguma história ou imagem relacionada ao assunto. Tirávamos fotos para ver e mostrar como as pessoas ficavam quando estavam sentindo determinado 
sentimento; que cara elas faziam, como era. Tudo para ajudar o Ri a reconhecer as expressões faciais e corporais nele e nas outras pessoas, e auxiliá-lo a se relacionar com os outros para além do que é dito expressamente com palavras.

Deu certo. Fizemos, inclusive, história sobre alguns sentimentos! Escrevemos e descrevemos com bastante detalhes, imagens e textos, os principais para o Ri, os que ele escolheu como sendo os que ele mais sentia (sim claro, com ajuda nossa em relação à identificação desses sentimentos).

Um sentimento que teve bastante destaque foi a ansiedade. O Ri descobriu o que era ansiedade e que ele sentia isso em um dia em que estava bastante agitado, com muita dificuldade de se concentrar nas atividades, e nos disse que estava "tonto". Primeiramente, tentamos eliminar qualquer possibilidade de isso ser uma sensação física do tipo tontura. Depois, fazendo perguntas e conversando com ele sobre isso, concluímos que o nome dessa "tontura" dele era "ansiedade".

Com o tempo, fomos vendo, com ele, que esse sentimento é bastante recorrente em sua vida. Fizemos, então, alguns jogos e brincadeiras para ajudá-lo a se acalmar, tranquilizar, e até mesmo para ele conseguir identificar quando está sentindo isso e o que pode fazer para se sentir melhor (p.e.: respirar com o líquido mágico, exercícios de ioga, entre outros).

Desenhamos máscaras de sentimentos, e os identificamos em diversas histórias. Brincamos também de identificar em imagens os sentimentos e até mesmo com mímica entre nós. (Anotações pessoais, quatro anos de atendimento, Ricardo com sete anos e seis meses)

Notem que foi devido a esse acompanhamento e reconhecimento minucioso das necessidades e dificuldades de Ricardo que conseguimos fazer propostas para ele que lhe fizessem sentido e, assim pudessem provocar modificações no seu modo de expressar-se e interagir com os outros. E esse acompanhamento e reconhecimento de suas necessidades só foi possível porque lá trás, quando ele ainda era pequeno e mal falava, estabelecemos com ele uma relação em que nós e ele tínhamos lugares enunciativos garantidos, e ocupávamos com propriedade, ora concedendo, e ora ocupando o que nos foi concedido.

Assim, o que fez com que o atendimento fosse terapêutico foi a criança e a terapeuta terem lugares de interlocução garantidos, e a terapeuta ser uma interlocutora qualificada, no sentido de acompanhar essa criança em seus gestos, movimentos, falas, necessidades e dificuldades. E tudo isto, estamos sempre supondo, se faz em um vínculo de confiança recíproca, numa experiência afetiva singular.

No fundo, é um trabalho de dedicação e tão intenso que tem esses efeitos. E é difícil matizar definitivamente, pois corre-se o risco de perder o fio e não conseguir manter todos os pratos em tensão e movimento.

Este foi o atendimento mais intenso, extenso e com mais registros de nossa parte. Seguiremos, agora, para outro, tentando manter a riqueza de dados e detalhes para que o leitor continue nos acompanhando nesta empreitada! 


\subsubsection{Gustavo: a construção do dizer de si}

Quando iniciamos (eu e Fabiana, também psicóloga na Equipe Novo Olhar ${ }^{27}$ ) o trabalho com Gustavo estávamos em uma fase de transição do Son-Rise para a AID. Tínhamos certo reconhecimento no nosso meio pelo trabalho desenvolvido com o Son-Rise, e ainda eramos procurados para trabalhar com o método. A avó de Gustavo foi quem passou nosso contato aos pais dele, por conta de conhecer uma criança atendida por nós pelo Son-Rise.

No momento em que demos início ao atendimento ainda não tínhamos a certificação para a aplicação da ADOS-2, mas, durante o processo terapêutico dele, a escala foi aplicada com o sentido de reavaliar os sinais e sintomas de autismo após um período de dois anos e meio de trabalho. Mostraremos a seguir um breve histórico de Gustavo, seu desenvolvimento durante o tratamento, e as cenas que exemplificam e ilustram nossa abordagem.

\subsubsection{Breve histórico}

Gustavo nasceu com um hemangioma cavernoso logo acima do olho esquerdo, próximo à sombrancelha. Devido ao risco de progredir e prejudicar sua visão, ainda quando bebê, ele fez diversos tratamentos antes do primeiro ano de vida com o objetivo de bloquear a mancha e reduzí-la. Um dos tratamentos, conforme o relato dos pais, foi com laser e, para que fosse possível a aplicação, ele ainda bebê ficava deitado com a mãe segurando sua cabeça, enquanto suas pernas e seus braços ficavam presos, para que ele não se mexesse e não se machucasse com o próprio laser.

Ele entrou na escola com um ano, e aos quase dois anos de idade a escola notou a dificuldade dele em relação à fala e fez a indicação de uma psicóloga, psicanalista de orientação lacaniana. Os pais decidiram, então, levar Gustavo a um neurologista infantil, o primeiro no qual foi diagnosticado com atraso de linguagem.

Por indicação de uma das avós do menino, ele iniciou terapia fonoaudiológica voltada para a reorganização neurofuncional, pelo Método Padovan, e também iniciou a psicoterapia com a profissional indicada pela escola.

Aos três anos e quatro meses, também por indicação de uma das avós de Gustavo, seus pais entraram em contato comigo. A demanda da família era por atendimento domiciliar, duas

\footnotetext{
27 A Equipe Novo Olhar foi fundada por mim e por Fabiana dos Reis Marchiori em 2009. É composta por psicólogos que atuam com a AID e referenciais da psicologia do desenvolvimento humano no atendimento a crianças e adolescentes diagnosticados com TEA ou com outros transtornos do desenvolvimento.
} 
vezes na semana. Na ocasião optamos que ele fosse atendido por mim e por uma outra psicóloga da equipe, em dias diferentes.

Nos encontramos para a primeira conversa na casa deles. Gustavo ficou na sala, conosco, ora tentando pular no sofá, ora vendo um livro de arte em inglês sobre o desenho Madagascar. A demanda da família quanto ao atendimento era clara e ampla: auxiliar Gustavo a ampliar o contato social, progredir nas interações sociais, colaborar no desenvolvimento da fala e dar um retorno das sessões para a família.

Um menino magro, de cabelo liso, curto e escuro. Olhos de jaboticaba. Sério, como o pai, exceto por um leve sorriso que vez ou outra deixava escapar. Pai e mãe relatavam sua paixão pelos livros, embora não fosse preciso nos dizer, pois ele mesmo já tinha nos mostrado, ao ver aquelas imagens com tamanha atenção e tentar reproduzir o nome de alguns dos personagens.

Gustavo estudava em escola regular, perto de sua residência, conseguia falar com clareza algumas palavras, vocalizava e dava pequenos gritos com frequência. Tinha uma irmã recém nascida, e estava ainda se familiarizando com ela! Havia iniciado, também, o processo de desfralde recentemente, e alguns "escapes" ainda estavam acontecendo.

Iniciamos os atendimentos, e ao final daquele semestre os trabalhos de Gustavo com a psicanalista foram suspensos pela família. Os pais de Gustavo consideraram que ele não estava progredindo conforme o esperado e que o retorno que recebiam da profissional sobre o que estava sendo trabalhado nas sessões não lhes era suficiente.

Quando já estávamos com Gustavo há 8 meses (ele estava com quatro anos nesta época), propusemos à família que ele fosse atendido uma vez na semana apenas por mim e, na sessão da outra psicóloga de nossa equipe, que já estava o atendendo, eu participasse também. Pensamos isso porque após as sessões iniciais e no decorrer das demais, notamos que Gustavo muitas vezes não aceitava uma nova brincadeira ou modificação ao que estava acostumado a brincar porque não entendia a proposta que estávamos fazendo. Era como se ele não nos desse tempo para explicar ou mostrar, logo recusando e voltando ao que já lhe era familiar. Com duas terapeutas numa mesma sessão, teríamos a oportunidade de mostrar a ele o que estávamos sugerindo e possibilitar que ele escolhesse, após observar, se gostaria ou não de participar. Os pais de Gustavo aceitaram, e seguimos com os atendimentos desta forma.

Sete meses depois, quando Gustavo estava com 4 anos e 7 meses, por recomendação nossa a partir de observações que fizemos no decorrer das sessões, foi feita uma avaliação sobre seu perfil sensorial, pois ele se mostrava muito sensível a alguns sons, aparentava ter baixo 
tônus muscular, além de apresentar dificuldades em relação a motricidade fina e grossa. Não chegou a dar início a um tratamento com profissional da área de terapia ocupacional.

Aos 4 anos e 8 meses, isto é, após oito meses do início da sessão com duas terapeutas uma vez na semana, sugerimos aos pais que, uma vez por mês, uma dessas sessões fosse realizada em ambiente externo, para que Gustavo pudesse ter contato com outros ambientes e que nós pudéssemos auxiliá-lo quanto à interação social e compreensão de contextos diferentes. $\mathrm{Na}$ época, os pais haviam nos relatado algumas dificuldades em sair com o filho, por exemplo, ao shopping, pois este tinha dificuldade em compreender que não era possível comprar e levar para casa tudo o que ele gostaria.

Quando Gustavo estava com 4 anos e 10 meses, em consulta com um segundo neurologista, foi fechado o diagnóstico de TEA e a família recebeu a recomendação de iniciar um trabalho com psicólogos e fonoaudióloga da abordagem comportamental.

O trabalho com a primeira fonoaudióloga de Gustavo foi encerrado, e então iniciado com a recomendada pelo médico. A mãe dele fez uma reunião comigo e com a outra psicóloga da nossa equipe, e disse que ela e o marido haviam conversado e gostariam de manter o nosso trabalho e iniciar o de terapia comportamental; que eles sabiam que eram terapias diferentes, mas que o Gustavo gostava muito de nós e da terapia conosco, que ele perguntava todos os dias por nós, e ela não queria interromper. Ela gostaria que continuássemos trabalhando a parte de interação social, jogos e brincadeiras, e aspectos afetivos, e que fosse acrescentado o trabalho comportamental para as atividades de cunho pedagógico, uma vez que esta demanda naturalmente cresceria na escola.

Depois de muito pensar e conversar entre nós, da equipe, chegamos à conclusão que daríamos, sim, continuidade ao atendimento de Gustavo, por ele. Pelo vínculo forte e de confiança que tínhamos estabelecido, e por apostarmos na nossa relação que estabeleceríamos para que pudesse progredir em outros campos, com outras pessoas. Acordamos com os pais, apenas, que nós pudéssemos continuar com autonomia sobre o nosso trabalho, uma vez que sabíamos previamente que a abordagem comportamental tende a ocupar todas as esferas da vida da criança para se fazer efetiva.

Então, aos 5 anos de idade Gustavo fazia terapia conosco duas vezes na semana, terapia comportamental outras duas vezes na semana e fonoaudiológica mais duas vezes. Além disso, fazia também natação, e frequentava escola regular com acompanhante terapêutica orientada pelo psicólogo comportamental (devido à dificuldade de permanecer com o grupo em sala e necessidade de adaptação de algumas atividades pedagógicas). 
Quando ele estava com, aproximadamente, 6 anos, e sua irmã, Luana, com 3 anos, seus pais pediram que ela pudesse participar um pouco das nossas sessões, quando estávamos em duas terapeutas, para auxiliar na interação entre os dois. Foi um momento muito interessante do nosso trabalho com Gustavo; embora de muita tensão em algumas situações, conseguimos manejar a vontade de participar e dar ordens de uma, e a insubordinação do outro!

Nessa mesma época Gu fez o ADOS pela primeira vez e uma nova avaliação de Integração Sensorial.

Aos 8 anos Gustavo ainda estava com a terapia comportamental em casa duas vezes na semana e a mesma fonoaudióloga, mas uma vez na semana, pois uma outra fonoaudióloga voltada para a motricidade oral ingressou no trabalho com ele. Nesse momento, de nossa terapia com ele, passamos a fazer atividades cotidianas externas como ir ao mercado, comprar um presente no shopping, ir ao cinema, para que pudéssemos trabalhar juntos a interação social, a memória de trabalho, a sequência de tarefas, entre outros aspectos.

Com 9 anos, Gustavo não estava mais com fonoaudióloga comportamental, apenas com a de motricidade oral, duas vezes na semana. Ela começou a auxiliá-lo também na alfabetização. Com esta idade, ainda, Gu e eu passamos a frequentar uma oficina de marcenaria, para que ele conseguisse organizar seu corpo no espaço, e também a perceber o sequenciamento e o encadeamento de ações necessárias para a execução de uma tarefa. Paralelamente a esse trabalho, a outra psicóloga de nossa equipe continuou com as sessões em casa com ele, ora com e ora sem a irmã. Pouco tempo depois, o trabalho com o terapeuta comportamental foi encerrado.

Com essa formação final de equipe (duas psicólogas e uma fonoaudióloga), seguimos até o presente momento.

\subsubsection{Sobre o desenvolvimento de Gustavo durante o atendimento}

Iremos apresentar agora um panorama geral sobre como Gustavo estava antes do nosso trabalho com ele, nas principais áreas associadas ao autismo (comunicação e linguagem, interação social, brincadeiras e imaginação, interesses restritos e comportamentos repetitivos), e como ele foi se desenvolvendo. Os dados foram retirados dos nossos relatórios de acompanhamento e de relatórios escolares.

Inicialmente Gustavo fazia pouco contato visual espontâneo, com curta duração. Apresentava breves expressões faciais, guiava nossa mão para o que ele gostaria que fosse feito 
e apontava. Ele apresentava um vocabulário pequeno de substantivos, e algumas outras palavras que não era possível reconhecer por conta de sua dicção. Aceitava a presença de outras pessoas no mesmo espaço que ele e permitia o contato físico (abraço, cócegas, colo). Tinha uma brincadeira rígida, permitindo poucas variações, mesmo que periféricas à brincadeira central. Pouco interesse pelo outro e pela ação deste, ficando mais centrado ao que habitualmente estava acostumado a fazer, ou modo de brincar ou interagir. Gustavo apresentava brincadeira imaginativa, e tinha alguns interesses específicos como livros, filmes, e carros do filme Carros, da empresa de animação digital Pixar.

Em relação aos aspectos motores, demonstrava preferência por atividades em que permanecia sentado, mas tinha abertura para atividades físicas mais gerais, amplas, envolvendo o corpo todo. Não gostava de pintar e/ou desenhar, e tinha baixo tônus nas mãos.

Quando ficava feliz, deitava em locais macios (preferencialmente), deixava os braços e pernas em 90 graus em relação ao corpo, e balançava os pés e as mãos. Por vezes, as mãos se encostavam e faziam movimento de rotação no próprio eixo. Em alguns momentos não chegava a deitar, apenas levantava os braços e fazia o movimentos com as mãos. Nas duas ocasiões, esses movimentos eram acompanhados por um som vocalizado.

Após 3 meses de atendimento, Gustavo, com então três anos e sete meses, começou a demonstrar interesse pelos objetos que levávamos para a sessão dele, e quando fazíamos pausas na brincadeira, e suspendíamos nossa interação, ele passou a pedir que continuássemos. Ele também começou a nos imitar espontaneamente em relação a gestos e sons.

Após 8 meses de atendimento, Gustavo, com quatro anos, passou a falar usando alguns verbos e adjetivos, e a pedir ajuda quando julgava necessário. Passou a responder perguntas simples e comunicar o que queria e o que não queria. Começou a permitir alterações periféricas em suas brincadeiras, e a se interessar por jogos de encaixe.

Após 10 meses, estava apresentando uma resposta mais rápida quando chamado pelo nome, fazendo contato visual imediato; criando pequenos diálogos com carros e bonecos, fazendo uso de pequenas frases; mais persistente nas atividades que envolviam coordenação motora fina; estava permitindo ser ajudado sem ficar bravo.

Em um ano, Gustavo, com quatro anos e quatro meses, se apresentava mais disponível e curioso para as brincadeiras. Estava mais atento ao que fazia, chamava-nos para participar de sua brincadeira, e até mesmo dava objetos para que pudéssemos fazer parte dela, de forma mais efetiva. Em relação à motricidade grossa, já estava correndo no parquinho quase sem cair, e era nítida a segurança ao subir e descer dos brinquedos. Começou a estruturar melhor as histórias 
que criava e a enriquecê-las com diversos elementos. Ele tomou gosto pela história dos Três Porquinhos, e a reproduziu com a nossa ajuda de diversas formas, até mesmo como teatro, o que o ajudou a compreender as narrativas, de um modo geral. Na maioria das vezes passou a nos olhar ao falar, e até mesmo a fazer sugestões para brincadeiras que costumava fazer quase sempre do mesmo jeito.

Em um ano e meio de atendimento, quando introduzimos os passeios, estes foram muito motivadores para o Gustavo, ele estava com quatro anos e dez meses. Ele dizia palavras e frases inéditas, e foi ocasião para que ele chamasse nossa atenção para o que estava vendo, e até mesmo a nos contar fatos de seu cotidiano conforme o caminho que fazíamos (ao passar próximo de sua escola, ele disse "Meninas! Foi na escola!", nos dizendo que ele tinha ido para a escola). Também começou a ser sociável com pessoas desconhecidas, cumprimentando e dizendo seu nome para se apresentar. Nas sessões, parecia estabelecer relações entre cenas e personagens, distinguir bem e mal, e estava mais interessado e insistente em desenhar e pintar. Em relação à coordenação motora grossa, estava propondo desafios a si mesmo no parquinho, e ficando muito satisfeito por conseguir realizá-los.

Com dois anos e meio de atendimento, $\mathrm{Gu}$ (com cinco anos e dez meses) estava muito mais comunicativo e buscando interação. O contato visual havia aumentado em frequência e duração, embora ainda precisasse de estabilidade; ele buscava não mais a nossa presença, mas também participação em todas as suas brincadeiras; estava indo ao encontro de crianças em espaços públicos, se apresentando, e brincando próximo e, às vezes, até emprestando seus brinquedos. Em relação à motricidade fina e à organização visuoespacial, estava se interessando cada vez mais por quebra-cabeças.

Nessa mesma época fizemos a ADOS, que apontou a classificação de autismo, com o nível moderado de sintomas associados ao transtorno. Das três áreas avaliadas (comunicação, interação social recíproca e comportamentos repetitivos e restritos), Gustavo pontuou em duas: interação social e comportamentos repetitivos. Isto é, ele ainda apresentava dificuldade quanto ao contato visual, expressão facial direcionada a outros, integração do olhar com a fala em aberturas sociais e iniciação espontânea de atenção compartilhada, além do uso estereotipado de palavras e frases, maneirismos com as mãos e interesse repetitivo. Esses pontos destacados na ADOS nos serviram como norte a respeito do que precisaríamos trabalhar mais com ele, e assim o fizemos a partir daquele momento.

Aos quatro anos e meio de atendimento, Gustavo (sete anos e dez meses) já estava conseguindo integrar o contato visual e a fala em aberturas sociais, principalmente nas que 
envolviam um pedido, e estava iniciando espontaneamente mais momentos de atenção compartilhada. Nessa fase do atendimento, estávamos indo para muitos lugares, e ele era quem estava encarregado de comprar o lanche ou o ingresso do passeio. Ele já conseguia entender que para que ele tivesse o que queria, teria que pedir para alguém, de forma específica, e dar um dinheiro. Que teria que aguardar por seu pedido na fila ou no lugar delimitado; e assim conseguiria o almejado.

Com cinco anos de atendimento, Gu (oito anos e quatro meses) já conseguia entender o mecanismo do mundo fora de sua residência. Ainda falava um pouco alto em relação ao que é esperado nos ambientes sociais, mas já conseguia ver mapas, se orientar no espaço, e participar das regras sociais. Entretanto, algo chamou nossa atenção: após comprar no mercado frutas e voltar para casa para fazer uma salada de frutas, Gustavo não entendia o procedimento, mesmo após este ser mostrado por figuras, e o mesmo aconteceu em relação a fazer o suco para o lanche. Nós o auxiliamos pontualmente, mas isso ficou como um alerta. Em reunião com a fonoaudióloga, de certa forma a mesma dificuldade aparecia: ele reconhecia as letras, mas não conseguia lê-las juntas, ele sabia uma história, mas não conseguia recontá-la.

No sexto ano de atendimento, nossa proposta foi que Gustavo (nove anos e quatro meses) frequentasse, com nosso acompanhamento, a oficina de marcenaria. A ideia era que ele pensasse em algo que quisesse construir, e tivesse que ele mesmo fazer essa construção. Para isso, teria que usar o planejamento, entender uma sequência, e mais: aprimorar seu tônus e motricidade fina. Em sua casa a outra psicóloga de nossa equipe faria um trabalho de auxiliálo a recontar histórias por meio de desenhos, criar histórias com começo, meio e fim, e apresentar a ele jogos que envolviam raciocínio lógico. Sua família passou a montar com ele conjuntos de Lego, e quebra-cabeças variados, cada vez com mais peças.

Assim seguimos. O primeiro projeto de Gustavo na oficina foi o carro de corrida de um personagem de desenho chamado Pocoyo. Levei a imagem do desenho para que tivéssemos uma referência; o professor sugeriu um trabalho a partir de um bloco de madeira; Gustavo só queria pintar o bloco de vermelho, como se bastasse isso para que o carro todo ficasse pronto. Explicamos isso para ele. Eu fiz um registro fotográfico de cada etapa do processo, com ele mesmo fazendo. A cada semana nós víamos todos os passos dados até então, e dávamos continuidade. A pergunta era sempre "E agora, Gu, o que está faltando para ficar igual ao carro do Pocoyo?". Ele respondia sobre um ou outro aspecto, nós complementávamos e seguíamos. Ao final do projeto, ele tinha o objeto que havia construído e um livro com imagens de cada passo e uma narrativa em primeira pessoa, com todos os processos enumerados. 
No sétimo ano de atendimento, e segundo ano de oficina com Gustavo (dez anos e quatro meses), ele já consegue dizer: "Luisa! Falta o olho, a sombrancelha, o nariz, a boca e a orelha. E falta o rabo!". E também conseguia responder quando perguntado sobre o material que utilizará para determinado projeto: "Eu quero madeira. Pelúcia, não!”. Ele tem se antecipado quanto ao que deve ser feito e dirige-se sozinho, com autonomia, para separar o material. Ele observa o projeto de outras crianças que fazem aula no mesmo horário que ele, e por vezes ajuda em alguma parte, principalmente quando é para pintar ou lixar, pois ele gosta muito disso. O projeto fotográfico continua, mas agora, o livro só é apresentado a ele ao final, e ele vê e lê cada página com muito orgulho. A leitura? Sim, Gu está lendo e compreendendo muito bem. Escreve também.

A oficina tem favorecido muito o tônus das mãos e da motricidade fina. E um ponto muito positivo e inegável nesse processo todo é a persistência dele nas etapas do projeto que exigem mais atenção, concentração e motricidade. Ele não aceita que alguém faça por ele, ou mesmo que o ajude "demais" em determinadas tarefas. Ele quer fazer. Ele quer conseguir. Ele quer aprender.

Sobre os movimentos repetitivos com pés e mãos, Gustavo ainda os faz em alguns momentos, quando está muito feliz. Entretanto, já não deita mais em locais públicos e, por vezes, balança apenas as mãos.

Ele tem se comunicado melhor verbalmente, e feito contato visual ao falar. Ainda é um garoto que fala pouco, e compartilha pouco do que vive internamente. Em alguns momentos ele ainda nos conta diálogos de filmes que lhe ocorrem na cabeça, e quando perguntamos de qual filme é, e qual personagem, ele responde sem titubear. Podemos dizer que ele não passa aperto: sabe ser sociável; sabe dizer quando dói e o que dói; que sente saudade; daquilo do que gosta e do que não gosta; o que quer e o que não quer. Ele se expressa no que para ele é importamente que os outros saibam.

\subsubsection{Cenas}

Especificamente no caso do Gustavo, revendo as cenas selecionadas, percebi que poderia ser mais interessante um comentário único que agrupasse todas as cenas uma vez que não há um destaque que se possa fazer em cada uma delas que seja específico da esfera cognitiva, outro da esfera da linguagem, outra da coordenação motora, outro da imaginação. E também porque elas todas parecem se organizar em torno dos efeitos da própria interlocução 
terapêutica no que diz respeito ao poder dizer de si, de suas intenções, de suas limitações, de suas demandas, vontades, entre outros.

Em muitas das cenas aqui descritas eu me coloquei na posição de quem precisava apenas colocar as palavras para dizer daquilo que os gestos e as ações do Gu mostravam. Foi um trabalho bastante "colado" que podemos chamar de discurso-ato ${ }^{28}$, que enredava o Gugu nas cenas vividas.

É como se ele estivesse aprendendo a dizer de si e, nisto, minha palavra muitas vezes dizendo o que eu acreditava que ele estava sentindo/querendo/pensando pareceu fundamental para $\mathrm{Gu}$, porque o que ele fazia era continuar o que eu estava dizendo, por meio de atos, ações.

Em algumas cenas pode parecer que há um sincretismo, mas não é isso. Ele faz como uma apropriação do sentido do que lhe é dito. E quando eu descrevo para ele o que ele fez, parece ter um efeito de reorganização afetiva. Essa sequência se repete muito; de ele alçar o sentido que as palavras que eu digo têm para ele, e então, continuar e colaborar.

Nas cenas, é possível notar que a demanda inicial dos pais em relação ao nosso trabalho, de que fosse desenvolvido o contato, a interação social e a fala, foi por nós atendida de um modo orgânico e não sectário, em sessões para desenvolver uma ou outra esfera. Tudo parecia se entrelaçar no fazer/acontecer de cada encontro com o Gu.

A estratégia com ele foi a de uma interlocução que permitiu que ele dissesse de si.

Deixo, agora, que o leitor acompanhe a interlocução desta dupla nas cenas que se seguem.

Cena 1

(...) Como ele estava falando alguns verbos hoje, ao vermos alguns livros juntos eu tentei introduzir além do nome da figura, alguma ação, como: O Woody está voando! O Buzz está sentado! Ele não repetiu e eu também não solicitei. A intenção foi de a começar a apresentar verbos e relacioná-los aos sujeitos. (Anotações pessoais, um ano e dois meses de atendimento, Gustavo com quatro anos e seis meses)

A brincadeira com o Woody e o Buzz hoje foi bem divertida. Ele começou falando que eles iam voar, depois eu comcei a cantar a música do Woody e ele ficou super feliz, repetiu "amigo estou aqui" comigo, e foi acrescentando à brincadeira, espontaneamente, as comidinhas de plástico e o carro. Então, eu fiz para a nossa brincadeira um túnel com as almofadas e o sofá em que ele conseguia passar, e disse que iríamos fazer um piquenique depois que atravessássemos o túnel. Primeiro ele atravessou sozinho, e quando eu falei que ele tinha sido muito corajoso, ele olhou para mim e sorriu. Depois, voltou e levou o Woody e o Buzz, e ao chegar do outro lado falou "caiu o túnel", e então eu apertei as almofadas contra ele e fiz cócegas, e ele deu gargalhadas. Ele ficou muito feliz com a brincadeira, e quis repetir algumas vezes. (Anotações pessoais, um ano e três meses de atendimento, Gustavo com quatro anos e sete meses)

\footnotetext{
${ }^{28}$ Conforme apresentamos nas fundamentações conceituais desta tese.
} 
Esta cena nos mostra: minha influência na brincadeira dele (cantar); a aceitação dele à minha entrada (sorriu e repetiu o nome da música); uma colaboração mútua para o desenvolvimento da brincadeira; a entrada dele na minha proposta (túnel); minha aceitação à proposta dele e continuidade em sua sugestão.

Cena 2

Quando brincamos com a bolha, ele quis fazer sozinho algumas vezes e eu deixei. A princípio, ele não conseguia assoprar, mas depois, aos poucos, foi conseguindo, até que fez várias! Então, eu me coloquei no lugar dele, estourando e pedindo bolhas grandes e pequenas. (Anotações pessoais, um ano e dois meses de atendimento, Gustavo com quatro anos e seis meses)

Aqui conseguimos acompanhar como uma habilidade foi desenvolvida (assoprar) e, na inversão dos nossos papéis na brincadeira, minhas ordens eram ocasião de um controle dele sobre o próprio movimento, e sobre seu próprio corpo.

Cena 3

(...) Nós fomos lavar as mãos pois estavam com sabão das bolhas, e ele quis brincar com o sabonete. Brincamos um pouco e eu falei para ele que iríamos parar e voltar a brincar no quarto. Ele resmungou um pouco mas aceitou. Mas, assim que voltamos para o quarto, ele começou a colocar na boca as peças do jogo das caretas, e aí eu falei para ele que entendia que ele talvez estivesse bravo comigo, pois queria ter brincado mais tempo com a água, mas que "comer" as peças não ia ser bom para ele. Disse também que se ele estava comendo as peças para me mostrar que tinha ficado bravo, eu estava entendendo e ele poderia parar de comê-las. Ele parou imediatamente, pegou o Buzz e começou a brincar de voar com ele. (Anotações pessoais, um ano e três meses de atendimento, Gustavo com quatro anos e sete meses)

Essa descrição mostra que eu não tratei o ocorrido como birra, oposição, mas como forma de comunicação. Ao colocar as palavras que me pareceram encenar afetos, demandas e comunicação de uma ideia em jogo, a tensão pareceu, então, se diluir.

\section{Cena 4}

(...) Quando ele quis desenhar, puxou a cadeira e sentou na mesa com os papéis e canetinha, e eu fiquei sentada no chão ao lado dele. Então, Gu se levantou, colocou uma outra cadeirinha ao lado dele para que eu pudesse sentar também. (Anotações pessoais, um ano e três meses de atendimento, Gustavo com quatro anos e sete meses)

Temos aqui um retrato da nossa parceria e a demanda de Gu pela minha presença neste lugar de igual. 


\section{Cena 5}

(...) Após uma hora de sessão, ouvimos a Luana chorar. Então, Gu parou e disse: “A Luana! A Luana está dormindo!”. Eu falei para ele que ela estava chorando. Ele repetiu o que eu disse, eu perguntei se ele queria ir vê-la e ele disse que sim. Nós fomos. Chegando lá, ele disse “Oi, Luana!” encostou na mão dela e voltou correndo para o quarto. (Anotações pessoais, um ano e quatro meses de atendimento, Gustavo com quatro anos e oito meses)

Esta cena demonstra a tensão tão presente na vida de $\mathrm{Gu}$, entre o gesto e a palavra. Eu nomeio o que julgo ser a sensação dele, ele aceita e parece se autorregular com isso. Ele vai, vê a irmã, e vai embora. Ao fazer isso, ele está dizendo em ato, que ir ali, olhar, falar "oi" e encostar nela, é o suficiente. Há uma reorganização afetiva facultada. O discurso mostra: eu volto com ele para o quarto, aceitando o jogo. Bastou para ele, bastou para todos.

\section{Cena 6}

Hoje, em todas as vezes em que o Gu jogou os brinquedos no chão quando não queria mais brincar, eu falei para ele que não precisava jogar, ele poderia simplesmente guardar. Então, após escolher um livro de pintar entre outros, antes de jogar os demais no chão, eu falei para ele que se ele não quisesse os outros, poderia guardar. Imediatamente, ele guardou, incluindo todos os outros brinquedos! (Anotações pessoais, um ano e quatro meses de atendimento, Gustavo com quatro anos e oito meses)

Aqui, o ato de colaboração dele confirmou o sentido da proposta que lhe fora feito.

\section{Cena 7}

(...) Por volta das 15:20 ele quis sair do quarto para tomar lanche na cozinha. Pegou a chave, colocou na porta, e ficou esperando que eu abrisse. Eu pedi para ele me falar o que ele queria que eu fizesse e ele não disse. Voltamos a brincar, e passado um tempo ele voltou até a porta e disse "coloca", segurando a chave. Dessa vez eu perguntei "Abrir?" e ele completou "A porta!". (Anotações pessoais, um ano e sete meses de atendimento, Gustavo com quatro anos e onze meses)

Temos nesta cena o dizer de si provocado, completando os sentidos a partir da palavra dada de fora por mim.

\section{Cena 8}

(...) Assim que montamos a casinha ele entrou super feliz e rápido, e bateu a cabeça na parede, e começou a chorar. Peguei ele no colo, perguntei onde estava doendo, onde ele tinha batido, e ele disse "a cabeça" e mostrou onde era, colocando a mão. Eu fiz um carinho e disse que iria passar. Perguntei, depois, se ele queria gelo e ele respondeu que sim. Fui buscar, e quando voltei ele deixou que eu colocasse por bem pouco tempo o gelo e logo disse "está tudo bem". 
(Anotações pessoais, um ano e sete meses de atendimento, Gustavo com quatro anos e onze meses)

Aqui, uma cena que apresenta a interação de cuidado mostrada e falada.

\section{Cena 9}

(...) Quando eu estava indo embora, guardei algumas coisas e fui até minha mochila pegar o computador. Enquanto fazia isso, $\mathrm{Gu}$ ficou agitado, percebi ele se movimentando muito atrás de mim. Quando me virei para ele, ele havia feito um cerco ao meu redor com o puff e a poltrona. Eu falei para ele que parecia que ele não queria que eu fosse embora, e que eu também não queria ir. Disse que iria escrever no computador ainda, e sentei na poltrona. Gu sentou junto comigo na poltrona, mas depois saiu, ligou a televisão e foi para o sofá. Eu coloquei de volta a poltrona e o puff e expliquei que estava arrumando para que não ficasse na frente da televisão. Escrevi um pouco mais no relatório e depois levantei, guardei minhas coisas, fui até ele e pedi que ele me desse tchau. Ele me deu um abraço, levantou comigo e começou a dizer “Ai, ai, ai!". A babá perguntou "Você não quer que ela vá embora?", mas ele não respondeu. Eu disse que logo logo eu voltaria e que nossa brincadeira seria bem divertida. Dei um beijo nele e fui embora. (Anotações pessoais, um ano e sete meses de atendimento, Gustavo com quatro anos e onze meses)

Nesta cena temos comunicação e interação. Eu levantei uma hipótese da disposição física das coisas e ele poderia confirmar ou não, e ele confirmou, vindo sentar comigo.

Quando eu me despeço e peço para que ele me dê tchau, ele responde com gesto (abraço) e também traz a possibilidade de dizer de si (“Ai, ai, ai!”) e de complementar esse dizer pelas suas palavras.

Cena 10

No começo ele estava estranhando nós duas juntas; ficou brincando com os carrinhos sem interagir com a gente. Enquanto isso, montamos uma pista com papel craft, desenhamos, ele colou os adesivos do Carros (pediu ajuda para tirar os adesivos da cartelinha) e nós criamos um túnel de papel e uma rampa com as almofadas. A gente falou para ele que era a pista Copa Pistão e começamos uma corrida com dois carrinhos. Inicialmente ele ficou olhando, com atenção, a nossa brincadeira e depois quis participar também; correu com o McQueen e outros carros, achou divertido. Pouco depois pediu para montar a casinha, nós montamos uma bem grande e chamamos de "estacionamento" e "casa dos carros". Os carros faziam o seguinte percurso: Luisa mandava os carrinhos para a Fabi perguntando "Pode mandar?", Fabi respondia "Pode!", recebia os carrinhos e perguntava para o Gugu "Pode mandar?" que, após algumas vezes vendo nossa comunicação, respondeu “Pode!”. Depois de mandarmos para ele todos os carrinhos, espontaneamente ele mandou de volta! Em determinado momento o $\mathrm{Gu}$ foi até o banheiro e voltou para o quarto com um grande pedaço de papel higiênico e colocou como uma continuação da pista para chegar à casinha. Ficamos muito felizes com essa iniciativa dele e chamamos de "caminho", palavra que ele repetiu e gostou de falar. Ajudamos a colar o papel higiênico no chão, e depois substituímos por papel craft pois o papel higiênico estava ficando rasgado! (Anotações pessoais, um ano e oito meses de atendimento, Gustavo com cinco anos) 
No começo desta cena podemos notar que Gu seguia, ainda que à distância, os movimentos e brincadeiras provocadas pelas duas terapeutas. Uma espécie de convite à sua aproximação... Logo ele responde e se diverte com a brincadeira conjunta. Chama a atenção que ele "guia" o desfecho da sessão, como o fez nas cenas anteriormente descritas.

\section{Cena 11}

(...) Em determinado momento a Fabi estava sentada em cima, na casinha, e eu ajudava o Gugu a subir e dar "oi” para a Fabi. Depois de um tempo, ficamos nós três sentados na casinha, até que a Fabi desceu, eu fiquei sentada e o Gu no meu colo. A Fabi assustava o Gugu e ele se escondia em mim! Depois, o Gu levantava, procurava a Fabi, e quando ela ia atrás dele, ele corria e se escondia em mim. Em um momento eu tentei levantar, trocar de lugar, e o Gugu disse "Senta! Senta!", apontando o lugar para eu ficar sentada! Eu fiquei, depois desci com ele no escorregador, ele subiu, olhou para mim e disse novamente "Senta! Senta!". A Fabi solicitou que ele dissesse "Senta, Lu", e ele repetiu rapidamente! Eu subi e sentei, a Fabi subiu e sentou, e então ele segurou a minha mão e a mão da Fabi e disse "as duas!!!" e foi nos puxando para descer pelo escorregador e nos levou até a brinquedoteca. (Anotações pessoais, um ano e nove meses de atendimento, Gustavo com cinco anos e um mês)

\section{Brincadeira. Parceria. Movimento conjunto de elaboração ${ }^{29}$.}

Cena 12

(...) Enquanto eu montava a pista ele mexia nas peças menores com muita atenção, até que falou "Qué paquinho! Qué paquinho!". Combinei com ele que iríamos guardar tudo e depois desceríamos, e embora ele não tenha me ajudado a guardar, esperou ao meu lado. Deu para eu segurar todos os carrinhos e nós fomos!

(...) Propus, então, que levássemos os carros para o escorregador, e ele aceitou na hora, sorrindo! De cima do escorregador o Gugu mandava os carros para mim, que estava embaixo com um colchão para não "machucar" os carros. Eu ia narrando o que estava acontecendo, qual carro iria descer o escorregador, se tinha ido muito longe no colchão ou não, e o Gugu dava risada, sorria. Depois de um tempo, ele passou a jogar todos os carros e por último ele descia. Então, quando ele chegava no colchão eu levantava ele e falava "o graaaaande piloto chegou!!!", e ele adorou! Passou depois a falar "piloto", muito bacana!

Quando a sessão ia terminar, eu falei para ele que estava gostando muito da nossa brincadeira, mas que eu precisava subir, pegar as minhas coisas e ir embora. Ele disse várias vezes para mim “não qué!", e segurou minha mão pedindo para ficar. Falei que brincaríamos mais uma vez, que seria a última, e então subiríamos. Depois disso, ele continuou sem querer subir, mas fui levando-o pela mão para a escada e fomos. Notei que a cada vez que ele resistia subir ou andar e eu falava "eu também queria ficar mais", ele voltava a subir as escadas, ou a andar. Parece que perceber que eu também queria, e que eu estava notando que ele não queria subir, o acalmava.

(...) A sessão de hoje foi muito importante por ele propor uma brincadeira e um espaço. Além disso, as propostas feitas por mim como variação na brincadeira dele foram aceitas, o que mostra uma confiança e uma grande flexibilidade! (Anotações pessoais, um ano e nove meses de atendimento, Gustavo com cinco anos e um mês)

${ }^{29}$ Esta situação foi acrescentada aqui por sua estética no sentido próprio do termo de Michel Foucault: mostra um trabalho de si sobre si mesmo, elaborando e transformando para atingir um certo modo de ser. (Foucault, Ditos e Escritos - Ética, Sexualidade e Política, 1984/2004) 
Nesta cena, Gu demonstra prazer na brincadeira, entra na minha proposta de imaginação, contribui com a brincadeira, também faz falas que descrevem suas ações (assim como eu fiz tantas outras vezes!) e dizem expressamente de sua demanda.

\title{
Cena 13
}

Enquanto ele pegava os carros, eu peguei nos brinquedos dele um saco que tinha alguns piratas, navios, fundo do mar. Assim que peguei, eu o chamei para brincar e ele olhou na hora, e no mesmo instante se aproximou para brincar. Tentei montar, mas não consegui, e ele ficou ao meu lado tentando montar também! Quando concluí que talvez não desse para montar tudo, eu peguei o tesouro e falei que ele ia ser o Capitão Gugu e eu a Marinheira Luisa, e nossa missão era encontrar o tesouro! Ele deu risada, nós ficamos em cima de um quadrado do tapete branco, e eu comecei a movimentar fazendo barulho de água. Foi muito divertido, ele olhava para fora do tapete-barco, como se tivesse mar mesmo! Uma das vezes ele mergulhou para fora do barco, eu mergulhei também, e nós encontramos o tesouro, que estava escondido no fuuuuundo do mar! (Anotações pessoais, um ano e onze meses de atendimento, Gustavo com cinco anos e três meses)

Temos aqui uma cena em que fica clara a força da ação e da palavra para dar suporte à imaginação.

\section{Cena 14}

\begin{abstract}
Quando terminamos a casinha, eu desenhei notas musicais saindo da janela e falei que era uma "casa-musical", e começamos a cantar a música da casa. A Fabi, no meio da música, pegou o violão e eu uns potinhos para acompanhar. O Gugu gostou, ficou animado, e sentou-se no sofá para ver! Ao final da música ele disse "Muito bem, meninas!!!". Risos. Perguntamos se ele queria outra música, ele disse "outra", e a partir daí cantamos várias. Ele ficava no sofá sentado, batia palma e cantava em algumas, e ao final sempre comemorava dizendo "muito bem" ou "parabéns!". (Anotações pessoais, dois anos de atendimento, Gustavo com cinco anos e quatro meses)
\end{abstract}

Nesta cena, Gu inverte o lugar de diretor de cena e plateia. E nessa inversão, ele é quem dá a palavra!

Cena 15

Encerro a apresentação da terapia do Gu com uma cena que reúne todos os elementos apontados anteriormente, sobretudo, a condição dele de dizer de si, de suas demandas, de dirigir a situação para o que vai elaborando de suas competências e suficiências em situações que lhe são desconhecidas e para as quais lhe basta ter um interlocutor que possa ouvi-lo pelo que fala e faz. 
- Lá não vai ter batatinha, vai ter livros! Você está comendo manga agora para não ficar com fome lá.

- Eu não quero livro, quero batatinha!

- Nós podemos ir amanhã comer batatinha. Hoje nós vamos ver livros, que você tanto gosta!

Gugu termina de comer a manga, e nós vamos saindo. No elevador temos a seguinte conversa:

- Gugu, a gente vai na USP! É muito legal lá!

- USPital?

- Não, não! USP, Universidade de São Paulo!

- USP! USP!

- Isso! Lá é uma escola para adultos. Qual é o nome da sua escola?

- AB! Minha escola é AB!

- Isso! E a minha é a USP! Hoje você vai conhecer a minha escola! E nós vamos ver livros lá!

- Livros! (sorrindo)

No carro, no trajeto para a Feira, passamos pelo Carrefour. Assim que passamos pelo nome do supermercado, Gugu fala:

- Não! Não! Não, Luisa! A batatinha!!!!

- Eu sei Gugu, esse é mesmo um supermercado que a gente vai e você costuma querer compra batatinha! Mas lembra, nós estamos indo pra USP!!! Nós vamos na Feira do Livro hoje!

Gugu mostra-se animado: solta algumas risadas, faz movimentos com as mãos, balança os pés no caminho.

Entramos pelo Portão 2, e assim que passamos por ele, eu digo:

- Gugu, tudo que a gente vir daqui pra frente é a USP! Tudo isso que nós estamos vendo agora!

- A árvore!

- É, tá vendo, tem muitas árvores!

- Quanta planta!

- Olha ali aquela caminhonete, ta vendo ali? Está escrito USP, U-S-P, USP.

- U-S-P! USP! (gargalhada)

- Olha Gu, quando eu venho aqui, eu estudo naquele prédio ali, ta vendo?

- Ali!!! (olhando na direção do meu apontar)

- Isso! Mais um pouquinho e chegamos na Feira do Livro! Vamos ver se tem alguma vaga perto...

Faço um retorno e passamos entre a raia e o verde que divide a Avenida Mello Moraes. Gugu olha o verde todo, e diz:

- É o estádio de futebol!!!

- Parece, né, Gugu? É grande e verde!

- Futebol! Brasil!!!

- Isso!

Paro o carro, descemos, atravessamos a avenida e vamos andando beirando o CRUSP.

Gugu segue animado, com um risinho no canto da boca. Quando nos aproximamos das tendas onde ocorre a Feira, ele diz bem alto:

- Luisa! O que é isso!

- Isso são tendas, Gugu! Dentro delas tem um montão de livros para as pessoas verem e comprarem!

Gugu corre um pouquinho, mas sem se distanciar muito de mim e diz para um punhado de gente a nossa frente:

- Olá-a! Meu nome é Gustavo! Eu sou o Gugu!!!

Ninguém de fato ouve o que ele diz, as pessoas estão mais distantes de nós, mas a apresentação está feita! Gugu, USP. USP, Gugu.

Paramos, então, em frente ao painel com o nome das editoras e localizações. Vejo que os livros infantis ficam na tenda Azul. Mostro para ele, aponto o local que devemos procurar, e proponho de irmos pela lateral, pelo lado de fora. Ele aceita, e seguimos! No caminho passamos ao lado do Cepeusp. Gugu olha para o lado, vê uma arquibancada e diz alto:

- É o estádio!!!

- É mesmo, Gugu! Tem um estádio para as pessoas jogarem bola! 
- Olá-a!

- Gugu, fala de novo! Sua voz está ecoando!

- Olá-a! (Olá-a!)

- Viu? É o eco!

- Eco!!! (Eco!!!) Gugu!!! (Gugu!!!)

Chegamos na tenda azul. Paramos na porta e vemos muitas pessoas dentro olhando os livros. Gugu olha também e segura meu braço. Eu digo para ele que temos que entrar e procurar a Brinque-Book! Ele fica animado, e nós vamos! O percurso todo, mesmo com muitas pessoas, Gugu vai junto comigo, segurando em mim espontaneamente. Quando chegamos no espaço dos livros, eu falo para ele que ele pode escolher e olhar o que quiser. Pego um livro, ele pega outro, e começamos a ver e comentar, em pé mesmo!

Fomos andando, folheando, comentando e lendo histórias até o fim da banca da Brinque-Books. Chegando lá, estava mais apertado de gente, era perto do caixa e muitas pessoas estavam organizadas para pagar. Assim que chegamos naquele ponto, Gugu diz que quer ir pra casa. Pergunto para ele se ele não quer comprar um livro. Digo que nós podemos comprar se ele quiser. Pergunto se ele quer levar algum para casa. Gugu só me responde "quero ir pra casa" e ameaça andar sozinho.

Peço para ele esperar, confirmo que nós iremos para casa, e mostro a saída. Ele vai se dirigindo para ela, e quando sai a céu aberto, balança-se em pé, mexe as mãos para cima e faz seu som característico deste momento. Digo para ele que está tudo bem, e que estamos indo para o carro. Ele para seus movimentos repetitivos, e nós vamos andando.

Seguimos, e no caminho pergunto porque ele quis ir embora naquela hora. Ele não responde, então eu dou opções "Você quis sair porque tinha muita gente? Porque estava muito calor? Porque estava muito barulho?". Ele não me responde verbalmente, apenas coloca as mãos nos ouvidos. Eu digo para ele que entendi, que estava muito barulho, mas que já ia ficar tudo bem, porque estávamos indo embora.

No caminho para o carro, novamente pelo CRUSP, Gugu dá risadas, sorri. Eu digo que vejo que ele está feliz, e que apesar do barulho, nosso passeio foi divertido! Gugu sorri ainda mais!

Atravessamos a avenida de volta, ele entra no carro e me diz:

- Eu quero ir para casa!

- Ok, Gugu! Nós estamos indo para casa!

(Anotações pessoais, seis anos e três meses de atendimento, Gustavo com nove anos e sete meses)

Na USP, o encanto com os lugares; a identificação de alguns locais que lhe ocorreram na lembrança, como o estádio de futebol, o Brasil; a autoapresentação ao espaço, até a enunciação da vontade de voltar para casa em função de um possível desconforto que o barulho que a feira lhe causou, diz bastante de todos os desdobramentos que a nossa interlocução permitiu a ele.

Da casa para a universidade, eu guiei o caminho. Da universidade para casa, quem guiou foi ele.

\subsubsection{Henrique}

Todo o atendimento de Henrique foi realizado com a AID. Na ocasião, nós já tínhamos a certificação da escala ADOS, e esta foi aplicada no início e no final do trabalho clínico com ele. Após a finalização do trabalho clínico, Henrique ainda contou comigo por 6 meses em sua 
escola, uma vez por semana, para auxiliar sua acompanhante terapêutica no manejo da relação com ele, e também na estruturação de seu material pedagógico junto à escola.

\subsubsection{Breve histórico}

Henrique nasceu com estenose subaórtica, e passou por algumas cirurgias nos dois primeiros anos de vida para regularizar o fluxo sanguíneo no coração. A mãe relata que com um ano de vida ela já notava que ele era muito agitado e irritável, mas a suspeita de que algo mais grave poderia estar associado veio aos dois anos, quando Henrique ainda não apresentava a fala.

Ele foi diagnosticado por um neurologista infantil com TEA aos três anos, e começou as intervenções com fonoaudiologia e psicoterapia comportamental com três anos e meio. Henrique ainda não falava e batia palmas insistentemente, conforme relatou sua mãe. Ele seguiu com esses profissionais por um ano, tendo atendimento todos os dias.

Após esse primeiro ano de atendimentos intensos, os pais de Henrique se separaram, ele e a mãe mudaram de casa, e Henrique mudou de escola. Adaptados à nova rotina, começaram com o atendimento de psicoterapia comportamental com uma outra equipe, uma vez na semana, e ele passou a ser acompanhado por um outro neurologista infantil. $\mathrm{O}$ trabalho com essa equipe de psicólogos teve duração de mais um ano, quando foi interrompido.

Quatro meses depois dessa interrupção, quando Henrique estava com seis anos e meio, a família nos procurou por indicação de uma amiga da mãe, cujo filho estava em atendimento com a nossa equipe.

Vimos pela primeira vez este menino: alto, bem magro, moreno, de cabelo castanho escuro, cílios longos, e olhar profundo. Animado e agitado; pronto para uma brincadeira, mas não qualquer brincadeira: uma que envolvesse carrinhos do filme Carros, da Pixar, ou mesmo carrinhos da marca Hot Wheels.

Ali estava o Henrique.

Henrique chegou fazendo uso da medicação Ritalina, uma vez por dia, antes de ir para a escola. Pouco tempo depois, o medicamento foi suspenso pela mãe, por não notar diferenças significativas no comportamento do filho, e por efeitos colaterais na alimentação (que já era seleta) e no sono deste.

Acompanhamos Henrique em terapia, duas vezes na semana, por um ano e meio, até seus oito anos, e também o acompanhamos na escola por mais seis meses. Henrique recomeçou 
um trabalho com fonoaudióloga, por sugestão nossa, durante este período. Mas não foi dada continuidade a ele por conta de divergências com relação à condução do trabalho pela profissional escolhida pelos pais.

Ao final do acompanhamento nosso na escola, fizemos a indicação de que houvesse retorno ao neurologista, e pensamos, junto com este profissional e a família, em outras escolas que poderiam ser mais adequadas ao Henrique. Ele mudou de escola no semestre seguinte e o atendimento foi encerrado pela família.

\subsubsection{Sobre o desenvolvimento de Henrique durante o atendimento}

Henrique foi avaliado pela ADOS logo na primeira sessão. Naquele momento, ele usava majoritariamente palavras únicas e ocasionalmente frases, apresentando ecolalia em algumas situações. Demonstrou variação na entonação e tom de voz de maneira peculiar em alguns momentos e, com freqüência, fez uso esteriotipado de palavras e/ou frases. Sua verbalização dirigida à mim e/ou à mãe de modo consistente foi notada apenas em um contexto específico, quando ele queria solicitar algo.

Henrique usou meu corpo como ferramenta, em algumas situações, para mostrar o que ele queria e ajudá-lo a pegar algo, sem coordenar com o olhar. Apontou para objetos com a mão inteira de forma coordenada com a vocalização, mas não fez uso espontâneo de gestos descritivos, convencionais, instrumentais e informacionais.

Durante todo o tempo, ele fez pouco contato visual para iniciar, regular ou finalizar uma interação social. Não fez contato visual quando chamado pelo nome por mim e pela mãe, e não conseguiu usar a orientação do meu olhar como uma pista para saber a que ela direcionava sua atenção, sem a necessidade de que lhe fosse apontado ou falado.

Ele direcionou expressões faciais para mim e para a mãe em alguns contextos, não sorriu em resposta ao meu sorriso, mas conseguiu demonstrar prazer em mais de uma atividade.

Em relação a dar objetos, Henrique o fez apenas com o propósito de pedir ajuda e não de compartilhar. Sobre mostrar objetos, ele não o fez durante a observação.

Henrique não chamou minha atenção e/ou da mãe para nenhum objeto de interesse que estava fora de seu alcance, e também não utilizou a triangulação do olhar (pessoa-objetopessoa) para requisitá-lo. De maneira geral, suas aberturas sociais foram restritas a seus interesses e demandas. 
Em relação às brincadeiras, ele brincou apropriadamente e funcionalmente com brinquedos variados (blocos e bolas, por exemplo), e fez pouco uso das miniaturas de objetos cotidianos. Fez brincadeiras espontâneas de imaginação, mas não utilizou os brinquedos como agentes independentes de ações.

Henrique apresentou interesse sensorial incomum pelas roda do avião e do carro. Foi notada a presença de maneirismos e interesse repetitivo em brincar com carros/caminhão, embora isso não o impedisse de realizar as outras atividades propostas. Não foram observados comportamentos de autoagressão, disruptivos, ou agressivos.

Ele apresentou apenas certa dificuldade em permanecer sentado nas atividades em que esse comportamento era esperado, sendo preciso o auxilio da mãe.

Pela escala, sua pontuação indicou diagnóstico de autismo, com grau moderado de sintomas relacionados ao TEA.

Quatro meses de atendimento depois, Henrique (seis anos e dez meses) já demonstrava maior abertura à minha presença, e frente às minhas solicitações de que ele pedisse quando quisesse determinado carro para brincar, ele passou não só a pedir espontaneamente em algumas situações, mas também a fazer outras perguntas para mim e até mesmo me incluir em alguns momentos de sua brincadeira. Ele passou a olhar mais ao dirigir sua fala a mim, independentemente de um pedido de ajuda.

Nesse curto tempo de atendimento, notamos também algumas dificuldades cognitivas e de coordenação motora de Henrique, quando comparado a crianças de sua idade (ele estava com quase sete anos neste momento). Percebemos que, embora ele gostasse muito da brincadeira com carrinhos e pistas, quando apresentada uma pista impressa em um papel, ele parecia não discriminar a imagem, e simplesmente passava o carrinho por cima do papel. Apenas quando fizemos um contorno físico com massinha é que ele reconheceu como uma pista. Além disso, fizemos algumas brincadeiras simples com quebra-cabeças de quatro peças com a imagem dos carros que ele mais gostava, e ele apresentou muita dificuldade em montar, pois não conseguia se guiar nem pela cor da imagem e nem pelas formas do encaixe. Ele não parecia reconhecer as letras de seu nome, e não conseguia acompanhar pequenas histórias, mesmo quando guiadas por imagens em livros.

Em conversa com os pais, eles também notaram tanto os progressos quanto as dificuldades de Henrique. A mãe chegou a comentar, na ocasião, que diferente da abordagem comportamental, com o qual o filho havia sendo tratado até então, nossa abordagem fez com que ela passasse a tratar o filho "de uma forma diferente, como uma criança mesmo, e isso está 
fazendo com que ele esteja mais aberto a aprender e ser mais flexível. E inclusive mais independente no autocuidado!".

Aos oito meses de atendimento com Henrique (sete anos), seu pai solicitou que eu fosse conversar e orientar com os avós paternos, com quem o filho ficava no período da manhã, antes de ir para a escola. Ele gostaria que eu fosse na residência dos avós, observasse Henrique lá, e fizesse algumas recomendações a eles. Combinamos e eu fui. A avó demonstrou ser firme com o neto quanto às obrigações: colocar o uniforme, arrumar os brinquedos e almoçar. Entretanto, Henrique demonstrava resistência em atender e entender comandos rotineiros, por talvez não entender a sequência das ações. Isso fez com que eu produzisse um quadro de rotina visual para a casa dos avós, com imagens sobre cada uma das atividades que ele faria ali até o momento de ir para a escola. A instrução que foi dada era de retirar com ele quando cada atividade chegasse ao fim, e de que Henrique fosse avisado, verbalmente e com certa antecedência, sobre a próxima ação, dando tempo para ele mesmo se organizar.

O retorno que tivemos foi positivo, no sentido de que tal orientação havia diminuído a resistência de Henrique para as tarefas cotidianas.

Neste período, por conta das dificuldades cognitivas e pedagógicas, acabei indo à escola algumas vezes para conversar com a professora e coordenadora, e preparei um material adaptado que ele usou naquele semestre.

Aos nove meses de atendimento, o contato visual dele estava ocorrendo com maior frequência, e ele tinha aprendido a chamar pelas pessoas com quem conversava usando vocativo, o que já auxiliava bem na interação, uma vez que o contato visual por vezes ainda falhava. As frases e palavras descontextualizadas e reproduzidas de memória a partir de desenhos passaram a ser ditas apenas quando Henrique se via frente a alguma tarefa ou brincadeira mais desafiadora, em que lhe faltavam ainda recursos para executar. Isto é, em momentos de muita ansiedade. Nessas ocasiões, pedia que ele dissesse que estava difícil, ou que não queria fazer, ao invés de reproduzir essas falas e, embora no começo fazer isso também fosse um desafio, aos poucos ele foi dominando o receio de dizer e de tentar fazer: ora dizia que não queria, ora pedia que eu guardasse a atividade, e ora simplesmente tentava, após alguma insistência minha. Em alguns momentos, ao tentar e conseguir fazer algo que até então era difícil, ele compartilhava sua alegria segurando meu rosto na altura do dele, olhando nos meus olhos por mais de 10 segundos, e em seguida fazendo carinho com a mão na minha bochecha.

Com essa abertura e confiança para tentar, Henrique começou a aceitar jogos e brincadeiras fora de seu principal tema de interesse (carros), e passou a conseguir apontar com 
o dedo indicador os jogos que queria, mostrando-me no armário. Em quase todas as sessões ele passou a pedir que eu lesse uma história, e nesses momentos ele olhava as imagens e o texto com atenção, e dava risada com as diferentes vozes que eu fazia para os personagens ou mesmo com algum fato narrado, demonstrando entender a situação apresentada.

Nós passamos também a fazer algumas histórias juntos: eu começava ou ele pedia que eu começasse a narrar a brincadeira dele, e aos poucos eu passava de narradora a escritora, junto com ele. Podia dar ideias, fazer sugestões, e ele ficava aguardando por esses momentos. A brincadeira imaginativa passou a ser uma atividade conjunta.

Ele passou a pedir que eu não colocasse mais a massinha para fazer o contorno das pistas, e seguia as linhas sem apoio, e também começou a montar os quebra-cabeças se guiando pela forma do encaixe. Isto é, pela repetição, sempre acompanhada, ele mostrou avanço cognitivo-motor nas atividades de brincadeira.

Ao final do atendimento clínico, após um ano e meio, Henrique já dirigia sua fala a mim, integrando-a ao contato visual; este tornava-se cada vez mais frequente e com uma duração maior; as falas de repetições de desenhos animados quase não aconteciam mais; ele estava mais disponível para novas brincadeiras, jogos e atividades; conseguia demonstrar prazer na interação comigo; mostrava objetos com o objetivo de compartilhar; estava conseguindo dizer "não" quando não queria algo, ao invés de ignorar ou se afastar; me aguardava espontaneamente para começarmos a brincadeira juntos; a brincadeira imaginativa ganhou novos personagens que não só os carros, bem como novas ações e cenas, como tomar banho, dormir, ir para escola, andar de trem, assistir a uma corrida; e ele estava conseguindo usar um objeto para representar outro sem apresentação prévia feita por mim. Ao final das sessões, ele já conseguia ir embora sem querer levar nenhum brinquedo para casa e sem ter que deixar nenhum brinquedo na sala de espera.

Tais mudanças foram notadas tanto pelos pais quanto na escola. A professora de Henrique relatou que ele estava conseguindo interagir com pessoas com quem tinha pouco contato, que tinha feito amizade com uma criança mais velha, que estava obedecendo a comandos simples de rotina, batento palma apenas quando muito feliz, e que estava até pedindo por mais atividades!

Na segunda avaliação da ADOS, realizada a pedido nosso, Henrique estava com sete anos e dez meses. A quantidade de sintomas relacionada ao autismo continuou sendo moderada, mas reduziu em 5 pontos, saindo da terceira parte (de três) superior da faixa de moderado e chegando à segunda (de três). Ele apresentou melhora em relação a apontar, contato visual, 
integração do contato visual e outros comportamentos durante as aberturas sociais, compartilhamento de prazer na interação, mostração de objetos para compartilhar, uso estereotipado de frases e palavras.

No ano seguinte, por conta da mudança de professora e acompanhante terapêutica, além de alterações na medicação (inicou e parou com Risperidona), Henrique teve alguns picos de ansiedade, falta de atenção e agitação motora. Os pais solicitaram que ao invés das sessões, Henrique fosse acompanhado por mim na escola, uma vez na semana, para orientar a instituição. O vínculo comigo permaneceu, ele progrediu pedagogicamente em alguns aspectos, mas ao final do semestre (Henrique com oito anos e quatro meses) estava clara a necessidade de uma escola mais adequada para a sua demanda, bem como a retomada do trabalho terapêutico.

Henrique mudou de escola, mas ficou sem terapia por questões familiares.

Vamos agora para as cenas, que ilustram e mostram um pouco como todas essas mudanças foram possíveis.

\subsubsection{Cenas}

Conviver com Henrique é sensibilizar-se em diferentes aspectos pela "parte que lhe toca" (ao Henrique) na relação. Daí, e só daí, é possível derivar (sem necessariamente tomarmos consciência disso) o rumo a tomar nas sessões de sua terapia.

Durante todo seu atendimento, nos diferentes contextos em que este se deu, e sobretudo nos primeiros encontros com ele, tínhamos a sensação de que sua resposta ao que solicitávamos parecia ter menos a ver com um isolamento caracterizado como das pessoas com autismo, do que com uma espécie de problema na decodificação do que lhe falávamos e de organização de um enunciado, de uma fala que pudesse dizer o que se passava com ele. Uma dificuldade no plano cognitivo, possivelmente, provocava um conjunto de reações que nos levava a ter a impressão de que ele tinha uma conduta de desligamento da situação, ou que ele agia por comportamentos aparentemente erráticos. Isso, no entanto, vinha associado ao não olhar para o interlocutor, o que mais uma vez o carregava para o diagnóstico de TEA.

Como se poderá notar pelas cenas que se seguem, selecionadas para o presente relato antes mesmo da escritura desta abertura analítica, nosso olhar e nossa escuta dirigiam-se para outra direção que não as dos traços de autismo a serem "tratados". Recorrentemente éramos 
conduzidos a pensar em como conversar com esse menino silente mas fortemente presente ao que acontecia ali.

Com o tempo o recurso do olhar dele e de seu sorriso (uma marca característica para dizer de seu gosto/prazer com o que propúnhamos e com o modo como o provocávamos a brincar juntos) começaram a ser seu forte para dizer a respeito de o que movia e sobre o que poderia estar sentindo/pensando.

Já se anuncia, nisto que ora pontuamos, a dimensão afetivo-expressiva que constituiu essa relação terapêutica. De tal forma que passo a falar em primeira pessoa do singular, pela singularidade dessa relação.

Fica bastante evidente que eu acompanhava o que ele fazia, para onde se dirigia (sobretudo nas primeiras sessões em que eu parecia precisar com urgência conhecê-lo, saber de suas reações para poder lidar com ele). A incógnita vinha de eu notar que ele me ouvia sim, mas só respondia quando the parecia muito claro que eu dizia algo meio "absurdo" para um adulto dizer. Estávamos na verdade, eu e ele, ao que tudo indica, querendo descolar os pés do chão para que as palavras voassem. Em verdade, quando ele sorria para mim, de repente, enquanto eu fazia uma fala imaginativa como comer macarrão de massinha, mais parecia rir generosamente de mim. Ao mesmo tempo, alçada a dupla em ação, instaurava-se uma comunicação que me potencializava a entender e muitas vezes a traduzir para ele o que eu estava entendendo, mas como se fosse ele dizendo para mim. Com frequência máxima, nessas horas, ele repetia a frase como se ele também tomasse posse de toda a estrutura da língua e possibilidade da fala, apesar de a construção da frase ser minha, bem como apesar de sua dificuldade de pronúncia.

Uma incrível intimidade e compartilhamento de sentidos foi se construindo, então, e permitindo que a comunicação fosse atipicamente falada, mas genuinamente discursiva. Eé aí que a última cena relatada aqui é uma explosão de expressividade, tradução de sentidos, como se a "cena interna" de um intenso movimento afetivo encontrasse inclusive na palavra, mas sobretudo nas expressões e nos corpos um insustentável sofrimento do (de) ser.

Leia-se!

Cena 1

Uma situação exemplar teve início com os carros e, depois, expandiu-se para os personagens do desenho Peppa Pig, que foi por um curto tempo objeto de interesse do Henrique em alternância com os carros. Fiz a proposta de brincar com a casinha e fazer dela o cenário dos personagens, e ele aceitou. Depois de, várias vezes, colocar os personagens para dormir e acordá-los, eu sugeri que eles fossem comer. Fiz de massinha um macarrão, e perguntei para o Henrique se ele gostava. Ele não me 
respondeu. Perguntei novamente, mas agora dando alternativa de resposta e ele continuou sem me responder. Então, eu comentei como uma fala minha: "eu gosto muito de comer macarrão!". Neste momento, Henrique olhou para mim, sorriu e repetiu a frase (posteriormente, conversando com a mãe, ela confirmou a preferência do alimento pelo Henrique). (Anotações pessoais, três meses de atendimento, Henrique com seis anos e nove meses)

Nesta cena, no limiar do brinquedo e da realidade, Henrique se dispõe a expressar sinal de sua presença na situação quando eu falo da minha imaginação porque implica que vai comer algo que ele gosta. Ganha a imaginação e ele dá esse sensível sinal de presença com um sorriso.

Depois, repete a frase, confirmando alguma coisa que a mãe relata, posteriormente, como sendo uma preferência real em sua vida cotidiana. Sem nunca se distinguirem, os atos de imaginar e "realizar" mostram-se no âmbito do sentido para ele.

\section{Cena 2}

(...) Ainda sobre como Henrique brinca com os carros: notei que ele muitas vezes bate um no outro, ou joga-os no chão, e tal brincadeira, embora possa supor imaginação, é apenas uma suposição, uma vez que ele não verbaliza o que está acontecendo. Em dado momento, comecei a fazer as vozes dos carros, como se eles estivessem pensando em voz alta, ou mesmo conversando entre si. Henrique ficou bastante espantado quando fiz isso. Ficou olhando fixamente para mim, como se não estivesse entendendo minha fala. Depois, quando entendeu, passou a repetir algumas como "Cuidado! Se segura!" quando os carros vão cair de um outro brinquedo, ou "Ai! Ai! Ai!" quando um carro bate no outro, ou algum carro cai. (Anotações pessoais, quatro meses de atendimento, Henrique com seis anos e dez meses)

\section{Aqui fica claro como a minha atenção e brincadeira imaginativa funcionam como} preceptoras de alguma reação de interação da parte de Henrique, e novos sentidos parecem se constituir no brincar.

\section{Cena 3}

Henrique chegou bem animado! Ele viu o filme Aviões nas férias e está brincando bastante de avião e falando diálogos do filme. Hoje, quando ele chegou, eu contei para ele uma novidade: ele teria para brincar algumas miniaturas do filme! Isso porque na sessão anterior ele encontrou o avião Dusty, queria brincar com mais aviões e não tinha, e aí eu improvisei com ele colando adesivos do filme em um papel azul, recortando em forma de nuvem e pendurando um barbante nas nuvens para simular o vôo.

(...) Passado um tempo, Henrique começou a olhar para a sala como se estivesse procurando alguma coisa. Perguntei o que era e ele não respondeu. Dirigiu-se até o armário, na parte de cima, e ficou falando "avião, avião". Eu olhei, não encontrei nada de avião ali, peguei uma cadeira e pedi que ele subisse para ver e pegar o que queria, já que eu não estava entendendo. Ele subiu, olhou, olhou e também não encontrou. Então, virou-se para mim e começou a dizer "avião, avião", com lágrima nos olhos por eu não o estar entendendo. Foi então que eu lembrei dos aviões da semana passada que havíamos feito juntos. Falei para ele "Henrique, fica calmo, eu acho que entendi o que você quer. Você quer os aviões que fizemos juntos na semana passada? Eu vou buscar!" e ele repetiu "Você quer os aviões que fizemos juntos na semana passada?". 
Fui buscar para ele, e quando ele os viu, ficou radiante! Brincou um pouco com muita alegria.

Logo voltou-se para os de plástico mesmo, os novos, e começou a simular que eles estavam voando. Pela primeira vez o Henrique pegou a pista-caixa que eu havia feito para ele na segunda sessão de terapia, e usou a pista como uma pista para os aviões decolarem. E, pela primeira vez também, ele seguiu com os aviões o contorno da pista; nenhum avião passou pela grama ${ }^{30}$. (Anotações pessoais, seis meses de atendimento, Henrique com sete anos)

Temos inicialmente uma atenção de minha parte ao modo como Henrique se apresenta para aquela sessão (animado) e apresenta seus interesses (falando diálogos do filme).

Em seguida, pode-se observar que minha percepção instauradora de sentidos às falas dele, também, instrumentaram novas brincadeiras a partir de seus interesses para prosseguir com ações significativas.

Tive a confirmação de compreensão de Henrique, por repetir minha fala na mesma ordem de produção de sujeitos, objetos, ações, e também, pela demonstração empírica do entendimento: sua alegria. Nisso tudo, o fio da memória de uma sessão à outra, se garante...

\section{Cena 4}

(...) Mostrei para o Henrique o quebra-cabeças que tinha feito, de quatro peças, e sugeri que o montássemos. Ele não deu atenção. Eu disse que formava a imagem do McQueen, e ele também não olhou. Montei uma vez o quebra-cabeça e peguei o carrinho do McQueen para que ele conseguisse entender que tratava-se da mesma imagem. Assim que eu peguei o carrinho, Henrique estendeu a mão até a minha e tentou tirá-la para pegar o carro. Eu segurei, ele tentou novamente. Então eu disse "Henrique, se você quiser o carrinho, você precisa pedir para mim. Você pode dizer 'Me empresta, Luisa?'”. Ele tentou dizer isso, mas se atrapalhou um pouco e falou "Me embora, por favor, Luisa?". Eu repeti para ele que o verbo correto era "empresta". Ele repetiu corretamente, e eu passei o carrinho para ele.

Depois disso, e tendo ele visto o carro e a imagem do carro montada no quebra-cabeça, eu montei uma metade e deixei as 2 outras partes apenas indicadas onde era para colocar, e chamei a atenção do Henrique, novamente, para o jogo. Dessa vez ele olhou, encaixou facilmente a peça da parte superior, cujo encaixe era redondo, e quando foi encaixar a parte inferior, que tinha 2 triângulos de tamanhos diferentes, ficou um tempo tentando encaixar o menor no maior. Chamei sua atenção para o fato de que a imagem do carro ficaria muito estranha se fosse daquele jeito que ele estava tentando (veja, mostrei para ele a figura, o conteúdo, e não a forma), e ele não deu ouvidos. Perguntei para ele onde ficava a roda do carro, mostrei onde estava a roda da frente na imagem, e disse que a outra roda deveria ficar ao lado. Henrique continuou insistindo na forma. Para que não perdesse o interesse, disse para ele que precisava girar a peça, girei para ele, e ele conseguiu encaixar.

Conversando com a mãe de Henrique, ao final da sessão, ela confirmou que ele não consegue mesmo se guiar pela figura, e que havia percebido isso no dia anterior, quando viu Henrique tentar montar um quebra-cabeça no iPad. Disse para ela que era interessante notar que ele se guia pela forma, e não pelo conteúdo, e que essa característica é notável também na fala. Quando o Henrique foi pedir para eu

\footnotetext{
${ }^{30}$ Normalmente, ao brincar com pistas de papel, Henrique fazia os carros passarem por cima das partes que não eram da pista, como se elas não existissem. Ele não seguia o percurso. Nas sessões anteriores a esta, fiz para ele bordas de massinha nas pistas de papel, e essa foi a única maneira do carro seguir o caminho da pista: com um contorno concreto.
} 
emprestar para ele, ele usou o verbo errado, mas com a mesma entonação, e acrescentou um "por favor", mostrando que identificava a frase como um pedido. Entretanto, o verbo estava errado, e, no caso, o verbo seria o conteúdo.

Dizer isso para a mãe fez com que ela percebesse que o Henrique não deve entender muitas coisas que são ditas para ele. E fez com que eu conseguisse explicar para ela que muitas vezes ele chora sem parar porque ele não entende o sentido do que estamos dizendo para ele, e também não consegue se fazer entender (vide quando ele queria os aviões de papel e não conseguia me explicar para que eu pudesse pegar para ele). (Anotações pessoais, oito meses de atendimento, Henrique com sete anos e dois meses)

Aqui eu exploro os limites possíveis da compreensão de Henrique. Confiando nele e em mim, provoco um pedido por meio de palavras, e dou todas as palavras para que ele o formule. Nesse momento eu pareço antecipar a competência dele para esse pedido-gesto-enunciado. E veja que a correção não se importou com a questão do erro ou acerto, mas contemplou o acerto maior que foi à ideia de um pedido que ele deslocou tão sabiamente para a expressão "por favor".

Eu antecipo na fala o que pode ser feito, o que pode acontecer, e o demonstro em meu próprio gesto. Mas o mais importante aqui é que minha ajuda entra quando me preocupei com não ultrapassar os limites de seu interesse.

Os outros parceiros de vida de Henrique também podem esclarecer e/ou confirmar sobre os limites e alcances da compreensão dele. E eu não me poupei de dizer à mãe, no exterior da sessão, o modo como Henrique apreende a realidade. Extensão da compreensão clínica às outras situações de comunicação, favorecendo as possibilidades dele de se relacionar.

Ao conversar com a mãe de Henrique, ocupei o lugar de terapeuta-tradutora ao dizer os efeitos dessa atenção discriminativa sobre outros atores nas cenas vividas no cotidiano e com outros parceiros.

Por esse trecho vemos que eu coloquei a palavra e os enunciados que deram a direção do fazer de Henrique; mas não só para ele...

\section{Cena 5}

Quando faltava 20 minutos para terminar a sessão, começou um barulho muito alto e forte vindo do vizinho. Henrique quis sair da sala, e foi para porta dizendo "Mamãe! Mamãe!". Eu abri a porta para ele, e chegando na sala de espera ele quis ir embora. Sua mãe disse que as coisas não funcionavam assim, quando ele queria, que ele tinha que perguntar para mim se já havia terminado a sessão. Eu disse que não, mas que ele estava incomodado com o barulho.

Nisso, Henrique abriu a porta do consultório e saímos. Vimos um pedreiro na porta da frente, e eu solicitei que aguardasse 20 minutos para que voltasse a fazer barulho e ele disse que tudo bem.

Entrei com o Henrique na sala de espera e disse que tinha combinado com o moço que ele não iria fazer barulho, e que nós poderíamos voltar para a sessão. Henrique foi para a sala na hora. 
Ao entrar, se jogou nas almofadas e montou um tipo de uma cama. Eu disse que ele estava cansado, porque tinha acordado cedo, e também por conta do barulho, e que então eu iria contar uma história para ele. Peguei um livro que não era de personagens conhecidos por ele. Comecei a ler, e então ele foi até mim, fechou o livro e disse "História da Peppa!". Foi muito bacana ver que ele quis ouvir a história e ainda pediu, escolhendo a que queria. Li duas vezes para ele, lendo todo o texto, e ele ouviu atentamente. (Anotações pessoais, oito meses de atendimento, Henrique com sete anos e dois meses)

No início desta cena, quando Henrique vai ao encontro da mãe, o estado afetivo do menino passa desapercebido por ela, mas não passa desapercebido por mim, que verbalizo algo para o entendimento da mãe, inclusive (Henrique estava incomodado com o barulho).

Ele acompanhou tudo (desde minha fala com ele e sua mãe, até com o pedreiro). Parecíamos ter resolvido uma fortíssima tensão, ao favorecer um entendimento sobre o que estava acontecendo ao redor do espaço terapêutico. Esse redor existe, e não podemos negá-lo. Resolvida a tensão, sem qualquer repreensão como a da mãe, ele retorna para sala. ${ }^{31}$

Ao final da sessão, o meu relato sobre minha percepção a respeito do que estava acontecendo com ele (estar cansado por ter acordado cedo e por conta do barulho), após ele deitar nas almofadas, bem como a sugestão de contar-lhe uma história indica que há uma interlocução em ato, calcada na troca de atenções e cuidados. Inclusive, da parte dele para comigo, isso acontece. Observa-se a tolerância dele à escolha arbitrária desta terapeuta sobre o conto que iríamos ler; deu um jeito de a leitura vencer rapidamente as páginas para, então, solicitar o que talvez quisesse desde o início, a "história da Peppa"!

Cena 6

Assim que Henrique entrou na sala, logo pegou dois personagens do desenho
Backyardigans e tentou colocá-los dentro do carro de bombeiros. Como não
conseguiu, pediu ajuda para mim, falando a frase inteira: "Luisa, me ajuda a colocar
os Backyardigans no carro de bombeiros?".
Nessa brincadeira de o caminhão andar com dois personagens, ele dizia "Me espera!
Me espera!". Rapidamente eu peguei o Tyrone e fiz que era ele quem estava falando,
correndo atrás do caminhão. Henrique deu risada, demonstrando ter gostado da minha
ideia. Parece que ele se diverte comigo quando transponho os limites entre imaginação
e realidade nas brincadeiras... Depois, pegou o Tyrone na mão, olhou um pouco e deu
um abraço.
De volta ao carro de bombeiros, perguntei para onde eles estavam indo. Henrique
disse que iam para casa, e então eu peguei a casinha. Mas, imediatamente ele disse
"Guarda! Guarda!". E eu guardei.
O caminhão continuou dando voltas. Eu perguntei, novamente, para onde eles
estavam indo, e Henrique respondeu dessa vez que eles estavam indo para a escola.
Aí eu comentei "Meu Deus! Eles estão indo de caminhão de bombeiros para a

\footnotetext{
${ }^{31}$ Alguém poderia, a rigor, considerar essa situação como não sendo propriamente uma brincadeira, mas o que importa aqui é chamar a atenção para a dimensão da experiência afetiva desse momento: continência e sintonia entre os parceiros para dar um caráter construtivo ao que acontecia "ao redor do espaço terapêutico" (a sala de atendimento).
} 
escola!", e Henrique riu, demonstrando ter entendido a peculiaridade do que estava criando. Peguei a escola de brinquedo, montei, e ele colocou apenas o Tyrone lá. Depois, com o caminhão, foi até a estante de brinquedos e pegou um brinquedo de encaixe com chaves para abrir as portinhas. Notei que ele não entendia intuitivamente que a cor da chave correspondia à porta que ela abria. Expliquei duas vezes mostrando e ele entendeu. Após abrir e fechar algumas vezes, ele tirou todas as peças (com a minha ajuda), e organizou toda a turma do Backyardigans em roda, em pé, e fez como se fosse uma atividade da escola.

Essa brincadeira terminou, ele foi brincar com os carros, e quando estava perto da hora de ele ir embora, eu comecei a desmontar aquela cena que fizemos, guardando os personagens, sem avisar para ele. Assim que ele me viu retirando as personagens ele disse "Não, não!" e as recolocou. Em seguida, tivemos o seguinte diálogo:

- Por quê ta chorando?

- Você não está chorando, Henrique.

- Ihhhh. Ele não quer ir embora. (referindo-se a si mesmo, demonstrando que eu estava arrumando pois já era hora de ir embora). (Anotações pessoais, um ano de atendimento, Henrique com sete anos e seis meses)

No começo da cena eu pareço buscar o limite entre as demandas dele e as de uma personagem fictícia. E, assim como na cena do macarrão de massinha, Henrique ri. Há aí um jogo entre a brincadeira imaginativa e a realidade, entre Tyrone ser uma personagem ou ele ser o Tyrone...

Ao final, quando ele pergunta "Por quê ta chorando?", podemos ver que o "chorando", aqui, tem sentidos múltiplos, condensados, deslocados, cabendo a mim tentar separar os sentidos para devolver a comunicação ao Henrique. Essa dificuldade linguística de distinguir o sujeito da ação e seu objeto parece fazer uma boa composição com a habilidade dele de dizer algo que lhe faça sentido.

Cena 7

$\mathrm{Na}$ brincadeira com os carros, Henrique jogou longe o McQueen e ficou olhando para mim. Como eu não entendi o que ele queria que eu fizesse, não fiz nada. E aí, olhando para mim, ele disse "Ai! Ai!", como eu costumo fazer. Eu fiz, ele sorriu e então levou o Doc até o McQueen dizendo "Eu vou te ajudar!". Eu fiz a voz do McQueen agradecendo e contando o que havia ocorrido, e ele adorou, deu bastante risada. Ele continuou fazendo o Doc e disse "Vamos trocar os pneus!". Eu peguei um martelo de brinquedo, dei para ele, e ele fez de conta que estava trocando.

Depois, eu sugeri que fizéssemos uma corrida no gelo, usando as peças de um outro jogo, e ele imediatamente colocou o McQueen e o carro rosa em cima dos cubos de gelo, e novamente fez o Doc dizer que iria ajudar, pois eu tinha feito o McQueen dizendo que a água estava muito fria e ele iria congelar!

Em sequência, Henrique começou a dizer “Qué (sic) uma pizza! Uma pizza!”. Mas eu não tinha certeza se era isso mesmo, por conta da dicção dele. Então eu perguntei "Você quer pizza, Henrique, de comer?" e ele só repetia "Uma pizza! Uma pizza!". Pedi que ele me mostrasse o que era, ele foi até o armário onde ficam as comidinhas de plástico e pegou a pizza de brinquedo!

Fizemos os carros comerem e tomarem suco. Coloquei para ele o fogão e as panelas e ele super entendeu: colocou a pizza na panela e a panela no fogão.

Depois, ele voltou com os carros para a pista de corrida. Um deles corria, e na vez do McQueen, Henrique dizia "Não qué (sic) correr, não qué (sic) corrida.". Perguntei o 
motivo do McQueen não querer correr, mas ele não respondeu de imediato. Passado um tempo ele fez o McQueen ir na pista, escorregar e o Doc ir ajudá-lo.

Quando chegou a hora de finalizarmos nossa brincadeira, eu o avisei e ele colocou os carros na casinha dizendo "Vai dormir! Vai dormir!". (Anotações pessoais, um ano de atendimento, Henrique com sete anos e seis meses)

No início da descrição, eu digo "como não entendi o que ele queria" e, neste caso, entender é entender os lugares na brincadeira. Henrique se apropriou completamente da ideia da brincadeira e a propôs, como pudemos ver na sequência, com o "Ai!Ai!".

Ainda neste começo, fica nítido como ele se diverte quando entende e é entendido na brincadeira... E tanto no primeiro como no segundo parágrafo da cena, podemos notar que ações humanas de solidariedade ("eu vou te ajudar") preenchem as trocas no brincar de Henrique.

No penúltimo parágrafo, na falta das palavras e enunciado, os gestos de Henrique fazem o brincar absolutamente compreensível para ele e para mim. E no último parágrafo, os carros dormem, a brincadeira pode terminar e os parceiros mais uma vez se entendem e complementam sentidos. Como o ato de imaginar ajuda a interromper um brincar tão rico de recursos de ambos os lados!

\section{Cena 8: Quando falta o sentido da palavra}

Nas duas primeiras sessões no consultório novo, quem foi com Henrique ao banheiro foi o pai. Como o pai não estava lá quando saímos da sala, eu fiquei parada na porta. Ele perguntou sobre o pai, eu disse que ele tinha ido comprar umas coisas e já voltava. Henrique saiu do banheiro na hora e começou a procurá-lo. Voltei com ele ao banheiro para que fizesse o xixi, e depois ele saiu procurando o pai.

Bem, ao não encontrar o pai, mesmo comigo dizendo onde o pai tinha ido e que voltaria para buscá-lo, Henrique ficou completamente angustiado e desorganizado. Ele começou a chorar alto e andar de um lado para o outro freneticamente. Eu o abracei, disse que o pai voltaria, que o pai o amava muito, e pedi para que ele se acalmasse para nós esperarmos. Ele se acalmou por nem 1 minuto e voltou a se desorganizar. Tive a ideia, então, de ligarmos para o pai, para o Henrique falar com ele e ficar mais tranquilo. Fizemos isso, deixei no viva-voz e o pai disse para o Henrique não chorar, que ele ia voltar logo. Novamente Henrique se acalmou por nem um minuto, e voltou a andar e ir para a janela olhar pra ver se via o pai, e chorar desesperadamente. Sentei com ele no sofá (que dá para a janela), abracei-o, disse que ele não precisava se preocupar porque o pai voltaria, disse que estava tudo bem, e que ele iria conseguir esperar. Ele olhava para mim chorando e me abraçava de volta, depois se acalmava, perguntava se o pai iria voltar, ficava por mais 1 minuto calmo e então tudo recomeçava. Depois disso, sugeri que fizéssemos uma colagem com os adesivos para entregarmos ao pai quando ele chegasse. Henrique fez, colou em 2 folhas, e, enquanto fazia isso, conseguia não chorar. Ao terminar, voltou a chorar. Eu o abracei novamente, segurei ele no colo, peguei um livro da Peppa Pig e fui com ele para a sala de espera, esperarmos juntos, lendo, o pai chegar. Henrique conseguiu ouvir a história com calma, e na metade dela o pai chegou. Ele ficou super feliz, deu pulos de alegria, e voltou para a sala para finalizarmos a sessão. Quanto sofrimento. (Anotações pessoais, um ano e seis meses de atendimento, Henrique com oito anos) 
Temos, aqui, a tentativa de reorganização afetiva em atos... sem qualquer interpretação. Até porque, o entendimento mais solidário eu já o tinha para mim: havia ali muito sofrimento e muita vontade de superá-lo com a ajuda de minha parceria...

O que vale nesta cena é a contenção carinhosa que faço e as possibilidades que tenho de seguir Henrique por onde quer que fosse sua desorganização.

\subsubsection{Thiago: "Eles passarão... eu passarinho!"32}

Todo o atendimento de Thiago foi realizado com a AID. Na ocasião, nós já tínhamos a certificação da escala ADOS, e esta foi aplicada no início e no final do trabalho clínico com ele. Thiago foi atendido por mim no consultório durante oito meses, e após esse período ele foi acompanhado por mim na escola por mais um ano, e, paralelamente a este trabalho, outra pessoa de minha equipe seguiu com ele o atendimento clínico.

\subsubsection{Breve histórico}

Conforme o relato dos pais, antes mesmo de Thiago ter completado um ano, já imaginavam que algo pudesse não seguir o curso esperado para o seu desenvolvimento uma vez que o filho apresentava muita dificuldade para dormir e era muito inquieto. Quando Thiago completou um ano, eles notaram que diferentemente, também, das demais crianças, ele não batia palmas e ainda não falava. Apesar desse estranhamento, na época, por não terem contato com outras crianças, acharam que seria algo que se desenvolveria com o tempo.

Com um ano e oito meses Thiago entrou na escola, e após os seis primeiros meses de aula, em uma reunião pedagógica da família com a escola, a coordenadora relatou que o menino não conseguia participar das atividades escolares, não havia nenhum material gráfico dele para apresentar aos pais, que ele não se aproximava e parecia não querer se aproximar das demais crianças da turma, e não respondia quando chamado pelo nome. Na ocasião, ela sugeriu que a família procurasse ajuda psicológica e que Thiago fizesse um exame auditivo.

Nos dias que sucederam essa reunião, os pais fizeram buscas na internet colocando as características do filho relatadas pela escola, e chegaram ao diagnóstico de autismo. Os textos encontrados pareciam descrever, de fato, Thiago. Nessas mesmas buscas, eles encontraram uma

${ }^{32}$ (Quintana, 2005) 
instituição que atendia crianças com deficiências múltiplas, próxima à residência deles, e levaram Thiago lá para que fizesse um trabalho com uma terapeuta ocupacional.

Thiago estava com dois anos e quatro meses quando deu início a este primeiro tratamento. A terapeuta trabalhava com o método Son-Rise, e logo após os primeiros atendimentos, questionou o possível diagnóstico do menino, e sugeriu que os pais o levassem a um neurologista.

Ela nos relatou ficar esgotada com alguns comportamentos que o filho tinha, como: ordenar objetos respeitando critérios muito curiosos, como, por exemplo, enfileirar produtos de limpeza, caixas de leite e suco com os códigos de barra voltados para cima e alinhados; aceitar apenas mamadeiras de determinada marca e cor para ingerir líquidos; e apresentar uma reação oposta em relação aos seus brinquedos, de espalhá-los pela casa e não brincar com nenhum. Ter medos e pavores singulares, como pavor da queda da água do chuveiro no corpo, e o incômodo absoluto ao ouvir sons agudos. Além da seletividade alimentar e dificuldade em permanecer sentado.

Quando Thiago estava com 2 anos e 8 meses, a família o levou a um neurologista infantil que diagnosticou o menino com TEA, e recomentou a terapia comportamental como tratamento, e fonoaudiologia.

Conforme o relato da mãe, Thiago parou com as sessões de terapia ocupacional por questões financeiras e fez 7 meses de terapia psicológica na abordagem comportamental. A mãe interrompeu o tratamento por conta de seu filho chorar muito durante as sessões e ficar agressivo, jogando coisas no chão ao ser contrariado e batendo nela.

Na mesma época a mãe relatou que iniciou com ele um método de comunicação alternativa $\left(\mathrm{PECS}^{33}\right)$, confeccionado por ela mesma, e ele aprendeu a falar algumas palavras e formar pequenas frases que, segundo ela, eram em sua maioria ecolálicas.

Thiago frequentou, então, um Centro de Apoio Psicossocial Infantil (CAPSi) próximo à sua residência, em que teve acompanhamento de uma psiquiatra, mas a família acabou não prosseguindo com o atendimento, pois, na época, conforme a mãe relata, o filho ainda não dormia a noite inteira, tinha muita diarréria, seletividade alimentar, e quando ela o levava ao pediatra, ele não dava respaldo a ela para que algo mudasse na qualidade de vida deles. Então, ela acabou retomando o contato de uma médica nutróloga que a terapeuta ocupacional havia

\footnotetext{
${ }^{33}$ Picture Exchange Comunication System (PECS) é o nome de um método de comunicação alternativa norte americano, criado em 1990 por Andrew S. Bondy e Lori Frost, em que a pessoa com dificuldade de se comunicar verbalmente aprende a se comunicar mostrando imagens, ao invés da comunicação verbal. < http://www.pecs-brazil.com/pecs.php>
} 
passado para ela, e iniciou o tratamento biomédico (dieta sem glúten e caseína, quelação de metais pesados, entre outros). Por indicação dessa médica, deu inicio ao tratamento psicológico de Thiago com a Equipe Novo Olhar, e parou de frequentar o CAPSi.

Conhecemos Thiago com 4 anos e 4 meses. Um menino magro, alto, cabelos e olhos castanhos. Tímido, de fraldas, carregando um travesseiro pequeno com uma fronha bem sujinha, apelidado de "travesseiro do anjo", pois na fronha havia uma oração ao anjo da guarda. Segundo a mãe, tudo poderia faltar, menos o travesseiro! E assim, conhecemos o menino e seu objeto de apego. Os dois vinham sempre para a sessão, muito embora o travesseiro ficasse sempre no sofá, e o menino por toda a sala.

Thiago foi atendido por mim no consultório durante oito meses e, no ano seguinte, por dez meses na escola. Neste tempo em que contou com nosso atendimento, ele trocou de escola uma vez, e teve apenas a nossa intervenção terapêutica.

Quando eu passei a acompanhá-lo na escola, outra pessoa da Equipe Novo Olhar deu continuidade ao atendimento de Thiago no consultório. Fizemos essa escolha, de eu trabalhar com ele na escola, por conta do vínculo positivo que tínhamos estabelecido, e também pelo fato de a escola já ter tido contato comigo devido ao trabalho com outros alunos.

Thiago concluiu o ensino infantil naquela escola, e no ano seguinte mudou para uma escola maior, que tinha ensino fundamental, e não permitia acompanhamento terapêutico. As sessões de psicoterapia foram interrompidas por questões financeiras.

Thiago segue nesta mesma escola até o momento e continua, também, com a intervenção biomédica. Nós temos notícia dele por vídeos e fotos que sua mãe nos envia, e também pelo seu próprio canal no YouTube!

\subsubsection{Sobre o desenvolvimento de Thiago durante o atendimento}

Thiago foi avaliado pela ADOS, aos quatro anos e quatro meses, logo na primeira sessão. Naquele momento, ele usou majoritariamente palavras únicas e aproximações de palavras para se comunicar, e dirigiu-se pouquíssimas vezes às pessoas que estavam no mesmo ambiente que ele, apenas dizendo o nome dos objetos de seu interesse. Não apontou e nem fez uso de gestos, mas direcionou expressões faciais e respondeu ao sorriso de outras pessoas. $\mathrm{O}$ contato visual foi breve e ele não respondeu ao chamado pelo nome.

Na ocasião ele mostrou objetos de forma espontânea e fazendo contato visual, mas não chegou a dar objetos sem o intuito de pedir ajuda. Thiago quase não apresentou momentos de 
atenção compartilhada, fosse para chamar a atenção de alguém ou para responder a um momento proporcionado por alguém.

Ele brincou de forma apropriada com brinquedos de causa e efeito, mas não fez uso funcional de brinquedos que representavam objetos do cotidiano e também não utilizou brinquedos como representações de outros objetos.

Não apresentou estereotipias de fala ou outros comportamentos estereotipados, mas demonstrou intenso interesse por livros, criando pequenos rituais na própria ocasião da avaliação.

Thiago demonstrou algumas sensibilidades sensoriais quanto a sons e contato com massinha de modelar, e assustou-se com com o voar da bexiga ao soltar o ar.

Teve dificuldade em permanecer sentado nas atividades em que esse comportamento era esperado e apresentou comportamento disruptivo (jogar objetos e dar cabeçadas nas pessoas) em mais de uma ocasião durante a avaliação.

Conforme a escala, sua pontuação indicou diagnóstico de autismo, com grau moderado de sintomas relacionados ao TEA.

Após 3 meses de atendimento e orientação aos pais, Thiago (quatro anos e sete meses) ainda mantinha alguns rituais de organização da sessão: elegia os livros de uma coleção de histórias da Disney, enfileirava-os, alinhava-os, lia o título, e aí permitia uma interação comigo. A princípio eu só podia acompanhá-lo nesse processo, mas depois passou a pedir que eu contasse as histórias dos livros, e neste momento ele respondia ao que eu perguntava ou repetia minha pergunta. Seu contato visual estava com uma frequência maior, embora a duração ainda fosse curta, e ele passou a apontar para o título dos livros e imagens. Ele estava começando a dizer "não"/"não qué" quando não queria algo que eu propunha, ao invés de tentar me dar cabeçadas ou rosnar demonstrando insatisfação. Começamos a notar momentos de ecolalia imediata e construções de frase em terceira pessoa.

Essa brincadeira teve um desdobramento importante: permitiu que eu introduzisse os personagens de briquedo das histórias. Mais um mês, e Thiago estava brincando com miniaturas, representando como no livro, imitando as cenas ilustradas.

Com 6 meses de atendimento, Thiago (quatro anos e dez meses) havia expandido seu leque de brincadeiras. Ele passou brincar também com jogos de personagens que gostava, montar quebra-cabeças simples, manusear brinquedos de encaixe e construção. Os livros ainda eram os favoritos, mas agora ele já estava disponível para conhecer novas histórias e personagens. Thiago já formava frases curtas e conseguia incluir vocativos ao fazer pedidos, 
passou a cantar nas sessões, e em alguns poucos momentos estava começando a pedir ajuda quando não conseguia pegar ou fazer algo.

Ele acabou descobrindo, nesta época, um livro chamado Vai, você consegue! ${ }^{34}$, que o acompanhou durante todo o atendimento, incluindo o período na escola. Além de auxiliar na imitação de gestos, eu acabei criando novos enredos para a personagem (um pássaro chamado Breno) que se assemelhavam ao que Thiago precisava aprender ou elaborar ${ }^{35}$ (como, por exemplo, retirada da fralda, retirada da mamadeira, período de férias, natal, aniversário, mudança de escola) e, com isso, ampliamos muito sua capacidade imaginativa, narrativa e gráfica.

Em 8 meses de atendimento, Thiago, com então cinco anos, já fazia brincadeiras simples de imaginação com miniaturas, contava sobre o que estava imaginando e em alguns momentos conseguia usar um objeto não definido (massinha ou bloco) para representar outro. Interagia integrando mais o contato visual e a fala, a duração do olhar havia ampliado nitidamente e ele respondia ao nome assim que chamado. Também já estava aceitando fazer tentativas de representações gráficas, e de pintar com tinta algum desenho já feito (ou por mim, ou impresso). Não rejeitava mais pintura com tinta e/ou aquarela.

No ano seguinte, quando passei a acompanhá-lo na escola, outras dificuldades foram notadas, principalmente em relação à interação social e à comunicação verbal. É importante ressaltar aqui que Thiago não apresentava dificuldades cognitivas e/ou pedagógicas, de modo que minha presença ali não se fazia necessária por conta de adaptação de material, e sim por questões de mediação e interlocução.

Embora Thiago fosse uma criança que compreendia bastante o que lhe era dito, para a execução de algumas tarefas precisava que eu repetisse passo a passo as instruções, uma de cada vez, conforme ele fosse fazendo. Quando a tarefa requeria um pensamento abstrato, Thiago precisava que eu o auxiliasse trazendo o conteúdo para uma forma concreta, muitas vezes através do desenho.

Ele apresentava baixo tônus muscular nas mãos para atividades que exigissem a motricidade fina, e, por conta disso, tinha a tendência a fazer as tarefas de desenho e escrita de forma simplória e rápida, cabendo a mim, nesses momentos, incentivá-lo a enriquecer o trabalho, e dar suporte para que essa atividade lhe fosse possível. O que muitas vezes

\footnotetext{
${ }^{34}$ Könnecke, O. Vai, você consegue! São Paulo: Brinque-Book, 2007.

35 Algo muito semelhante ao que nos Estados Unidos chamam de Social Stories, que são histórias curtas cujo objetivo principal é identificar e compartilhar informações que ajudam a melhorar a compreensão das situações e expectativas para que o outro possa dar um tipo de resposta mais adequada ao contexto (Gray, C. 2010)
} 
significava, por exemplo, explicar verbalmente como ele deveria pintar, e até mesmo dar um auxílio motor.

Outro ponto era em relação à espera; Thiago precisava, em muitos momentos, de auxílio sobre como esperar, o que fazer enquanto espera, e que a espera é só um tempo, ela passa. Caso contrário, ele ficava aflito, chorava, saia correndo, e esse comportamento era tido como inadequado, tanto para a situação, como para os colegas.

Sobre o relacionamento com os pares, Thiago apresentava algumas dificuldades na interação. Suas brincadeiras costumavam ser mais repetitivas, ele ficava em alguns momentos repetindo diálogos de desenhos, e acabava ficando sem interlocução. Ele tinha dificuldade de participar de uma brincadeira que estivesse ocorrendo no parque, por exemplo, espontaneamente, e de iniciar uma brincadeira com outra criança. Muito disso se devia ao fato de que ele não sabia se explicar, dizer de si, e convidar o outro. Para que ele não ficasse sozinho, ou saísse batendo nos colegas por brinquedos, em alguns dias eu o acompanhava no parque. Nessas ocasiões eu conseguia inseri-lo em jogos coletivos, ensinar a regra, e incentivar que ele brincasse com outras crianças. Além disso, era ocasião para trabalharmos sua fala, para que ele conseguisse interagir de um modo mais adequado, conversando com as crianças, ao invés de bater ou empurrar quando desejasse algo que estivesse sendo usado.

Além disso, Thiago parecia não se importar com os colegas. Se choravam, gritavam ou riam, para ele era indiferente. Se levavam algum brinquedo diferente do habitual, ele se aproximava para ver, nomeava o objeto, mexia se não houvesse ninguém por perto, e se afastava quando as crianças se aproximavam dele para ver do que estava brincando.

Em sala, Thiago não conseguia permanecer na roda de conversa com a turma, aquele momento parecia não fazer sentido para ele; ficava olhando para outros lugares, às vezes repetia diálogos de desenhos que não pareciam estar relacionados ao contexto da aula, ou então começava a imitar sons de animais. Em outros momentos, quando o professor ou alguma criança o perguntava algo simples sobre o que havia acabado de fazer, Thi repetia a pergunta da pessoa, ou então dava respostas "aleatórias".

Todo esse trabalho que desenvolvi com ele, tinha a preocupação de inseri-lo no sentido geral da comunicação do seu grupo. Ou seja, o sentido das brincadeiras, como se entra, o porquê de ele não ser aceito, que ele precisa pedir para participar. Enfim, funcionei para ele como uma intérprete em busca do sentido, como diria Piera Aulagnier ${ }^{36}$.

\footnotetext{
${ }^{36}$ AULAGNIER, P. Um intérprete em busca de sentido. São Paulo:Editora Escuta, 1990.
} 
Até a metade do primeiro semestre, o professor e eu trabalhamos muito para ampliar os recursos de compreensão e fala de Thiago. Fizemos com ele muitas atividades de descrição de imagens, de ações, e até mesmo sobre esse tal de "eu" que Thiago vivia chamando-o de "Thiago", mesmo quando era para referir-se a si. A aposta na comunicação e na linguagem repercutiu em uma maior atenção de Thiago em relação ao contexto e às pessoas ao seu redor; de modo que ao final do primeiro semestre, ele conseguia participar em grupo com os amigos, notava as expressões faciais e sonoras dos colegas, perguntava o que tinha acontecido, e nos contava sobre o que via e acontecia, com ele e com os outros.

O segundo semestre nos trouxe novos desafios. Thiago estava mais alheio após as férias, e com alguns comportamentos muito infantilizados. Com a ajuda das histórias do Breno, criadas especificamente para cada situação, com a retomada da fala como principal forma de comunicação, e com a possibilidade de representar o que estava sentindo pela escrita, Thiago finalizou o ano com novos interesses (super-heróis) e verdadeiros amigos de classe.

No ano seguinte, Thiago mudou para uma escola maior que não permitia o acompanhamento terapêutico, e a família suspendeu as sessões de psicoterapia por questões financeiras.

Vez ou outra temos notícias de Thi por sua mãe, que nos manda fotos e vídeos dele. Breno continua com ele, mas agora ocupando um espaço menor, como deve ser. E disso tudo de toda a aprendizagem da comunicação e interação com os outros, até a construção da própria narrativa - nasceu um Thiago que narra sua própria história, e que também cria outras e publica no seu canal do YouTube.

Na segunda avaliação da ADOS, feita ao final daquele ano, Thiago apresentou grau leve de sintomas relacionados ao autismo.

Seguimos, agora, para as cenas!

\subsubsection{Cenas - "Luisa, conta a história do bebê, do Thi e da Luisa!"}

O título com o qual iniciamos esta parte é um pedido de Thiago, depois uma não tão longa mas muito intensa história que construímos enquanto o acompanhei em terapia e na escola. Mais do que isso, é uma demanda que encerra (contém) todas as demais: é um pedido que me coloca no lugar de protagonista, ao lado dele. Eu sou a narradora e ele (e eu inclusive), em sua história, é o personagem principal. Como se verá, isto se formulou assim depois de nosso trabalho terapêutico com ele. 
Comecemos, porém, com o como a mãe diz das demandas do filho, para que se possa apreciar no decorrer das cenas o percurso do próprio Thiago para fomulá-la do modo como o faz com esse pedido.

O diagnóstico de TEA foi dado aos 3 anos, e o primeiro tratamento terapêutico, por encaminhamento da neurologista, foi ABA. Ele não se adaptou, opôs-se ruidosamente por gritos e agressões. Outros médicos e tratamentos também tiveram destino incerto, provavelmente por suas formas de resistência, nem sempre passivas. Quem é o Thiago que se apresenta nas cenas aqui recortadas?

Um menino que exibe uma beleza cativante, que parece não se importar com isso nem com quem pense isso, que contrapõe espantoso desprendimento em relação ao que o cerca, a uma conduta de bebê que não controla o esfíncter, só toma líquidos na mamadeira e que só se deixa cuidar pela mãe nesses aspectos/momentos. Ou seja: um corpo à mercê da mãe e seus cuidados, caracterizando esse modo muito primitivo de estar no mundo; à mercê, ainda, de ações erráticas, impulsivas, parecendo não dispor de outras formas de comunicação para dizer aquilo que quer, pensa ou sente. Mas também um corpo potente para dar sinais aos olhos atentos desta terapeuta, de que estava atento aos seus gestos e brincadeiras paralelas, e nelas se envolveu evidenciando uma inacreditável competência a envolver-se na narração de histórias, leitura de livros (feitos por mim), bem como ao exercício de uma imaginação ímpar que acabou por adotar uma personagem ao ponto de uma profunda relação identitária com ele, o Breno!

Foi na evolução dessa história, acompanhando-o, das sessões no consultório ao cotidiano escolar, que ele conseguiu atingir uma fala que admite um "eu" como sujeito de ações e lhe dá confiança para revisitar seu tempo de bebê, as perdas e os ganhos que foi fazendo até retomar o Thi que solicita a mim que conte sua história, incluindo esse personagem importante que é o narrador, eu, como parte das relações e cenas narradas.

Se este é o momento em que instauramos as cenas relatadas neste trabalho de doutorado, é porque consideramos que o leitor não precisará de mais ninguém a não ser o próprio ThiBreno para se convencer dos alcances de sua terapia, para ascender ao lugar muito especial de autoria da própria história, ainda que com um texto inventado por sua terapeuta, mas de que se apropriou, heroicamente, no exercício de autonomia como sujeito desse e nesse processo todo.

Cena 1

Hoje na sessão Thiago permitiu, literalmente, que eu interagisse mais com ele e os livros da Disney. O primeiro livro que ele pegou nós só vimos as figuras juntos, no segundo eu fui comentando as imagens, e quando ele parava em alguma página e eu não falava nada, ele olhava para mim como um pedido para que eu falasse algo sobre 
a imagem. Então eu falava, e ao final da minha fala ele virava a página. Depois de vermos todos, eu comecei a comentar qual daqueles livros eu já conhecia a história e quais não. Ele olhou bastante pra mim nesses momentos. (Anotações pessoais, dois meses de atendimento, Thiago com quatro anos e seis meses)

Temos aqui uma comunicação sintônica, em que há sentidos claros de atenção minha aos comandos dele, e dele em relação aos meus comandos.

\title{
Cena 2
}

Hoje, depois de vermos todas as imagens dos livros da Disney, Thiago foi até a caixa de livros e tirou outros de lá, acho que ele estava em busca de mais livros da Disney, mas não encontrou. Quando eu fui pegar um livro pra mostrar pra ele, ele fez um barulho parecido a um rosnar, e virou de costas para mim. Mesmo assim eu peguei o livro que eu queria, e o convidei para ver comigo. Ele aceitou, e acabou gostando bastante! Apontava os animais no livro e esperava atentamente que eu dissesse o nome deles. (Anotações pessoais, dois meses de atendimento, Thiago com quatro anos e seis meses)

Nesta cena, o som que ele faz, e seu virar de costas, poderiam ser interpretados como uma recusa ao livro que eu havia pegado. Mas frente ao meu convite e à minha persistência em pegá-lo, apesar de seus sons e movimento, ele aceita a proposta e consegue até sentir prazer em fazer parte dela.

\section{Cena 3}

\begin{abstract}
Hoje Thi escolheu o livro do Dumbo para lermos na sessão. Eu não sabia a história, já tinha dito isso para ele, e como tem muito texto, ele também não tinha muita paciência de esperar eu ler tudo de cada página. Então, avisei para ele que por ser uma história desconhecida para mim, eu iria inventar uma com as imagens. Logo na primeira vez que eu contei, ele já sorriu em alguns momentos. Depois, pediu para eu repetir, e então eu arrisquei e disse que seria outra versão, diferente da primeira e da original, e ele aceitou que eu contasse até o fim. E essa brincadeira durou quase a sessão toda, e ele sorria e ria em algumas partes, estava se divertindo. Para quem precisava enfileirar livros e vê-los na ordem, até que ele está se saindo bem! (Anotações pessoais, três meses de atendimento, Thiago com quatro anos e sete meses)
\end{abstract}

Veja, eu respeito o que acho que poderá irritá-lo (o fato de eu não saber a história e contar de outro jeito para ele). Explico (inventaria uma outra com as imagens). Ele aceita. $\mathrm{O}$ que ele aceita? As múltiplas versões que alguém pode dar a história...

\section{Cena 4}

O livro do Rei Leão veio depois do Dumbo. Como essa história eu sabia, conseguimos ver mais detalhadamente as imagens e ele se divertiu primeiro ao me ver cantando Hakuna Matata, sorriu e deu risada. Algumas sessões depois, começou a cantar comigo. Eu apresentei para ele os personagens de plástico do filme, e começamos uma brincadeira de tentar encenar com eles. Eu ia contando a história e Thi fazendo 
as cenas no parapeito da janela, sem dizer uma palavra, apenas me olhando e sorrindo vez ou outra. (Anotações pessoais, três meses de atendimento, Thiago com quatro anos e sete meses)

Como na cena anterior, nesta eu produzo o enredo e reapresento o conhecido (a história, a música). O efeito: prazer e variação!

\title{
Cena 5
}

\begin{abstract}
Passamos um mês lendo o livro toda a sessão, Vai, você consegue ${ }^{37}$. Ele se divertia tentando ler algumas frases do livro. Até que em uma sessão eu desenhei o Breno no espelho, e depois no papel. Nesse dia, ele quis levar o papel para a casa dele. Na sessão seguinte, a mãe contou que ele colocou o desenho no quarto dele, e no dia seguinte, quando acordou e viu, falou "Bom dia, Breno". Pouco depois, passamos a imitar os gestos do Breno no livro fisicamente, e ele começou a me pedir para desenhar a história inteira. Ensinei-o a pedir "Desenha, Luisa", e assim ele fazia, ao colocar o livro na mesa. Aguardava pacientemente que eu terminasse os desenhos, e eu pedia que ele escolhesse se seria só de preto ou colorido, e ele sempre escolhia colorido. Assim, fizemos muitas "cópias" da história! (Anotações pessoais, quatro meses de atendimento, Thiago com quatro anos e oito meses)
\end{abstract}

Temos aqui o registro da evolução da produção de um texto. Eu capitaneio um enredo, mas Thiago é quem toma assento nas cores, ao ponto de levar Breno para casa e dizer-lhe "Bom dia" quando acorda. Apossa-se dessa história e a anima também. Os pedidos para que a terapeuta prossiga com os desenhos, com a atribuição de um corpo ao que só a imaginação estava sustentando. Aqui ele está lidando com um aspecto desta e de qualquer outra realidade cotidiana e não inventada: a variabilidade, o movimento.

Minha anotação final, de que fizemos muitas "cópias" da história, é bastante significativa da coautoria de Breno, já nas múltiplas versões para além do roteiro inicial.

\section{Cena 6}

Logo após a primeira semana de aula de Thiago na escola nova, ele pediu a caixa de Lego para brincar. Começou juntando algumas peças ao bloco da janela, e eu fiz uma árvore. Ao ver o que eu tinha feito, ele exclamou "A casa na árvore!". Eu disse que ele devia estar lembrando da escola nova, porque sua mãe havia me contado que ele tinha gostado muito daquele espaço na escola. Ele sorriu, colocamos a janela dele em cima da minha árvore e ele colocou vários bonecos em cima da janela, provavelmente representando a brincadeira que fez na escola. (Anotações pessoais, quatro meses de atendimento, Thiago com quatro anos e oito meses)

Thiago começa com o que sabe: enfileirar, juntando as peças. E eu entro com uma figura.

Tudo às claras, e a montagem de uma cena com enredo pode prosseguir.

${ }^{37}$ (Könnecke, 2007) 


\title{
Cena 7
}

\begin{abstract}
Após quase duas semanas de aula na escola nova, deixei disponível para Thi o Playmobil da escola. Sem dizer uma palavra, ele fez a seguinte brincadeira: colocou as crianças na sala, a professora na lousa, uma criança e uma mãe na porta da escola. Em seguida, fez a criança que estava com a mãe indo para a sala, a mãe na recepção, e depois a mãe saindo da escola. Depois, a mãe voltando, pegando o filho e indo embora. Após toda essa cena, igual ao que acontecia com ele, ele quis guardar. (Anotações pessoais, quatro meses de atendimento, Thiago com quatro anos e oito meses)
\end{abstract}

Eu ofereço um brinquedo que pode evocar lembranças importantes para o Thiago, e faço isso de caso pensado, uma vez que sabia de sua mudança de escola, e na sessão anterior tínhamos feito a casa na árvore da escola nova com blocos de lego. Ele me responde à altura: dizendo dele como autor de uma história numa brincadeira móvel que repete a sua. Parece bem plausível considerar isso como a criança remontando o que nem sempre lhe é agradável, colocando-se como quem lhe dá começo, meio e fim, e assim repete e controla ao mesmo tempo seus efeitos. Até porque ele quis guardar o brinquedo em seguida. Mas que essa interpretação seja de foro íntimo, como foi no caso do Thi.

Cena 8

Em agosto, com a mudança de escola, demos início ao desfralde de Thi. Para iniciar esse processo, fiz para ele um livro com um passo-a-passo de o que fazer tendo o Breno como personagem. Primeiro ele entendeu como brincadeira, e fez toda a sequência imitando, como se fosse como fazíamos com a história original. Depois, com as repetições "na vida real", ele foi entendendo como fazer. Deixei uma cópia na escola, outra em casa e outra no consultório. Repetindo o texto simples e lembrando das imagens, ele aprendeu com facilidade o que deveria fazer. Até porque, nos primeiros escapes de xixi, ele ficou muito incomodado de ficar molhado! (Anotações pessoais, cinco meses de atendimento, Thiago com quatro anos e nove meses)

Meu espaço de invenção da história foi facilitado pela história que havíamos construído juntos, a partir e com o Breno. Agora, a história do Breno no banheiro servia também para facilitar um espaço para Thiago ter consciência de seu corpo e de suas demandas, em todos os sentidos... E as cópias do livro foram para os lugares em que previ que esse espaço de Thi poderia lhe ser facilitado.

\section{Cena 9}

Como o livro do desfralde era com o personagem Breno, e ele repetia inúmeras vezes as frases do livro, as professoras e crianças da escola começaram a querer saber quem era esse personagem. Então, um dia, eu fui convidada a participar de um momento de roda com a turma dele, e o livro original. Thi estava muito feliz de eu estar ali. Ele sentou no colo da professora e contou para a turma a história orginal, que sabia de cor. 
Ele contava muito orgulhoso, estava compartilhando algo que a partir daquele momento, passou a fazer sentido para as outras crianças também. (Anotações pessoais, cinco meses de atendimento, Thiago com quatro anos e nove meses)

Da produção em coautoria à comunicação e socialização. Thi já era Breno e seu criador.

Para todos os efeitos, se autoapresentava...

Cena 10

Thiago, quando não queria algo, fosse brincadeira, jogo ou história, vinha de corpo inteiro para cima de mim, me empurrando com a cabeça, ou então, pegava o objeto e jogava longe. Disse para ele, algumas vezes, que ele não precisava agir desse modo, que se ele me falasse "não" ou "não quero" ou "guarde" eu entenderia melhor e seria mais confortável para nós dois. Foi um processo; Thiago conseguiu entender que a palavra tinha uma função, função esta que ia muito além da descrição de cores, formas, animais e nomes. As palavras comunicavam algo, e isso ele aprendeu e continua aprendendo. (Anotações pessoais, seis meses de atendimento, Thiago com quatro anos e dez meses)

Esta cena é autoexplicativa. O discurso está no contexto.

As cenas que se seguem, foram retiradas do período em que eu acompanhei Thiago na escola.

\section{Cena 11}

Outro ponto importante era (e ainda é) a fala dele em terceira pessoa. No começo isso era mais acentuado; o Thiago era o narrador de sua história, assim como há no Pocoyo o narrador da história. A inversão pronominal era regra. Conversei com o professor, e passamos a solicitar incansavelmente que o Thiago dissesse "eu" ao dizer de si. Eu levei para a escola o livro $E u^{38}$, da Janaina Tokitaka, para trazer essa palavra para o discurso das crianças e incentivá-lo a usar o pronome, e entender melhor o sentido do seu uso.

O professor considerou que esse era um aprendizado pertinente, e leu o livro com as crianças por dias, conversando a cada página sobre quem era esse "eu”, que as pessoas falam como se fossem elas, cada uma em particular, mas todas usam a mesma palavra para dizer de si. Não sei dizer, ao certo, o que ficou para o Thiago sobre essas conversas e discussões. Posso dizer apenas da repercussão em seu discurso nas cenas que se seguem.

Ao terminarem de ler o livro, o professor pediu para as crianças pensarem em quem elas gostariam de ser e fizessem um desenho sobre essa pessoa/personagem/animal, enfim. Conhecendo o Thiago, essa poderia ser uma tarefa difícil, pois envolvia pensar em personagens, escolher uma, e esta representar quem ele gostaria de ser. Teria ele entendido isso de escolher outro alguém que quisesse ser? Não sei, tínhamos que tentar e descobrir juntos.

Repeti o pedido do professor para ele e aguardei uma resposta. Thiago ficou em silêncio. Decidi ajudá-lo dando alguns exemplos; falei nome de animais pelos quais sei que ele se interessa, nome de pessoas da família e de colegas de classe, e de personagens de seus desenhos favoritos. Ele ia dizendo "não" para alguns, para outros não dizia nada. Fomos sentar à mesa, quando resolvi repetir o nome dos que ele não havia dito nem que sim, nem que não, e no meio deles me lembrei de um, o Breno ${ }^{39}$,

38 (Tokitaka, 2014)

39 (Könnecke, 2007) 
e acrescentei-o em minha fala. Ele aguardou eu falar todos, e então disse alto e com alegria "O Breno! O Thi é o Breno! Eu sou o Breno!". E começou a desenhar, lembrando de cor a imagem do personagem! Quando terminou o desenho, o professor perguntou quem ele tinha escolhido ser, e ele respondeu "O Breno!", e então o professor perguntou quem era o Breno, e ele respondeu prontamente "O pássaro!". As crianças que conheciam o livro logo reconheceram, e comentaram com ele e com o professor a história!

Este foi um momento muito significativo no acompanhamento do Thiago. Foi uma das raras vezes em que ele respondeu, de imediato e sem ajuda, a uma pergunta. Sobretudo, foi uma das raras vezes em que ele usou o pronome "eu" adequadamente e de forma espontânea, e ainda para dizer de si como um outro. Estava dita, ali, sua identificação com o personagem, e esclarecido o motivo de as histórias que eu criei para ele com o Breno terem dado tão certo e terem sido tão importantes para ele em relação à sua organização interna sobre o que e o como deveria fazer algumas coisas (fazer xixi e cocô na privada, tomar líquidos no copo), e entender algumas situações (aniversário, férias). Outros momentos depois deste apareceram, e o Thiago vem dizendo cada vez mais desse "eu" que é só (d)ele. (Relatório escolar, um ano de atendimento, Thiago com cinco anos e quatro meses)

\section{Cena 12}

(...) Por fim, o professor leu mais uma parte do livro ${ }^{40}$ que eu trouxe para ele ler para as crianças, para ajudar o Thi a falar "eu". Ao final, ele pediu que cada criança fizesse uma frase usando o modelo "Eu gosto de...". E o Thi fez a frase dele sozinho, sem nenhuma ajuda: "Eu gosto de me mexer". (Anotações pessoais, onze meses de atendimento, Thiago com cinco anos e três meses)

\section{Cena 13}

(...) o professor retomou com as crianças o Picasso e o modo dele pintar, e as crianças pintaram, com giz e lápis, uma cópia preto e branca do autorretrato dele. Nesse momento de pintar, eu disse pro Thi: "Thithi, faz assim como giz, vai e volta, vai e volta, assim você consegue pintar", e ele fez! E a Clara falou toda feliz para mim e para ele: "Você está ensinando ele a pintar!". Normalmente ele não pinta desse jeito, ele não pinta de fato os desenhos, ele faz apenas uma linha no lugar que seria para pintar. Desse jeito deu certo, e ele até passou a repetir comigo "vai e volta, vai e volta". (Anotações pessoais, um ano de atendimento, Thiago com cinco anos e quatro meses)

Nota-se que nesta cena eu não me poupo de ensinar-lhe ao que de tão simples e esperado de qualquer criança naquela idade, costuma-se julgar "natural” fazer. Para Thi não era.

\section{Cena 14}

Notei que quando o Thiago ficava bravo, ele batia automaticamente, parecendo nem dar tempo de pensar ou falar, só de bater. Passei, então, a ficar bem atenta a ele, a todos os seus movimentos, no parque. Quase não mediava as brincadeiras para ver o que iria acontecer, e... quando ele levantava a mão para bater, eu rapidamente segurava sua mão e dizia "Thiago, não pode bater. Se você não gostou, fala". Nas primeiras vezes em que isso aconteceu, ele me olhou assustado e abaixou a mão. Eu, então, dei um modelo sobre o que ele poderia falar, e mais do que de pressa ele repetiu. E aí, em

${ }^{40}$ (TOKITAKA, 2014). 
ato, fui auxiliando-o a lidar com a frustração, a entender o que é uma espera, e dando recursos de linguagem para se comunicar em seu contexto.

Em um segundo momento, novamente em situação de conflito por brinquedo, Thiago passou a levantar a mão para bater, abaixar rapidamente a mão, e falar "não pode bater!" e olhar para mim, com a intenção de eu ajudá-lo a resolver a situação. Atualmente, são raras as vezes em que ele levanta a mão para bater, e o mais comum tem sido ouvi-lo dizendo "não pode bater! Tem que esperar", e logo após um olhar para mim ansiando meu reconhecimento por sua postura. (Anotações pessoais, um ano de atendimento, Thiago com cinco anos e quatro meses)

Eis aqui uma cena de desnaturalização em ato: eu proponho e Thiago entende e aceita um lugar para o pensamento e palavra entre o impulso e o gesto! A cena anterior, do desenho, também nos mostra essa desnaturalização, mas sobretudo para o adulto que não para para observá-lo.

Cena 15

(...) Fiquei com ele no parque após o lanche, e apenas uma vez ele levantou a mão para bater. Levantou para bater no Gabi, enquanto montavam um quebra-cabeça, porque queria uma peça. Rapidamente eu falei "Thithi, não bate!", e ele conseguiu não bater e falou "Me empresta, Gabi?". Estamos conseguindo! (Anotações pessoais, um ano de atendimento, Thiago com cinco anos e quatro meses)

\section{Cena 16}

(...) fizemos maçãs de argila em referência à história da deusa grega Éris. Thiago estava com bastante nojo da argila, só conseguiu mexer quando eu falei "Thi, na argila você pode bater, aproveita! Nos amigos não pode, mas na argila pode!”. Ele bateu com força e vontade, deu até risada! (Anotações pessoais, um ano de atendimento, Thiago com cinco anos e quatro meses)

Temos aqui uma extensão descontraída de uma aprendizagem que estava sendo tão custosa para o Thiago: nessa argila/maçã pode bater.

Cena 17

Passamos alguns dias sem que tivesse nenhum confronto físico por brinquedos ou jogos. Até que então, inesperadamente no parque, fui pegar um brinquedo da areia para brincarmos juntos, e quando olho procurando o Thi, vejo ele sentado na escada da casa da árvore dando um tapa na criança ao seu lado, também sentada, que imediatamente começou a chorar. Ele, Thi, me olhou assustado, e falou em terceira pessoa: "O Thithi bateu!". Perguntei o que havia acontecido, e ele não conseguia me dizer o que era. A criança em que ele tinha batido, o Fernando, é um ano mais nova, também está dentro do Espectro do Autismo, e quase não fala. Coube a mim, então, levantar hipóteses e contar com a ajuda de Thiago para esclarecer o ocorrido. Perguntei se ele queria pegar o dinossauro do Fernando, e o Fernando não quis emprestar, e ele disse que não. Fiquei pensando mais um pouco, lembrei de ter visto o amigo sentado na escada antes do Thi tentar subir, e aí perguntei: "você queria subir e ele estava no meio da escada?" e ele respondeu que sim e tentou voltar a subir na escada. Eu o segurei e disse que ele estava errado de bater, que ele poderia ter falado 
com o amigo ou me chamado, e que agora precisávamos cuidar do amigo. Acalmei o Fernando com um carinho em sua cabeça, e Thiago aguardou. Pedi para ele pedir desculpa, ele pediu e os dois subiram para a casinha.

Lá em cima, o Fe voltou a chorar, e o Thi começou a me chamar para brincar insistentemente. Foi quando eu falei "Thiago, você bateu no Fernando e agora nós precisamos cuidar dele. Ele não consegue se comunicar direito, falar (nessa hora, ele parou de falar para eu brincar com ele e ficou prestando atenção ao que eu dizia, o que me fez pensar que talvez ele estivesse se reconhecendo), e ele está chorando. Nós precisamos ver se ele está bem, e só vamos brincar quando soubermos disso". Voltei minha atenção ao Fe, acalmei-o novamente, e Thiago aguardou ao meu lado. Pudemos depois, então, continuar a brincadeira.

De toda essa parte, o que mais chama a atenção é o como ele ficou mobilizado com a minha fala sobre o Fernando, provavelmente se reconhecendo, ou se lembrando de como era antes de conseguir dizer melhor de si algumas coisas. E também sobre o cuidado e a possibilidade de se acalmar, tanto Fernando, quanto Thiago.

Depois desse dia, quando o Thithi vê alguém chorando, ele corre até mim e diz que a criança está chorando, e pergunta o que aconteceu. Fica ali olhando, esperando, até a criança ficar bem. Se ele ainda bate? Às vezes, porém é bem mais raro. Agora ele cuida também. (Relatório escolar, um ano e dois meses de atendimento, Thiago com cinco anos e seis meses)

Ressaltamos, aqui, a confiança mútua: eu sei que ele não mentiria para mim, e ele de fato se põe a falar não em causa própria...

\section{Cena 18}

Hoje tivemos um avanço muito importante. Antes, quando eu não estava próxima ao Thi, ele começava a chorar e gritar. Hoje, não. Hoje ele conseguiu fazer como eu havia pedido que ele fizesse quando quisesse que eu ficasse mais perto dele; ele foi até mim e falou "Vem, Luisa!". Ele fez isso no parque de areia para eu ficar próxima ao balanço, quando quis que eu fosse ao lado dele para o refeitório, entre outras situações. (Anotações pessoais, um ano e um mês de atendimento, Thiago com cinco anos e cinco meses)

Cena 19

Hoje no parque da areia o Thi brincou de ponte com a Giulia! Começou com ela passando por baixo das pernas dele, e depois, ela pediu que ele passasse por baixo das pernas dela. Ele ficou com um pouco de receio no começo, mas com alguns incentivos que fiz, ele foi! Em seguida ela pegou a boneca dela, a Vitoria, para brincar e convidou a mim e ao Thiago. Nós sentamos para brincar com ela, e ela disse que era aniversário da boneca, e que iria pegar algumas folhas para fazer o bolo, e deixou a boneca com Thi. Ele se divertiu! Pegou no colo, colocou a chupeta, e depois até aceitou cantar o parabéns! Olha só que diferença da primeira avaliação da ADOS! (Anotações pessoais, um ano e um mês de atendimento, Thiago com cinco anos e cinco meses)

\section{Cena 20}

Hoje pela primeira vez eu vi o Thithi compreender um jogo de regra e demonstrar não estar gostando de perder! Era um jogo de encontrar figuras iguais, jogamos ele, a Elis e eu. Quando a Elis encontrava alguma carta igual antes dele, ele dizia "É a vez do Thihi! A Elis tem que demorar... Ahhhh!”. Ele está aprendendo sobre esse mundo... 
(Anotações pessoais, um ano e dois meses de atendimento, Thiago com cinco anos e seis meses)

\section{Cena 21}

Percebi, aí, que o Thiago não conseguia contar coisas que tinha feito e responder perguntas simples sobre isso. Conversei com o professor e passamos a perguntar com mais freqüência ao Thiago o que ele tinha feito, e a ajudá-lo a responder: quando o professor perguntava algo que ele não sabia dizer, eu dizia baixinho para ele e ele repetia para o professor, e vice-versa. Ou então, nós dávamos duas alternativas (uma que correspondia ao fato e outra não), e pedíamos para ele dizer qual delas era, e após algumas repetições das duas alternativas ele conseguia escolher uma só e dizer qual era. Outra coisa que fizemos foi uma pasta com algumas imagens do que ele havia feito em sala, em casa ou no consultório, e de tempos em tempos olhávamos e íamos perguntando o que era, o que ele tinha feito. Também fizemos inúmeras descrições sobre o que ele e outras pessoas estavam fazendo para estimulá-lo.

Aos poucos, Thiago foi conseguindo nos contar coisas e descrever ações suas e de colegas, como "Luisa, eles saíram correndo para longe" (quando sua turma tinha mesmo saído correndo da sala para a biblioteca) ou "O Thiago vai fazer o barco" (dobradura de papel).

(Relatório escolar, um ano e dois meses de atendimento, Thiago cinco anos e seis meses)

Temos aqui a atenção constante da terapeuta como condição de aprendizagem, porque um terapeuta pode sim facilitar para a criança a narrativa de si, das próprias ações, criando uma situação de aprendizagem em clima de confiança mútua.

Descrever ações é tão importante quanto posicionar-se nelas! E a terapeuta aposta nessas capacidades de Thiago para ultrapassar limites que muitas vezes, quem o cerca, ou atribui a um problema especial, ou acha que vão se desenvolver com a idade.

\section{Cena 22}

$\mathrm{Na}$ primeira semana de volta às aulas, após as férias de julho, Thiago estava bem diferente, em diversos aspectos. Interagindo menos com as pessoas, não querendo tomar lanche, só querendo o patinete. Além disso, acho que algo fez com que ele perdesse um pouco da confiança nele mesmo na escola.

Em um dos primeiros dias o professor pediu para que a turma descesse para o lanche. Thiago saiu na frente, e eu o avisei que iria pegar uma água para mim e já iria. Bem, ele desceu as escadas da sala dele para o térreo, e quando chegou no último degrau começou a gritar: "Luisaaaaaaa! Estou perdido!". Certamente não era apenas ao espaço físico que ele estava se referindo... (Anotações pessoais, um ano e quatro meses de atendimento, Thiago com cinco anos e oito meses)

\section{Sendo ou não do espaço físico, Thiago estava dizendo de si!}

\section{Cena 23}

(...) A volta às aulas foi bem difícil para o Thiago. Em sala, ele ficava o tempo todo falando de histórias do Pocoyo e misturando o Breno e o Pocoyo. Até que uma hora 
eu falei pra ele "Nossa, Thi, deve estar a maior confusão aí na sua cabeça, né?! Você está misturando o Breno com o Pocoyo!!!". Ele ficou me olhando, atento e em silêncio, e depois não fez mais essa "mistura". (Anotações pessoais, um ano e quatro meses de atendimento, Thiago com cinco anos e oito meses)

Note que o que poderia parecer, a ouvidos desavisados, de que Thiago estava evoluindo em sua brincadeira imaginativa de Thiago, naquele contexto, e considerando sua história, parecia confusão. Ao dizer isso para ele, ele também pôde se organizar.

Há uma relação de confiança entre nós dois porque eu falo de "confusão aí na sua cabeça", de forma denunciativa e leve, e ele parece esperar essa minha fala para organizar "alguma bagunça interna".

Cena 24

Hoje ele estava bem sensível. Bastava o professor chamar sua atenção para o que estava acontecendo ou pedir algo para ele, que ele começava a chorar. Também ficou bem triste quando uma amiga demorou para colocar a fruta dela no painel. Nessas situações eu conversei com ele dizendo que percebia que ele estava muito sensível, mas que ele não precisava chorar quando as pessoas pediam algo para ele, porque se elas pediam era porque ele conseguiria dar conta de fazer, e que às vezes teríamos mesmo que esperar e que isso também fazia parte, também era um pedido que poderíamos conseguir fazer. (Anotações pessoais, um ano e quatro meses de atendimento, Thiago com cinco anos e oito meses)

Nesta cena fica claro que eu aposto até o fim na condição de ele entender o que eu lhe falo. Em contrapartida, Thiago costuma apostar no como eu entendo as coisas, como se isso pusesse ordem em seus pensamentos e corpo, na hora.

Cena 25

Hoje no lanche Thi resistiu bastante a tomar o suco no copo. Ele deu um gole e depois começou a falar "chega de copo!". O professor perguntou se ele queria mamadeira e ele disse que sim. Então, eles foram ao berçário ver se tinha uma para o Thi, mas não tinha... Tinha só para bebês! Thi ficou super triste, chorou, mas foi muito bem acolhido pelo meu colo e do professor. Voltamos ao refeitório, ele fez mais algumas tentativas, e conseguiu tomar mais um pouco no copo. (Anotações pessoais, um ano e quatro meses de atendimento, Thiago com cinco anos e oito meses)

\section{Cena 26}

Apostando na identificação dele com o personagem Breno, criei uma história em que o Breno tinha que deixar a mamadeira e tomar suco no copo, e fazia isso mandando por uma bexiga a mamadeira dele para outro ninho, um ninho que tinha um passarinho bebê. Levei para a escola e o professor leu para as crianças na roda de leitura, ao final do dia. Thiago prestou muita atenção. Nos dias que se seguiram, ele decorou a história, e em uma atividade sobre os abacates ele até chegou a usar a forma do abacate representando uma bexiga e desenhou uma mamadeira dentro! 
Dias depois, Breno passou do papel para o mundo concreto. Fiz de feltro os personagens dessa história, intitulada de "Breno está crescendo". E nós levamos o ninho que receberia a mamadeira do Breno para onde os bebês na escola usam mamadeira: no berçário. Ficou lá, para eles, de presente do G5. Acho que o Thiago conseguiu entender seu lugar de criança, na escola. E, desde então, ele toma suco no copo e não voltou mais a falar de mamadeira! (Anotações pessoais, um ano e quatro meses de atendimento, Thiago com cinco anos e oito meses)

A organização e representação, ainda que feita por mim inicialmente, ressoa em Thiago. Fica em sua memória, e ele mesmo passa a conseguir reproduzi-la com os recursos que dispõe. Internaliza, e segue.

Cena 27

Hoje na aula de música, Thiago chegou super animado dizendo que iria tocar a gaita. No momento em que os instrumentos ficaram disponíveis para as crianças, ele logo pegou a gaita e tocou bastante, muito feliz. A professora de música sugeriu, então, de uma criança por vez ser o maestro da turma. Primeiro foi a Clara, e em seguida a vez do Thiago.

Thi não entendeu que o movimento que ele fizesse com as mãos iria conduzir o modo como as crianças iriam tocar os instrumentos, e então, ele mexeu bastante as mãos, e bem rápido! Logo o espaço foi tomado por um grande barulho, e Thithi, aflito com ruído, começou a gritar "Chega! Chega!". A professora conversou com ele, explicou o que havia acontecido e conduziu com ele a turma por mais um tempinho.

Quando Thiago voltou para tocar, as crianças tinham que trocar de instrumento entre elas. A princípio Thi aceitou, e passou a gaita para uma colega. Mas, em seguida, vendo que teria que escolher outro instrumento, pediu de volta. Eu expliquei para ele o que era trocar, que ele precisaria escolher o instrumento de outro amigo, e ele pegou uma flauta. Pegou a flauta e imediatamente assoprou, bem forte, o que fez com que ela emitisse um som agudo e alto. Ele ficou muito bravo e começou a falar que a flauta tinha feito muito barulho. Conversei com ele sobre ele ter produzido esse barulho na flauta, sugeri que ele escolhesse outro instrumento, ele escolheu os cocos, mas logo a aula acabou.

Chegando na sala, sua turma sentou em roda, e Thi não conseguia prestar atenção no que estava acontecendo; ficava o tempo todo falando para mim "a flauta fez um barulhão!”. O professor, inicialmente, deu espaço para Thiago contar o que havia acontecido, mas depois disso, começou a pedir que Thiago prestasse atenção ao que estava acontecendo naquele momento, e Thi simplesmente não conseguia. Então, o professor pediu que ele fosse terminar de conversar comigo, fora da sala, e voltasse quando o assunto tivesse sido encerrado. Saímos da sala e eu sugeri ao Thi que fossemos contar para a professora de música o que tinha acontecido quando ele tocou a flauta, e como ele se sentiu. Ele quis, ela estava disponível, e tivemos uma conversa cheia de perguntas (nossas) e respostas (dele). Ao final, a professora disse que era ele que mandava no instrumento, e não o contrário! E ela o ensinou a tocar a flauta bem fraquinho...! (Anotações pessoais, um ano e quatro meses de atendimento, Thiago com cinco anos e oito meses)

Nesta cena, nos mostra como o entendimento de Thiago sobre algumas situações era inicialmente, de certa forma, pequeno quando comparado a uma criança de mesma idade (trocar, tocar a flauta). Mostra também como ele se sente invadido por situações que lhe ferem os sentidos (ultrapassando um limiar aceitável para ele) no sistema perceptivo. 
Nossa saída é a de tentar explicar para ele as situações (troca, som da flauta), mas também de pedir ajuda para quem (professora de música) poderia entender melhor do que nós dois sobre o barulho da flauta, e tanta perturbação nele em decorrência do som produzido.

Ao final, conseguimos (eu e a professora) ensinar para Thiago a conhecer a força que imprime em suas ações e os efeitos disso nele mesmo.

Cena 28

Recentemente, fomos ouvir na sala do G4 uma história contada pela professora do G1, com os alunos do G1 também. No meio da história, Thiago e Diogo (G4) começaram a tentar pegar os bonecos de super-herói que estavam próximos a eles, quando uma criança do G1 foi lá e pegou tudo. Os dois mais velhos começaram a falar alto e tentar pegar da mão do menor. O professor do Thiago explicou para eles que, além de não ser o momento, eles eram mais velhos, já tinham 5 anos, e a criança que pegou tinha 1 ano; eles conseguiam esperar bem mais. Na hora o Thiago desentendeu e ficou repetindo a explicação pra mim com voz de choro. Então, eu expliquei de novo dizendo que a criança do G1 era muito pequena, era um bebê, e que ele era uma criança grande. Rapidamente, ele entendeu e se conformou com a espera. Em outro dia, aconteceu algo semelhante no parque da areia, e ele imediatamente falou para mim “ele é pequeno, ele é bebê, o Thiago consegue esperar", e esperou pelo brinquedo que queria. (Anotações pessoais, um ano e cinco meses de atendimento, Thiago com cinco anos e nove meses)

Aqui podemos destacar a força do vínculo e da confiança que Thiago estabeleceu comigo; a explicação do professor, uniforme para Thi e Diogo não conseguiu ser muito apreendida por ele. Mas, comigo, em confiança, ele conseguiu tomar o ensinamento para si.

Cena 29

(...) Brincamos de macaco com a Giu, e eu coloquei as crianças em cima da árvore da casinha. O Thi adorou, e quando estava sentado lá, disse "O macaco Thiago, o senhor peixe e a estrela do mar estão na árvore. E a Luisa está aqui!" e deu uma grande risada de felicidade. (Anotações pessoais, um ano e seis meses de atendimento, Thiago com cinco anos e dez meses)

Tão importante quanto conseguir brincar e imaginar, é poder confiar e compartilhar com alguém de quem se gosta esses momentos.

Cena 30

O G5 estava na sala do G4, quando a Renata, professora do G4, organizou uma brincadeira de Sumô (tem um circulo, duas crianças ficam no meio, se abraçam e uma tem que tentar empurrar a outra para fora do círculo. Quem sair do círculo perde). Foram dois meninos, primeiro, depois o Thiago disse que queria ir. Pedi para ele falar com a Renata, e ela organizou para que ele fosse junto com o João (G4). Rapidamente a luta deles terminou com o Thi para fora do circulo. As crianças aplaudiram, gritaram comemorando, torcendo, e o Thiago começou a agradecer, a dançar no meio do círculo, feliz como um campeão (seja lá o que ele tenha entendido do desfecho, estava se sentindo um campeão pela sinergia dos aplausos). 
Outras crianças foram para a disputa e ele, sentado no meu colo junto com a Marina, assistiu. Chegou a vez da Marina, e ela foi lutar com a Ana Laura, toda feliz. Marina saiu, também, rapidamente do círculo. Diferente do Thiago, ela percebeu que havia perdido e pôs-se a chorar. A professora dela deu uma acalmada e ela veio para o meu colo ainda em lágrimas.

O Thiago perguntou porque ela estava chorando, e eu respondi que era porque ela havia perdido na luta e estava triste. Ele olhou para mim, olhou para ela, olhou para as crianças que estavam lutando e começou a chorar. De escorrer lágrima e soluçar. Perguntei o que tinha acontecido e o motivo de ele estar chorando e, algum tempo depois, ele disse "O Thiago tá chorando... soluço... porque o Thiago perdeeeeeeu... soluço". Então eu disse "Ah, Thi... você conseguiu perceber isso agora, né?! Mas olha, é assim mesmo neste jogo... um perde e o outro ganha... Mas você vai ter chance de jogar de novo, e aí poderá conseguir ganhar!". Ele enxugou as lágrimas e foi tomar lanche. (Anotações pessoais, um ano e sete meses de atendimento, Thiago com cinco anos e onze meses)

A percepção, às vezes, vinha com certo "atraso" para Thiago, e muitas vezes ela se dava após a observação que ele mesmo conseguia fazer dos colegas e do contexto. Thi não estava mais fechado em si mesmo, embora ainda tivesse características do TEA.

Cena 31

Quando o Thiago cresce, entende que é criança, nossas solicitações a ele fazem sentido para ele também, não mais só para nós. E, com isso, ele cresce mais um pouco. Chorar porque que quer ou não quer algo não é mais aceitável, e ele consegue dizer usando palavras. Ele se esforça, por vezes tropeça nas sílabas, nos tempos, mas vai. Foi assim que ele nos contou que tinha ficado chorando no carro ao vir para a escola porque sua mãe não tinha comprado a mochila do Pocoyo que ele tinha visto na loja. E conseguiu, depois, elaborar o ocorrido desenhando a história, parte por parte. Foi assim, também, que quando eu voltei de viagem, meio que se recusando a fazer a atividade proposta e não querendo brincar comigo, saiu um "o Thiago quis mataaaaar a Luisa", com uma garrafinha de água na mão apontada na minha direção. Eu disse que estava percebendo que ele tinha ficado muito bravo comigo, mas que eu já estava de volta, e ele repetiu "o Thiago ficou muito bravo". Aceitou escrever a palavra "bravo" com nossa ajuda, para, em seguida, ficar tudo bem. (Anotações pessoais, um ano e sete meses de atendimento, Thiago com cinco anos e onze meses)

Thiago, aqui, está conseguindo contar o que aconteceu e o que sentiu. E ao repetir para mim que havia ficado muito bravo com a minha ausência, mostrou para mim que qualquer que fosse meu entendimento (que foi porque eu fui viajar, mas já tinha voltado), isso não o impediu de ficar bravo! Além de conseguir contar o que sentiu, Thi conseguia, de fato, sentir e saber de si.

Escrever a palavra "bravo" foi só mais uma forma de elaborar, sem anular o sentimento. Ele sentiu no passado, e agora pôde fazer as pazes.

Cena 32

(...) $\mathrm{Na}$ aula de música a professora estava falando para a turma sobre pulsação, e pediu para a Elis ouvir o coração do Thi, e disse: "Veja se faz ti-ti, ti-ti". Elis ouviu e 
disse que sim, fazia. Depois, foi a vez do Thi ouvir o coração da Elis. Quando ele terminou, a professora perguntou: "O que vc ouviu, Thiago?", e ele respondeu "ElisElis, Elis-Elis". (Anotações pessoais, um ano e sete meses de atendimento, Thiago com cinco anos e onze meses)

Essa cena nos mostra que Thiago entendeu que o que bate dentro do peito é o nome da pessoa. Ele fez uma criação e descrição da experiência de forma conjunta. Quem vai negar que esta invenção tem um acerto pontual no alvo da realidade?!

Cena 33

(...) O professor leu para a turma a nova história que fiz do Breno para o Thiago, que se chama "Breno e a escola de vôo - Parte 1". Foi muito bacana! Cada criança começou a falar, na roda, para qual escola iria, e eu ajudei o Thi com o nome da escola para onde ele vai.

Depois, o professor sugeriu para eles fazerem um desenho sobre algo que imaginavam sobre a escola nova. As crianças, espontaneamente, se desenharam como pássaros, assim como os do livro. Thi desenhou apenas o Breno e pareceu não gostar muito da ideia de mudar de escola... Ainda bem que ainda temos tempo para ajudá-lo a elaborar essa mudança! (Anotações pessoais, um ano e sete meses de atendimento, Thiago com cinco anos e onze meses)

Thiago identificado com o Breno, podemos dizer que ele se desenhou... mas solicitar o contexto, que talvez para ele ainda não fosse claro e definido, deve ter sido uma exigência além do que lhe era possível naquele momento. E, pelo visto, tudo bem. Ainda haveria tempo de elaborar essa mudança!

Cena 34 - Cena final: "Luisa, conta a história!”

A Giulia é uma criança da turma dele, que recentemente começou a se aproximar de nós no parque para brincar junto. Em uma sexta-feira, quando estávamos brincando na casa da árvore, encontramos com ela. A princípio eu estava narrando a história do peixe e da estrela do mar (moldes para brincar na areia) que o Thiago estava segurando e mexendo, de um lado para o outro. A Giulia estava em uma parte que tem cordas, brincando de fazer túnel e escalar. Em um momento, Thiago sentou bem próximo do lugar em que ela estava, e ficou observando. Eu sugeri que ele passasse por baixo das pernas dela, dizendo que era uma ponte, e que os personagens poderiam passar também. Ele ficou animado com a idéia e passou uma vez. Logo em seguida, passou outra. Sorria e ria ao fazer isso. Eu, do outro lado da ponte, vibrava com a interação entre eles. E então, a Giulia confiando que o amigo seria capaz, disse "Thiago, agora você!". Fiquei esperando para ver o que ele iria fazer. Ele olhou para mim e eu o encorajei "Vai lá, Thi, faz você a ponte, agora!", e ele foi. Ela continuou a ordem "Você fica aqui no meu lugar e faz ponte, eu vou passar embaixo!". Ele, sem titubear, foi. Fez a ponte. Ela passou embaixo. Eu falei "Muito bem, Thi, você conseguiu!!!", ele repetiu "Muito bem, você conseguiu!" e nós três demos risada. Era como se todos ali soubéssemos da dificuldade dele, e estivéssemos felizes pela conquista.

$\mathrm{Na}$ segunda-feira seguinte, assim que chegamos ao parque de areia, ele correu para pegar o peixe e a estrela do mar. Não os encontrou na caixa, e falou triste para mim "o senhor peixe e a estrela do mar não vieram". Procurei com ele mais um pouco, e na falta dos personagens, sugeri brincarmos sem eles naquele dia. Um pouco desapontado, ele aceitou e me levou pela mão para a casa na árvore. 
Chegando lá, encontramos a Giu, que estava novamente brincando de ponte. Thiago não demorou para passar por baixo dela, e dar risada. Ela pediu para eu passar também, e para isso falei que o Thiago deveria fazer uma outra ponte, que passaria nas duas. Os dois ficaram bem animados, e com um pouco de esforço, eu passei. Em seguida, Thiago quis passar de novo, e ao chegar do outro lado, imitou que estava chorando. Eu logo perguntei "O que aconteceu?" e a Giu respondeu "Ele faz isso às vezes, mas não é nada.”. Fui até onde ele estava, perguntei o que tinha acontecido e ele não respondeu. Perguntei, então, se ele tinha se machucado ou se era só manha, e ele respondeu "só manha", e nós três demos risada. Depois disso, Giulia não continuou a brincadeira, desceu para a areia e nós ficamos lá. Eu fiz a ponte, então, para ele passar embaixo, e também foi divertido, embora minhas pernas fossem maiores e ele nem precisasse se abaixar muito para passar...

Pouco tempo depois, a Giulia voltou com a sua boneca. Pediu para eu segurar e disse que iria buscar dois bolos (feitos de areia, mas com sabor de chocolate). Mal ela se virou e o Thiago quis pegar a boneca. Dei para ele, e ele segurou com muito cuidado e carinho. Colocou a boneca deitada em seu colo, balançou, e falou que estava segurando a bebê. Ficou olhando da cabeça até o pézinho, passando pela chupeta e pelo vestido, tudo com muita atenção. Logo chegou a amiga com dois baldes de areia, eram os bolos. Ela disse que era um para mim e outro para o Thi, e que era para nós cantarmos parabéns. Pedi que o Thiago perguntasse para a Giu o nome da bebê, ele perguntou, e ela respondeu: "Vitória". Ele repetiu o nome, colocou a boneca nas cordas, balançou um pouco e pegou novamente no colo. A Giu sugeriu que nós déssemos a mamadeira, pois a bebê estava com fome. Pediu para o Thiago a Vitória, para ela dar a mamadeira. O Thiago deu, e ficou olhando ela segurando e dando a mamadeira (de faz de conta, sem nenhum objeto substituto). Assim que terminou, ela devolveu a Vitória para os braços de Thiago, que continuou embalando-a. Thiago, repentinamente, colocou a bebê encostada em mim, me deu um beijo, e falou "Eu dei um beijo na Lu!", e saiu. Voltou, logo em seguida, com uma folha, e disse que seria a vela do bolo. Giulia, nesse momento, se desinteressou um pouco da brincadeira, disse que iria descer para a areia, e pediu para nós cuidarmos da Vitória. Nesse momento, Thiago pegou a bebê e falou "Luisa, conta a história do Thi, da bebê e da Luisa?".

Não cheguei a narrar a história, como sempre faço quando ele me pede. Julguei, naquela hora, que o mais importante era a pergunta, e não a resposta. Ele não voltou a pedir, e logo descemos para brincar na areia também.

Estávamos no meio da brincadeira, quando ele se jogou no chão e começou a forçar um som de choro. Isso tem acontecido, ultimamente, quando quer que eu vá até ele. Seu professor, vendo a cena, falou "Thi, levanta e pára com isso. Se você quiser, você chama a Luisa", e enquanto ele falava, fui me aproximando do Thiago, e percebi que ele não estava parando de chorar, como costuma acontecer quando ele só quer que eu fique perto. Então, parei ao lado dele, sentei no chão, ele veio para o meu colo, e disse “Thi, o que está acontecendo?" e eu falei “É, o que está acontecendo, Thi? Você estava chorando no chão igual a um bebê, o bebê da Giulia..." ele, com os olhos atentos a mim, parou de chorar e continuou me olhando, o que eu entendi como uma permissão para continuar dizendo. "Você já foi um bebê, sabia? Igual ao da Giulia. Você não falava, chupava chupeta, tomava leite na mamadeira, usava fralda... Mas aí você foi crescendo, parando de fazer essas coisas, e foi virando um menino, uma criança, que é o que você é hoje." Ele continuava muito atento a mim. Perguntei "você fez isso porque você queria ser um bebê de novo?" e ele respondeu de imediato "queria ser um bebê de novo...". Segurei ele firme no colo, abracei, disse que ele poderia ser um bebê de novo, ali, naquele exato momento, e depois disse "agora, você pode voltar a ser o Thi, a criança, o menino grande, que sabe falar e fazer um montão de coisas. Vamos?" e ele se levantou do meu colo, eu me levantei do chão, ele segurou minha mão e nós fomos brincar de ponte na casa da árvore. (Anotações pessoais, um ano e sete meses de atendimento, Thiago com cinco anos e onze meses)

\section{Esta descrição em cena é extensa. Diz por si mesma. Mas, talvez por conta do contexto}

da tese, ainda nos caiba tecer alguns comentários. Vamos a eles: logo no início, temos já de 
partida nossos lugares garantidos: eu e Thiago brincamos; mais adiante, Thiago expressa sua vontade e a existência própria dos personagens que costumava brincar (o senhor peixe e a estrela do mar); em seguida, quando Giu responde a mim dizendo que às vezes Thiago chora e não é nada, ela está sendo também uma intérprete dele!; quando Thi diz que me deu um beijo, ele está contando e está usando o pronome pessoal em primeira pessoa para dizer de si. Mais ao final, quando Thiago pergunta, em teceira pessoa o que está acontecendo, parece perguntar como quem quer que lhe seja perguntado. Eu efetivamente faço a pergunta a ele, e ensaio uma resposta por palavras que circulam e fazem girar o discurso, descrevendo como ele estava (chorando) e fazendo uma história de sentidos ("chorando igual a um bebê, o bebê da Giulia). Eu conto a história que ele tinha me pedido antes, a história do Thi, do bebê e da Luisa. Quando eu pergunto se ele agiu dessa maneira porque queria ser um bebê de novo e ele confirma, eu entro na história, faço com que o enredo se realize e em seguida puxo para o contexto concreto. E em confiança, ele atende...

É interessante pensar sobre essas cenas, sobre o percurso terapêutico dele, e sobre seu processo na vida.

Ao chegar no consultório, pela primeira vez, ele era visualmente um menino de 4 anos. Passada a primeira meia hora, ele virou um bebê deitado no chão da sala aguardando a mãe trocar a fralda, e passada mais meia hora ele novamente virou um bebê ao deitar no sofá da sala com seu travesseirinho inseparável para tomar a mamadeira de suco. E então, começamos a terapia, ele começou a se comunicar melhor, falar frases de duas palavras. Seis meses depois, além de se comunicar melhor, começou a retirada da fralda, até ficar sem. E menos de seis meses depois da fralda, começou a tomar água e suco no copo, até ficar sem a mamadeira. $\mathrm{O}$ Thiago cresceu. Ele se transformou. Atravessou a ponte dos bebês para as crianças. E, com certeza, essa não foi uma tarefa fácil. Que bom que ele conseguiu dizer e sentir que pode atravessá-la de volta, imaginariamente, por alguns instantes, mesmo que breves.

\subsubsection{Lola: acaso e acontecimento como discurso}

Todo o atendimento de Lola foi realizado por nós com a AID. Na ocasião, já tínhamos também a certificação da escala ADOS. Esta foi aplicada no início e ao longo do trabalho clínico com ela.

\subsubsection{Breve histórico}


Lola nasceu de uma gestação múltipla, de trigêmeos, e seus pais já tinham um outro filho, de um ano e sete meses, quando ela e seus outros dois irmãos (um menino e uma menina) nasceram.

Conforme o relato dos pais (pai é médico e a mãe enfermeira), dos três bebês, inicialmente (até os quatro meses), ela era a mais apática. Chegaram a comentar essa percepção com o pediatra, que na ocasião atribuiu ao fato de ela ter ocupado posição superior na gestação, recebendo menor estimulação da contração intrauterina. Entre os quatro e dez meses, Lola passou a chamar a atenção dos pais sobre o quanto ela era sorridente. Mas, a partir dos dez meses eles perceberam que ela começou a se esquivar do contato visual e observaram que não atendia mais aos comandos, não respondia ao ser chamada pelo nome, por exemplo, e no aniversário de um ano, chorou durante toda a festa.

Os pais relataram, também, que Lola sempre teve um desenvolvimento um pouco mais lento quando comparado ao de seus irmãos, algo em torno de dois meses de diferença. Descreveram-na como sendo sempre a mais boazinha, que brincava sozinha em casa e na escola, mas que demonstrava muita irritação com as mudanças de rotina.

Lola e seus irmãos entraram na escola com um ano e quatro meses. Com um ano e seis meses ela apresentou desmaio repentino e de curta duração na escola, que não foi investigado pela família por se tratar, segundo eles, de um evento isolado.

Quando estava com um ano e dez meses, um amigo da família, também médico, levantou a suspeita de TEA e fez indicação de uma nutróloga para acompanhar a pequena, que também apresentava quadro de refluxo, cólicas e intolerância à proteína do leite. Esta médica confirmou a suspeita de TEA, fez a indicação de nossa equipe para avaliar Lola e dar início ao atendimento em psicoterapia e também a encaminhou para um trabalho de fonoaudiologia.

A primeira avaliação de Lola foi quando ela estava com dois anos e dois meses. Iniciamos, em seguida, os atendimentos. A princípio foram realizados no consultório, duas vezes na semana, por três meses. Por conta da distância e do trânsito que Lola e sua mãe pegavam para chegar ao consultório, no ano seguinte, passamos a atendê-la em sua residência, cada sessão com duas horas de duração, em um quarto destinado para a psicoterapia.

Seis meses após o atendimento em casa, devido a uma mudança de escola, quando ela estava com três anos, passamos a acompanhá-la também no âmbito escolar, três vezes na semana. Seguimos assim até os cinco anos e cinco meses de Lola, quando reduzimos o acompanhamento escolar para duas vezes na semana, e mantivemos as sessões em casa também duas vezes na semana. 
Lola iniciou a fonoterapia aos dois anos e três meses, e com esta mesma idade começou as aulas de musicoterapia. Ela permaneceu nestes dois atendimentos por seis meses, e após esse tempo, por conta de a família não ver progressos na fala, as sessões de fonoaudiologia foram interrompidas, e as aulas de musicaterapia foram suspensas por conta da logística familiar.

Lola e sua família tiveram certa dificuldade em encontrar profissionais da área de fonoaudiologia, por questões diversas, sendo as principais: incompatibilidade de agenda, e não aceitação de Lola ao profissional (chorava muito ou ficava apática).

Quando Lola estava com dois anos e oito meses, a partir de algumas brincadeiras com sons de animais, suspeitei que talvez ela pudesse ter apraxia de fala. Conversei com a médica nutróloga que a acompanhava, e ela recomendou uma fonoaudióloga especialista nesta dificuldade. A mãe de Lola não conseguia horário com essas especialistas para avaliar a menina. Quando Lola estava com três anos e três meses eu fiz um curso da Associação Brasileira de Apraxia, conversei com a fonoaudióloga precursora desse trabalho no Brasil, e acertamos uma avaliação para Lola.

Com três anos e cinco meses Lola teve o diagnóstico de apraxia de fala, tivemos indicação de uma fonoaudióloga especializada na área que poderia desenvolver esse trabalho com ela e, assim, passou a fazer, duas sessões na semana (a princípio no consultório, e depois em casa). Com cinco anos e cinco meses Lola teve seu atendimento reduzido para uma vez por semana por conta dos progressos conquistados em relação à pronúncia e dicção de fonemas, bem como linguagem expressiva.

O tratamento com a nutróloga foi suspenso pela família quando Lola estava com três anos e meio.

Aos três anos e dois meses Lola fez uma avalição em terapia ocupacional, por conta de algumas sensibilidades auditivas e táteis, bem como tônus baixo para a idade, mas a família não conseguiu dar prosseguimento ao trabalho.

Dos três anos e oito aos quatro anos e quatro meses, Lola fez um programa com músicas clássicas para reduzir a sensibilidade auditiva (The Listening Program ${ }^{41}$ ), voltado para pessoas no TEA. O programa teve início em um momento em que ela estava se desorganizando muito, principalmente na escola, com os barulhos dos colegas de turma, bem como os ruídos dos ambientes. Ela começava a chorar, tinha dificuldade em se acalmar, tentava se morder e se bater. O programa foi bem efetivo neste sentido, pois ela passou a tolerar mais a permanência

\footnotetext{
${ }^{41}$ The Listening Program $®$ é um programa criado pela Advanced Brain Technologies $®$, empresa norte-americana, que auxilia no processamento auditivo por meio de gravações de músicas clássicas em que cada instrumento é gravado em um canal e frequência diferentes, estimulando diferentes áreas do cérebro.
} 
nesses ambientes, mesmo com o barulho, sem que chorasse ou tivesse comportamentos autoagressivos.

\subsubsection{Sobre o desenvolvimento de Lola durante o atendimento}

Conhecemos Lola na primeira avaliação com a ADOS, quando ela estava com dois anos e dois meses. No colo da mãe, ao chegar, uma bebê! Depois, na sala, olhava para tudo mas desviava o olhar das pessoas. De cabelos castanho claro e cachinhos, andava como que para reconhecer o espaço, escolhendo com o que iria brincar. Tudo isso de um jeito lento, como quem segue seu próprio tempo. Essa era Lola.

Por conta de idade naquele momento (menor de 31 meses), a avaliação indicou apenas o risco de autismo, e não o grau de sintomas associados.

Lola, naquela ocasião, não fez uso de palavras ou aproximações de palavras, apenas vocalizou algumas sílabas. E, embora o fizesse direcionando em alguns momentos para mim e para sua mãe (que a acompanhou durante toda a avaliação) vocalizou com maior frequência para os objetos com os quais estava brincando.

Ela fez uso da mão da mãe e também da minha para pedir ajuda sem coordenar com o contato visual. Não apontou com o dedo indicador, e fez uso de apenas um gesto, o de "tchau" com a mão.

Ela quase não fez contato visual, e quando o fez, não conseguiu integrá-lo a outros comportamentos, como vocalização e/ou gesto. Respondeu ao nome voltando-se para a mãe quando esta a chamou pela terceira vez, mas não conseguiu seguir meu olhar como pista para um objeto distante, ou mesmo meu apontar para este objeto indicando resposta a um momento de atenção compartilhada. De maneira geral, ela demonstrou pouca abertura e resposta social.

Em relação às brincadeiras, mostrou prazer com os brinquedos de causa-efeito, fez uso no telefone de miniatura de forma espontânea, mas não conseguiu imitar ou reproduzir brincadeiras com outros objetos representacionais.

Não apresentou interesse sensorial incomum pelos materiais apresentados, nem comportamentos disruptivos, de autoagressão, de autoestimulação, movimentos repetitivos de tronco, braços ou mãos, ansiedade, agressividade.

A avaliação indicou risco moderado a elevado para desenvolvimento de TEA.

Dois meses após o início da terapia, Lola já estava usando o dedo indicador para apontar objetos fora de seu alcance, batendo palmas e fazendo gestos simples relacionados a músicas. 
Além disso, seu contato visual estava com uma frequência e duração maiores do que na ocasião da avaliação, e em alguns poucos momentos, estava conseguindo vocalizar e olhar ao mesmo tempo.

Após onze meses de atendimento, quando Lola estava com três anos e um mês, em uma nova avaliação com a ADOS (solicitada pelos pais), ela continuava sem fazer uso de palavras, apenas vocalizações de sílabas, e direcionando, ainda, a maioria de suas vocalizações aos objetos aos quais estava brincando. Entretanto, já estava fazendo uso de gestos comunicativos, e outros, como o "não" balançando a cabeça, assoprando, cheirando, apontando com o dedo indicador, e integrando em alguns momentos o gesto ao contato visual.

Em uma hora de avaliação, Lola fez contato visual para iniciar, regular ou finalizar interações sociais, mas não de modo integrado a vocalizações ou gestos. Ela respondeu ao nome na primeira vez em que foi chamada por mim, de forma imediata.

Deu objetos para mim e para a mãe de forma espontânea e mostrou objetos, mas sempre com o propósito de pedir ajuda, não de compartilhar interesse. Ela conseguiu acompanhar com o olhar o meu apontar a um objeto distante, respondendo a um momento de atenção compartilhada. Ela fez mais tentativas de iniciar momentos de atenção compartilhada, e em suas aberturas sociais demonstrou sempre alguma tentativa de envolver a mim e/ou a mãe.

Em relação ao brincar, Lola interessou-se por diferentes brinquedos, incluindo miniaturas de objetos cotidianos como copo e jarra. Fez brincadeira espontânea usando a boneca como agente independente, mas não chegou a fazer uso de um objeto para representar outro.

Sua pontuação nesta avaliação indicou quadro de TEA, em nível baixo de sintomas associados.

Um mês antes desta última avaliação de Lola, eu iniciei o acompanhamento terapêutico dela em sua nova escola, três vezes na semana, três horas por dia. Além de a mudança de escola por si só já ser ocasião de novos desafios para uma pequena que resistia a ter sua rotina alterada, por questões de mudanças nas medicações e suplementações, aquele semestre foi especificamente difícil para Lola. Ela ficou bastante irritada na escola, e por vezes chorou e tentou se autoagredir em diversas ocasiões.

No ano seguinte, partindo do interesse de Lola (agora com três anos e cinco meses) por livros, e por tê-la ensinado ocasionalmente, durante uma brincadeira, a ler as vogais, começamos um processo de alfabetização em paralelo ao da escola. Naquele momento Lola parecia entender tudo o que lhe era dito, mas faltava-lhe recurso para dizer também. Por conta disso, considerei importante que ela tivesse alguma forma de comunicação, mesmo que fosse 
pela leitura/escrita. Conversei com a família e com a escola, e demos início a esse trabalho específico. A terapia passou a ter a alfabetização como pano de fundo, em que as atividades e brincadeiras propostas usavam este foco de interesse da menina para aprender tanto sobre as letras, como sobre a comunicação e a interação.

Ao final daquele ano, Lola com quatro anos e quatro meses, estava alfabetizada. Além disso, já estava conseguindo falar algumas palavras e repetir pequenas frases! Sim! Podemos dizer que ela começou a falar, lendo e escrevendo (formando palavras com letras móveis).

$\mathrm{Na}$ escola, Lola encontrava o nome dos amigos nos painéis da sala, compreendia comandos, fazia todas as atividades da turma. As crianças de seu grupo ficavam impressionadas de ouvirem sua voz, bem baixinha, vez ou outra. E eu seguia, ao seu lado, naqueles três dias da semana, dando suporte emocional e de atenção constantes. Conversando com a professora, programando momentos de maior interação entre ela e os colegas, seguimos ajudando Lola a se regular em alguns momentos em que se desorganizava por conta do barulho, por não ter suas expectativas correspondidas, por sentir algum desconforto físico que não conseguia nos comunicar (dor de barriga, por exemplo, que ela tinha com certa frequência), ou quando era interrompida em alguma atividade que gostava muito.

Este também foi o ano em que Lola deixou de usar fralda por definitivo, após uma tentativa traumática (vide cena) na escola!

No início do ano seguinte, quando Lola estava com quatro anos e cinco meses, e nós já estávamos a atendendo há dois anos e quatro meses, fizemos uma nova ADOS em que a pontuação dela reduziu, mas permaneceu no TEA com sintomas relacionados ao nível baixo. Entretanto, nesta avaliação, tínhamos uma nova menina! Uma menina que fazia uso de palavras simples, que direcionava sua fala para as pessoas do ambiente em que estava, que fazia uso de gestos integrados com o contato visual, que apontava, que dirigia expressões faciais diferentes em contextos adequados, que dava objetos para compartilhar, e seguia meu olhar e apontar como resposta a um momento de atenção compartilhada.

Ainda tínhamos trabalho pela frente, como a integração do olhar à fala principalmente durante as aberturas sociais, que suas aberturas sociais não fossem restritas aos seus interesses e demandas, brincar fazendo de conta que um objeto era outro, e mostrar objetos fora de alcance sem a intenção de pedir ajuda.

Naquele ano, o acompanhamento escolar se manteve por três dias na semana mais por conta da escola do que propriamente de Lola. Sua sala passou de dez alunos para vinte e um, o que fez com que a professora conseguisse dar menos atenção e mediasse menos as brincadeiras 
das crianças, tornando minha presença fundamental nesses momentos. Apesar de pedagogicamente Lola acompanhar a turma, sem precisar de adaptação, ainda precisava de um olhar específico para ela em determinadas situações, como: ensiná-la a segurar corretamente o lápis e lembrá-la de como fazer isso a cada atividade; auxiliá-la na interação com os colegas, pois dificilmente tinha a iniciativa, e as crianças também não a procuravam como parceira de brincadeira; a permanecer na roda mesmo quando a professora tinha que interromper para dar bronca em alguma criança, ou demorava mais para dizer o que iria ser feito pela turma; a aguardar sua vez em uma brincadeira coletiva e respeitar a vez dos amigos; entre outras.

Em terapia fizemos muitos jogos que trabalhavam a alternância de vez e cooperação, a construção de pequenas histórias e personagens, brincadeiras imaginativas com objetos representativos e não representativos, brincadeiras de perguntas e respostas, de interpretação de texto e expressão facial, de construção de frases em contextos.

E o acompanhamento todo segue. Assim como a parceria com os pais e os irmãos dela, que são, antes de tudo, amorosos e compreensivos com a Lola.

\subsubsection{Cenas}

\section{Cena 1}

(...) A Lola sentou na mesinha para brincar com os carimbos e quando fez o do porco, eu fiz o som "oinc", e ela deu risada. Carimbou várias vezes esse, e eu fiz o som em todas. Em dado momento, reparei que ela começou a vocalizar "a, a, a", no mesmo ritmo em que fazia "oinc, oinc, oinc". Percebi que sempre que eu fazia o som ela me olhava. (Anotações pessoais, dois meses de atendimento, Lola com dois anos e três meses)

\section{Cena 2}

(...) É interessante perceber que Lola, em pouco tempo de terapia, já espera que eu ou sua mãe possamos interagir com ela de alguma forma, com o jogo de encaixe dos peixinhos. No começo, enquanto ela colocava cada peixinho na sua cor, eu dizia que também iria colocar um, dizia a cor e colocava, ela parecia não me notar. Em quatro sessões, mais ou menos, brincando dessa forma, quando eu ou sua mãe não colocávamos nenhum peixinho e ela se dava conta disso, ela parava de encaixar os demais e nos olhava brevemente, como quem diz "vocês não vão encaixar?". Nós, então, fazíamos algum encaixe e ela seguia com os dela. Ela encaixava nas cores certas, sabia como funcionava o brinquedo, podia brincar sozinha se quisesse, mas ainda assim esperava por nosso contato e interação. (Anotações pessoais, três meses de atendimento, Lola com dois anos e quatro meses) 
É interessante notar que na Cena 1 Lola reage quando eu faço algo, e na Cena 2 ela reage quando eu deixo de fazer/não faço algo. Com essas cenas nós conseguimos perceber que Lola já apresentava uma atenção às pessoas e ao ambiente desde o início, por mais que tivesse dificuldade em se comunicar e de interagir como crianças de sua idade.

Nota-se aqui a correspondência de atenção que começa a fazer. Isto porque também é evidente a sua atenção a qualquer variação de movimentos dela ("oinc, oinc”, "a, a").

\section{Cena 3}

(...) A Maria, babá da Lola, me contou que ela gosta muito do desenho da Peppa Pig, e que por vezes ela tenta imitar algum gesto. Então, eu pedi para a mãe dela algumas fotos dela fazendo coisas que a Peppa faz no desenho, como ir para a escola, usar roupa de frio, comer com os irmãos, enfim. Na descrição de cada imagem eu coloquei "A Peppa vai para a escola..." e na outra página, "A Lola também vai para a escola!", porque assim qualquer pessoa da casa dela pode ler o livro da mesma forma, fazendo esse paralelo entre a Peppa e a Lola. Hoje eu apresentei o livro para ela, e ela gostou muito. Ela sorria, olhava as imagens com muita atenção, e foi uma ocasião muito bacana de eu solicitar dela alguns pequenos gestos, com base nas imagens, como colocar a mão na cabeça para indicar o gorro nos dias de frio, por exemplo. (Anotações pessoais, cinco meses de atendimento, Lola com dois anos e seis meses)

Os acasos dirigem para um "rumo" que é o da organização da sua comunicação no e com o mundo. Muitos aspectos foram desenvolvidos aqui: interesse por personagens, maioria de suas atividades diárias protagonizadas agora por ela e pela personagem, num veículo que receberia muita atenção dela, um livro!

Cena 4

(...) Estavamos brincando de eu desenhar coisas com a cor da caneta que ela escolhia
e me dava quando fomos interrompidas pela mamadeira de suco. Quando ela terminou
de tomar, olhou pra mim, pegou uma caneta verde, me deu, e começou a vocalizar
bastante. Era como se fosse uma conversa. Eu não entendi muita coisa, então,
aproveitei a cor verde, os vários "a" que ela falou, e disse que faria uma árvore.
Desenhei, ela me acompanhou com o olhar atentamente, e quando eu terminei, falei
para ela que a árvore do desenho era igual a árvore lá de fora (que dava pra ver pela
janela da varanda). No que eu falei, apontei com o braço todo e dedo indicador e, na
mesma hora, ela acompanhou meu direcionamento e olhou para árvore. Eu fiquei
muito feliz com essa pequena conquista dela. Ela estava acompanhando meu gesto,
meu apontar. Tivemos, ali, um claro exemplo de comunicação, interação, e atenção
compartilhada! (Anotações pessoais, sete meses de atendimento, Lola com dois anos
e oito meses)

Temos aqui, desde o início, uma cena de ação compartilhada, em que Lola desencadeia o fazer da terapeuta escolhendo (cores das canetas) os disparadores. Tão compartilhada que a terapeuta fala da brincadeira pelo "nós". Ao assim "desentender" quem era o sujeito da ação, 
novamente atribui à parceira de sessão a condição de sugerir uma ação e, com ela, em retorno, sentiu-se acompanhada. É a sintonia tecendo todos os sentidos da cena.

\title{
Cena 5
}

\begin{abstract}
Hoje aconteceu algo muito incrível na sessão da Lola! Nós estávamos brincando de eu desenhar um animal, e ela tentar imitar o som. Eu desenhava o bicho, escrevia embaixo dele o som, fazia eu mesma o som com a minha voz, e ela ia tentando, do jeito dela, fazer o som, após eu dar o modelo. Fizemos os animais da fazenda, depois os da selva. Nós estávamos sentadas no chão, as canetinhas estavam ao lado do caderno, e ela me dava uma de cada vez para eu desenhar o animal e nós fazermos o som. Após cada som, eu perguntava se ela queria mais, e ela me dava uma caneta como permissão e pedido para que eu continuasse. Bom, chegou uma hora que meu repertório de animais já tinha chegado ao fim... eu falei para ela que não conseguia pensar em mais nenhum outro animal, e que nós já tínhamos feito muitos... Sugeri de trocarmos de brincadeira pegando as miniaturas, mas ela deu um grito, e rapidamente me deu outra caneta. Disse para ela que havia entendido que ela queria continuar na brincadeira, mas disse também que eu já não sabia mais qual animal desenhar. Aí, meio que numa tentativa, sem pretensão nenhuma de dar certo, eu falei para ela que iria desenhar para ela algo diferente, que não eram animais, mas que também fazia sons. Ela ficou me olhando... Então, eu desenhei a letra A no caderno, e disse "Lola, essa é a letra A. O som dela é assim "aaaaaaa". Na hora ela tentou imitar. Fiquei animada, e então apresentei todas as outras vogais. Ela tentou imitar, dentro de suas possibilidades, todas. Ao final, eu falei pra ela "Cadê a letra A?" e ela apontou corretamente. Perguntei, na sequência (A,E,I,O,U), as demais vogais, e ela apontou em todas, direitinho! Eu fiquei muito emocionada. Disse a ela que ela poderia não saber, mas estava aprendendo a ler, e que esse era um passo muito importante! Ela continuou me dando canetas. Então, eu virei a folha e escrevi as vogais fora da ordem, e nós falamos os sons. Perguntei, fora da ordem onde estava cada uma, e ela novamente acertou. Depois, em outra folha, escrevi as vogais misturadas, com mais de uma de cada, e falei que a brincadeira era encontrar o A. Ela colocou a mãozinha em todos!!! Foi muito bacana. Ela é mesmo incrível! (Anotações pessoais, sete meses de atendimento, Lola com dois anos e oito meses)
\end{abstract}

Temos aqui, logo de início, a nítida responsividade de Lola para chamar os bichos pelos sons que esses fazem. Em seguida, temos o compartilhamento da ação de fazer a sessão acontecer: Lola é uma auxiliar nos procedimentos que levam à sua aprendizagem. Neste trabalho todo, tudo poderia transcorrer no silêncio, não fossem os sons emparelhados à forma desenhada.

Quando a terapeuta pergunta se Lola queria que ela desenhasse mais e ela dá uma caneta como solitacitação de que a terapeuta continuasse, vemos aí o sentido de um gesto orientar a ação da terapeuta para dar prosseguimento na atividade. Ela não precisou falar com palavras; seu gesto também é uma forma de expressão, também é discurso.

Mais à frente, no texto, vemos que o acidental e o acaso é que movem o discurso da sessão. A falta de ideia da terapeuta no campo dos bichos é o que move para o campo das letras. Veja-se o sentido e a expectativa que esta gera em sua interlocutora ao colocar a letra no lugar dos animais. Afinal, a letra foi "animada" a produzir som... Tem-se, então, a compreensão 
imediata desse sentido compartilhado e a extensão para a classe das vogais (letras), da capacidade de produzir sons.

Essa cena nos mostra como a terapeuta se deixa guiar pelos desafios do procedimento de uma sessão para disparar sentidos e descobertas.

\section{Cena 6}

Hoje pela primeira vez eu vi Lola ficar triste por ter percebido que tinha errado algo. Ela tentou encaixar duas peças no brinquedo de encaixe que estávamos usando, e embora parecessem estar no lugar certo, não estavam. De alguma forma ela percebeu, e começou a chorar. Eu disse para ela que estava tudo bem, que ela tinha percebido que não estava no lugar certo, mas que eu poderia ajudá-la, e mostrei. Em seguida ela ficou ainda mais brava. Chorou, gritou, deitou no chão. Nós vimos na caixa, então, o modelo. Tivemos ali uma confirmação externa a mim e a ela. Ela voltou a chorar. Eu a consolei, dizendo que entendia sua tristeza, mas que às vezes nós íamos mesmo errar, e não tinha problema nenhum nisso, pois poderíamos tentar outra vez, em outro momento. Ela se acalmou. Por ser a primeira vez que vi nitidamente que ela estava chateada por errar algo, achei que tudo o que tínhamos vivido até ali tinha sido suficiente. Disse para ela que iria guardar o jogo, e que outra hora poderíamos brincar de novo, e ela não ofereceu resistência. (Anotações pessoais, dez meses de atendimento, Lola com dois anos e onze meses)

Novamente temos uma busca de sentidos por parte da terapeuta, mas agora para a tristeza como efeito da relação de Lola com seu próprio erro. O sentido atribuído foi muito colado à situação (razão de uma possível dor dicente do erro), e foi descrito pela terapeuta como "consolo", indicando a finalidade que atribui ao próprio ato de colocar palavras para redirecionar ou diminuir o sofrimento de Lola.

Cena 7

No meu primeiro dia de acompanhamento da Lola na escola, quando sua turma saiu do refeitório e foi escovar os dentes, a Lola passou pelo corredor do banheiro e começou a chorar. Ela não queria ir para o banheiro. Na verdade, não sei nem se ela tinha entendido que ali era o caminho do banheiro e que ela iria escovar os dentes, ou se tinha entendido e queria ir para outro lugar. Sei que ela começou a chorar, indo no fluxo contrário, e quando eu agachei em sua frente, para conversar com ela e, no mesmo movimento impedi sua passagem, ela começou a se morder, sentou e foi direto com a cabeça no chão para bater. Eu a segurei firme em um abraço e disse que ela poderia ficar muito brava e contrariada, mas que não podia se machucar. Ela ainda tentou se desvencilhar, ainda chorando e como quem iria continuar a se bater, e eu disse que a soltaria assim que sentisse que ela não iria se machucar. Levantei com ela no colo, e disse que ela ia se acalmar comigo, porque sozinha ela não estava conseguindo. Tudo isso no corredor, sem sair do lugar. Ficamos um pouco ali, assim, ela se acalmou, eu a coloquei no chão, e seguimos para o banheiro.

Ao voltar para a sala, contei para a professora o que havia acontecido e como eu tinha agido, e pedi que na minha ausência a mesma conduta fosse feita, para que Lola pudesse se sentir segura em sua braveza, mas sem fisicamente se machucar. (Anotações pessoais, onze meses de atendimento, Lola com três anos) 
Logo na primeira frase temos dois sujeitos que se configuram numa ação paritária de apropriação do fazer na escola: o primeiro dia de acompanhamento aparece como "meu", partilhado também como o de Lola; mas Lola já era aluna antes de iniciar o acompanhamento feito pela terapeuta.

É essa sensação de atravessamento de uma realidade compartilhada que enfrentamos nas primeiras cenas de contrariedade e seus efeitos sobre Lola. Contundências à parte, impedimentos externos são seguidos de auto-ataque, até que haja a colocação de limites a ele. E será a firmeza e proteção oferecidas pela terapeuta que têm efeito organizador para a pequena Lola. Em seguida, na orientação dada à professora, há também uma explicação. Com todos os elementos já colocados para a própria Lola!

\title{
Cena 8
}

\begin{abstract}
Hoje, pela primeira vez, a Lola usou as plaquinhas de comunicação que estavam com ela na bolsinha ${ }^{42}$, na escola! Nós estávamos no parque, quando ela sentou no chão e ficou olhando todas as plaquinhas, uma a uma, com muita atenção. Até que ela pegou a da massinha, segurou firme e me mostrou! Eu fiquei muito feliz, mas não tinha massinha naquele momento, ali no parque. Então, expliquei para ela que eu tinha entendido que ela queria a massinha, mas que no parque não tinha massinha, e disse que teríamos que pedir para a coordenadora pedagógica. Nisso a coordenadora passou por nós, e eu fui logo contando para ela o que havia acontecido. Enquanto eu contava, passou uma outra professora com uma caixa cheia de materiais dentro, e parou para falar com a coordenadora também. Na hora, Lola viu um grande pote de massinha na caixa, e tentou pegar. Eu pedi pra ela dizer para professora o que ela queria, antes de pegar, e ela apontou a imagem da massinha na plaquinha. Imediatamente a professora abriu e deu um pedaço para ela. Ela ficou MUITO feliz! Dava risada, batia palma, estava encantada com a possibilidade de ser compreendida e ter sua vontade atendida! (Anotações pessoais, um ano de atendimento, Lola com três anos e um mês)
\end{abstract}

O dispositivo de comunicação feito para Lola supunha essa autonomia dela em relação ao que gostaria de dizer para outras pessoas, e foi a partir dele que ela começou a portar sua comunicação com o mundo (de sentidos arbitrários, códigos, a que ela não conseguia ascender até muito recentemente). Mais pessoas poderiam entendê-la, agora, não só a psicóloga...

Nota-se aqui uma coerência quanto aos procedimentos e metas. Coerência, esta, estratégica para facilitar a enunciação.

\footnotetext{
${ }^{42}$ Faz-se necessário aqui contextualizar o leitor sobre esta bolsinha: Lola gostava muito de carregar coisas consigo, incluindo pequenas bolsas. Após confeccionar um chaveiro com algumas imagens que faziam referência a pessoas, objetos, lugares e ações de seu interesse, para que ela conseguisse com autonomia nos comunicar o que estava querendo e/ou precisando, confeccionei também uma bolsa pequena de colocar na cintura, para que suas mãos pudessem permanecer livres, para as atividades rotineiras, e que, ao mesmo tempo, ela pudesse recorrer às imagens para se expressar. Lola adorou, tanto o chaveiro como a bolsinha, e adorava "desfilar" com eles pelos lugares. Mas, até aquele momento, ainda não havia feito um uso funcional (para se comunicar/expressar) espontaneamente.
} 
Ao final da cena, temos a sinalização do prazer de Lola em desfrutar dessa autonomia conquistada para dizer de suas vontades: muita alegria!

Cena 9

\begin{abstract}
Hoje a mãe da Lola me contou por telefone que quando ela chegou em casa com as crianças, após a escola, ela pediu que as crianças tirassem os sapatos e fossem lavar as mãos com ela no banheiro, e depois, cada criança que saía com as mãos limpas, ia para o quarto de brincar, que tem uma grade na porta, como ela sempre faz. Mas hoje ela disse que foi diferente, pois ao colocar a Lola no quarto de brincar, ela reclamou! Ficava no portão tentando abrir e chorando. E a cada vez que via a mãe se aproximar, para levar outro irmão, ela se acalmava.

Eu percebi que a mãe de Lola estava um pouco apreensiva em sua fala, ela até chegou a dizer que ficava angustiada em ver a filha chorar. Eu conversei com ela e expliquei que embora fosse mesmo angustiante, era um bom sinal: Lola estava mais atenta ao ambiente e às pessoas ao seu redor. Ela estava pedindo a presença dos outros, coisa que antes parecia ser indiferente! E que o choro vem porque ela ainda não tem outros recursos para se comunicar, e ele acaba adquirindo muitas funções... (Anotações pessoais, um ano e um mês de atendimento, Lola com três anos e dois meses)
\end{abstract}

Não se trata de dizer apenas que Lola estava querendo atenção. É preciso ver quem é a Lola, qual sua história, seu histórico, em que contexto ela se encontra, e qual o sentido daquele choro específico, naquela situação. Há algo que para Lola é novo: notar a ausência da mãe e pedir sua presença como pode naquele momento: pelo choro.

\title{
Cena 10
}

\begin{abstract}
A sessão de hoje foi muito incrível. Estávamos na brincadeira de ela me dar uma canetinha, eu desenhar o animal, escrever o som dele, e nós imitarmos, quando desenhei um cachorro. Imediatamente fiz o som e Lola o repetiu. Então, na hora que fui escrever, fiz de forma bem pausada, mostrando para ela que era primeiro a letra A e depois a letra U. Então, pedi que ela lêsse o que estava escrito, e ela leu exatamente como eu escrevi, de forma pausada, "A, U”. Então eu falei que ela podia ler as duas letras juntas, "Au". Ela leu de novo "A, U”, então eu repeti dizendo que ela estava certa, eram as letras A e U, mas que juntas elas faziam uma palavra, a palavra "Au", que era o som do cachorro. E aí eu li "au, au”. E em seguida ela leu “A, U. Au, au!", ficou toda sorridente!

Eu fico muito impressionada com a atenção ao que faço e ensino a ela, e a compreensão que ela consegue ter disso tudo, mesmo sem ter uma fala que favoreça uma comunicação social, mesmo com todas as outras dificuldades de desenvolvimento que apresenta. Ela tem uma força de vontade, e uma capacidade, invejáveis. (Anotações pessoais, um ano e dois meses de atendimento, Lola com três anos e três meses)
\end{abstract}

O método é o da dupla que se sonda, se acrescenta e se move. E, novamente, temos a alegria de Lola ao perceber que ela entende como o mundo da comunicação se organiza.

A terapeuta deixa transparecer a admiração e a confiança nas possibilidades de comunicação, entendimento, presença e ligação de Lola. 


\section{Cena 11}

(...) Aí a Lola pegou o painel dos animais, colocou no chão e ficou olhando. Comecei, então, uma brincadeira de eu dizer o nome do animal e ela apontar no painel qual era e a fazer o som, conforme ela sabia/conseguia. Foi bacana porque até então a gente sempre brincava, comigo dizendo o nome do animal, ou mostrando, e ela fazendo. Agora, estamos com mais opções de brincadeiras. E ela se divertiu com essa variação! (Anotações pessoais, um ano e dois meses de atendimento, Lola com três anos e três meses)

Para a terapeuta, a relação com Lola amplia para ambas o caminho que têm à frente para brincar, e brincar, e brincar, cada vez de forma diferente.

\section{Cena 12}

(...) levei também o jogo Pula Pirata. Ao final da sessão ela pegou o jogo para brincar, e eu fui colocando as espadinhas no barril e dizendo que em algum momento o pirata iria pular. Dei algumas para ela me ajudar, fomos alternando a vez (quando possível), mas quando ele pulou, ela parou e ficou olhando... como que sem entender porque ele tinha pulado, se ela ainda tinha espadinhas para colocar, ou qualquer outra coisa que estivesse imaginando naquele momento. Então, eu repeti que o pirata poderia pular com qualquer espada que colocássemos, e disse que iria tirar as espadas para brincarmos de novo. Notei que quando fomos colocar novamente as espadas, ela empurrou minha mão. Eu falei para ela que ela havia empurrado minha mão, e que eu iria entender que ela não queria que eu brincasse com ela naquele momento. Ela olhou para mim e começou a colocar as espadas, sozinha. Eu aguardei. Quando o pirata pulou, ela mesma começou a tirar as espadas. Vi que ela iria colocar novamente, e disse que iria tentar brincar com ela dessa vez. Ela não me impediu e nem me afastou, e jogamos juntas.

Como a sessão já tinha chegado ao fim, eu avisei que iria chamar a irmã dela para jogar uma partida com a gente. Ela sorriu. A irmã veio, brincamos juntas, e ela deu risada quando o pirata pulou.

É interessante pensar no tempo da Lola. Ela precisa de um tempo dela, para ela observar como funciona, testar, e aí sim aceitar a interação... (Anotações pessoais, um ano e três meses de atendimento, Lola com três anos e quatro meses)

O modo como a cena é concluída pela terapeuta é coerente com a relação dela com a Lola o tempo todo: a terapeuta também a observa muito e, como ela não fala, tenta antecipar suas razões. Isto é fazer da relação terapêutica uma ocasião de diferenciação de momentos, movimentos, de lugares de enunciação. É lidar com a multiplicidade de acontecimentos e posições.

Cena 13

Hoje na escola um colega da turma da Lola levou um macaco de pelúcia. A Lola pegou emprestado perto da hora do lanche, e levou o macaco para o refeitório. Então, eu fiz algumas tentativas de pedir que ela desse um pouquinho da bolacha para o macaco, e depois do suco. Primeiro ela me olhou, como quem diz "é isso mesmo que você quer que eu faça?", eu sorri, e então ela levou uma bolacha para perto da boca do macaco e depois levou o macaco até o copo de suco. Então eu perguntei "E você, 
Lola, não vai querer o suco?", e ela respondeu dando um grito e colocando a mão no rosto. Eu falei, então, para ela "Então tá bom, é só falar 'não'. Vamos levar ele pro parque?" (porque os amigos já tinham terminado de comer), e na hora ela levantou da cadeira, pegou o macaco e foi. Chegando no parque, alguns colegas estavam brincando de subir na árvore, eu sugeri de fazermos o macaco subir também, e ela na hora o colocou em um galho e sorriu para ele. Pouco depois disso, outro colega quis brincar com o macaco, e Lola já estava com ele por muito tempo... Então, expliquei para ela que o macaco era de outro amigo, que tinha emprestado para ela brincar um pouco, mas que agora era a vez de outro amigo brincar também com o macaco. Ela entregou o macaco para o colega e caiu no choro. (Anotações pessoais, um ano e cinco meses de atendimento, Lola com três anos e seis meses)

A cena mostra a diferenciação entre o entendimento e o sentimento como parte da vida da Lola. Ela entendeu e fez o combinado, mas isso não quis dizer que ela não tivesse ficado triste...

\title{
Cena 14
}

\begin{abstract}
A retirada da chupeta da Lola está sendo muito difícil. Ela está sofrendo muito por ficar sem, e principalmente por não entender muito quando pode ter a chupeta e quando não pode. Então, conversando com a mãe dela, tive algumas ideias, e preparei uma história social em que quando vinha a noite, ficava escuro e aparecia a lua, depois de tomar banho, a mãe dela iria dar para ela a chupeta. Ela iria dormir com a chupeta e no dia seguinte, quando ela acordasse e já estivesse sol e claro, ela iria dar pra mãe ou pra babá a chupeta, e seguiria o dia sem. Até chegar a noite novamente e tudo recomeçar.

Deixei com a mãe em uma sessão, e ao final daquele dia, ela contou a história para a Lola que, segundo ela, viu as imagens e ouviu com muita atenção. No dia seguinte, a mãe leu para ela novamente a história, quando ela acordou, e pediu a chupeta para guardar. Lola resistiu um pouco, deu a chupeta para a mãe, depois chorou.

Isso tem se repetido em casa, e ela está mais tranquila por ter o tempo com a chupeta garantido e em horários determinados. Hoje na escola, quando ela viu um colega com a chupeta, tentou pegar, mas quando eu a lembrei que não era dela e que ainda estava de dia, ela logo se conformou, e saiu de perto do amigo... (Anotações pessoais, um ano e cinco meses de atendimento, Lola com três anos e seis meses)
\end{abstract}

A terapeuta, ao escrever que preparou uma história social para Lola, nos mostra como a considera em sua dificuldade para pensar em estratégias que podem esclarecer as regras e seu controle sobre elas. Mostra, também, como ela, terapeuta, se deixa guiar e criar pelas demandas da Lola e do ambiente... Tudo pela condição de cumplicidade e de reconhecimento dos sinais de Lola para que ela mesma possa lidar com os combinados.

O arbitrário pode ser contextualizado, os limites podem ganhar um sentido... Cena 15

Em janeiro, ainda nas férias, a Lola começou a ficar com várias bolinhas de calor nas costas, na região da fralda. Ela mesma ficou incomodada e começou a tirar a fralda, sozinha, em algumas ocasiões, por exemplo, em uma sessão comigo. Nós estávamos vendo um livro quando ela começou a coçar e tirou a fralda. Na hora nós pegamos uma calcinha da irmã dela, ela colocou e ficou tranquila. 
Nos dias que se seguiram, ela foi para o curso de férias da escola, e lá disseram para mim que ela não poderia tirar a fralda, teria que passar pelo ritual do desfralde da escola. Mas, por não ser ainda o período de aula, e não ter uma professora da turma ainda para acompanhá-la no processo, teríamos que aguardar feveiro.

Fiquei um pouco incomodada com essa postura da escola, uma vez que o tempo da Lola de retirar a fralda era aquele, e precisava ser levado em consideração também. Mesmo que para isso ela precisasse fazer a retirada da fralda em casa, e não fazer o ritual da escola.

Conversei com os pais de Lola, e eles acharam melhor aguardar a escola, que já havia demonstrado desconforto pelo irmão de Lola, no ano anterior, ter simplesmente decidido que não iria mais usar fraldas e ter ido sem para a escola, sem passar por ritual nenhum!

Fevereiro chegou, e com ele o carnaval e os alunos novos. E então a psicóloga e coordenação da escola, disseram que era melhor aguarda essa fase de adaptação, para então darmos início à retirada da fralda.

Março chegou, e não tinha mais desculpa. A professora da Lola me explicou como era o ritual: fazia-se uma roda com todas as crianças e ela iria anunciar que a criança em questão iria tirar a fralda, e que alguns escapes poderiam acontecer, mas que daquele momento em diante a criança usaria calcinha/cueca, e todos da turma iriam com ela ao banheiro retirar a fralda.

Conhecendo a Lola, preparei uma história social explicando o que iria acontecer naquele dia na escola, o que era um escape de xixi/cocô, e que a vida seguiria normalmente. Lemos na sessão, ela gostou da história, colocou a mão em sua própria fralda algumas vezes enquanto eu lia, e ela mesma quis levar o "livro" para a escola naquele dia.

Em determinado momento, a professora fez a roda, leu a história para Lola e os amigos da turma, e ao terminar de ler convidou todos a irem com ela ao banheiro. Colocou-a, então, em cima do trocador do banheiro, tirou a fralda (até aí, tudo bem rotineiro) e... colocou Lola no chão e deu a fralda para que ela jogasse no lixo, dizendo isso para ela.

Lola teve uma crise de choro terrível. Ficou vermelha, não soltou a fralda, queria bater na professora, tentava pegar outras fraldas que havia no banheiro, enfim... Eu segurei ela no colo, disse ter entendido que aquele não era o momento para ela, coloquei-a de volta no trocador, coloquei outra fralda, e retirei ela do trocador. Nesse momento, a professora já estava com as crianças fora do banheiro, e imagino que explicou algo para elas.

Mesmo de volta com a fralda, Lola demorou um bom tempo até conseguir se acalmar e parar de chorar. Quando já estava mais calma, ficou um tempo sem olhar e sem se aproximar da professora. Ela tinha ficado realmente sentida com o ocorrido.

Imagino, eu, que o fato de terem colocado ela no trocador tenha provocado nela a expectativa de ser trocada, e quando não foi, romperam uma rotina que para ela era muito estebelecida já. Além disso, solicitar que ela jogasse fora e desse tchau para a fralda fez de algo até certo ponto natural do desenvolvimento (retirada da fralda) como um evento, que foi por ela sentido de forma dramática.

Nos dias que se seguiram, as professoras continuaram levando ela ao banheiro com os colegas e oferecendo que ela fizesse xixi no vaso. Ela não só recusou todas as vezes como passou a detestar esse momento e até mesmo a aproximação do banheiro. (Anotações pessoais, um ano e seis meses de atendimento, Lola com três anos e sete meses)

\section{Podemos fazer alguns destaques:}

(a) Quando a terapeuta diz, ainda no início da cena, "Lemos na sessão, ela gostou da história, colocou a mão na própria fralda...": primeiro, que pela conjugação "lemos", podemos entender que as duas leem quando, na verdade, a terapeuta lê e Lola ouve, denotando certa sintonia que deve possibilitar outras formas de pertença e comunicação; 
segundo, que ao Lola colocar a mão em sua fralda e querer levar o livro para escola, mostrou ter entendido e adotado os meios disponíveis na relação com a terapeuta.

(b) Ao dizer, também, “Conhecendo a Lola...”, a terapeuta indica prever a dificuldade específica de Lola para a situação do desfralde, de que o ritual comumente apresentado a todas as crianças do grupo, conectadas às orientações coletivas, não poderia dispensar das orientações que seu próprio corpo e sensibilidade lhe dão.

(c) Quando a terapeuta diz “(...) segurei-a no colo, disse ter entendido que aquele não era o momento para ela", assinala para Lola seus limites como uma explicação para suas contrariedades e desconfortos. E, depois, levanta uma hipótese sobre o que foi o limite "Imagino, eu, que o fato de a terem colocado no trocador tenha provocado nela a expectativa de ser trocada...".

(d) Nesta cena, a terapeuta teve que se haver com os procedimentos da escola e a quebra de expectativas de Lola. E a história social não teve o alcance e a adesividade necessária para fazer resistir à lembrança ou a imaginação até o fim do jogo...

\section{Cena 16}

(...) Antes de a Lola ir para a fono, a Maria estava preparando um potinho com um pedaço de bolo e deu um pedacinho para ela. Ela comeu, em pé, pela cozinha, e a Maria continuou arrumando a lancheirinha dela. Então, ela foi em direção ao balcão da cozinha, estendeu os braços na tentativa de pegar mais, e soltou "mais!". Nós ficamos tão felizes, mas tão felizes... Ela falou espontaneamente, pela primeira vez!!! (Anotações pessoais, um ano e nove meses de atendimento, Lola com três anos e dez meses)

A primeira palavra de Lola com o sentido de comunicação foi "mais"; a demanda dela pode se traduzir numa palavra e obter satisfação imediata.

\section{Cena 17}

Na semana passada eu fui chamada pela coordernadora da escola para conversar sobre a Lola. Ela fez algumas observações sobre o desenvolvimento da Lola na escola, seus progressos, e também me perguntou sobre a importância de Lola trazer de casa e carregar consigo o tempo todo alguns objetos nas mãos. Ela disse que a professora estava preocupada pois Lola levava brinquedos ou objetos todos os dias para escola, não cumprindo o combinado de poder levar apenas na segunda-feira.

Eu expliquei para a coordenadora que entendia a preocupação da professora, entretanto, havia um processo nesse "carregar objetos" que precisava ser considerado: Lola, desde que tinha entrado na escola, carregava consigo objetos aleatórios, como sachê de ketchup, bola, bexiga, papel de propaganda, que de um jeito ou de outro eram sempre retirados dela por sua inadequação (por ser alimento, por não ser permitido levar na escola, por não ter uma função compartilhada). Mas, a partir de maio daquele ano, passara a levar sempre um ursinho azul, que era de seu irmão mais velho, e que, como um urso, era permitido na escola.

Ela não brincava com o ursinho, não usava o ursinho como um brinquedo, atribuindo funções, ou mesmo imaginando situações com ele; ela apenas o carregava, como algo que lhe era muito familiar e lhe trazia um conforto emocional. O ursinho, embora para 
outras crianças pudesse ser utilizado como um brinquedo, para ela não era, e precisávamos considerar a especificidade do objeto no percurso de Lola na escola, e também em sua individualidade. Me dispus a conversar com a professora e até mesmo com a turma, explicando o que era o urso azul para Lola. A coordenadora disse ter compreendido, e pediu, então, que eu conversasse com a professora e com a turma.

Primeiro eu expliquei para a professora, que viu um sentido na minha explicação, e depois, juntas, conversamos com a turma, explicando e pedindo a compreensão dos colegas sobre esse momento que Lola precisava ter com algo que lhe desse segurança. As crianças entenderam e imediatamente acolheram Lola. Daquele dia em diante, ninguém mais tentou tirar de Lola o urso, nem pediu emprestado como era feito com os brinquedos. E nessa segunda, dia do brinquedo, Lola levou o urso (como nos outros dias) e um brinquedo para usar com os amigos e emprestar. (Anotações pessoais, um ano e nove meses de atendimento, Lola com três anos e dez meses)

Inicialmente, temos os limites da escola a Lola que parece, mais que seus colegas, estender a casa para outros ambientes. Quando ela começa a levar o urso azul, o objeto adequado ao contexto de sala de aula, parece cumprir a mesma função dos outros: portar algo familiar.

Lola, entretanto, ainda precisa de uma ponte. E é a terapeuta quem faz a ponte dos sentidos atribuídos por ela e aqueles exigidos no contexto social. A terapeuta explica: agora não para a Lola, mas para seus interlocutores, para que ela pudesse se dar condições de conforto. A mágica dessa explicação? O acolhimento de Lola e de seus recursos de segurança afetiva pelos colegas (“As crianças entenderam e imediatamente acolheram Lola”).

No momento seguinte, Lola é incentivada a compartilhar também, mesmo que fosse algo não tão importante assim para ela...

\section{Cena 18}

Embora a Lola já esteja falando algumas palavrinhas, ainda é difícil para ela responder a algo que perguntamos. Quando ela não quer, ela costuma gritar, e quando ela quer ela fica em silêncio. Então, pensando nisso, resolvi tentar ensiná-la a dizer "sim" e "não".

Nessas últimas 6 semanas levei alguns jogos para a sessão em que poderia fazer com que essas palavras ficassem frequentes. Um deles, por exemplo, tínhamos que achar nas cartelas um mesmo objeto, e ao juntar as cartelas, formava o nome do objeto. Juntei o interesse dela por letras, palavras e alfabetização, com algo novo. Ao procurarmos os objetos pelas cartelas eu ia perguntando e respondendo, inicialmente "Tem bolo (objeto) nessa? Não..." ou então "Tem bolo nessa? Sim!!!". Fizemos algumas vezes essa brincadeira apenas comigo respondendo. Depois, vi que ela começou a responder junto comigo, "mão", para não, e "xiiiim", para sim. Por fim, eu só perguntava e ela mesma respondia.

Usamos também outros jogos, e um dia em casa a mãe não estava entendendo o desenho animado que ela queria e perguntou "Você quer o Mickey, Lola?" e ela respondeu "Xiiiim". (Anotações pessoais, um ano e onze meses de atendimento, Lola com quatro anos) 
Temos aqui, novamente, o acompanhamento do andar e das conquistas desta pequena, por parte de sua terapeuta, para ampliar seus recursos de comunicação: a adequação e a generalização do uso de um termo, de acordo com sua demanda.

\section{Cena 19}

Hoje aconteceu uma brincadeira muito divertida no parque, entre mim e a Lola. Ela viu alguns amigos correndo, brincando de pega-pega, e começou a correr atrás deles. Eu fiquei parada, um pouco distante, observando. Logo vi que ela se dispersou do grupo e continuou correndo sozinha. Ela correu para um espaço em que eu não conseguia vê-la de onde eu estava, então, andei um pouco até conseguir alcançá-la com os olhos. Vi que ela deitou no chão, mas que estava com uma carinha sorridente, não era porque tinha caído ou porque não estava bem. Continuei acompanhando à distância, quando percebo que ela está olhando pra mim. Dou um sorriso para ela, ela sorri para mim de volta, e mantém o contato visual. Espero para ver o que vai acontecer, e então ela, deitada no chão e sorrindo, começa a me chamar usando o dedo indicador, fazendo o movimento de apontar. No clima de brincadeira, corri até ela e lhe fiz cócegas, dizendo que estava feliz de ela me chamar para brincar com ela. Ela, então, sorria mais ainda e dava risadas. Levantou, então, disse "aqui!" e saiu correndo, como quem diz, "vem me pegar!". Eu aceitei prontamente o convite, e corri atrás dela. E, aí, ela parava, eu pegava ela dizendo "Peguei! Peguei você!", e ela deitava no chão para que eu fizesse cócegas.

Foi muito incrível ver a Lola, a partir de uma percepção da brincadeira dos colegas, criar uma brincadeira comigo, e sustentar essa interação com gesto, olhar, expressão facial e palavra. (Anotações pessoais, dois anos e um mês de atendimento, Lola com quatro anos e dois meses)

As observações da terapeuta respeitam os acasos e promovem novos acontecimentos na relação. Até que ela mesma, capitaneie o movimento do brincar e lhe dê sentido pleno.

Cena 20

Lola já está percebendo e entendendo muito das coisas que acontecem ao seu redor. Está mais conectada às pessoas que ama, e de quem sente falta. A mãe dela me contou que nos últimos dias, ao ouvir o barulho do portão da garagem, ela tem chorado muito e ficado desesperada. Ela não sabe quando a mãe está saindo para trabalhar e voltará ao final do dia, e quando a mãe está saindo para viajar à trabalho e demorará alguns dias para voltar.

Sugeri para a mãe que fizéssemos uma história social contando para Lola tudo que a mãe faz e para onde ela vai quando não está em casa, como: pela manhã ela sai para ir ao supermercado, à tarde ela sai para o trabalho e à noite ela volta para casa. E uma outra contando quando a mãe vai viajar, os dias que demorará pra voltar, para ela ir acompanhando.

Usamos as duas histórias, em momentos diferentes, e Lola conseguiu entender. Carregava o livro pra cima e pra baixo, e ao ouvir o portão da garagem, quando eu estava com ela, tentava sempre lembrá-la sobre onde a mãe estava indo, e de que ela iria voltar.

Aos poucos Lola foi entendendo, deixando as histórias, e tendo segurança de que sim, a mãe iria voltar, como sempre volta! (Anotações pessoais, dois anos e um mês de atendimento, Lola com quatro anos e dois meses) 
Temos aqui outro aproveitamento de situações cotidianas com a história social para situar Lola no contexto e dar-lhe segurança afetiva. A sessão terapêutica é como um elo para o entendimento dessas situações.

Cena 21

(...) Tinha sido um dia bem cansativo na escola. Lola estava saindo do parque, após correr e brincar bastante, quando veio até mim e estendeu os braços. Perguntei o que ela queria, mesmo sabendo pelo seu movimento, mas com a intenção de solicitar sua fala. Ela não respondeu. A professora chamou para o jantar, precisávamos ir. Eu disse para ela que tínhamos que ir para o refeitório. Ela novamente estendeu os braços e eu perguntei o que ela queria que eu fizesse. Ela não respondeu novamente. Então, dei um passo, ela sentou agarrada no pé, e antes que eu pudesse dizer qualquer coisa, ela olhou para cima, na direção do meu rosto, e disse com certa dificuldade em pronunciar as palavras: "me segura". Eu a segurei e, por dentro, desmontei.

Talvez a demora dela em me responder fosse por não saber como pedir colo, ou então, fosse por estar buscando na sua cabecinha a palavra que queria me dizer, ou mesmo tentando articular a expressão verbalmente. Quanto esforço, minha pequena! (Anotações pessoais, dois anos e dois meses de atendimento, Lola com quatro anos e três meses)

A comunicação, a serviço de seu bem-estar e bem colocada, é acompanhada pari passu pela terapeuta numa sintonia única com o esforço da pequena. Quem desmonta ao final é ela, a terapeuta. Mas, nisso e com isso, segura-a...

Cena 22

Com a chegada do verão e volta das bolinhas de calor na Lola por conta da fralda, esperei que ela entrasse em férias da escola para fazer uma nova tentativa de retirada da fralda. A mãe e a babá também já tinham comentado comigo que antes de entrar no banho ela estava sentando no vaso para fazer xixi, então alguma abertura para essa passagem estava acontecendo...

Havia feito, também, algumas brincadeiras com água na casa dela, em que ela e os irmãos ficaram com roupas de banho, e ela aceitou ficar sem a fralda. E nos finais de semana de sol os pais relataram que ela também aceitou o biquine no lugar da fralda para irem para a piscina.

Então, na penúltima sessão do ano, eu levei como uma lembrança de natal, uma calcinha para ela e outra para irmã. Bem coloridas, com desenhos, para ver se ela ficava motivada. Dei assim que cheguei em sua casa. Ela e a irmã abriram juntas e ficaram muito animadas com o presente. A irmã quis logo trocar de calcinha, e Lola aproveitou o embalo, tirou a fralda e colocou também!

Fizemos uma atividade com tinta, e em seguida ela foi tomar banho. Combinei com sua babá que tentaríamos colocar a calcinha novamente, após o banho, sem colocá-la no trocador do banheiro, sem falar nada, como algo muito natural e que acontece sempre com meninas de sua idade! E... deu certo!

Lola aceitou a calcinha logo que saiu do banho! Fez xixi no vaso em outros momentos do dia quando foi levada ao banheiro, e eu mostrei para ela uma nova história dizendo sobre como era bom usar calcinha, e que às vezes ela teria que perceber que queria fazer xixi e correr para o banheiro! Ela achou divertido, e aceitou a proposta.

Claro que tivemos alguns escapes, mas Lola seguiu firme com a calcinha, sem nem precisar dar tchau e jogar a fralda no lixo com uma grande plateia! (Anotações pessoais, dois anos e três meses de atendimento, Lola com quatro anos e quatro meses) 
A atenção a cada passagem de uma conquista a outra por parte da terapeuta ajuda Lola a tornar a situação toda em um jogo divertido consentido. Em verdade, o que poderiam ser chamadas de "boas ideias" da terapeuta, são transformadas em "ótimas respostas e ações" de Lola.

Cena 23

\begin{abstract}
Hoje na escola, assim que cheguei, vi que a professora tinha deixado alguns panos para as crianças brincarem livres, e notei que Lola estava andando de um lado para o outro, meio olhando as crianças, vez ou outra passando a mão em algum tecido... Então, olhei a caixa e vi que tinha um pano vermelho. Peguei e perguntei se ela queria ser a chapeuzinho vermelho. Ela respondeu "xim!", e então eu fiz para ela um capuz com uma capa vermelhos, peguei um outro pano florido e falei que poderia ser a cesta, e que ela estava pronta para passear no bosque e levar os doces para a vovó. Ela sorriu e saiu pela sala caminhando, balançando a cesta. Em seguida, outras meninas da turma vieram me pedir para fazer capuz e capa para elas também. E em pouco tempo, tínhamos ali uma legião de chapeuzinhos... (Anotações pessoais, dois anos e cinco meses de atendimento, Lola com quatro anos e seis meses)
\end{abstract}

Nesta cena, uma vez que Lola parecia não conseguir ela mesma criar uma brincadeira com os tecidos, ou participar de uma brincadeira com os colegas, "emprestei a ela minha imaginação", dentro de um contexto que lhe era familiar: a história da chapeuzinho vermelho. E a partir do aceite dela de entrar na nossa brincadeira imaginativa (agora não mais só minha) outras crianças quiseram brincar também. E Lola não estava mais sozinha.

Cena 24

(...) Jogamos depois o jogo Spot it, em que cada um recebe uma carta com várias
imagens, colocamos uma das cartas no meio, e quem achar primeiro a imagem que há
igual na sua carta com a carta do meio, coloca sua carta em cima. Enquanto nós
jogávamos, eu percebi que apenas eu falava "Eu tenho o golfinho!” e colocava minha
carta no meio. Ela apenas apontava o animal que ela tinha igual e colocava a carta.
Pedi que ela fizesse como eu, e usasse suas palavras para dizer a imagem igual que
tinha encontrado. Percebi que ela precisava sempre que eu dissesse como ela deveria
dizer para aí ela repetir. Pensei, então, que seria importante ela ter certa autonomia em
dizer, mesmo que a frase fosse uma já estabelecida. Então, peguei o caderno e escrevi
numa folha "eu tenho..." e assim que ela apontava para a carta, eu a chamava e
apontava para o caderno. Ela lia, e completava com o nome da imagem. Isso aconteceu
umas cinco vezes, e depois ela disse espontaneamente "Eu tenho o flamingo!”, e assim
seguimos o jogo, sem que ela nem precisasse ler no caderno! (Anotações pessoais,
dois anos e oito meses de atendimento, Lola com quatro anos e nove meses)

Nesta cena algumas coisas nos chamam a atenção: (1) Lola sabe falar, tem vocabulário, também sabe brincar com o jogo, mas ainda assim tem dificuldade de estruturar uma frase; (2) eu estou presente na brincadeira com ela, atenta ao modo como ela brinca, eu percebo que ela participa do jogo sem usar as palavas e solicito que as use; (3) Lola entende a solicitação, tenta, mas faz de forma dependente da minha voz para lembrá-la; (4) eu percebo que ela precisa 
conseguir ter certa autonomia, e escrevo, pois sei que ela sabe ler, e também porque acredito que a imagem possa ajudá-la a memorizar melhor. Vejam, o tempo todo eu estou atenta a ela, ao modo que ela faz, e como poderia ser diferente, considerando suas dificuldades, mas pensando em como superá-las. Eu dou suporte, passo confiança, e ela segue.

Minha escuta não é só com os ouvidos, com o que é dito e eu ouço; minha escuta é com o que eu vejo e percebo dela, o tempo todo. É o que eu imagino que ela possa fazer, é o que eu imagino que ela precisa fazer, é o lugar que eu atribuo a ela nessa nossa relação: um lugar de potência. A fala dela não é só com os sons de palavras que exprime com a boca; ela se comunica com gestos, movimentos, e reagindo ao meu comportamento também. Ela faz o que ela sabe, aceita os desafios que proponho, ocupa o lugar que eu atribuo a ela, e me atribui um também: um lugar de confiança.

Os lugares, os papéis, as atribuições e expectativas estão presentes o tempo todo, dentro e fora do jogo.

\section{Cena 25}

(...) Eu vi que a Lola estava olhando bastante para o Batman do Artur, ela tentou pegar algumas vezes, ficando próxima, mas não conseguiu pegar. Eu perguntei se ela queria ver, se queria emprestado. Ela disse que sim. Falei para ela pedir pra ele, dizendo "me empresta o Batman?". Ela falou, mas ele estava de costas. Avisei que ele precisaria estar olhando para ela, e que ela precisava falar mais alto para que ele pudesse ouvila. Chamei, então, o Artur pelo nome, e disse que a Lola queria falar com ele. Na hora ele olhou para ela, e ela pediu o Batman emprestado. Ele deu, e foi brincar com outro amigo.

Lola ficou muito interessada no Batman. Mexeu na capa, eu falei para ela que o Batman voava e ela fez com o boneco o movimento de voo, colocou no chão, jogou para cima, explorou as múltiplas possibilidades do herói. Nisso, eu olhei para o lado e vi o Joaquim brincando com uma nave do Star Wars, sozinho. Por alguma razão ele estava fazendo a nave bater numa parede. Naquele momento, pensei que eles poderiam brincar juntos, e que eu poderia ajudá-los a fazer uma história. Então, falei para Lola: "Lo, olha só! A nave do Quim vai bater neste planeta! Acho melhor o Batman ir ajudar, desviando a nave do caminho!'. Lola riu. Quim riu. Incentivei Lola a fazer o Batman, de fato, ajudar a nave a desviar. Ela fez. Eu narrei. Os dois deram risada e repetiram depois a brincadeira algumas vezes, com o Quim narrando. (Anotações pessoais, dois anos e oito meses de atendimento, Lola com quatro anos e nove meses)

Nessa cena primeiro eu verifico com Lola minha impressão (de que ela queria o Batman do amigo), depois, digo para ela como ela pode fazer para tentar tê-lo. Noto sua dificuldade, ajudo parcialmente (chamando o amigo e dizendo que Lola queria falar com ela), saio de cena. Lola segue com os recursos que tem (a vontade de brincar, o modelo da frase) e alcança seu objetivo. 
Então, eu tento dar um passo além, buscando para ela uma outra ocasião de interação, com um elemento novo: a imaginação. Nesse momento, sou eu quem procuro um parceiro da idade dela para que ela interaja e imagino uma cena. Proponho a cena imaginada aos dois. Eles parecem gostar da ideia. Incentivo Lola a executar a ideia, e continuo dando suporte narrando. Novamente os dois parecem gostar do ocorrido. Eles repetem a cena, mas aí eu fico de fora; Lola já consegue participar executando ações com sua personagem, Quim com a dele, e Quim narra.

O suporte que dou é o tempo todo parcial, apenas o suficiente para passar confiança e tornar possível a interação de Lola com os colegas. O vínculo que estabeleci com o Lola durante todo o processo terapêutico possibilita até isso: que meu lugar e minha participação fiquem em suspenso em alguns momentos, para que outras pessoas possam ser interlocutores dela também!

Cena 26

(...) Aí, de sobremesa após o jantar, Lola recebeu uma banana descascada. Sem nem titubear, colocou no ouvido e falou "alô?". Quem diria que agora ela mesma estaria iniciando brincadeiras imaginativas! (Anotações pessoais, dois anos e nove meses de atendimento, Lola com quatro anos e dez meses)

Não importa que a cena inventada por Lola não tenha se estendido para além do "alô". Foi um começo e, como tal, precisa ser reconhecido e comemorado!

Cena 27

(...) A irmã da Helena foi na escola hoje, contar sobre como é ir para o primeiro ano
em outra escola. Ao final da roda, a professora passou de criança por criança
perguntando se elas queriam perguntar algo sobre a escola delas à irmã da Helena,
que por ser mais velha e ter estudado lá, poderia responder para eles. Nem todas as
crianças quiseram fazer perguntas. Quando chegou na vez da Lola, mais do que de
pressa ela aceitou a proposta! A professora pediu que ela se levantasse e fizesse a
pergunta de pé, para todos ouvirem. Ela se levantou, e começou a falar. Falou tão
baixinho, que ninguém entendeu sua pergunta. Eu me aproximei, pedi para ela falar
mais alto, mas mesmo assim não foi suficiente. Então, aguardei ela terminar de falar,
entendi que tinha algo na pergunta relacionada a casinha de madeira, e falei "Lola, a
gente quis muito te ouvir, mas não conseguimos. Eu escutei você perguntar algo sobre
a casinha de madeira. O que você queria perguntar para ela sobre a casinha?" e ela me
respondeu "conhece?". Eu retomei perguntando se ela queria saber se a ex-aluna
conhecia a casinha de madeira, e ela disse que sim. Então, pedi para ela perguntar
isso, e ir falar bem pertinho da menina. Ela assim o fez, e a irmã da Helena respondeu
que sim, que conhecia. (Anotações pessoais, três anos e um mês de atendimento, Lola
com cinco anos e dois meses)

De toda essa cena, poderíamos comentar aqui sobre o volume de sua fala, sobre a pergunta que ela fez e ninguém ouviu, sobre como ela pode ter se sentido incompreendida... Mas preciso dizer a você, leitor, que Lola parecia bem feliz na ocasião. E por ela parecer 
confortável naquele momento, eu só posso considerar aqui que o mais importante dessa cena foi sua vontade de fazer uma pergunta; sua coragem de se levantar e falar, mesmo que pudesse não ser ouvida; sua confiança de que seu espaço e lugar de fala e interlocução estava garantido pela sua professora, por mim, pelos seus colegas. Lola quis dizer, e nós queríamos ouvi-la!

Lola, pode-se dizer, é um ícone da possibilidade de a relação terapêutica ser ocasião do desenvolvimento da comunicação de uma pequena com o mundo.

A terapeuta segue Lola em suas competências e dificuldades para se haver com a realidade de sua vida desde os dois anos de idade. Lola, sem o recurso da fala, de início, entregase ao vínculo que a move para além de seu diagnóstico de autismo.

Uma confiança mútua é o que mais se mostra nas cenas apresentadas como carro-chefe desse movimento.

A contundência da narrativa nas cenas nos leva a destacar:

a) A instauração de uma rede de sentidos, a partir das "traduções" que a terapeuta arrisca fazer a partir de expressões/ações de Lola, sem medo de errar.

b) Os efeitos na reorientação dessas manifestações da "pequena" (como é nomeada no texto) são visíveis, ora indicando um "Sim! É isto mesmo!", ora mostrando uma contrariada aceitação em que ela cedia ao caminho oferecido pela terapeuta, ao mesmo tempo em que sugeria que isto lhe custou frustração e esforço.

c) Cada uma dessas sequências tinha a verbalização da terapeuta, muitas vezes afirmando expressamente, que ela entendia tal ou qual coisa/reação/acontecimento;

d) Outra característica importante deste acompanhamento: a imediatez com que a terapeuta age à mínima reação de Lola. Haja vista, na cena do treino de toalete na escola, em que ela a toma imediatamente ao colo dizendo-lhe: "Isto ainda não dá pra fazer". Coloca-lhe a fralda limpa e entra com ela na sala de aula.

e) Isto seria mais fácil em momentos de alegria, como no caso de Lola pedir "mais", como primeira manifestação verbal espontânea (foi festa geral na cozinha), mas a menina é sempre acompanhada atentamente, nessas ocasiões e naquelas mais tristes.

f) É interessante que o alvo geralmente apresentado é a ampliação de possibilidades de comunicação de Lola. E de fato, o desenrolar dos acontecimentos mostra que ela consegue fazer isto; mesmo que se lhe imponha que expresse de diversas formas, que quer dizer algo, que quer conseguir algo, como foi o caso do "me segura": contundente relato que aponta o desempenho dessas duas parceiras na produção de uma comunicação verbal em tudo ajustada à demanda de uma e ao atendimento de outra. 
g) Aliás, nesse sentido, é que se acompanha uma descoberta que chama a atenção: Lola aprende a falar aprendendo a ler! Siga-se a Cena 5 para que se esclareça todo o movimento da atenção da terapeuta que oportunamente passa do som produzido pelos animais à apresentação das letras (vogais) que também são produtoras de som. É uma virada mágica que aproveita as (e confia nas) condições de interesse e competência para entender essas associações e deslizamento de som a coisas, animais, letras. E, com isso, Lola se mostra aplicada aos aprendizados dos primeiros passos de sua alfabetização.

h) Fica claro nessa ocasião que não há um privilégio dos métodos já reconhecidos como os mais adequados à idade e ao desenvolvimento da criança. O que há é o privilégio das condições e predisposições de Lola no contexto terapêutico.

i) $\mathrm{O}$ acaso e acontecimento caracterizando o discurso é que responde pelos surpreendentes rumos na vida de aprendiz dessa pequena menina em terapia.

j) A presteza de apresentação de recursos, casualmente tem efeitos interessantes na avaliação da memória afetiva, da compreensão de mecanismos da Lola, bem como a eficácia dos procedimentos propostos. É o caso das histórias sociais ${ }^{43}$ em que a terapeuta aposta facilitar a capacidade de antecipação do que irá acontecer e, com isso, a redução dos sofrimentos e das dificuldades previstas para certas exigências cotidianas (ausência da mãe, treino de toalete).

k) Veja-se que é "Lola inteira" que está em foco pelas ações da terapeuta, não apenas situações de jogos e brincadeiras. Em algumas interações há uma multiplicidade de invenções sobre o que é que está em jogo, o que a pequena demanda, o que pode oferecer, o que pode aprender e assim por diante.

1) Lola responde inteira e intensamente também.

m) Notem-se as diversas situações em que a terapeuta escreve o que é feito na primeira pessoa do plural. Sente-se acompanhada e acompanha. E as coisas acontecem...

n) Acaso e acontecimento na produção de sentidos como um moto-contínuo nessa relação de parceria tão firme. Ora, isso é uma análise no ato mesmo em que a relação se faz. Nesse caso, em grande parte, brincando... Brincando de diversos modos e em torno de diversos domínios...

${ }^{43}$ Social Stories ${ }^{\circledR}$ 


\subsubsection{Otávio: atenção e curiosidade no ingresso ao mundo da imaginação e da brincadeira}

Todo o atendimento de Otávio foi realizado com a AID. Na ocasião, nós já tínhamos a certificação da escala ADOS, e esta foi aplicada no início e uma vez durante o trabalho com ele, que ainda não foi finalizado.

\subsubsection{Breve histórico}

Otávio é filho único, de pais jovens, sendo a mãe psicóloga e o pai formado em tecnologia da informação.

A mãe relatou que já no aleitamento natural (durou sete meses), notava que o filho não fazia contato visual. Com um ano de idade, Otávio passou a ir para a escola no período integral. Ao final do primeiro ano, a professora de sua turma relatou que ele parecia desatento, gostava de andar pela sala, não obedecia comandos e gostava de ficar mais sozinho.

Os pais ficaram preocupados, levaram Otávio a um neuropediatra que solicitou alguns exames laboratoriais, e no início do ano seguinte, logo após completar dois anos, levaram-no a uma fonoaudióloga conhecida da família. Na ocasião, a queixa principal da família era a de que o filho não falava e não se comunicava.

Após avaliação, a fonoaudióloga indicou que Otávio iniciasse terapia fonoaudiológica, psicoterapia, orientação escolar e familiar, e avaliação audiológica (devido ao histórico de otite de repetição). A partir de uma escala preenchida pelos pais sobre sinais de autismo, durante a consulta com a fonoaudióloga, foi levantada a hipótese diagnóstica de TEA.

Aos dois anos e dois meses Otávio iniciou um trabalho de psicoterapia com uma equipe de terapia comportamental, três vezes na semana, na casa, com duração de 1 hora, com a qual seguiu até os três anos e onze meses. Também aos dois anos e dois meses ele começou a terapia fonoaudiológica.

Aos dois anos e meio, iniciou a terapia ocupacional, uma vez na semana, por conta das questões sensoriais e motoras que apresentava. Seguiu até os quatro anos e meio, quando foi sugerido à família que buscasse um atendimento com psicomotricista para auxiliar Otávio na motricidade geral. 
Quando estava com três anos ele mudou de escola, conforme a vontade dos pais e dos terapeutas (pois alegavam que a escola tinha dificuldade em seguir as orientações dadas), para uma que solicitou desde o início alguém que o acompanhasse em sala três vezes na semana, e depois ampliou para cinco vezes. Essa pessoa que acompanhou Otávio era da equipe da terapia comportamental, e o auxiliou naquele ano.

É importante dizer que Otávio apresentava restrição alimentar significativa nesta época, muita constipação, e com frequência adoecia por conta de otite e problemas respiratórios. Com três anos ele teve que fazer um procedimento para introduzir tubos de ventilação nos ouvidos para auxiliar no tratamento das otites e com quatro anos deu início a um tratamento para asma.

Aos três anos e dez meses de idade, a mãe de Otávio entrou em contato comigo, por indicação da escola. Na ocasião, também, a equipe comportamental havia tido alguns conflitos na escola, devido à abordagem de trabalho. Consideravam ser importante para Otávio alguém que interagisse com ele de outra maneira.

Conforme o relato da mãe no primeiro contato, ela gostaria de conhecer minha abordagem (a AID), e conversar comigo sobre o filho e os desafios que estava enfrentando com ele naquele momento: falta de recursos para comunicação; bastante agitado; não vendo sentido nas tarefas que lhe eram solicitadas, respondendo apenas para obter algo que quisesse.

Otávio foi avaliado pela ADOS aos três anos e onze meses, e segue em atendimento até o presente momento, com cinco anos e três meses. Ele é atendido em sua residência, por mim, duas vezes na semana, por uma hora, e eu oriento a acompanhante terapêtica dele na escola, bem como preparo o material pedagógico.

Pouco antes de completar quatro anos e meio, a pedido de sua família e em consonância com as observações dos demais profissionais que o atendiam, fizemos a indicação de Otávio para uma neurologista infantil, para que pudesse avaliar as questões relacionadas à agitação motora. Na consulta, o diagnóstico de autismo foi fechado, e a ele foi associado o quadro de deficiência intelectual. Sobre a agitação motora, foi sugerido que aguardássemos mais alguns meses para que fosse feita uma nova avaliação e, possivelmente, a entrada de um medicamento alopático.

Quando estava com quatro anos e meio deu início a um acompanhamento com nutricionista para introdução de novos alimentos que seguiu com sucesso até os cinco anos de idade, momento em que não foi mais necessário. As constipações e flatulências permaneceram, apesar de todas as investigações médicas (relacionadas a alergias alimentares, principalmente). 
Nesta mesma época, ele começou uma terapia fonoaudiológica voltada para apraxia, duas vezes na semana. Aos cinco anos, ele iniciou a terapia domiciliar com o psicomotricista uma vez na semana, manteve a fonoterapia voltada para apraxia uma vez na semana e uma fonoterapia para comunicação alternativa também uma vez na semana. Iniciou, também, tratamento com homeopatia para auxiliar nas questões da agitação motora, bem como às relacionadas à constipação.

Assim segue Otávio, com uma equipe multidisciplinar muito atenta a ele e às suas necessidades, e com pais presentes, participativos e, acima de tudo, muito amorosos.

\subsubsection{Sobre o desenvolvimento de Otávio durante o atendimento}

Otávio é um menino loiro, alto, forte, de sorriso fácil e cativante. É carinhoso e está sempre pronto para nos guiar pela mão com o objetivo obter o que quer: em geral, guloseimas, mas também para abrir a porta e sair de lugares fechados!

O primeiro dia em que nos vimos e interagimos, por uma hora consecutiva, foi na ocasião da avaliação ADOS. Otávio chegou sorridente, andando, com seu fiel escudeiro de pelúcia (um pônei azul), e logo dirigiu-se para a sala de atendimento, com muita independência.

Naquela ocasião, Otávio fez diversas vocalizações e as direcionou de forma espontânea para a mãe e para mim em contextos diversos, e fez uso de uma palavra reconhecível, "mama"/"mamã". Devido a limitação da linguagem na ocasião, não foi possível avaliar a entonação de suas vocalizações e/ou verbalizações, presença de ecolalia imediata, uso estereotipado e/ou idiossincrático de palavras.

Para comunicar que gostaria de sair da sala, ele fez uso de minha mão como ferramenta para tentar abrir a porta, sem tentar previamente direcionar minha atenção estabelecendo contato visual.

Otávio não fez uso do apontar com o propósito de solicitar algo ou de atenção compartilhada e, também, não fez uso espontâneo de gestos descritivos, convencionais, instrumentais ou emocionais.

Otávio respondeu quando chamado pelo nome na quarta tentativa, respondeu na primeira tentativa ao sorriso social e dirigiu algumas expressões faciais com o objetivo de comunicar afeto para mim e para a mãe. Fez uso do contato visual para indicar abertura social, mas de forma não integrada com a vocalização e/ou os gestos. Demonstrou prazer apenas na atividade com a bexiga, e com um material que não fazia parte da avaliação. 
Ao solicitar ajuda para algo de seu interesse, fez contato visual e direcionou o objeto para a terapeuta. Deu espontaneamente um objeto, como parte de uma rotina, mas não chegou a mostrar, também de modo espontâneo, algo de seu interesse.

Ele não iniciou, por si, momentos de atenção compartilhada com o objetivo de dirigir a atenção de outra pessoa para um objeto que estava fora de seu alcance, mas seguiu o apontar da examinadora olhando em direção ao que ela estava mostrando para ele.

De modo geral, as aberturas sociais de Otávio foram restritas aos seus interesses e demandas pessoais, mas de forma inconsistente. Apresentou dificuldade em sustentar para o outro essa abertura insistindo no contato visual e integrando-o a outras formas de comunicação (vocalização ou gesto).

Em relação aos brinquedos disponíveis, brincou espontânea e funcionalmente com os brinquedos de causa-efeito (pop-up, caixa de música), não demonstrou interesse pelas miniaturas, e não conseguiu imitar e/ou reproduzir brincadeiras com outros objetos representacionais.

Ao ser solicitado por sua mãe a imitar bater palma, em troca de ter acesso a parte do tapete que demonstrou interesse, Otávio o fez. Conforme relato da mãe, ele estava habituado a fazer esta imitação em específico em terapia para alcançar sua recompensa. Quando solicitei que a mãe pedisse uma imitação com objeto (isto é, diferente da que ele estava acostumado a fazer), ele não conseguiu fazê-la, indicando que a imitação da palma estava associada a uma resposta específica aprendida por repetição, e não pela generalização do ato de imitar.

Otávio apresentou comportamentos de busca sensorial com materiais da avaliação (bolinha e golfinho) colocando-os na boca, e também com materiais fora da avaliação, como o copo de plástico para apertar e uma tira do tapete de e.v.a. para observar o movimento.

Ele se movimentou constantemente pela sala, apresentando dificuldade em permanecer sentado para a realização de algumas atividades.

Não foi observado maneirismo e nem comportamentos repetitivos com as mãos e dedos. Ele não apresentou comportamentos de autoagressão, nem comportamentos disruptivos e/ou agressivos.

Conforme os critérios desta avalição, Otávio apresentou características associadadas ao TEA suficientes para preencher o critério clínico deste diagnóstico no nível moderado.

As primeiras sessões com Otávio foram ocasião de aprendizagem para mim, no sentido de observar e tentar entender o que como ele brincava, como ele ocupava o espaço da sala que 
tínhamos disponível em sua casa, por quais objetos ele se interessava. Levei alguns, com base na avaliação, mas também solicitei que sua mãe deixasse outros dele mesmo disponíveis.

Nessas sessões, algumas coisas chamaram minha atenção: Otávio gostava de se movimentar (andar, ou pular na cama elástica), embora seu caminhar não tivesse um alvo, um objetivo. Ele caminhava de um lado para o outro, por vezes no meio do caminho sentava no chão ou na cadeira, mas não parecia estar procurando algo, nem tão pouco se dirigia a algum objeto em específico para pegar ou explorar. Inicialmente deixei todos os brinquedos em um canto da sala, para ver se ele iria buscar por eles, usando-os como algo para dirigir sua atenção; mas não tive o resultado esperado... Ele continuava caminhando, e ora pisava nos brinquedos, ora pegava um ou outro e jogava para outro canto da sala. Decidi, então, mudar de estratégia e montei alguns espaços com brinquedos parecidos. Pareceu dar mais certo: conforme ele andava, tinha mais objetos chamando sua atenção, e ele passou a pegar mais os brinquedos, embora ainda fosse um pegar aqui, para logo jogar ali. Isso de pegar e jogar era bem comum e frequente, sendo que também acontecia com sua garrafinha de água e com alimentos.

Conversando com sua mãe, ela contou que ele estava em uma fase difícil de querer ficar e permanecer sentado, e ela atribuía ao fato de com a outra terapia isso lhe ser exigido constantemente e de ele não ver um sentido nessa solicitação, ficando irritado.

Comentei com ela, também, sobre minha observação de que brinquedo, objeto, material nenhum parecia agradá-lo por um tempo suficiente em que conseguíssemos entrar em uma brincadeira; era tudo muito rápido e parecia, de fato, não fazer sentido para ele. Novamente ela deu a explicação, que também me pareceu muito plausível, de que na terapia comportamental, tudo e qualquer coisa que ele pegasse e demonstrasse algum interesse maior era retirado para virar reforçador. Isto é, se ele gostasse de uma bolinha, rapidamente alguém pegaria essa bolinha, solicitaria um comportamento específico para que, então, como reforço pelo comportamento, ele pudesse acessá-la novamente. Pelo relato da mãe, quando Otávio era menor, tinha muitos interesses, mas com o passar do tratamento, foi se distanciando de todos.

De fato, o limiar de tolerância de Otávio para qualquer solicitação nossa era bem baixo, ele logo chorava ou reclamava. A impressão que dava é de que ele não aguentava mais ser requisitado em coisas que lhe eram difíceis, ou que de que imediato soavam para ele como um desafio.

Apesar de sorridente e amoroso, eu precisava criar um vínculo com Otávio para podermos avançar no trabalho, para que eu pudesse também colocar para ele esses desafios sem 
que ele recusasse de imediato. Isto é, eu precisava fazer com que ele quisesse fazer coisas que não estava habituado, e confiasse em mim como sua parceira para tanto.

Comecei, então, com brincadeiras mais sensoriais, já que ele parecia estar familiarizado e se interessar. Também aprendi com ele o que lhe era possível e prazeroso sensorialmente, e o que o desagradava. Os dois primeiros meses foram de muita experimentação, tentativas, acertos e erros. Quando algo não lhe agradava (nesse momento inicial, tinta, por exemplo), fazia questão de dizer que eu tinha entendido o empurrar dele, ou sua expressão facial, como algo ruim, que ele não gostaria de continuar explorando, e parávamos. Quando algo era sentido como muito gostoso e divertido, também contava para ele minha percepção e tentava, após um tempo de exploração livre, dar algum sentido, a partir da minha observação sobre o movimento dele com o material (como a caixa com bolinhas de gel, que virou, semanas depois, uma piscina para a família da Peppa Pig).

Nesse início, também, estabeleci com ele alguns combinados: quando não quisesse mais algo, iria colocar na mesa sem jogar. E tais objetos ficariam onde ele havia deixado para que, se quisesse, em outro momento, pudesse retomar no lugar em que havia deixado. Fiz esse combinado porque assim como as coisas eram jogadas no chão, elas pareciam sumir com esse gesto, e reaparecer após um casual (pelo menos para mim parecia ser) esbarrão.

Como combinei com ele? Pegando o que ele jogava no chão, mostrando para ele que colocaria na mesa, e dizendo que quando a gente coloca na mesa a gente pode pegar de novo, depois, se quiser, porque a gente sabe onde está. As primeiras vezes eu fiz sozinha, depois, passei a pedir que ele pegasse o objeto e me ajudasse a colocar na mesa, e depois ele mesmo colocava direto na mesa. Recebi relatos de sua mãe e da escola de que ele estava fazendo do mesmo modo nesses outros ambientes.

Sobre ele não querer sentar nesse início: tudo bem. Brincamos e exploramos muitos materiais em pé, caminhando. $\mathrm{O}$ foco era a nossa relação e o que ele podia compreender e aprender da forma que lhe fosse possível. Mesmo assim, deixava sempre mais de uma cadeira disponível, em locais diferentes da sala, caso ele quisesse se sentar. E aos poucos esse sentar foi sendo incorporado... O caminhar incessante e o esparramar-se no chão, foram dando espaço para o sentar na cadeira e sentar no chão.

Ainda nos primeiros meses de atendimento, Tatá estava gostando de rasgar papéis, qualquer um que encontrasse, de notas de dinheiro a folhas de livros, sem distinção. Sua família estava muito preocupada com os "estragos", e a escola também (afinal, foram rasgadas folhas de agendas dos amigos, lista de presença, entre outros materiais). Introduzi, na sessão com ele, 
livros. Histórias curtas, contadas por mim com muito entusiasmo, com personagens de brinquedo, e tínhamos que virar as páginas juntos.

O primeiro livro que levei tinha as folhas de um papel mais fino, e a primeira coisa que Otávio tentou fazer foi rasgar a capa. Segurei seu movimento, disse que não iríamos rasgar, pois era um livro, e ensinei ele a virar a página, a folhear. Deixei que ele fizesse sem minha ajuda em alguns momentos, e ele gostou! Foi uma tentativa de minha parte, uma aposta em algo que parecia puramente sensorial para algo com algum sentido mais coletivo e social, que envolvesse também, de certa forma, um movimento com as mãos. Felizmente, pareceu fazer sentido também para ele.

Tatá passou a gostar de ouvir as histórias que eu levava, e gentilmente virava as folhas. $\mathrm{Na}$ escola, isso se repetiu, e todos tiveram que se conter, em um primeiro momento, ao vê-lo com um livro na mão! Nada de chamar sua atenção ou dizer que não podia rasgar. Agora ele folheava. Ou melhor: lia o livro!

Com a introdução dos livros e a permanência de algum material sensorial em todas as sessões, caminhos outros foram se abrindo para nós: brincar com as personagens da história que líamos (mesmo que para ele, nesse momento, isso significasse morder o boneco, ou escondê-lo na geleca); fazer de conta que a massinha era comida e dar para os fantoches comerem; transformar a caixa de bolas de gel azul em uma piscina (em que cabia inclusive Otávio, em pé, com os pés afundados!); pintar com giz pastel uma imagem da história; reproduzir uma cena de um vídeo musical do Mundo Bita com brinquedos; brincar com o corpo, principalmente com os pés, através de músicas com o tema; entre outros.

Esses caminhos, sempre pela brincadeira e pela via do prazer, fizeram, aos poucos (em seis meses de atendimento, aproximadamente), com que Otávio ficasse mais tranquilo nas sessões, sentasse, não se recusasse a descobrir coisas novas, se arriscasse em novas brincadeiras, aprendesse outras formas de brincar (como com os blocos, por exemplo, fazendo encaixes), explorasse outros materiais, e, principalmente, retomasse seu interesse por objetos, brincadeiras e personagens.

Ainda assim, quando uma situação nova lhe é apresentada, ele observa bastante, sem tentar imitar ou interagir, e depois de um tempo, se arrisca a repeti-la. Consegue, a faz conforme o modelo, e depois não mais a repete. Dando-nos a impressão de que o esforço foi tão grande para alcançar o objetivo, que ele entende que a "missão foi cumprida", e aí não se arrisca mais a tentar novamente! 
Em oito meses de terapia, Otávio (com quatro anos e sete meses) estava fazendo contato visual com uma frequência maior e conseguindo integrar vocalizações aos gestos e olhar. Passou a pedir ajuda para manusear materiais (devido a dificuldade motora) ou para repetir uma brincadeira física, olhando para nós e nos guiando pela mão; e passou a compartilhar expressões faciais fazendo-as e dirigindo seu rosto para o nosso rosto.

Em um ano e cinco meses de terapia, Otávio (com cinco anos e quatro meses) passou a responder pelo nome assim que chamado; a identificar partes de seu corpo e mostrar quando está com dor; a participar de brincadeiras simples que envolvam troca de turno (jogar uma bola de um para outro, alternar para colocar as peças em um tablado, entre outras); a solicitar brincadeira com fantoche; a imitar ações simples com objetos representacionais; a solicitar objetos fora de seu alcance direcionando sua mão, fazendo contato visual e vocalizando; a procurar na mala que levo para sua terapia os materiais de seu interesse; a dar objetos fazendo contato visual com propósito de obter ajuda; a acompanhar nosso olhar para algo de interesse nosso; a falar em alguns momentos poucas palavras, mas de forma contextualizada e apropriada (a saber: mamãe, não, água, pouquinho, bom dia, pega).

Em relação às minhas orientações à sua acompanhante terapêutica na escola: acontecem desde o início do trabalho com o Tatá, e, assim como na terapia, foi feita uma observação inicial para identificarmos sua melhor forma de aprender, focar e se concentrar e, a partir daí, junto com sua professora, foram estabelecidos os conteúdos pedagógicos. Começamos com a apresentação e posterior discriminação das cores, seguimos, então, com as formas, e delas passamos para as vogais. Inicialmente foram apresentadas apenas as vogais, e atualmente ele está aprendendo os encontros vocálicos.

Não só no aspecto pedagógico, mas também no social tivemos progressos na escola: Tatá tem conseguido permanecer sentado por mais tempo na roda com os amigos, seus colegas de turma têm o procurado para brincar de bater as palmas das mãos e pular de mãos dadas, seus colegas gostam de ajudá-lo em qualquer tipo de tarefa (chegar até o refeitório sem parar no parque, não fugir de determinado espaço, pegar algo em que ele esteja demonstrando interesse), tanto os colegas como Tatá têm trocado muitos abraços de forma espontânea.

Por não acompanhar o mesmo caminho pedagógico de seus colegas, e pela dificuldade de concentração para realizar as atividades com os amigos por perto, a escola disponibilizou uma sala menor, ao lado da sala de sua turma, para que Otávio fizesse suas atividades pedagógicas específicas ali. Em todos os outros momentos, Tatá segue com o grupo, brincando, 
participando, frequentando as diferentes aulas com especialistas (música, educação física, yoga, inglês).

Vamos, agora, às cenas!

\subsubsection{Cenas}

Otávio é exemplar na sua escalada para o entendimento da realidade do mundo em que vive. Uma realidade que lhe cobra precisão e movimentos certeiros para executar uma ação que exige programação para mostrar aos outros e a si que consegue atingir o que quer. Para atingir o que sua intenção lhe pede...

De início, a diferenciação de sentimentos na expressão (a sessão do robô, Cena 1), indicou sua atenção a quem sorria... O espelho entra em jogo, num domínio entre o que se passa com ele e a imagem que provoca. Mais tarde, o boneco que comia e fazia cocô pareceu provocar-lhe os maiores estranhamentos nesse sentido.

Em todos esses movimentos, o que se percebia era um menino para quem o mundo se descontinuava, em parceria preciosa com sua terapeuta, ora na sua concretude e realidade, e ora no faz de conta de uma brincadeira. Otávio, atento e bom aprendiz, dividia olhares entre a boca da terapeuta e o som de pum que ela produzia, e "um boneco que havia comido muito", e precisava fazer cocô: o pum pronunciado era mesmo o pum que o boneco e ela faziam? Importante este momento em que ele confrontava a realidade e a fantasia, incrédulo... Até que o desfecho de um cocô que não era cocô de verdade parece ter causado uma certa aflição e ele decide parar... a brincadeira!

Ao largo disso, a narrativa que a terapeuta lhe apresenta a cada situação das sessões parece ir organizando, silenciosamente, sentidos para as coisas que (lhe) acontecem. Como bom aprendiz, de início olha atento e parece ouvir um amontoado de palavras que precisa "decifrar", mas na sequência, ele age o que filtrou de tantas palavras, em seu entendimento. Segue fazendo e até iniciando e propondo novas interações. Cria até seu texto: "Pe-gaaaa"...

A cena de seu desenho no espelho é emblemática: espelho, corpo, ele é o corpo desenhado no espelho, ele é "eu” e coroa tudo com alegria e carinho. A tristeza pela distração da mãe, que apagou a marca identitária, indica seu envolvimento com a materialidade de seu eu.

Esse mundo cheio de incógnitas vai sendo desvendado na relação terapêutica e ganha espaço para além dela. Tudo isso, cercado de afeto e demonstração de "progressos na 
competência" de comunicação, na medida em que pode dizer o que quer e confraternizar-se com o outro (como a mãe e as pessoas na escola, por exemplo).

E é muito difícil não se sensibilizar diante das mudanças que este pequeno faz, em sua possibilidade de se organizar e organizar o mundo para nele conviver com pessoas, coisas e situações diferentes.

O menino que não olhava (e nem sempre olha para aquilo que faz) mostra ter um registro, um mapeamento, do chão em que pisa, dos desafios que se lhe impõem, das coordenadas das relações que estabelece. São várias as dimensões que passam a constituir sua realidade. Nela, o ganho na mostração de que se dá conta do que está acontecendo à sua volta é uma grande conquista, e isto traz retornos para que ele defina seu lugar no mundo!

\section{Cena 1}

(...) Eu trouxe também o robô que tem várias expressões faciais, e a gente vai girando e vendo, e ele vai fazendo os sons, e em determinado momento, vendo o Tatá sorrir, eu coloquei na expressão de feliz, e disse que o robô, eu e ele estávamos felizes! Ele sorriu novamente e pegou o robô para brincar, passando a mão no rosto, ouvindo os sons diferentes das expressões. Em dois momentos eu falei "Tatá, coloca pra mim na carinha de feliz?" e ele parou com a mão exatamente quando apareceu o robô sorrindo! Fiquei com a nítida impressão de que ele estava sim entendendo minha pergunta e conseguindo responder a ela! (Anotações pessoais, terceiro mês de atendimento, Otávio com 4 anos e 2 meses)

Observe-se a sequência dos atos que envolvem a atenção da terapeuta à atenção de Tatá. Essa é uma valiosa interlocução, cujos efeitos são visivelmente terapêuticos. Imaginação e produção de sentidos e sentimentos: o robô que sente a felicidade pela ação dele de fazer o brinquedo sorrir.

Cena 2

(...) ele foi até a mala e pegou o livro da história do Zezé e colocou no meu colo. Falei pra ele que tinha entendido que ele queria que eu lesse, e comecei. Um pouco antes da cena em que o macaco encontra a mãe, ele falou "mamã”! (Anotações pessoais, quarto mês de atendimento, Otávio com 4 anos e 3 meses)

Ele estava antecipando algo que iria aparecer no livro, que já tinha lido algumas vezes antes! E tudo segue o procedimento de ambos guiado pela atenção e presença àquilo que é feito.

\section{Cena 3}

(...) Aí ele pegou um brinquedo dele, com o qual nunca tínhamos brincado. Então eu falei "Tatá, hoje eu te mostrei dois brinquedos novos, que eu não conhecia. Agora, mostra pra mim esse brinquedo seu. Eu não conheço...”. Ele se sentou ao meu lado, colocou os pés no meu colo, apoiou o brinquedo no colo e ficou me olhando. Eu 
continuei "Como brinca com esse? Tem que apertar? Tem que girar? Como faz?". Ele olhou para mim como que não estava muito entendendo, colocou a mão na testa, como se estivesse pensando, e em seguida apertou o brinquedo para que as bolinhas pulassem. Aí eu falei “Ah! Que legal, Tatá! Entendi! A gente aperta aqui e as bolinhas pulam! Posso tentar agora?", e tirou a mão do brinquedo. Eu apertei, comentei que era legal, e disse que iríamos fazer assim, uma vez ele e outra eu. Fizemos isso umas cinco vezes, e então, logo após a vez dele, eu perguntei "E agora, Tá, é minha vez? O que vc acha?", e ele respondeu com um som semelhante a "não"! Dei risada e falei "É sim! Mas tudo bem se você quiser ir de novo!", ele sorriu e apertou de novo o brinquedo dele. (Anotações pessoais, 3 meses de atendimento, Otávio com 4 anos e 3 meses)

Observa-se aqui uma sequência de troca de sentidos por palavras e gestos. O jogo de expectativas sobre a ação do outro é dado e aprendido no contexto desta sessão. A terapeuta abre o jogo com sua narrativa sobre ele estar propondo com um novo brinquedo que ela não conhecia e que ele deve "explicar", fazendo o brinquedo reagir...

\title{
Cena 4
}

\begin{abstract}
Hoje eu levei pro Tatá alguns blocos de montar grandões. Comecei montando uma torre e chamei ele para me ajudar. Ele passou a segurar na mão a torre e encaixar os blocos conforme eu ia dando para ele. Quando chegamos em 10 blocos, eu falei "Olha, Tá, nossa torre ficou grandona! Olha quantos blocos ela tem!”, e contei do 1 até o 10. Quando eu terminei de contar ele abriu um largo sorriso e foi com a torre na mão até a porta da sala, como quem diz “Abre! Quero mostrar o que eu fiz pra minha mãe!”. Eu disse para ele que imaginava ser isso que ele estava pensando, e que iria abrir a porta. Ele foi direto na direção dela e mostrou a torre! Sua mãe comemorou, disse estar orgulhosa dele, e falou que a torre parecia um troféu! Eu concordei com ela, e disse que era mesmo! Tatá estava vitorioso em montar aquela torre! Ele deu risada, e voltamos para o nosso espaço. Ele cuidou para não desmontar a torre e ficou com ela por perto dele até o final da sessão! (Arquivos pessoais, 5 meses de atendimento, Otávio com 4 anos e 5 meses)
\end{abstract}

A imaginação da terapeuta move também o jogo, e ela narra o que está pensando. $\mathrm{O}$ desenrolar dos gestos/fatos compõem uma cena de comunicação e afetos que se estendem até o fora da sala.

Cena 5

(...) De repente Otávio olhou para a mala, viu o pote de geleca e sentou-se para pegar. Notei que ele abriu o pote, tirou a tampa, mas parecia receoso em colocar a mão para tirá-la. Lembrei, então, que na outra sessão, uma cena semelhante a esta tinha acontecido, mas ele achou que era geleca e quando colocou a mão, percebeu que era massinha e logo tirou fazendo cara de triste. Contei isso para ele, e que por conta do ocorrido na sessão passada, eu havia colocado uma geleca dessa vez na mala, e falei que ele podia confiar e colocar a mão para pegar. Ele sorriu, veio até mim, me deu um abraço, e depois tirou a geleca do pote para brincar, feliz da vida! (Arquivos pessoais, 5 meses de atendimento, Otávio com 4 anos e 5 meses) 
A narrativa baseada na memória da terapeuta sobre expectativas frustradas, faz o discurso da sessão disparar em novos rumos. Dispara o prazer, o afeto e a alegria de brincar...

\title{
Cena 6
}

\begin{abstract}
Quando eu cheguei na casa dele hoje, ele estava com um chocalho nas mãos. Então, eu peguei um microfone de brinquedo que estava na sala e falei que nós iríamos fazer uma bandinha! Peguei também o xilofone, toquei um pouquinho, e falei que era a vez dele começar uma música. Ele ficou me olhando... aí eu disse que ele podia inventar, e inventei uma para demonstrar no xilofone. Em seguida eu passei a baqueta do xilofone pra ele, ele tocou um pouco, depois parou, veio até mim, me deu um beijo e um abraço. Eu falei pra ele que tinha ficado muito feliz por ele ter tocado também! Acho que ele gostou de conseguir tocar e entrar nessa brincadeira conforme meu pedido. (Anotações pessoais, 6 meses de atendimento, Otávio com 4 anos e 6 meses)
\end{abstract}

Acrescente-se ao que já se destacou, a possibilidade de esperar a ação de Tatá no sentido do que lhe foi solicitado. E ele "agradece" com seu carinho, beijo e abraço.

\section{Cena 7}

(...) Quando ele foi para a cama elástica ele estava com duas metades da bola de encaixe, e não estava conseguindo juntá-las para formar a bola. Aí eu peguei outras duas e mostrei pra ele, que ele poderia encostar no peito, as partes, e juntar as mãos, com as metades. Ele ficou observando e fez igual. Depois de montar, eu falei "Agora você quer me dar a bola?" e ele não respondeu, nem com gestos nem com vocalização. Então eu falei "Você quer trocar de bola comigo, agora?" e em seguida ele estendeu a bola dele para mim e nós trocamos. Ele está conseguindo entender e se comunicar muito melhor, ou com gestos, ou dizendo não, enfim... E ele está tentando imitar e repetir o movimento como tentativa para alcançar o objetivo. Antes ele tentava uma vez e logo desistia, agora ele não consegue na primeira tentativa e segue tentando até conseguir! (Anotações pessoais, 7 meses de atendimento, Otávio com 4 anos e 7 meses)

\section{E viva o Tatá, em sua busca de entendimento!}

\section{Cena 8}

Hoje eu resolvi fazer uma tentativa e levei pra ele a casinha da Peppa Pig com as personagens. Assim que mostrei para ele, disse que iríamos fazer uma brincadeira diferente para ver se ele gostava e se fazia sentido. Ele logo sorriu. Eu montei a casa, coloquei a Peppa na banheira dizendo que ela ia tomar banho, ele pegou a escada e ficou segurando, meio olhando, parecendo tentar entender tudo que estava ali. Aí eu falei que a Mamãe Pig ia subir na escada para pedir pra Peppa sair do banho, e enquanto ele segurava a escada, eu fiz a Mamãe subir por ela, e chamá-la. Nisso, ele mesmo pegou e tirou a Peppa da banheira! Eu fiquei muito feliz. E em seguida ele se afastou, e eu imaginei que ele não quisesse mais continuar a brincadeira. Mesmo assim, resolvi insistir um pouco, e continuei a história, fazendo o Papai Pig chamar a Peppa e o George para irem dormir, e mostrei que cada um deles iria dormir na sua cama com seu bichinho de pelúcia. Otávio rapidamente segurou as caminhas, e colocou os personagens para dormir!!! Eu disse, então, que no dia seguinte eles acordaram e foram passear de trem com o Vovô Pig, e coloquei os personagens no trem. Ele ficou olhando eu dar uma volta com o trem, e quando voltaram para casa, eu falei que eles chegaram com fome, e a Mamãe Pig tinha separado um almoço! 
Enquanto eu pensava o que poderia pegar para fazer de conta que era a comidinha, Tatá foi até a mala, pegou os cupcakes de Lego (que tínhamos montado em outra sessão, mas que continuavam montados), colocou um em cima da mesa dele, e outro perto da Peppa. Depois, pegou um ovo de encaixe e colocou em cima da mesa da Peppa! Eu disse que ele tinha tido uma ótima ideia, e que agora todos poderiam comer! E aí ele aproximou a Peppa do ovo! Quanto orgulho desse garoto! (Anotações pessoais, 8 meses de atendimento, Otávio com 4 anos e 8 meses)

O reconhecimento de personagens familiares, a iniciativa de participar e complementar a brincadeira, a busca por um objeto que completasse a nossa cena (iniciada por mim, mas claramente seguida por ele) e fizesse sentido, o controle motor para colocar o ovo na mesa e, assim, concluir sua cena também... Tatá, em diferentes níveis, estava mostrando até onde ia sua compreensão, colaboração, interação.

\section{Cena 9}

(...) Nesse mesmo dia, ele pegou 3 bloquinhos de madeira, de tamanhos diferentes, e os empilhou. Primeira vez que ele fez isso sem que houvesse um encaixe entre os blocos, e de forma espontânea. Ficou olhando ao redor, como se procurasse mais algum bloco, ou alguma outra coisa, até que viu a miniatura da televisão da Peppa, pegou e colocou no topo de sua torre. Agora sim ela estava completa! (Anotações pessoais, 8 meses de atendimento, Otávio com 4 anos e 8 meses)

Aqui, temos mais alguns passos de Tatá sobre o mundo do brincar: empilhar sem encaixe, baseando-se na forma, tamanho, e imagem mental de uma torre; busca por objetos que completassem, possivelmente, a imagem que ele mesmo tinha formado em sua cabeça sobre como deveria ficar aquela torre; encontro e colocação da peça que viria a finalizar sua construção.

\section{Cena 10}

Hoje a sessão foi bem diferente, acho que Tatá estava estranhando a mudança de casa, nosso novo espaço de terapia, então ele estava observando tudo, não conseguia muito entrar em nenhuma brincadeira comigo... Exceto a dos cubos de encaixe. Eu propus que a gente montasse uma torre, e comecei colocando um como base. Pedi que ele colocasse outro, e ele colocou, e fomos assim alternando. A partir do quarto cubo ele começou a esperar que eu desse para ele o que ele deveria por, por conta do tamanho, imagino eu. Então, comecei a separar dois, um que era o correto e outro bem pequeno, e perguntar para ele qual deles ele achava que ficaria melhor na nossa torre, o pequeno ou o grande ( sem indicar qual era qual, e ora deixando o pequeno na mão direita, ora deixando o grande na mão direita). Ele olhava rapidamente para ambos e em seguida escolhia o correto e colocava. Quando terminamos ele sorriu, deixou-a montada por um tempo, e depois derrubou com gosto! (Anotações pessoais, 9 meses de atendimento, Otávio com 4 anos e 9 meses) 
Esta cena nos mostra que sim, Tatá é sensível aos seus arredores e ao contexto. E, quando em confiança, consegue relacionar-se nesses novos espaços e situações, e até mesmo aceitar pequenos desafios cognitivos como forma de interação.

\title{
Cena 11
}

\begin{abstract}
Hoje, quando fui conversar com a Bianca, psicóloga que acompanha o Otávio na escola, a professora dele sentou com as crianças em roda e começou a conversar sobre o alfabeto, e explicar quais letras eram as vogais que Tatá está aprendendo. Enquanto nós conversávamos, Tatá estava em pé, andando pela sala, mas quando sua professora começou a falar das vogais, ele rapidamente olhou para nós, e sentou-se no meio da roda, espontaneamente. Sentou-se feliz, animado, sorridente. Acredito eu que ele tenha se sentido realmente fazendo parte do grupo, uma vez que agora seu aprendizado pedagógico tinha alcançado o de sua turma, de certa forma. A auxiliar da professora começou a distribuir os cadernos das crianças, ele ficou olhando, como quem procura o dele, foi até a mesa, continua em busca do seu, que estava guardado em outro local. Comentei que ele devia estar procurando seu caderno, e sua AT deu para ele. Ele sentou na mesa, nós demos o giz, e ele fez um lindo rabisco livre. Otávio estava ali como seus amigos, com seus amigos. (Anotações pessoais, 10 meses de atendimento, Otávio com 4 anos e 10 meses)
\end{abstract}

Temos aqui um exemplo da atenção de Tatá ao que lhe faz sentido; a participação, atenção e colaboração são espontâneas, e a alegria aparece como a consequência mais natural disso tudo... Otávio fala por si e de si...

\section{Cena 12}

Hoje eu levei um boneco para brincar com o Otávio, que tem um buraco na boca em que podemos colocar massinha e depois ele "faz cocô". Eu apresentei o boneco para ele, disse que era um boneco, que nós iríamos dar comidinha para ele, separei a massinha, e fiz uma comidinha na forminha e dei. Tatá ficou de longe olhando, meio ressabiado, como quem reconhece que é um brinquedo, um boneco inanimado, e, ao mesmo tempo, tem suas dúvidas sobre isso. Eu aproximei dele, disse que era um boneco, de brincadeira, ele colocou a mão na cabeça do boneco, e sentou no chão. Então eu preparei outra comidinha de massinha e falei que o boneco estava com fome, se ele poderia me ajudar a alimentá-lo. Rapidamente ele deu, e depois deu mais comidinha em outras vezes, parecendo gostar de conseguir, de fato, colocar a massinha na boca do boneco e esta sumir! Como ele vinha há alguns dias bastante constipado, mostrei para ele uma miniatura de privada e disse que o boneco tinha comido demais, e estava com a barriga muito cheia. Levantei a blusa do boneco, e fiz uma massagem, como a que sua mãe faz nele nessas ocasiões. Ele sorriu e fez alguns sons. Então eu fiz uns barulhos de pum e falei "Tá, você está ouvindo? Ele está soltando pum! Acho que logo logo ele precisará correr pro banheiro!’. Ele olhava para minha boca fazendo o som, olhava para o boneco, como que tentando entender tudo aquilo. Continuei a brincadeira. Mostrei a privada e falei "Acho que agora ele pode sentar na privada pra fazer cocô! Vamos tentar?". Otávio pegou a privada, deu a descarga, e então eu coloquei o boneco sentado e disse "Vamos lá, faz força pro seu cocô sair!!!”, e Tatá deu risada... Talvez tenha lembrado das pessoas falando isso para ele, talvez tenha se identificado com o boneco... Quando eu tirei o boneco do vaso e Tatá viu que tinha o desenho de um cocô lá dentro, ele olhou pra mim rapidamente, e logo começou a tentar tirar o cocô da privada, batendo sua mão no plástico que "protege" o desenho. Eu expliquei para ele que era apenas um brinquedo, que aquilo que ele estava vendo era um desenho, uma representação de algo que acontece de 
verdade, mas que não era de verdade. Ele me olhou, colocou o dedo indicador próximo ao olho, como quem está pensando, colocou a privadinha no chão e levantou-se. Fim da brincadeira. (Anotações pessoais, 1 ano e 3 meses de atendimento, Otávio com 5 anos e 3 meses)

Aqui, uma verdadeira "dissonância cognitiva" estabeleceu-se: realidade?; brincadeira?; cocô de verdade?; cocô desenhado?; ele?; o boneco?. Se não der para resolver melhor tudo isso, interrompe-se a brincadeira e ponto! Viraremos a página!

Cena 13

(...) Eu levei também o livro Eu, da Janaína Tokitaka, e comecei a ler para ele. A cada vez que aparecia a palavra "eu", eu batia de leve a mão no meu peito, e colocava a mão dele no peito dele. Fiz isso algumas vezes, e depois, mais de uma vez, ele mesmo colocou a mão no peito e correu para o espelho da sala para se ver! Eu não falei para ele ir ao espelho, ele fez isso espontaneamente (talvez lembrando da semana passada em que brincamos de fazer expressões no espelho e eu fiz algumas vezes o "eu", da mesma forma como fiz hoje). (Anotações pessoais, 1 ano e 4 meses de atendimento, Otávio com 5 anos e 4 meses)

\author{
E Otávio cresce a olhos vistos, em seus movimentos por entre e junto com o \\ entorno/contexto concreto e imaginário...
}

Cena 14

Na semana passada nós continuamos a brincadeira do "eu", e eu desenhei o Tá no
espelho de sua casa. No começo eu achei que ia ser difícil ele ficar parado no espelho
para eu fazer seu contorno, porque lembrava de ter tentado fazer isso anteriormente e
ele não tinha conseguido ficar parado, nem saído e depois voltado para eu terminar o
desenho. Mas, não custa tentar... o menino cresceu, não é mesmo?! Que bom que
tentei! Ele deixou, e ficou MUITO feliz ao ver seu contorno no espelho. Deu beijo em
sua imagem e tudo! Eu escrevi a palavra "eu", aproveitando a aprendizagem dos
encontros vocálicos da escola, e ele sorria, colocava a mão na palavra, nele, no
espelho, uma alegria só. A sessão de hoje veio depois do feriado, e assim que eu
cheguei sua mãe me contou que algo muito curioso havia acontecido: no dia anterior
ela foi limpar o nosso espaço de terapia, e o Tá estava lá com ela. Ela viu o desenho
no espelho, comentou com ele, e depois pegou um pano para passar e apagar, pois
imaginou que poderíamos fazer de novo, e brincar outras vezes. Tatá, quando viu,
ficou nervoso: começou a pular, reclamar, e até chorou. Ela entendeu que era por conta
de estar limpando o espelho, disse que pediu desculpa para ele, e avisou que me falaria
para que eu desenhasse ele de novo. Então, na sessão de hoje, essa foi uma das coisas
que fizemos... (Anotações pessoais, 1 ano e 4 meses de atendimento, Otávio com 5
anos e 4 meses)

Com o tempo, a confiança de Tatá na parceria e a aposta da terapeuta nas possibilidades de Otávio produzir e compreender novos sentidos, mostra-se fundamental para: tanto Tatá demonstrar o que pode, consegue, compreende e sente, como para a terapeuta perceber o quanto ele cresceu e mudou nesse tempo de atendimento... e sua mãe também! 
Cena 15

Otávio está numa fase em que pega a massinha e estica e pressiona ela com força
sobre qualquer superfície que encontra. Hoje na sessão, ele estava com uma geleca
quando começou a fazer isso na parede. Falei para ele que não poderia fazer na parede,
pois era difícil de tirar, e pedi pra ele pegar o que tinha sobrado da geleca ali. Isso se
repetiu três vezes, até que ele olhou para a estante e viu que tinha um pote de massinha.
Empurrou a cadeira e tentou alcançar, mas ainda estava distante. Então, ele não teve
dúvida: olhou para mim, apontou para a massinha, olhou para mim novamente e falou
"pe-gaaa". Claro que eu peguei! E super comemorei o fato de ele ter usado uma
palavra para dizer o que queria, junto com o apontar, o olhar e tudo o mais... ele
percebeu minha alegria, começou a dar vários pulinhos sorrindo, e depois, em um
momento em que deixou cair a massinha ao lado da cadeira, olhou para onde ela caiu,
olhou para mim, puxou minha mão e falou "pegaaaaa"! (Anotações pessoais, 1 ano e
5 meses de atendimento, Otávio com 5 anos e 5 meses)

Uma palavra coroa a sequência de raciocínios e cálculos de pensamento mostrados na organização de ações para atingir um fim... É surpreendente!

Otávio evoluiu muito. Quem não o conhece como nós (eu, outros terapeutas e família), pode dizer que não mudou nada, porque as pessoas tendem a considerar apenas a fala. Mas para quem o acompanha assim de perto, com os objetivos de trabalho na cabeça, e tendo como guia desses objetivos e das nossas ações Otávio, o menino, há muito a ser reconhecido como evolução.

Os passos e progressos podem ser pequenos se compararmos com o de outras crianças (o que não fazemos, todo o tempo de trabalho com ele), mas comparando com o próprio Otávio... que construção imensa conseguimos realizar juntos! E seguimos. 


\section{DISCUSSÃO}

Antes de tudo, cabe, aqui, um comentário sobre a maneira como descrevi o atendimento a essas crianças, no capítulo 5. O leitor pode ter considerado excessiva, a reiterada afirmação de que o método era o da AID e que se procedia à análise e não à interpretação. Ora, deve-se lembrar que a presente Tese prossegue com a discussão das questões levantadas pela Dissertação de Mestrado. E a ideia foi a de apresentar uma alternativa para a clínica do autismo, que se marcasse pela atenção e observação das crianças, com a preocupação em considerar o contexto concreto do dispositivo terapêutico que define lugares para os dois atores em cena, cabendo a um deles o lugar de analista e, ao outro, o de criança/paciente, cada um deles, um lugar de enunciação. O jogo empírico, a experiência concreta, dessa relação é a ocasião de produção de sentidos para o que faz, fala, a criança. Nenhuma teoria consolidada, sobre razões inconscientes de suas atitudes, deveria antecipar, na fala/compreensão do analista, as razões daquela criança em especial com que estamos interagindo. Também, nenhum procedimento pré-elaborado, de observação e controle, deveria se impor como determinante dos seus movimentos e comportamentos nas sessões, com direito a generalizações para o ambiente cotidiano de sua vida. Reconheça-se na primeira situação o modo como mostram pensar e agir os psicanalistas que entrevistei no Mestrado. Na segunda, o fazer dos analistas do comportamento (ABA). Devidamente fundamentado, naquela ocasião, o método da Análise Institucional do Discurso foi a estratégia para pensar e tratar dessas duas modalidades terapêuticas que dominam, o cenário dos tratamentos ao autismo neste e naquele momento. Herdeiros de instituições importantes e dominantes, os analistas infantis têm se dividido, inclusive no cenário internacional, com propostas que divergem radicalmente. E, não menos importante, com a estratégia analítica da AID, pudemos apontar que, em ambos, a criança ocupa um estranho lugar de quem tem sua singularidade obscurecida, ou mesmo desperdiçada, em função da observação e da escuta de tudo o que já está previsto no âmbito das teorias e/ou dos procedimentos técnico-metodológicos.

$\mathrm{O}$ analista do discurso entra em cena, em seu trabalho, como quem porta alguns poucos conceitos e prescrições de acompanhamento do que acontece numa sessão. Sobre esse caráter conceitual minimalista e sobre os princípios gerais de uma análise descritiva, muito já expusemos neste e no trabalho anterior (Mestrado). No momento, cabe apenas voltar a dizer, que o alvo desta Tese de Doutorado é avançar no sentido de fazer uma proposta de atendimento que se paute pela estratégia de pensar que considere o lugar discursivo que a criança tem em 
seu tratamento e que esse lugar pode se mostrar e exercer no brincar/imaginar/agir, desde que eu, como terapeuta, considere como discurso, o próprio ato de brincar, na medida em que isso for possível para ela. É nesse âmbito que se construirão sentidos e destinos da terapia.

Vamos retomar, agora, a linha mestra do estudo e de sua escrita.

Logo no início, é apresentado ao leitor o caminho que seguiríamos: tomar a relação da criança com o terapeuta e com o brincar como discurso em análise. Mostrou-se na pesquisa de mestrado desta autora, a necessidade de uma abordagem terapêutica em que a criança atendida tivesse um lugar de enunciação, o que isso significa, e no que essa ideia se sustenta na estratégia metodológica da AID.

Em seguida, apresentamos ao leitor como ocorre o desenvolvimento do brincar em uma criança considerada neurologicamente típica, para que ela comece a adentrar em nosso universo de linguagem, conceitos, ideias. Escolhemos, então, dar foco ao modo de análise de Brunner com relação ao brincar, por conta do caráter descritivo das cenas que apresenta. Mostramos, também, por seu texto, a relação e interação do bebê com o adulto, que, em muito, tem registro semelhante ao que fazemos: observar a criança; dar espaço para que ela se comunique e interaja, de forma verbal ou não verbal; permitir que ela oriente o rumo da brincadeira conforme suas próprias possibilidades; criar junto com ela situações desafiadoras para cada etapa de seu processo; reconhecer que há, nesta cena, duas pessoas, como dois enunciadores, partilhando e construindo o contexto.

Apresentamos, com outros autores, o lugar do adulto numa brincadeira com uma criança, que também vai ao encontro de nossa forma de pensar, como por exemplo, dar suporte à brincadeira e ser responsivo aos sinais de interação da criança. Essas posturas, aliadas a uma atenção constante ao que está sendo produzido ali, na relação, é o que possibilita que ela ocupe o que nós chamamos de lugar discursivo. Trata-se aqui de uma postura ética. A técnica e o fundamento teórico estão a serviço dela.

Na sequência, entramos na definição médica de autismo e suas características, para familiarizar o leitor quanto ao quadro diagnóstico das crianças atendidas, e suas formas de avaliação. E, uma vez adentrada a questão diagnóstica, apresentamos um pesquisador, BaronCohen, e seus achados sobre a teoria da mente e o autismo.

Seguimos explicitando o método e como pensamos com ele as cenas e situações concretas de nosso trabalho com as crianças com autismo. 
Demonstramos, por fim, com os atendimentos apresentados e as análises de suas cenas, como a estratégia da Análise Institucional do discurso nesse contexto específico, move efeitos terapêuticos.

No decorrer de todo esse trabalho, algumas discussões foram trazidas no confronto com os atendimentos aqui expostos, e delas foram pensadas algumas das relações importantes que estabelecemos, ao longo dos anos, no trabalho com as crianças com o diagnóstico de autismo pela e na AID.

A primeira delas refere-se à singularidade das condições de atendimento. Só podemos considerar singularidade porque se trata de uma análise, e não de uma interpretação que tome uma teoria como referência para pensar uma cena. Cada um dos atendimentos é único, não há um igual ao outro, embora a terapeuta seja a mesma. Isso acontece porque a terapeuta, em ato, potencializa o lugar da criança e, com isso, abre espaço para descobrir como ela se comunica, como ela se mostra, e também porque a terapeuta constrói a sessão a reboque das ações de seu parceiro-paciente. Ela é coprodutora da singularidade, dos sentidos forjados no e pelo contexto da própria terapia como uma relação concreta. Ao adulto cabe a compreensão da necessidade de atenção e observação do brincar da criança como o contraponto.

Por que distinguimos esse trabalho daquele que habitualmente se produz como interpretação? Porque consideramos (e pudemos confirmar no estudo de Mestrado) que as interpretações costumam confrontar o que a criança faz, com o que, por uma ou outra teoria, se entende/explica ser o que ela faz. É exatamente aí que constatamos em nosso estudo anterior: a teoria "antecipa" o acontecimento-ato do discurso da sessão. É exatamente aí que não se confere até as últimas consequências, um lugar de enunciação a quem ocupa o lugar de paciente, na clínica dessas crianças.

Um segundo aspecto relevante a resgatar neste momento da Discussão é o que diz respeito à importância de a criança dizer de sua história. Apoiamos a apresentação do Método (capítulo 4) em um relato muito especial de um atendimento e em seguida enfatizamos, no dizer de Guirado, o valor subjetivo para as crianças (no caso, em condição de abrigo social) da narrativa da própria história, de onde, podemos prosseguir argumentando, esses pequenos retiram seu direito a poder contá-la sobretudo no contexto clínico. Pois bem. Essa foi a regra de prudência (Foucault,1976/1985) que pautou tanto as terapias quanto os relatos que delas fizemos na forma de cenas, no âmbito deste trabalho.

Um terceiro aspecto a resgatar decorre daí: exercer tal atenção em cada sessão é a condição para que se definam os lugares de adulto e criança. Sobretudo, para que ambos se 
potencializem ao seu modo, ritmo e intensidade, conforme as particularidades das parcerias constituídas nos diferentes contextos do brincar.

A quarta discussão a destacar é em relação ao discurso como acaso e acontecimento. Entender desse modo cada sessão é colocar-se na perspectiva do acaso e acontecimento. Sempre regido por ordenações internas e externas, como diria Foucault, os discursos são controlados em sua dimensão de acaso e acontecimento, em sua possibilidade de produzir uma multiplicidade de efeitos concretos e imaginários, em ato, reverberando as tensões dos movimentos que potencializam (Foucault, 1971/1996). Ora, esse é o caráter surpreendente dos caminhos das cenas que configuramos na clínica, animados pela estratégia de pensamento que adotamos. Essa é a face surpreendentemente singular de cada atendimento.

A quinta é sobre a importância da compreensão da sessão como cena. Pelo modo como relatamos as sessões nesta Tese, pode-se supor que descrevíamos a cenografia (a sessão em si) de modo "fiel" à nossa ação direta. Sim, produzíamos conjuntamente atividades imaginativas, pedagógicas e cognitivas num ir e vir de potencialização das falas e/ou ações dos dois (ou mais) personagens e/ou lugares em cena. Inseríamos o acontecimento e o acaso no próprio ato terapêutico, no próprio fazer da sessão.

E, por fim, um sexto aspecto: aquele que trata da ação do adulto como facilitadora para estabelecimento do contexto para a criança. Corriqueiramente, diz-se que as crianças com autismo são alheias ao seu redor, ao que está acontecendo, como se estivessem em um outro mundo, não compartilhassem do que está acontecendo ali, onde elas estão naquele momento. Onde está a dificuldade de criação desse contexto, Baron-Cohen nos instrumenta a pensar com sua teoria, como vimos anteriormente. Mas, se nos colocarmos na perspectiva daquilo que Maingueneau escreve e que a AID toma como método: para que um contexto seja construído e sustentado, as pessoas precisam regular a relação entre elas quanto às suas ações e expectativas. Se uma criança não tem essa habilidade de regular a relação com o outro, de cocriar contextos, ela dá a impressão de que está alheia ao mundo que a circunda. Ela passa a mensagem para os demais de que está apenas fisicamente ali. E é exatamente neste ponto que a participação do adulto na relação com a criança torna-se imprescindível para que esse contexto se dê. E se dê de que forma? A partir da própria dificuldade de contexto que essas crianças apresentam...

Quando nós acompanhamos atentamente os movimentos da criança, fundamos com ela lugares de enunciação, abrindo-se espaço para ela enunciar e coconstruir um contexto. E aí, por maiores que sejam suas limitações, ela consegue, na e pela terapia, estar presente para brincar, aceitar ou recusar propostas, interagir. 


\section{CONSIDERAÇÕES FINAIS}

Como dissemos no capítulo anterior, é interessante ver que cada criança aqui apresentada tem uma história diferente, tem dificuldades e competências diferentes, idades variadas, percursos únicos, mas a mesma terapeuta, com o mesmo método. E método, aqui, sendo esse da AID, que possibilita que a terapeuta tenha ações guiadas pelas motivações, histórias, dificuldades e capacidades de cada criança, considerando suas necessidades, reconhecendo atentamente cada movimento, cada interação, cada tentativa.

É o método, tal como investido pela terapeuta, que lhe permite essa liberdade de agir. Um método, que, no meu caso, segue amparado por conceitos de desenvolvimento infantil, do brincar, sobre o diagnóstico de autismo, sobre a teoria da mente.

Trabalho com uma escala de observação? Sim, ela foi aplicada nos atendimentos e pode servir como referência do efeito do tratamento em determinada criança, mas só. Não é ela quem dita o que tem que ser feito e nem como deve ser feito.

Mesmo o método, entendido como um conjunto de recursos técnicos e passos regrados para obtenção de comportamentos, não dita. O método, tal como explicitamos aqui, é um modo de pensar. Nas situações de atendimento à crianças, é um modo de pensar a criança partindo dela, considerando-a. Mesmo que não fale, mesmo que não siga instruções, mesmo que fuja ao desenvolvimento típico e esperado para idade.

Nessa perspectiva, o trabalho implica discurso como ato e o brincar como discurso da criança. O discurso da criança como o brincar. O brincar como discurso-ato. Se o que as crianças com autismo fazem pode ou não ser considerado um brincar, conforme uma descrição acadêmica? Elas fazem o que podem. Elas fazem o que conseguem. Elas brincam conforme o que lhe é possível fazer. Otávio corre e busca sensações, Henrique observa carrinhos, Ricardo vê letras em tudo, Gustavo quer livros, Lola lê, Thiago é passarinho.

Se ficássemos olhando onde elas escapam da norma e nos preocupando em fazê-las pertencer a esta custe o que custar, correríamos o grande risco de perdermos essas crianças (como vimos em outras abordagens). Isso não significa que não haja um norte, um rumo no tratamento. Mas o que há é, sobretudo, uma criança coartífice desse rumo na sua singularidade. No caso desta tese, uma criança com diagnóstico de autismo.

Há uma atenção observadora do fazer da criança na situação terapêutica: terapeuta acompanha os movimentos de seus pequenos para com a vida, bem como na relação com ela. É isto que faz com que a criança seja a protagonista da cena, de sua história, e não a terapeuta. 
Penso ter conseguido demonstrar nesta Tese como tudo isso, sobretudo esse lugar de protagonista na sua própria terapia conferido à criança, é facultado por esse modo de pensar o trabalho, por esse método, a AID. 


\section{REFERÊNCIAS}

AMERICAN PSYCHIATRIC ASSOCIATION. Diagnostic and statistical manual of mental disorder (DSM-V). Washington, DC: American Psychiatric Association, 2014.

AMORIM, L. AMA, 2011. Acesso em 17 de Janeiro de 2018, disponível em Associação de Amigos do Autista: http://www.ama.org.br/site/diagnostico.html

ARONSON, J., \& GOLOM, C. Preschoolers' understanding of pretense and presumption of congruity between action and representation. Britsh Journal of Developmental Psychology, v.35(16), pp. 1414-1425, 1999.

ASSUMPÇÃO, J., KUCZYNSKI, E., GABRIEL, M., \& ROCCA, C. Escala de Avaliação de Traços Autistas (ATA): validade e confiabilidade de uma escala para a detecção de condutas autistas. Arquivos de Neuropsiquiatria, 57(1), 23-29, 1999.

AULAGNIER, P. Um intérprete em busca de sentido. São Paulo: Escuta, 1990.

BARON-COHEN, S. Are autistic children behaviorists? An examination of their mentalphysical and appearance-reality distinctions. Journal of Autism and Developmental Disorders, v.19, pp. 579-600, 1989.

BARON-COHEN, S. Do people with autism understand what causes emotion? Child Development, v. 62, pp. 385-395, 1991.

BARON-COHEN, S. Mindblindness: An essay on autism and theory of mind. Massashusetts: MIT Press, 1997.

BARON-COHEN, S., ALLEN, J., \& GILLBERG, C. Can autismo be detected at 18 months? The needle, the haystack, and the CHAT. British Journal of Psychiatry, v. 161, s.d.

BARON-COHEN, S., SPITZ, A., \& CROSS, P. Can children with autismo recognize surprise? Cognition and emotion, v.7, pp. 507-516, 1993.

BATES, E., BENIGNI, L., BRETHERTON, I., CAMAIONI, L., \& VOLTERRA, V.

Cognition and communication from 9 to 13 months: correlational findings. Em E. Bates, The emergency of symbols: cognition and communication in infancy. Academic Press, 1979.

BODROVA, E., \& LEONG, D. J. Adult influences on play - The vygotskian approach. Em D. P. Fronberg, \& D. Bergen, Play from birth to twelve - Contexts, perspectives, and meanings (pp. 167-172). New York: Taylor and Francis Group, 2006.

BORGES, J.L. et al. Avaliação neuropsicológica dos transtornos psicológicos na infância. Psico-USF, v.13(1), 2008.

BROOKS, B., SHERMAN, E., \& STRAUSS, E. NEPSY-II: A Developmental Neuropsychological Assessment, Second Edition. Child Neuropsychology, v. 16(1), pp. 80101, 2009. 
BROUGÈRE, G. A criança e a cultura lúdica. Em T. Kishimoto, O brincar e suas teorias (pp. 19-32). São Paulo: Cengage Learning, 2015.

BRUNER, J. Child's Talk - Learning to use language. New York: W.W. Northon \& Company Inc, 1983.

BUTTERWORTH, G. The ontogeny and phylogeny of joint visual attention. Em A. W. (ed), Natural theories of mind. Blackwell, 1991.

CAPOVILLA, A., \& CAPOVILLA, F. Prova de Consciência Sintática (PCS) normatizada e validada para avaliar a habilidade metassintática de escolares de 1a. a 4a. séries do ensino fundamental. São Paulo: Memnon, CNPq, Capes, 2006.

COHEN-BARON, S., LESLIE, A., \& FRITH, U. Does the autistic child have a 'theory of mind'? Cognition, v.21, pp. 37-46, 1985.

ELKONIN, D. Psicologia do jogo. São Paulo: Martins Fontes, 2009.

FIGUEIREDO, V. WISC-III: Escala de Inteligência Wechsler para Crianças - adaptação

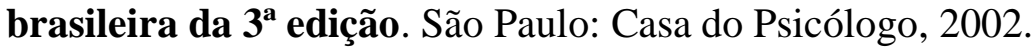

FOUCAULT, M. Arqueologia do Saber. Rio de Janeiro: Ed. Forense, 1969/1997.

FOUCAULT, M. A Ordem do Discurso. São Paulo: Loyola, 1971/1996.

FOUCAULT, M. História da Sexualidade I: A Vontade de Saber. Rio de Janeiro: Graal, 1976/1985.

FOUCAUlT, M. Ditos e Escritos - Ética, Sexualidade e Política (Vol. 5). São Paulo: Forense Universitária, 1984/2004.

FOUCAULT, M. Sujeito e Poder. Em H. Dreyfus, \& P. Rabinow, Michel Foucault: Uma trajetória filosófica para além do estruturalismo e da hermenêutica (pp. 231-249). Rio de Janeiro: Forense Universitária, 1995.

FREUD, S. Construções em análise (1937). Em S. Freud, Moisés e o monoteísmo, Esboço de psicanálise e outros trabalhos (1937-1939) (Vol. XXII, pp. 275-287). Rio de Janeiro: Imago, 1937/2006.

GOLOMB, C., \& KUERSTEN, R. On the transition from pretense play to reality: What are the rules of the game? British Journal of Developmental Psychology, v.14, pp. 321-329, 1996.

GRANT, D., \& BERG, E. Behavioral analysis of degree of reinforcement and ease of shifting to new responses in weigl-type card-sorting problem. Journal of Experimental Psychology, pp. 404-411, 1948.

GRAY, C. The New Social Story Book. Arlington: Future Horizons, 2010. 
GUILHON-ALBUQUERQUE, J. Metáforas da Desordem. Rio de Janeiro: Paz e Terra, 1978.

GUIRADO, L., \& GUIRADO, M. Tratamentos do autismo: a direção do olhar - Uma análise institucional do discurso da psicanálise e da análise do comportamento aplicada. Saarbrücken: Verlag/ Novas Edições Acadêmicas, 2014.

GUIRADO, L., \& GUIRADO, M. A direção do olhar nos tratamentos do autismo. Curitiba: Appris Editora, 2018.

GUIRADO, M. A clínica psicanalítica na sombra do discurso. São Paulo: Casa do Psicólogo, 2000.

GUIRADO, M. Acolhimento em abrigos: o direito à construção de narrativas da própria história. Em J. Moreira, M. Salum, \& R. O. (Orgs), Estatuto da criança e do adolescente: refletindo sobre sujeitos, direitos e responsabilidades (pp. 160-169). Brasília: CFP, 2016.

GUIRADO, M. A análise institucional do discurso. Em M. Guirado, A análise institucional do discurso como analítica da subjetividade (pp. 129-213). Rio de Janeiro: Lumen Juris, 2018.

GUIRADO, M. Análise institucional do discurso como analítica da subjetividade. Rio de Janeiro: Lumen Juris, 2018.

GUIRADO, M. Uma analista do discurso no espectro de tratamentos do autismo. Psicologia USP, 29, 135-145, 2018.

HUERTA, M. e. Application of DSM-V criteria for autism spectrum disorder to three samples of children with DSM-IV diagnosis of pervasive developmental disorders. American Journal of Psychiatry, v.10, pp. 1056-1064, 2012.

INSPIRADOS PELO AUTISMO. Criando um ambiente físico otimizado para pessoas com autismo, 2016. Acesso em 17 de Janeiro de 2018, disponível em Inspirados pelo Autismo: https://www.inspiradospeloautismo.com.br/a-abordagem/a-criacao-do-ambientefisico-otimizado-para-autismo/

INSTITUTO DE BIOLOGIA. Genoma, 2018. Acesso em 17 de Janeiro de 2018, disponível em http://genoma.ib.usp.br/pt-br/servicos/consultas-e-testes-geneticos/doencasatendidas/autismo

KISHIMOTO, T. O brincar e suas teorias. São Paulo: Cengage Learning, 2015.

KÖNNECKE, O. Vai, você consegue! São Paulo: Brinque-Book, 2007.

LEMPERS, J., FLAVELL, E., \& FLAVELL, J. The development in very Young children of tacit knowledge concerning visual perception. Genetic Psychology Monographs, v.95, pp. 3-53, 1977.

LERNER, R., \& (orgs), M. K. Psicanálise com crianças: clínica e pesquisa. São Paulo: Escuta, 2008. 
LORD, C., RUTTER, M., DILAVORE, P., GOTHAM, K., \& BISHOP, S. Autism Diagnostic Observation Schedule, Second Edition (ADOS-2) Manual (Part I): Modules 1-4. Torrance: Western Psychological Services, 2012.

LORD, C., RUTTER, M., DILAVORE, P., GOTHAM, K., \& S.L.BISHOP. Autism Diagnostic Observation Schedule, Second Edition (ADOS-2) Manual (Part II): Toddler Module. Torrance: Western Psychological Services, 2012.

LOSAPIO, M., \& PONDÉ, M. Tradução para o português da escala M-CHAT para rastreamento precoce de autismo. Revista de Psiquiatria do Rio Grande do Sul, v.30(3), pp. 221-229, 2008.

MAGYAR, C., \& PANDOLFI, V. Factor structure evaluation of the childhood autism rating scale. Journal of Autism and Developmental Disorder, v.37, pp. 1787-1794, 2007.

MAINGUENEAU, D. Aula - Sobre o Discurso e a Análise do Discurso. Em M. Guirado, A clínica psicanalítica na sombra do discurso: diálogos com aulas de Dominique Maingueneau (pp. 21-31). São Paulo: Casa do Psicólogo, 2000.

MARTELETO, M., \& PEDROMÔNICO, M. Validade do Inventário de Comportamentos Autisticos (ICA): estudo preliminar. Revista Brasileira de Psiquiatria, v.27(4), pp. 295-301, 2005.

MCPORTLAND, J. e. Sensitivity ans specificity of proposed DSM-V diagnostic criteria for autism spectrum disorder. Journal of the American Academy of Child and Adolescent Psychiatry, v.51(4), pp. 368-383, 2012.

MELLO, C., MIRANDA, M., \& MUSZKAT, M. Neuropsicologia do desenvolvimento. São Paulo: Memnon, 2006.

MOLLOY, C., MURRAY, D., AKERS, R., MITCHELL, T., \& MANNING-COURTNEY, P. Use of the Autism Diagnostic Observation Schedule (ADOS) in a clinical setting. Autism, v.15(2), pp. 143-162, 2011.

NAGY, E. \& MOLNAR, P. Homo imitans or homo provocans? Human imprinting model of neonatal imitation. Infant Behavior \& Development, 27(1), 54-63, 2004.

ORGANIZAÇÃO MUNDIAL DE SAÚDE. Classificação Estatística Internacional de Doenças e Problemas Relacionados à Saúde. 10a rev (Vol. v.1 e 2). São Paulo: Universidade de São Paulo, 1997.

PHILLIPS, W., BARON-COHEN, S., \& RUTTER, M. The role of eye-contact in the detection of goals: evidence from normal toddlers, and children with autism or mental handcap. Developmental and Psychopathology, v.4, pp. 375-383, 1992.

QUINTANA, M. Poesia Completa. Rio de Janeiro: Nova Aguilar, 2005.

SCAIFE, M., \& BRUNER, J. The capacity for joint attention in the infant. Nature, v.253, pp. 265-266, 1975. 
SCHWEBEL, D., ROSEN, C., \& SINGER, J. Preschoolers' pretend play and theory of the mind: The role of jointly-conducted pretense. British Journal of Developmental Psychology, v.253, pp. 333-348, 1999.

SINGER, D., \& SINGER, J. Imaginação e jogos na era eletrônica. Porto Alegre: Artmed, 2007.

STERN, D. The interpersonal world of the infant. London: Karnac Books, 1985.

SUTTON-SMITH, B. The spirit of play. (G. Fein, \& M. Rivkin, Eds.) The young child at play - Reviews of research, v.4, pp. 3-15, 1986.

THE OPTION INSTITUTE. The Son-Rise Progam. 1998-2018. Acesso em 18 de Janeiro de 2018, disponível em Autism Treatment Center of America:

http://www.autismtreatmentcenter.org/contents/about_son-rise/history_of_the_sonrise_program.php

TOKITAKA, J. Eu. São Paulo: Brinque-Book, 2014.

WECHSLER, D. Escala de inteligência Wechsler para crianças. Cubos (WISC-III). São Paulo: Casa do Psicólogo, 2002. 